Portland State University

PDXScholar

TREC Final Reports

Transportation Research and Education Center

(TREC)

$1-2017$

\title{
Trip and Parking Generation at Transit-Oriented Developments
}

\author{
Reid Ewing \\ University of Utah \\ Guang Tian \\ University of Utah \\ Torrey Lyons \\ University of Utah \\ David Proffitt \\ University of Utah \\ Preston Stinger \\ Fehr \& Peers Associates

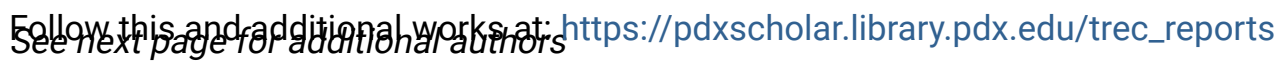 \\ Part of the Urban, Community and Regional Planning Commons, and the Urban Studies and Planning \\ Commons \\ Let us know how access to this document benefits you.
}

\section{Recommended Citation}

Reid Ewing, Guang Tian, Torrey Lyons, and David Proffitt, Preston Stinger, Rachel Weinberger, Ben Kaufman, and Kevin Shivley. Trip and Parking Generation at Transit-Oriented Developments. NITC-RR-767. Portland, OR: Transportation Research and Education Center (TREC), 2017. https://doi.org/10.15760/ trec. 157

This Report is brought to you for free and open access. It has been accepted for inclusion in TREC Final Reports by an authorized administrator of PDXScholar. Please contact us if we can make this document more accessible: pdxscholar@pdx.edu. 


\section{Authors}

Reid Ewing, Guang Tian, Torrey Lyons, David Proffitt, Preston Stinger, Rachel Weinberger, Ben Kaufman, and Kevin Shivley 


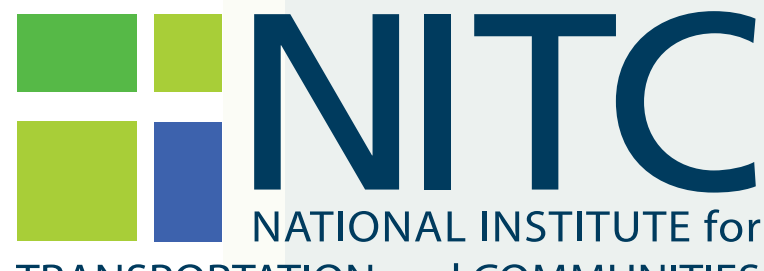

TRANSPORTATION and COMMUNITIES

FINAL REPORT

Trip and Parking Generation at Transit-Oriented Developments

NITC-RR-767 $\quad$ January 2017

NITC is the U.S. Department of Transportation's national university transportation center for livable communities.

H":" TREC 



\title{
TRIP AND PARKING GENERATION AT TRANSIT- ORIENTED DEVELOPMENTS
}

\author{
Final Report
}

NITC-RR-767

\author{
by \\ Reid Ewing, Guang Tian, Torrey Lyons, and David Proffitt \\ College of Architecture + Planning \\ University of Utah \\ Preston Stinger \\ Fehr \& Peers Associates \\ Rachel Weinberger, Ben Kaufman, and Kevin Shivley \\ Nelson/Nygaard Consulting Associates \\ for
}

National Institute for Transportation and Communities (NITC)

P.O. Box 751

Portland, OR 97207
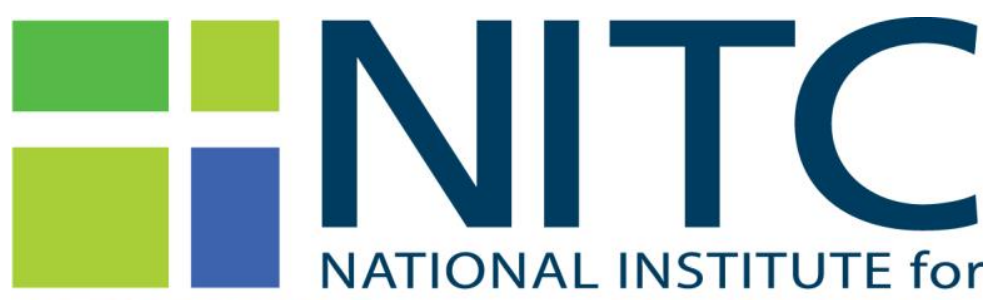

TRANSPORTATION and COMMUNITIES

January 2017 



\begin{tabular}{|c|c|c|c|c|c|}
\hline \multicolumn{6}{|c|}{ Technical Report Documentation Page } \\
\hline $\begin{array}{l}\text { 1. Report No. } \\
\text { NITC-RR-767 }\end{array}$ & \multicolumn{3}{|c|}{ 2. Government Accession No. } & \multicolumn{2}{|c|}{ 3. Recipient's Catalog No. } \\
\hline \multirow{2}{*}{\multicolumn{4}{|c|}{$\begin{array}{l}\text { 4. Title and Subtitle } \\
\text { Trip and Parking Generation at Transit-Oriented Developments }\end{array}$}} & \multicolumn{2}{|c|}{$\begin{array}{l}\text { 5. Report Date } \\
\text { January } 2017\end{array}$} \\
\hline & & & & \multicolumn{2}{|c|}{ 6. Performing Organization Code } \\
\hline \multicolumn{4}{|c|}{$\begin{array}{l}\text { 7. Author(s) } \\
\text { Reid Ewing, Guang Tian, Torrey Lyons, and David Proffitt, College of Architecture + Planning } \\
\text { University of Utah. Preston Stinger, Fehr \& Peers Associates. Rachel Weinberger, Ben Kaufman, } \\
\text { and Kevin Shivley, Nelson/Nygaard Consulting Associates. }\end{array}$} & \multicolumn{2}{|c|}{ 8. Performing Organization Report No. } \\
\hline \multirow{2}{*}{\multicolumn{4}{|c|}{ 9. Performing Organization Name and Address }} & \multicolumn{2}{|c|}{ 10. Work Unit No. (TRAIS) } \\
\hline & & & & \multicolumn{2}{|c|}{ 11. Contract or Grant No. } \\
\hline \multicolumn{4}{|l|}{ 12. Sponsoring Agency Name and Address } & \multicolumn{2}{|c|}{ 13. Type of Report and Period Covered } \\
\hline \multicolumn{4}{|c|}{$\begin{array}{l}\text { National Institute for Transportation and Communities (NITC) } \\
\text { P.O. Box } 751 \\
\text { Portland, Oregon } 97207\end{array}$} & \multicolumn{2}{|c|}{ 14. Sponsoring Agency Code } \\
\hline \multicolumn{6}{|c|}{ 15. Supplementary Notes } \\
\hline \multicolumn{6}{|l|}{ 16. Abstract } \\
\hline \multicolumn{6}{|c|}{$\begin{array}{l}\text { The decision of how best to allocate land around transit stations is a debated topic, with transit officials often opting for park-and-ride lots over } \\
\text { active uses such as multifamily housing, office, and retail organized into transit-oriented developments (TODs). In practice, guidelines for } \\
\text { providing parking and mitigating vehicle trips come mainly from the Institute of Transportation Engineers (ITE) Trip Generation Manual and } \\
\text { the ITE Parking Generation Manual. However, both manuals have well-known shortcomings. The goal of this study is to determine how many } \\
\text { fewer vehicle trips are generated at TODs, and how much less parking is required at TODs, than ITE guidelines would suggest. To answer these } \\
\text { questions, we measure trip and parking generation at five TODs using a methodology that is the most robust published to date. }\end{array}$} \\
\hline \multicolumn{2}{|c|}{$\begin{array}{l}\text { 17. Key Words } \\
\text { TOD, transit, transit-oriented development, parking, trip generation }\end{array}$} & \multicolumn{4}{|c|}{$\begin{array}{l}\text { 18. Distribution Statement } \\
\text { No restrictions. Copies available from NITC: } \\
\text { www.nitc.us }\end{array}$} \\
\hline 19. Security Classification (of this report) & 20. Security Classif & page) & $21 . \mathrm{N}$ & of Pages & 22. Price \\
\hline Unclassified & Unclassified & & 1 & & \\
\hline
\end{tabular}




\section{ACKNOWLEDGEMENTS}

This project was funded by the National Institute for Transportation and Communities (NITC).

\section{DISCLAIMER}

The contents of this report reflect the views of the authors, who are solely responsible for the facts and the accuracy of the material and information presented herein. This document is disseminated under the sponsorship of the U.S. Department of Transportation University Transportation Centers Program [and other SPONSOR/PARTNER] in the interest of information exchange. The U.S. Government [and other SPONSOR/PARTNER] assumes no liability for the contents or use thereof. The contents do not necessarily reflect the official views of the U.S. Government [and other SPONSOR/PARTNER]. This report does not constitute a standard, specification, or regulation. 


\section{Preface}

This study was funded primarily by the National Institute of Transportation and Communities, a University Transportation Center based at Portland State University. Funding was also provided by the Utah Transit Authority, Utah Department of Transportation, Wasatch Front Regional Council (the Salt Lake City MPO), and Mountainland Association of Governments (the Provo-Orem MPO).

In addition to University of Utah doctoral students Guang Tian, Torrey Lyons, and David Proffitt, Mercedes Beaudoin of the University of Utah assisted on the Englewood case study. The multimodal consulting firms of Fehr \& Peers and NelsonlNygaard were responsible for data collection and processing. They did an excellent job in what, due to the mix of land uses comprising transit-oriented development, is a logistical and analytical challenge.

For me, this two-year study represents a continuation of a 25-year effort to understand and quantify relationships between land use and transportation, or more precisely, the built environment and travel. Back in the early 1990s, when research on the built environment and travel began in earnest, there was a line of thinking that said that sociodemographics alone explained travel choices, basically that Americans who could afford a car would drive like mad regardless of density of development, land use diversity, urban design, destination accessibility, and distance to transit. After 25 years of high-quality studies, we know that the D variables listed above also affect people's travel choices. In dense, diverse, welldesigned, destination-accessible, and transit-proximate developments, people with the same demographics drive less and walk and use transit more than they do in suburban sprawl. The issue at this point is not whether causal relationships exist, but the magnitude of these relationships.

Which leads us to this study of trip and parking generation at transit-oriented developments, or TODs. TODs are the ultimate example of coordination between land use and transportation. The transportation in this case is high-quality transit and pedestrian facilities. The land use is dense, mixed-use, pedestrianoriented, and adjacent to transit. In this study, in particular, we explore the effect of a sixth D variable, travel demand management via parking management. While the other D variables have their effects on all three outcome variables studied herein (mode shares, vehicle trip generation, and peak parking generation), so do parking supply and price.

For the first time, for a sample of five exemplary TODs, we provide hard numbers on the mode shares, vehicle trip reductions, and parking reductions that can be achieved with transit-oriented development. We acknowledge in the executive summary and concluding chapter, that five is a small sample, and that much remains to be learned about the transportation benefits of TODs. We ourselves will soon conduct trip and parking generation studies at two additional TODs that are larger than the five studied in this report, and thus would be expected to capture more of the total trips internally, nearly all of which will be walk trips. We call on other researchers to join us in this effort.

Reid Ewing

Department of City and Metropolitan Planning

University of Utah 


\section{Table of Contents}

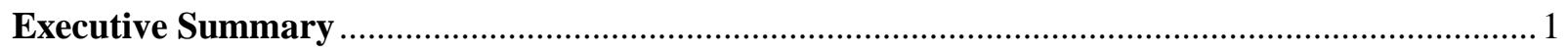

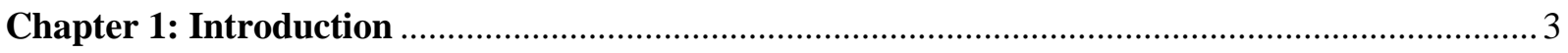

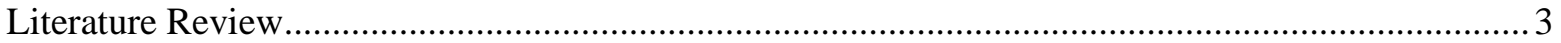

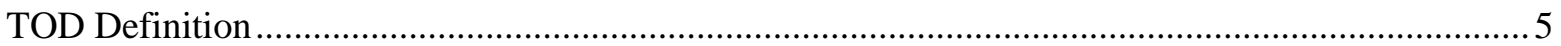

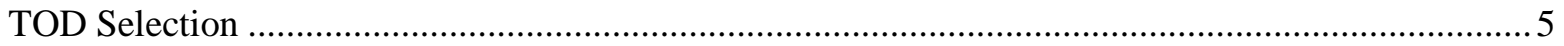

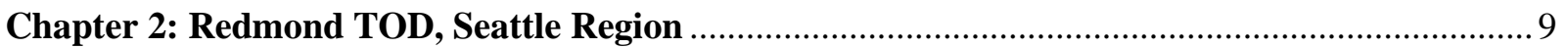

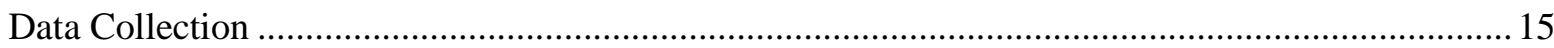

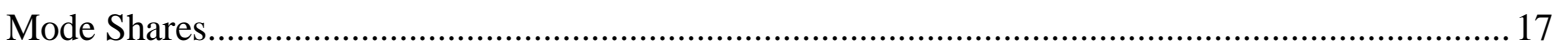

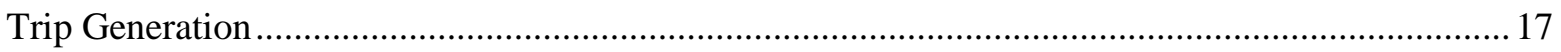

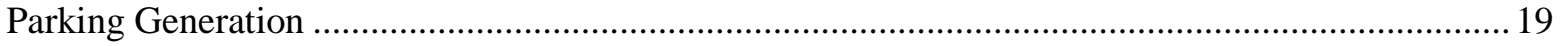

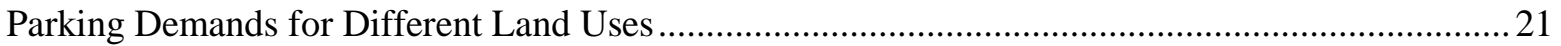

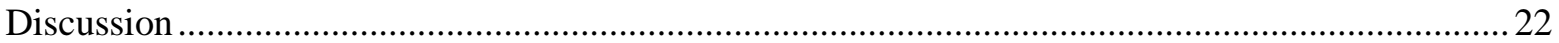

Chapter 3: Rhode Island Row TOD, Washington, D.C. Region...................................................2

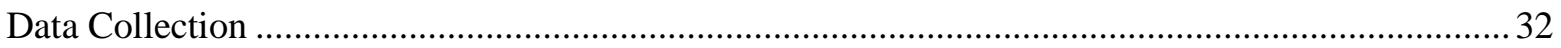

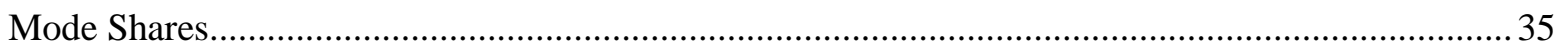

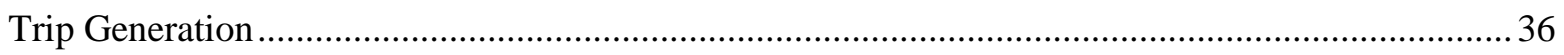

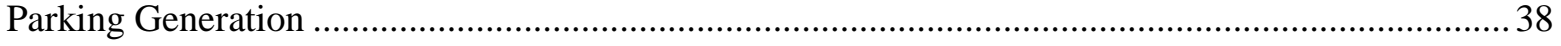

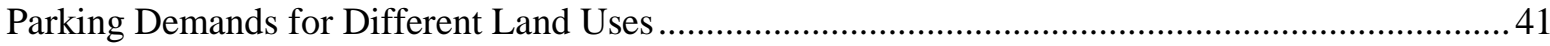

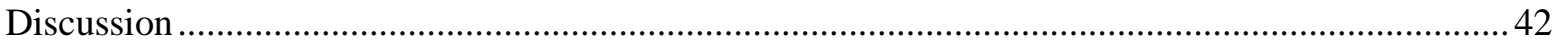

Chapter 4: Fruitvale Village TOD, San Francisco Region...................................................... 44

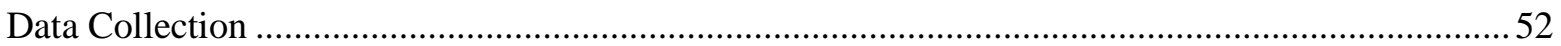

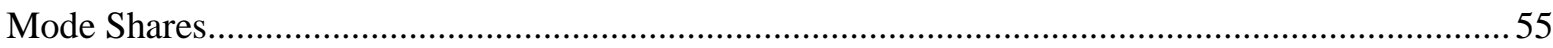

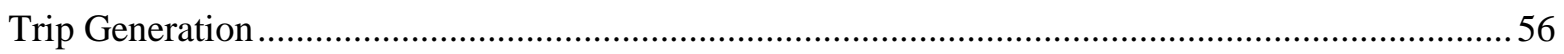

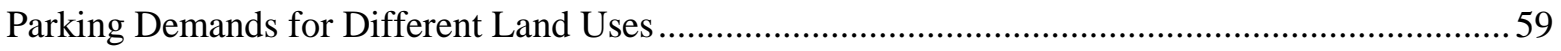

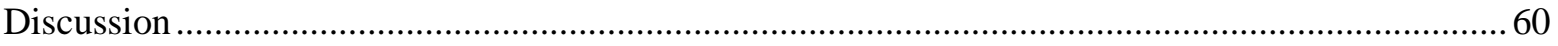

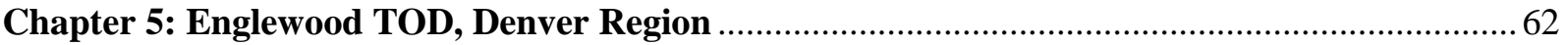

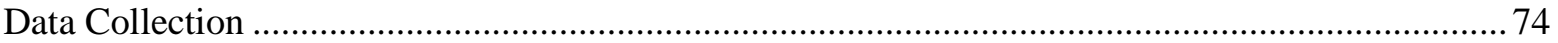

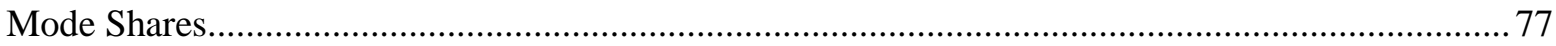

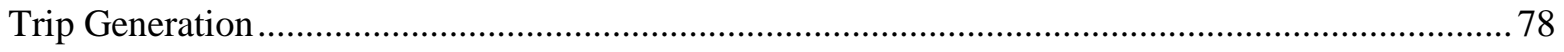

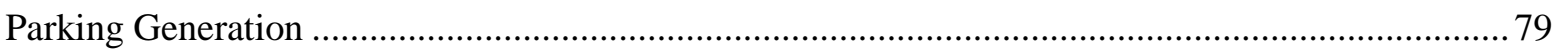

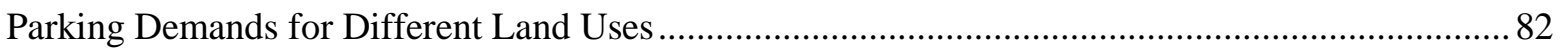

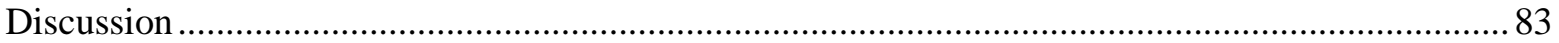




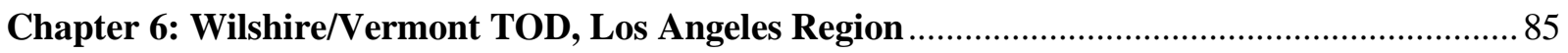

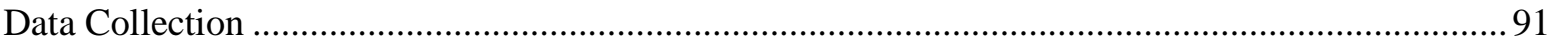

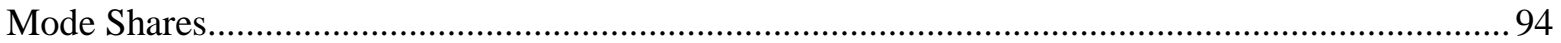

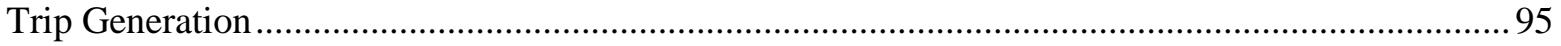

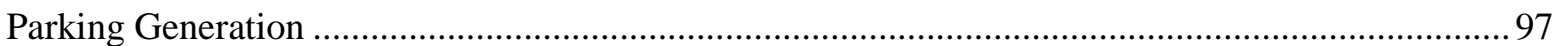

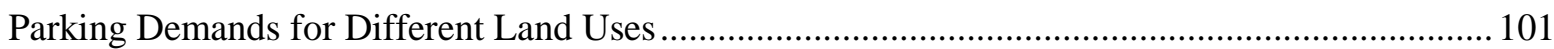

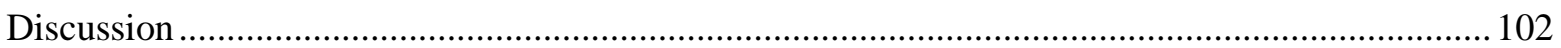

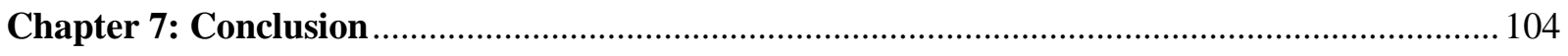

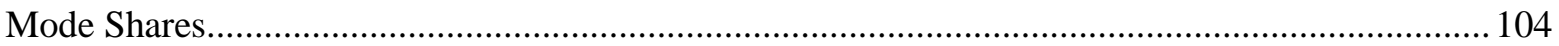

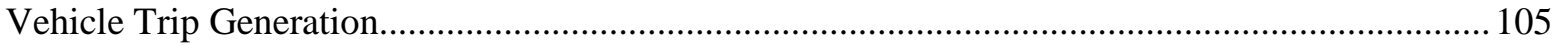

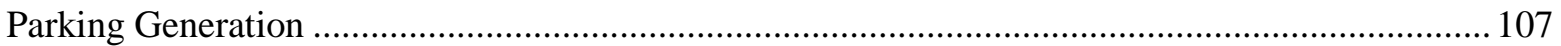

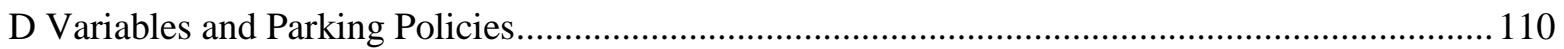

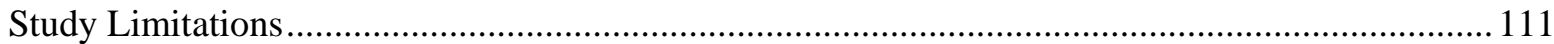

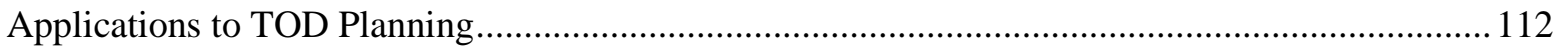

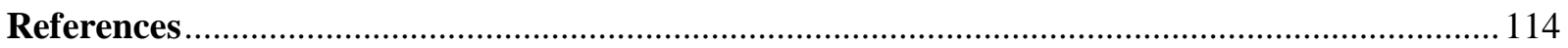




\section{Executive Summary}

The decision of how best to allocate land around transit stations is a debated topic, with transit officials often opting for park-and-ride lots over active uses such as multifamily housing, office, and retail organized into transit-oriented developments (TODs). Providing large park-and-ride lots has been the default strategy to maximize transit ridership in the short run. But is it the best strategy in the long run? The debate continues when land is developed, with officials usually assuming that TODs require the same number of parking spaces as conventional development and that transit stations require the same number of park-and-ride spaces as non-TOD stations, even if much of the travel demand is non-auto and much of the transit demand is generated by TODs themselves.

In practice, guidelines for providing parking and mitigating vehicle trips come mainly from the Institute of Transportation Engineers (ITE) Trip Generation Manual and the ITE Parking Generation manual. However, both manuals have well-known shortcomings. Most importantly they focus exclusively on suburban locations with limited transit and pedestrian access, limiting the manuals' recommendations to auto-dependent locations. Of course, TODs are designed to be the opposite of auto-dependent. Therefore, the goal of this study is to determine how many fewer vehicle trips are generated at TODs, and how much less parking is required at TODs, than ITE guidelines would suggest.

To answer these questions, we measure trip and parking generation at five TODs using a methodology that is the most robust published to date. As far as we can determine, this is the first study to estimate peak parking generation rates for mixed-use TODs. Also, this is only the second study to estimate vehicle trip generation rates for such developments. And it is one of the first to estimate mode shares for such developments.

The sample of TODs in this study consists of Redmond TOD in the Seattle region, Rhode Island Row in the Washington, D.C. region, Fruitvale Village in the San Francisco/Oakland region, Englewood TOD in the Denver region, and Wilshire/Vermont in the Los Angeles region. The study is limited to five TODs due to the labor intensiveness and cost of data collection.

These TODs meet several criteria. For our purposes, TODs are developed by a single developer under a master development plan, and can also include a clustering of development projects near transit facilities that are developed by one or more developers pursuant to a master development plan. TODs are relatively dense, mixed-use, pedestrian-friendly developments adjacent to high-quality transit with self-contained parking (so we can count associated parking spaces and parked cars).

For travel research purposes, developments are often characterized in terms of D variables. The five TODs studied in this project are more or less exemplary of the Ds. All contain a diverse land use mix, though Fruitvale Village could use more residential development and Redmond, in particular, could use more commercial development. All have public spaces, ample sidewalks, street trees, curbside parking, small building setbacks, and other features that make them well designed from a pedestrian standpoint. All minimize distance to transit, literally abutting transit stations. Fruitvale Village and Rhode Island Row are served by two of the best rail systems in the nation, giving them exemplary destination accessibility via transit. Wilshire/Vermont has exemplary bus accessibility as well. Several provide affordable housing, and thus attract the demographics most likely to use transit and walk. Two have high residential densities, and one has a high intensity of commercial development. And two or perhaps three 
have parking management policies that can be considered progressive, these falling under the heading of demand management.

In partnership with consulting firms Fehr \& Peers and NelsonlNygaard, we conducted parking supply and occupancy studies and building access counts as well as intercept surveys at the five TODs. We used these data to analyze travel mode splits, vehicle trip generation, and peak parking demand, which allows us make recommendations for land use and parking policies at new TOD developments.

Simply put, TODs create significantly less demand for parking and driving than conventional suburban developments. With one exception, peak parking demand is less than one half the parking supply guideline in the ITE Parking Generation manual. Also, with one exception, vehicle trip generation rates are about half or less of what is predicted in ITE Trip Generation Manual. Automobile mode shares vary widely, but are as low as a quarter of all trips, the balance being mostly transit and walking trips. Guidelines are provided for the use of the statistics from this study in the final chapter.

The only way to increase the external validity (generalizability) of this study is to expand the sample of TODs studied, particularly including larger TODs with higher internal capture rates. In this vein, we call for additional research on trip and parking generation at TODs. TODs, as we have defined them, are an increasingly common development type. In our home region of Salt Lake City alone, there are plans for nine TODs similar to those studied, including adjacency to rail stations. Creating a respectable sample of TODs with trip and parking data is too big a task to take on alone. 


\section{Chapter 1: Introduction}

The decision on how best to allocate land around transit stations is a debated topic, with transit officials often opting for park-and-ride lots over active uses such as multifamily housing, office, and retail organized into transit-oriented developments (TODs). Providing large park-and-ride lots has been the default strategy to maximize transit ridership in the short run. But is it the best strategy in the long run? The debate continues when land is developed, with officials usually assuming that TODs require the same number of parking spaces as conventional development and that transit stations require the same number of park-and-ride spaces as non-TOD stations, even if much of the travel demand is non-auto and much of the transit demand is generated by TODs themselves.

Balancing the amount of parking at TODs with the need to create a pedestrian-friendly environment and to encourage mixed-use development can be complicated. There are only a few studies of vehicle trip generation (Arrington and Cervero, 2008; Cervero and Arrington, 2008; Zamir et al. 2014) and parking demand (Cervero, Adkins, and Sullivan, 2010; Rowe et al. 2011; Serafin et al. 2010) at multifamily developments near transit. To our knowledge, there is only one study of vehicle trip generation at TODs (defined as mixed-use developments - Handy et al. 2013) and no study of parking demand at TODs (again, defined as mixed-use developments). The question of how much vehicle trip and parking demand reduction occurs with TOD is largely unexplored in the literature. Everyone agrees that there should be some reduction, but is it 20 percent? Thirty percent? Forty percent? Or some other number? This study gives an answer, albeit for only five TODs. And the reduction is huge. We hope these findings will spur additional research.

In this study, we define TODs with seven criteria and identify 10 TODs that meet all criteria in 10 metropolitan regions: Atlanta, Boston, Denver, Los Angeles, Portland, Salt Lake City, San Diego, San Francisco, Seattle, and Washington D.C. We measure trip and parking generation at TODs in five of these regions, using a methodology that is the most robust published to date. We want, in particular, to determine how many fewer vehicle trips are generated at TODs than the Institute of Transportation Engineers (ITE) Trip Generation Manual suggests, and how much less parking is required at TODs than the ITE Parking Generation manual suggests.

Consulting partners, Fehr \& Peers and Nelson\Nygaard, conducted parking supply and occupancy studies and building access counts as well as intercept surveys at the five TODs. We use these data to analyze travel mode splits, vehicle trip generation, and peak parking demand, which allows us make recommendations for land use and parking policies at new TOD developments.

\section{Literature Review}

First we review the literature on trip generation at TODs. The ITE Trip Generation Manual itself states that its "[d]ata were primarily collected at suburban locations having little or no transit service, nearby pedestrian amenities, or travel demand management (TDM) programs" (ITE 2004, pp. 1). It goes on to say: "At specific sites, the user may wish to modify trip-generation rates presented in this document to reflect the presence of public transportation service, ridesharing, or other TDM measures; enhanced pedestrian and bicycle trip-making opportunities; or other special characteristics of the site or surrounding area" (ITE 2004, pp. 1). This kind of modification is seldom done in practice. 
Surveying 17 housing projects near transit in five U.S. metropolitan areas, Cervero and Arrington (2008) found that vehicle trips per dwelling unit were substantially below the ITE's estimates. Over a typical weekday period, the surveyed housing projects averaged 44 percent fewer vehicle trips than that estimated by using the ITE manual (3.754 versus 6.715). Another study by the San Francisco Bay Area Metropolitan Transportation Commission found that residents living near transit generated half as many vehicle miles traveled (VMT) as their suburban and rural counterparts (SFBAMTC 2006). At the same time, Bay Area residents living in developments near transit are reported to have higher rates of transit trips than living at greater distances (Faghri and Venigalla 2013; SFBAMTC 2006; Zamir et al. 2014), especially for commuting trips (Arrington and Cervero 2008; Cervero 1994; Faghri and Venigalla 2013; Lund et al. 2004; Lund et al. 2006).

Next we review the literature on parking generation at transit-served sites. The ITE Parking Generation manual notes that study sites upon which the manual is based are "primarily isolated, suburban sites" (ITE 2010). Studies show that the vehicle ownership is lower in transit-served areas than those that are not transit-served (Faghri and Venigalla 2013; Zamir et al. 2014). By comparing parking-generation rates for housing projects near rail stops with parking supplies and with ITE's parking-generation rates, Cervero et al. (2010) found there is an oversupply of parking near transit, sometimes by as much as 25-30 percent. Oversupply of parking spaces may result in an increase in vehicle ownership (Cervero and Arrington 2008). This is supported by the strong positive correlation between parking supply and vehicle ownership (Chatman 2013; Guo 2013) and auto use (Chatman 2013; Weinberger 2012; Weinberger et al. 2009).

A barrier to creating TODs in many areas is "parking replacement policies" that require the developer to replace park-and-ride spaces on a one-to-one basis at a cost of $\$ 10,000$ to $\$ 15,000$ per parking space (Arrington and Cervero 2008). These policies increase the cost of TOD development substantially, especially because some estimates peg the price of a single parking stall even higher, at $\$ 20,000$ to $\$ 40,000$, or as much as $\$ 60,000$ in high-value real estate markets (i.e., San Francisco) (Reconnecting America 2009). According to Cervero and Landis (1997), "An oversupply of park-and-ride lots at transit stations ... can undermine regional land-use benefits." Developers and policy makers should agree upon parking supply and pricing policies that support the overall objectives of TODs (Willson 2005).

Our review of the TRID database found few resources on parking at TODs. One team of researchers sought to "understand the tension between access (parking and otherwise) and transit-oriented development (TOD) and learn how practitioners successfully resolved these tensions" (Edgar et al. 2013). The team performed a scan to learn of parking policies and TOD practices in five regions: San Francisco/Oakland, Denver, Los Angeles/South Pasadena, San Diego, and Boston. They found that parking could be a source of tension in areas where land value is at a premium, density is high, and where transit riders are accustomed to large park-and-ride lots. Too much parking may interfere with the human design of a TOD and compromise what should be a pedestrian-friendly environment.

The parking policy recommended by Martin and Hurrell (2012) is one of "constrained" parking that is not included in leases or other TOD operational costs. This will result in the greatest line-haul ridership for the TOD. In addition, they recommend that transit riders pay for parking once parking capacity is reached in order to cover maintenance costs for the parking lot or garage. The idea here is that when riders have to pay for parking, they demand less of it. 
Because data are difficult and expensive to collect, much of the research on parking at TODs presents more general findings. Our study quantifies trip and parking generation at TODs in five diverse metropolitan regions: Denver, Los Angeles, San Francisco, Seattle, and Washington, D.C.

\section{TOD Definition}

TODs are widely defined as compact, mixed-use developments with high-quality walking environments near transit facilities (ITE 2004, pp. 5-7). For this study, we limited our sample of TODs to sites developed by a single developer under a master development plan. TODs may also include a clustering of development projects near transit facilities developed by one or more developers pursuant to a master development plan.

The first three criteria used to select TODs for this study are consistent with the definition above. TODs must be:

(1) Relatively dense (with multi-story development),

(2) Mixed use (with residential, retail, entertainment, and sometime office uses in the same development), and

(3) Pedestrian-friendly (with streets built for pedestrians as well as autos and transit).

We have added four additional criteria to maximize the utility of the sample and data. TODs must be:

(4) Adjacent to transit (literally abutting and hence integrally related to transit),

(5) Built after a high-quality transit line was constructed or proposed (and hence with a parking supply that reflects the availability of high quality transit),

(6) Fully developed or nearly so, and

(7) With self-contained parking.

By self-contained parking, we mean having dedicated parking, in one or more parking garages or lots, for the buildings that comprise the TOD. This criterion is dictated by our need to measure parking demand for the combination of different land uses that comprise the TOD. The criterion precludes TODs in a typical downtown that share public parking with non-TOD uses. This obviously constitutes a limitation on our study's external validity, but one that is self-imposed. In a typical downtown with public parking, it is impossible to tell which parked cars are associated with which land uses. Thus, our findings will be most applicable to the many proposed and self-contained TODs in less urban or more suburban locations.

\section{TOD Selection}

Given our seven criteria, we selected good (arguably the best) self-contained TODs in each of 10 regions. For each region, we tried to identify TOD candidates from multiple sources in a multi-step process. The first step was to consider mixed use developments (MXDs) near transit from an MXD database collected for another purpose (Tian et al. 2015). The MXD database includes developments in six of the 10 study regions: Atlanta, Boston, Denver, Portland, Salt Lake City, and Seattle. We identified all MXDs in close proximity to transit stations in the six regions. 
The second step was to ask our teaming partners' branch offices to identify candidate sites within their regions that met our seven criteria. Concurrently, we contacted regional transit operators and/or metropolitan planning organizations in the 10 regions with the same question. A surprising number of transit agencies and MPOs have staff specifically dedicated to promoting TODs. These were contacted, told our criteria, and asked for the best local examples of TOD.

The third step was to review candidate sites with Google Earth imagery to check for clustering of buildings around transit stations, typically with well-defined boundaries. This was followed by the use of Google Street View to establish that TOD criteria (dense, mixed use, pedestrian-friendly with selfcontained parking) were actually met. Several top candidate TODs were ranked in this manner for each metropolitan area.

The final step was to visit each of the metropolitan areas and, once there, take transit from one candidate station area to the next. In each location, we walked around and through the development to determine whether our criteria were in fact met and went to the property management office to get contact information. We also made a photographic record of each development. In virtually all cases, the relative ranking of sites changed with on-the-ground inspections.

Ultimately, we identified 10 TODs-one in each region-that met our criteria and were feasible to study. Here the process of TOD selection got messy. One practical consideration was our decision to obtain approval from property managers to conduct these studies, particularly because we would be going into their parking garages at all hours to conduct parking occupancy counts. We were not able to obtain permission from Station Landing in Boston, City College Trolley Station in San Diego, or Del Mar in Los Angeles. That led to substitutions (e.g., Wilshire/Vermont for Del Mar and Ashmont for Station Landing).

Another practical consideration was budgetary. Some of the selected TODs are so large and have so many building entrances that the consultants would have exceeded their subconsultant budgets if these had been included in our sample. This was the case with Lindbergh City Station in Atlanta, Orenco Station in Portland, and City Creek Center in Salt Lake City. It was estimated, for example, that one day of data collection and subsequent data processing at City Creek Center would cost $\$ 24,000$. This also led to TODs being dropped from our sample. Budgetary constraints ultimately limited our study to five TODs out of the 10 possible sites.

The decision to limit our sample to smaller TODs suggests that our case studies may underestimate the potential trip and parking reductions associated with TOD. This is the case because smaller developments have limited potential for internal capture of trips, which is to say, limited numbers of trips that both begin and end within the TOD. While it is certainly possible that residents of Redmond TOD (Seattle see below) will dine in the Indian restaurant that is part of the development, with so few trip attractions within the development, it seems more likely that they will dine, when they dine out, elsewhere within downtown Redmond. Orenco Station, in contrast, offers a much more complete set of attractions. Our published work elsewhere shows that larger developments have higher rates of internal capture (Tian et al., 2015).

Table 1.1 provides descriptive statistics on mode shares for work trips, median household income and vehicle ownership for the Census block groups containing the exemplary TODs in all 10 regions. 
Generally, these Census block groups have fairly high walk or transit mode shares on the journey to work. However, all-purpose walk shares for the TODs themselves are always much higher than commute walk shares are for their Census blocks (see Table 7.1). The fact that TOD walk shares are always much higher probably is due the fact that walking is disproportionately used for non-work trips. And all-purpose transit shares are generally higher than commute transit shares for their Census blocks (see Table 7.1). The fact that TOD transit shares are not higher in all cases probably is due to the fact that transit is disproportionately used on work trips.

Table 1.1. Journey to Work Mode Shares and Vehicle Ownership for the Census Block Groups That Contain Exemplary TOD Sites

\begin{tabular}{|c|c|c|c|c|c|c|c|}
\hline \multirow[t]{2}{*}{ TOD } & \multirow{2}{*}{$\begin{array}{c}\text { Metropolitan } \\
\text { Area }\end{array}$} & \multirow{2}{*}{$\begin{array}{c}\text { TOD } \\
\text { Area } \\
\text { (gross } \\
\text { acres)* }\end{array}$} & \multirow{2}{*}{$\begin{array}{c}\text { GISJOIN (Census } \\
\text { block group ID) }\end{array}$} & \multicolumn{2}{|c|}{ Journey to work } & \multirow{2}{*}{$\begin{array}{c}\text { Median } \\
\text { HH } \\
\text { income }\end{array}$} & \multirow{2}{*}{$\begin{array}{l}\text { Vehicle } \\
\text { per HH }\end{array}$} \\
\hline & & & & $\begin{array}{l}\text { Walk } \\
\text { share (\%) }\end{array}$ & \begin{tabular}{|l|} 
Transit \\
share $(\%)$
\end{tabular} & & \\
\hline $\begin{array}{l}\text { Lindbergh City } \\
\text { Center }\end{array}$ & Atlanta & 38 & G13012100094021 & 2.43 & 14.03 & 55,500 & 0.83 \\
\hline Station Landing & Boston & 13 & G25001703398011 & 0 & 23.99 & 95,391 & 1.00 \\
\hline Englewood & Denver & 30 & G08000500057002 & 2.55 & 18.10 & 46,976 & 0.88 \\
\hline Wilshire/Vermont & Los Angeles & 3.2 & G06003702111202 & 10.33 & 7.41 & 45,556 & 0.97 \\
\hline Orenco Station & Portland & 50 & G41006700326071 & 5.68 & 6.98 & 74,844 & 0.91 \\
\hline City Creek Center & Salt Lake City & 20 & G49003501140001 & 13.51 & 8.42 & 39,375 & 0.75 \\
\hline Redmond TOD & Seattle & 2.5 & G53003300323092 & 3.00 & 13.28 & 96,701 & 0.89 \\
\hline $\begin{array}{l}\text { City College } \\
\text { Trolley Station }\end{array}$ & San Diego & 2 & G06007300052002 & 16.08 & 9.71 & 21,962 & 0.72 \\
\hline Fruitvale Village & San Francisco & 3.4 & G06000104061001 & 13.90 & 23.22 & 56,667 & 0.85 \\
\hline Rhode Island Row & $\begin{array}{l}\text { Washington, } \\
\text { D.C. }\end{array}$ & 6 & G11000100091022 & 1.86 & 31.00 & 41,969 & 0.88 \\
\hline National average & - & - & - & 2.81 & 5.00 & 57,650 & 0.88 \\
\hline
\end{tabular}

*This only includes the development itself and does not include parking areas for transit users, surrounding streets, etc.

Table 1.2 provides statistics on the intensity of development for the five TODs studied in the report. FARs for commercial development (which are calculated as commercial floor area divided by acreage of commercial and mixed uses) are relatively low, while gross residential densities exceed the guidelines in most transit-oriented design manuals (Ewing and Bartholomew 2013). The typical TOD has ground floor retail and apartments above, meaning that the commercial FAR is generally limited to 1.0, while the residential density depends on the number of stories. Fruitvale Village TOD, with its heavy concentration of clinics, high school, library, etc., is one exception to the low FAR rule. But the very substantial vehicle-trip and parking reductions documented in this study suggest that very high density/intensity of development is not a sine qua non for success.

Table 1.2. Net and Gross Residential Densities, and Floor Area Ratios for Commercial Uses, for the Five TODs Studied in this Report 


\begin{tabular}{|l|l|r|r|r|r|r|}
\hline \multicolumn{1}{|c|}{ TOD } & \multicolumn{1}{|c|}{$\begin{array}{c}\text { Metropolitan } \\
\text { Area }\end{array}$} & $\begin{array}{c}\text { Gross Area } \\
\text { (acres) }\end{array}$ & $\begin{array}{c}\text { Gross } \\
\text { Residential } \\
\text { Density } \\
\text { (units per } \\
\text { gross acre) }\end{array}$ & $\begin{array}{c}\text { Net } \\
\text { Residential } \\
\text { Area (acres) }\end{array}$ & $\begin{array}{c}\text { Net } \\
\text { Residential } \\
\text { Density (units } \\
\text { per net acre) }\end{array}$ & $\begin{array}{c}\text { Gross } \\
\text { Commercial } \\
\text { FAR (for } \\
\text { retail and } \\
\text { office uses) }\end{array}$ \\
\hline Redmond TOD & Seattle & 2.5 & 129 & 2.5 & 129 & 0.11 \\
\hline Rhode Island Row & $\begin{array}{l}\text { Washington, } \\
\text { D.C. }\end{array}$ & 6 & 46 & 6 & 46 & 0.27 \\
\hline Fruitvale Village & San Francisco & 3.4 & 14 & 3.4 & 14 & 0.94 \\
\hline Englewood & Denver & 30 & 15 & 10.7 & 41 & 0.25 \\
\hline Wilshire/Vermont & Los Angeles & 3.2 & 140 & 3.2 & 140 & 0.27 \\
\hline
\end{tabular}




\section{Chapter 2: Redmond TOD, Seattle Region ${ }^{1}$}

The Redmond TOD is our choice in the Seattle region. It was our pilot study, and we used it to develop and test protocols for data collection and develop and implement analysis procedures. The only other TOD candidate considered in the Seattle region was North Station, and it presented problems of data collection.

The Redmond TOD is built on the site of a former park-and-ride lot and bus transfer facility. The private developer Trammell Crow Residential built the mixed-use Veloce building with ground-floor retail and apartments above. It was completed in 2009. It occupies the western portion of the former park-and-ride lot. The multi-story development was the first of several residential projects of similar size in downtown. The site itself is on the northern edge of downtown, two blocks from the commercial center.

The associated Transit Center and the Park-and-Ride Garage were developed jointly by the King County Department of Transportation, the City of Redmond, and Sound Transit. In Phase 1, completed in 2008, the \$7.2 million Transit Center was built on the site of the existing bus transfer facility. It replaced a smaller, cramped set of bus stops originally constructed in 1978.

In Phase 2, completed in 2009, King County Metro designed, constructed, and funded the park-and-ride garage. It occupies the eastern portion of the former park-and-ride lot. The parking garage, being on a site purchased with federal grant funds, was subject to a one-for-one parking replacement policy for park-andride users.

Other improvements included wider sidewalks, street lights, landscaping, more visible pedestrian crossings, better sight distances for buses using the turnaround, and fewer vehicle/bus/pedestrian conflicts due to removal of the middle park-and-ride driveway.

The westbound bus stops of the Transit Center and Redmond Skate Park are on the north side of NE 83rd Street, while the Veloce building, eastbound bus stops, and park-and-ride garage are on the south side. With NE $83^{\text {rd }}$ Street having low traffic volumes and a pedestrian-friendly design, the four components form a unified whole (see Figure 2.1).

${ }^{1}$ For this case study, we conducted interviews with Gary Lee from the City of Redmond and Gary Prince from the King County Department of Transportation. 


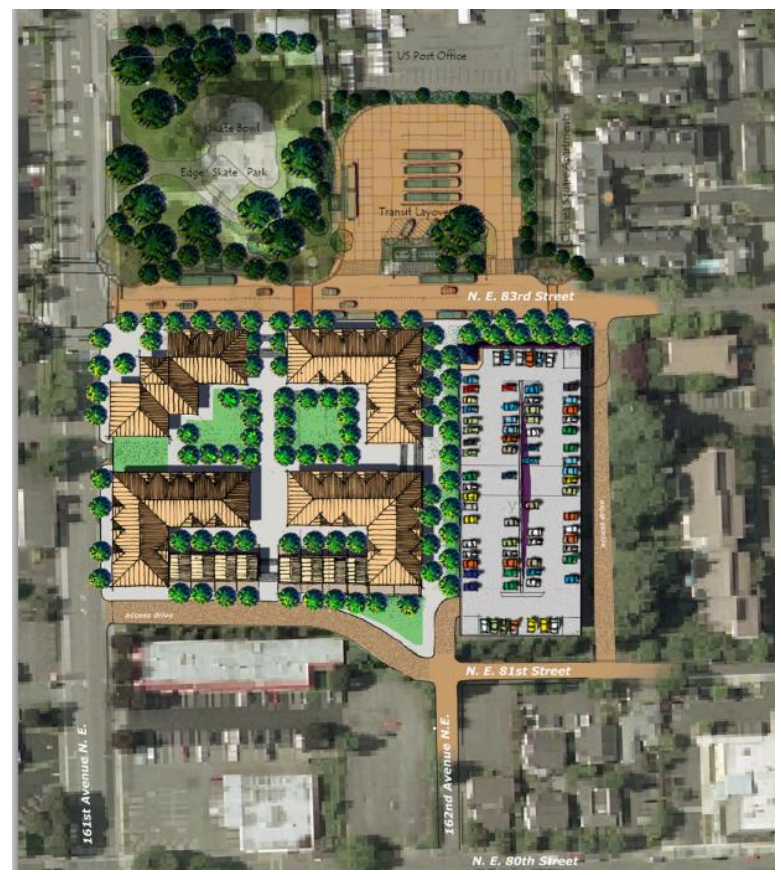

(a) Site Plan (source:

http://www.kingcounty.gov/transportation/kcdot/PlanningAndPolicy/RegionalTransportationPlanning/Tra nsitOrientedDevelopment/Projects/Redmond.aspx)

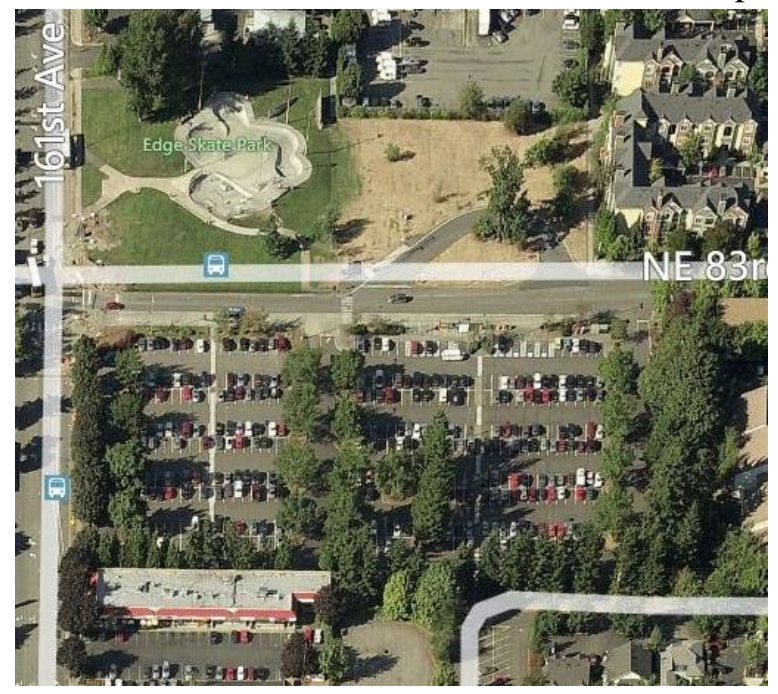

(b) Before the TOD Project

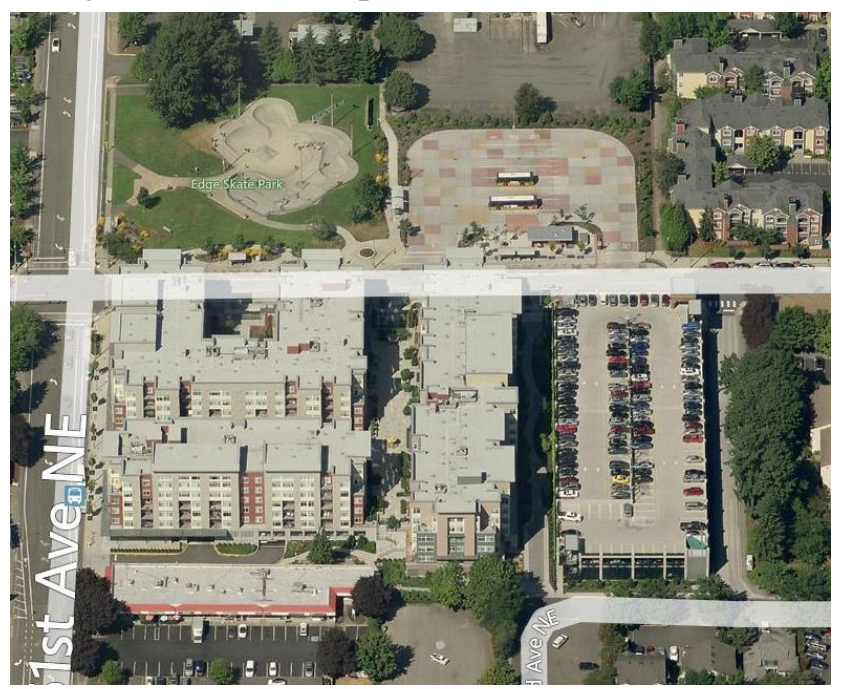

(c) After the TOD Project

Figure 2.1. Redmond Transit Center and TOD: (a) Site Plan; (b) Before the TOD Project; (c) After the TOD Project

\section{History}

The history of the Redmond TOD is instructive. In 1993, the City of Redmond amended its downtown zoning ordinance and comprehensive plan to encourage transit-oriented development (what at the time was referred to as neo-traditional development). The allowable density was raised from 36 to 72 dwelling units per acre in an effort to encourage structured parking. As with form-based codes, buildings were required to be placed at the back of sidewalk in order to create a better pedestrian realm. The required 
parking ratio was reduced from an average of two spaces per unit, depending on the number of bedrooms, to one space per unit regardless of the number of bedrooms, plus 0.25 spaces per unit for guests, for a total of 1.25 spaces per unit. Guest parking can be shared with retail uses.

In 2006, after a few new developments were completed at the higher density of $72 \mathrm{du} / \mathrm{ac}$, the city chose to remove the constraint on residential density to encourage a greater mix of unit sizes within the existing bulk/height limits. This decision came about because the $72 \mathrm{du} / \mathrm{ac}$ limit created mostly larger units, averaging 1,200 square feet or more. Allowable density was made unlimited, subject only to parking requirements and building height and setback restrictions. This meant developers could build as many units as they could provide parking for so long as they complied with building height and setback rules.

The development of the Veloce building followed these amendments almost immediately. The zoning amendment of 2006 did not change the parking requirements, which remained the same at about 1.25 spaces per unit, including guest parking. However, the city provided administrative design flexibility to its planning staff (with no public hearing for a variance), and in 2013 they approved residential development at 0.94 spaces per unit. The lower parking ratio requires a parking study by a licensed transportation engineer, and the Veloce building provides precedent for a mixed-use building that actually parks at a much lower ratio than approved in this case.

\section{Transit Connection}

Transit is a draw. The Redmond Downtown Transit Center has direct connections to Seattle and downtown Bellevue. It is served by Metro bus lines 221, 224, 232, 248, 930 DART, 931 DART, and RapidRide B Line; and Sound Transit Express 542 and 545 lines. Sound Transit doubles midday service on ST Express 545, adding extra peak period trips during times when loads are heaviest.

The Transit Center has six bus bays and a separate bus layover area that concentrates transit service into a downtown location. Improvements to the pre-existing bus transfer facility increased transit passenger loading capacity, expanded the bus loop north of NE 83rd Street to improve transit operations, and added bus layover capacity to the loop. Features include custom architectural transit passenger shelters and a streetscape design that complements the existing Redmond Skate Park.

The addition of off-street layover space and the transit turnaround significantly improves transit efficiency. These two elements allow King County Metro Transit to invest service hours in carrying passengers instead of "deadheading" empty buses to satellite layover locations. 


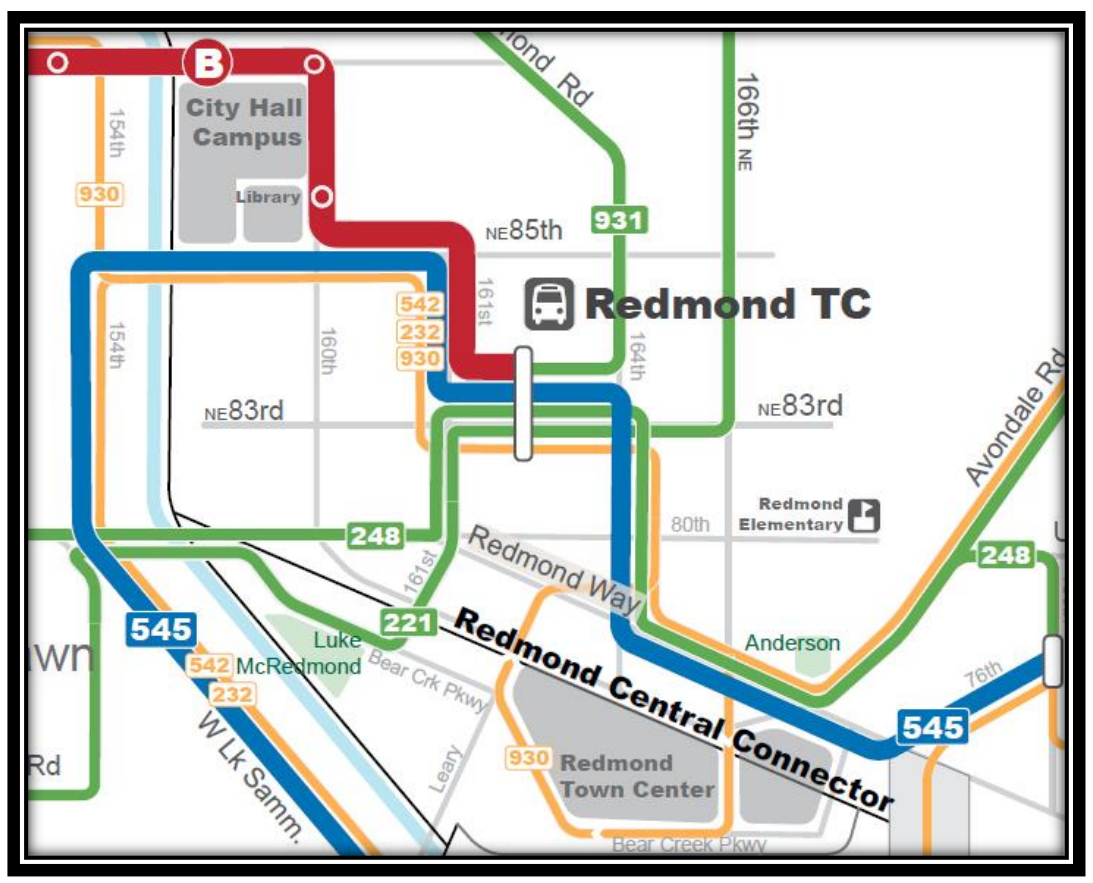

(a) Buses That Go Through Redmond Transit Center (source:

http://www.redmond.gov/common/pages/UserFile.aspx?fileId=160128)

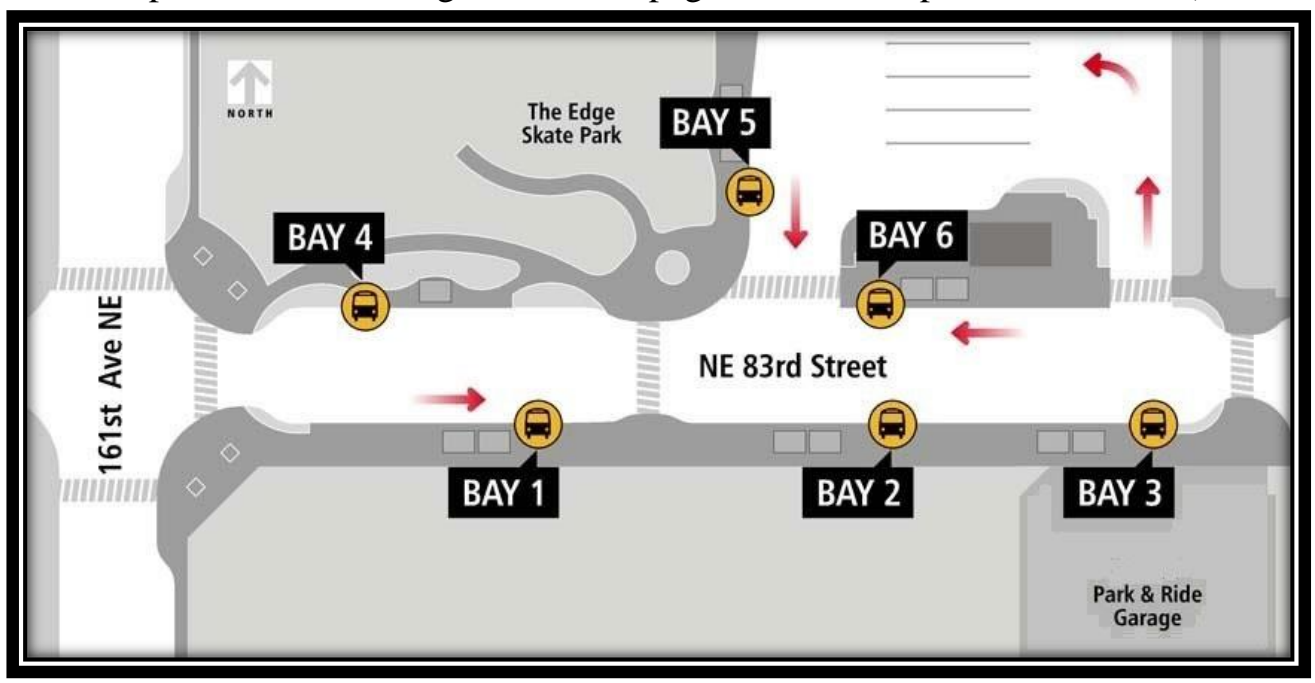

(b). Redmond Transit Center Boarding Locations (source:

http://metro.kingcounty.gov/tops/parknride/boarding/redmond-tc.html)

Figure 2.2. Transit Services at Redmond TOD

\section{The Development Itself}

The Veloce building is a 322-unit multifamily mixed-use project. Twenty percent of the units are affordable at 80 percent of the area's median income. The podium-style building has street level retail and two levels of parking below the three- to five-story apartment buildings. The project caters to young professionals who desire urban living, as well as to commuters. Light rail eventually will run next to the 
building, making it the hub of downtown Redmond. This project won the City of Redmond's 2012 Outstanding Design Award in recognition of its exceptional architectural contribution to the City.

Due to its location, the residential portion of the TOD was an instant success. It filled up quickly. The multifamily units were almost fully leased at the time this study was conducted in mid-2015 (see Table 2.2).

There is some evidence that the project has since catalyzed residential development downtown, as there are now several similar sized mixed-use buildings within a few blocks. The Veloce building provided an early example of dense housing with less parking than had been the norm. The retail portion, on the other hand, has not been as successful. It is not fully leased even as of 2016. At the time this study was conducted in mid-2015, a little over half of the retail space had been leased to a restaurant, an animal hospital, and a financial services office. The other half was vacant.

The fact that the residential component has outperformed the commercial component requires some explanation. The Veloce building is a couple of blocks from the downtown commercial core, not far for residential development but a disadvantage for commercial development. The road between the Transit Center and the TOD, NE $83^{\text {rd }}$ Street, is a low volume street with retail on only the south side of the street. The north side has the Skate Park and the Transit Center. The west side of the building is better situated for retail, being on a higher volume street, NE $161^{\text {st }}$ Avenue. But even NE $161^{\text {st }}$ Avenue is not ideally located relative to the downtown commercial core. The fact that ground floor retail has begun to lease up south of the TOD, in the core, suggests that the redevelopment boom that has affected downtown may eventually reach the Redmond TOD. Indeed, since our survey, the remaining commercial space on the west side of the building has been leased for a café.

The two-level parking garage/structure has 415 stalls located below the residential component of the project. The parking garage includes 379 stalls for building residents and 36 public parking stalls, with three signed for "new residents," three for "guests," four for "carpools," and 26 for "retail" customers and employees. The residential parking is leased at $\$ 90 /$ month for the reserved parking in the lower level, and $\$ 80 /$ month for access to non-reserved/resident shared parking in the upper level. Retail, guest, and carpool parking are separated from the residential parking (outside the gates) and available at no charge. Street parking with short-term parking capacity for up to eight vehicles in front (west frontage only) is free, but limited to two hours, from 9:00 am-5:00 pm, Monday to Friday, except holidays, as posted. In addition, a 40-foot, short-term loading zone is provided at the curb on the west frontage, immediately in front of the main pedestrian entrance to the building. Additional parking is provided for commuters; the Redmond Park-and-Ride Garage is a three-story structure with 383 free parking stalls and 12 bike lockers.

Table 2.2. Development Summary of Redmond TOD Project (5 acres)

\begin{tabular}{|l|l|l|l|}
\hline Land uses & Description & Unit & \multicolumn{1}{|l|}{ Occupancy* } \\
\hline Commercial & Ground floor & 11,740 square feet (sq. ft.) & $56.8 \%$ \\
\hline $\begin{array}{l}\text { Residential (called } \\
\text { Veloce building) }\end{array}$ & $\begin{array}{l}\text { 5 stories above } \\
\text { commercial }\end{array}$ & $\begin{array}{l}\text { 322 units (37 studio units, 173 } \\
\text { one bedroom units, and 112 } \\
\text { two bedroom units) }\end{array}$ & $96.9 \%$ \\
\hline Parking & Description & Unit & Occupancy** \\
\hline $\begin{array}{l}\text { Transit Parking-and- } \\
\text { Ride }\end{array}$ & $\begin{array}{l}\text { 3-level parking } \\
\text { structure }\end{array}$ & 383 stalls & $96.9 \%$ \\
\hline
\end{tabular}




\begin{tabular}{|l|l|l|l|}
\hline $\begin{array}{l}\text { Veloce development } \\
\text { parking }\end{array}$ & $\begin{array}{l}\text { 2-level underground } \\
\text { parking }\end{array}$ & $\begin{array}{l}415 \text { stalls (36 stalls for } \\
\text { residential visitors, retail } \\
\text { customers, and employees; } \\
379 \text { stalls for residents) }\end{array}$ & $69.6 \%$ \\
\hline
\end{tabular}

Note: * by May 28, 2015; **: the peak occupancy at May 28, 2015.

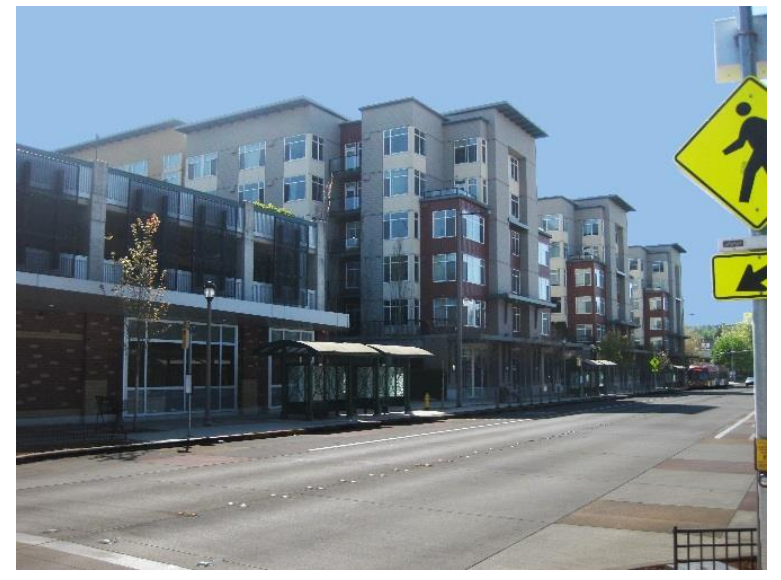

(a) Apartment Building and Park-and-Ride Garage

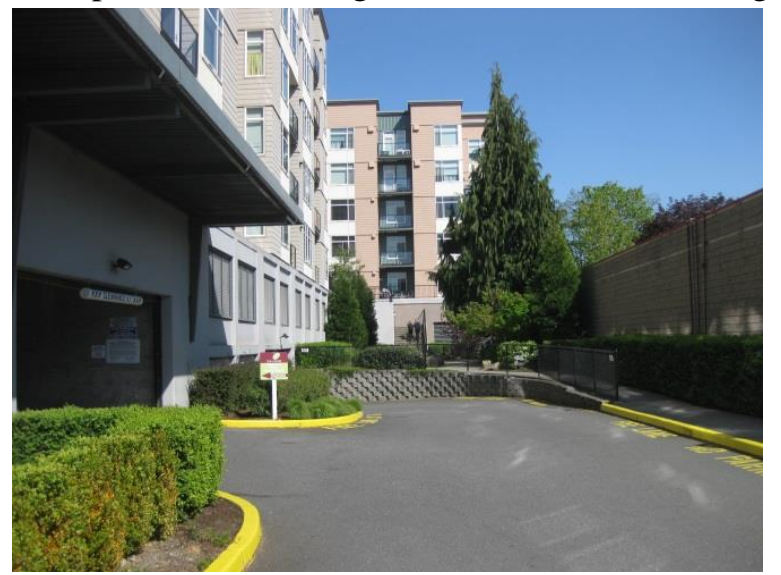

(c) Apartment Building with Underground Parking

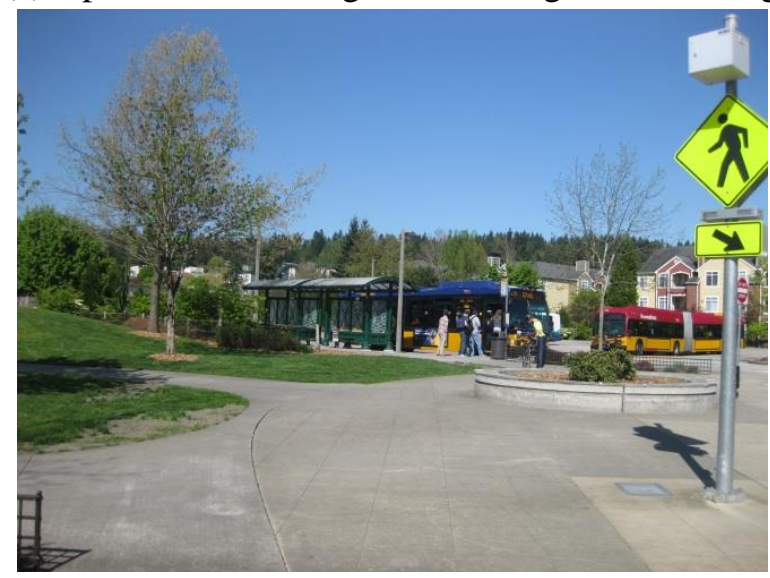

(e) Redmond Transit Center

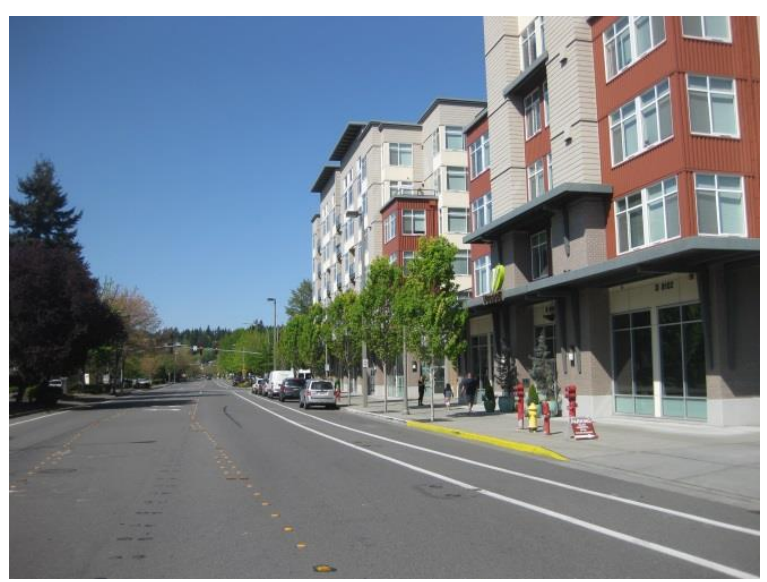

(b) Apartment Building with Ground Floor Retail

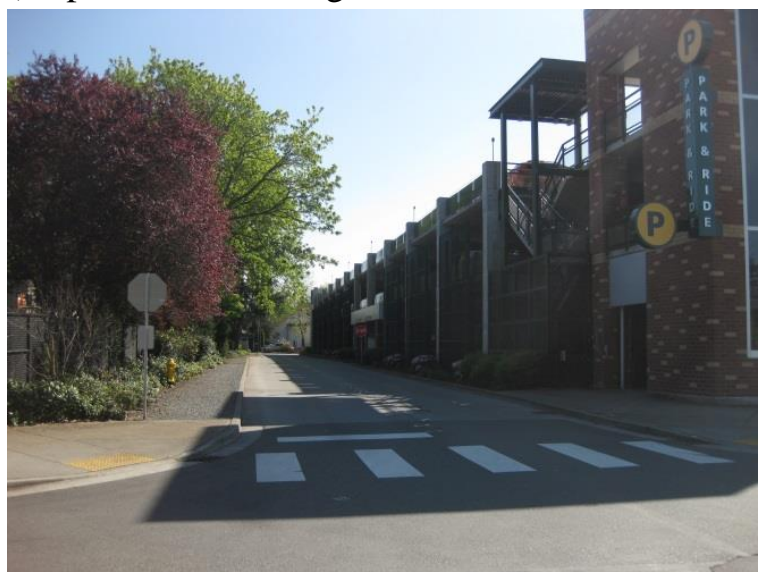

(d) Park-and-Ride Garage

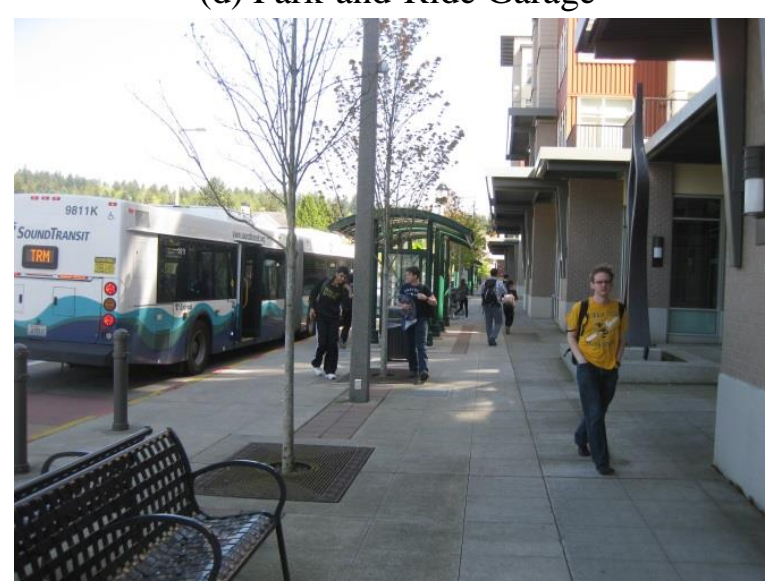

(f) Transit Users 


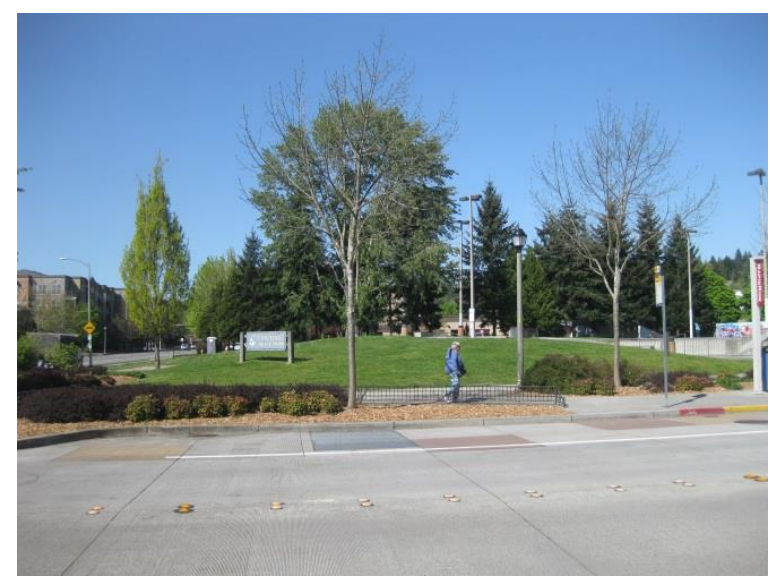

(g) Redmond Edge Skate Park

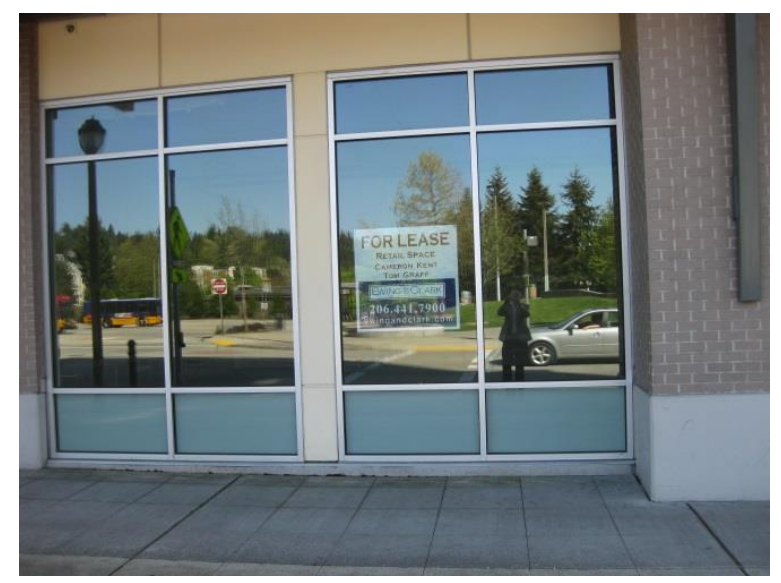

(h) Unleased Space

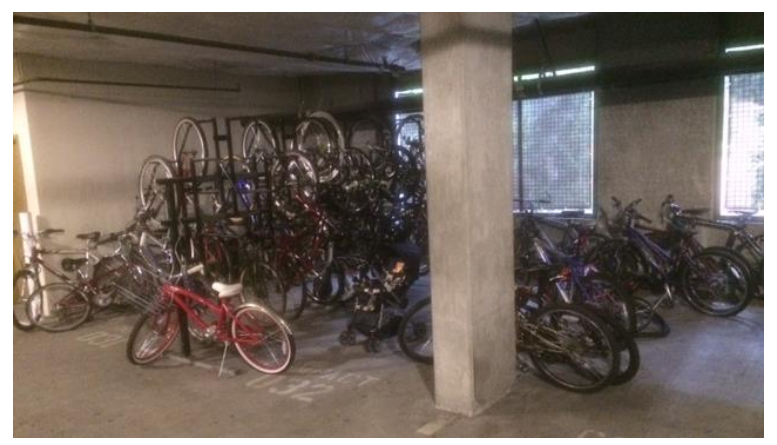

(i) Spillover bike parking at the apartment garage

Figure 2.3. Redmond TOD

\section{Data Collection}

The multimodal transportation planning firm NelsonlNygaard developed a data collection plan and protocols. The firm also managed data collection in the field and subsequent data entry for three types of travel data: (1) a full count of all persons entering and exiting the Veloce Building, (2) a brief intercept survey of a sample of individuals entering and exiting the building, and (3) parking inventory and occupancy surveys of all off-street parking accessory to the commercial and residential uses of the Veloce building and the co-located but separately managed off-street parking facility owned and operated by King County Metro Transit for day use by transit riders.

The intent of this approach was to develop an accurate measure of total trip generation associated with the commercial and residential uses at the site, as well as complementary travel survey and parking utilization data that provide a picture of the mode of travel, origin/destination, parking location - if applicable - and purpose for all trips to and from the building throughout the course of the day.

All survey and trip count data were recorded on location in Redmond TOD between 7:30 a.m. and 9:00 p.m. on Tuesday, May 28, 2015. Parking utilization was surveyed at each facility approximately every two hours during this period. An "overnight" count of parking occupancy was conducted at both the Veloce Building garage and the Redmond Transit Center Park-and-Ride lot from 1:00-2:00 a.m. on 
Tuesday, June 2, 2015, to determine parking occupancy during the anticipated period of peak utilization associated with the predominant residential use.

Separate teams of surveyors were employed to (a) count people entering/exiting at each building entrance, and (b) conduct intercept surveys (most intercept surveys were completed by undergraduate and graduate students at the University of Washington Colleges of Environmental Design or Engineering). All parking inventory and occupancy counts were conducted by NelsonlNygaard planning staff, who also supervised survey workers at building entrances.

Throughout the survey period, four people were employed to conduct trip counts. These surveyors were stationed on the public sidewalk in fixed positions where they could easily and continually observe primary entrances to the building. Counters on the north and west sides, and on the northeast corner of the building, tallied the number of people entering and exiting each door by hour. The counter on the southwest corner recorded pedestrians entering/exiting the lone south door, in addition to people entering/exiting the Veloce parking facility by bicycle or motor vehicle - noting vehicle occupancy when visible.

A separate team of surveyors - four all day, with a fifth added during peak periods of 7:30-9:30 a.m. and 4:30-7:30 p.m. - were employed to intercept and survey people entering and exiting the building ${ }^{2}$. These surveyors were stationed to the north, west, northeast and southwest of the building, covering all primary pedestrian entrances to the Veloce building, but were instructed to leave their stations as necessary to intercept and attempt to survey individuals seen moving toward an entrance or away from a building exit.

As a first step, surveyors noted whether the subject was observed "coming" or "going" to/from the building and the type and location of entrance/exit used, and recorded the time of intercept by checking a box on the data collection form associated with one of four 15-minute periods per hour.

People leaving the building were asked: (1) "How do you plan to get to your next destination?" (e.g., by what mode of travel?), and (2) What is the purpose of your trip? (e.g., "Going home," "Going to work," "Shopping," or "other").

People arriving at the building were asked: (1) "How did you get here?" (e.g., by what mode of travel?), and (2) What is the purpose of your trip? (e.g., "I live here/coming home," "coming to work," "shopping," or "other").

Individuals who indicated that they had arrived by or would be leaving by automobile were also asked where they parked their vehicle (e.g., "on-street," "in the [Veloce Building] garage" or at an "other" location/facility).

Surveyors counted and attempted to intercept only individuals observed walking to or from an entrance to the Veloce building (or, in observation of the garage entrance, only drivers and passengers in vehicles

\footnotetext{
${ }^{2}$ Note that for up to four hours - 7:30-9:30 am and 6:00-8:00 pm - a single surveyor positioned at the southwest corner of the building was tasked with both counting and intercept surveying of people entering and exiting the Veloce Building. This surveyor was responsible for observing people entering/exiting the little used South entrance, as well as counting and surveying people on the driveway to/from the parking garage.
} 
entering/exiting the garage driveway to/from the public street). Individuals waiting for the bus or walking between the bus stops and other trip origins/destinations, including the Redmond Transit Center park-andride garage, were not counted or surveyed. The intercept survey received 428 respondents.

\section{Mode Shares}

In the intercept survey, we had one surveyor at each entrance to the development to ask people questions. We completed 428 valid surveys from 437 respondents. One question in the survey was what transportation mode was used to get to this development. The mode share from the intercept survey is presented in Table 2.3. We applied this mode share to the total trip-generation counts by entrance to compute the final weighted mode share. There is no sample for the residential south entrance or the parking garage street exit in the intercept survey. Therefore, the average mode share of the residential north and west entrances was applied to the residential south entrance, and the mode share of the parking garage was applied to the parking garage street exit.

The final mode share for Redmond TOD is 19 percent walk, 2 percent bike, 13 percent transit, and 65 percent auto (Table 2.3). According to the 2014 Puget Sound regional household travel survey, the regional mode share is 11 percent walk, 1 percent bike, 4 percent transit, and 82 percent auto (PSRC 2015). Compared with the regional mode share, Redmond TOD has significant mode shifts from auto to walk, transit, and bike. Redmond TOD has 1.7 times more trips made by walking and 3 times more trips made by transit than the regional average.

Table 2.3. Mode Shares in Redmond TOD

\begin{tabular}{|c|c|c|c|c|c|c|}
\hline \multicolumn{7}{|c|}{ Intercept survey } \\
\hline \multirow{2}{*}{ Entrance } & \multirow{2}{*}{ Count } & \multicolumn{5}{|c|}{ Mode share (\%) } \\
\hline & & Walk & Bike & Bus & Auto & Other \\
\hline Parking Garage & 115 & 2.61 & 1.74 & 0.87 & 93.04 & 1.74 \\
\hline Residential North & 90 & 21.11 & 2.22 & 65.56 & 10 & 1.11 \\
\hline Residential West & 124 & 54.03 & 0.81 & 9.68 & 34.68 & 0.81 \\
\hline Commercial (West) & 99 & 18.18 & 2.02 & 13.13 & 64.65 & 2.02 \\
\hline \multicolumn{7}{|c|}{ Trip generation counts } \\
\hline \multirow{2}{*}{ Entrance } & \multirow{2}{*}{ Count } & \multicolumn{5}{|c|}{ Count for modes } \\
\hline & & Walk & Bike & Bus & Auto & Other \\
\hline Parking Garage & 852 & 22 & 15 & 7 & 793 & 15 \\
\hline Residential South & 173 & 65 & 3 & 65 & 39 & 2 \\
\hline Residential North & 145 & 31 & 3 & 95 & 15 & 2 \\
\hline Residential West & 324 & 175 & 3 & 31 & 112 & 3 \\
\hline Commercial (West) & 446 & 81 & 9 & 59 & 288 & 9 \\
\hline Parking Garage Street Exit & 41 & 1 & 1 & 0 & 38 & 1 \\
\hline Final mode share & 1,981 & $18.93 \%$ & $1.67 \%$ & $13.01 \%$ & $64.85 \%$ & $1.54 \%$ \\
\hline
\end{tabular}

\section{Trip Generation}

Our actual trip-generation counts from the survey did not distinguish residential trips and commercial trips. To compare the actual trip generation with ITE's benchmarks, we combine all estimated trips for different uses into a total that can be compared to ITE. 
There were 1,981 person trips and 661 vehicle trips observed for the whole day of the survey. Those trips were generated by the occupied residential units, which are 312 units (322 units*0.969 occupancy rate), and leased commercial spaces, which are 1,905 square feet for an office, 2,682 square feet for a restaurant, and 2,081 square feet for an animal hospital.

To determine a trip-generation rate for the residential building at Redmond TOD, we used the ITE Trip Generation Manual's value for "223 Mid-Rise Apartment," which is defined as "apartments (rental dwelling units) in rental buildings that have between three and 10 levels (floors)." The ITE manual reports a trip-generation rate for the peak hour but does not report a daily rate for mid-rise apartments. However, the ITE manual does report a daily trip-generation rate for all apartments ("220 Apartments"), so we used this rate to compute the daily trip-generation rate for mid-rise apartments. Here was the process: (1) the average daily vehicle trip-generation rate for "220 Apartments" is 6.65 per dwelling unit on a weekday, 0.55 per dwelling unit during the AM weekday peak hour, and 0.67 per dwelling unit at the PM weekday peak hour; (2) the average vehicle trip-generation rate for "223 Mid-Rise Apartment" is 0.35 per dwelling unit at the AM weekday peak hour and 0.44 per dwelling unit at the PM weekday peak hour; (3) the average daily vehicle trip-generation rate for "223 Mid-Rise Apartment" equals $6.65 *(0.35+0.44) /(0.55+0.67)$, which is 4.31 per dwelling unit.

For the trip-generation rate of the office at the Redmond TOD, we used " 715 Single Tenant Office Building" in the ITE Trip Generation Manual. The average daily vehicle trip-generation rate for this type of land use is 11.65 per 1,000 square feet gross area (GFA) on a weekday.

For the trip-generation rate of the restaurant at the Redmond TOD, we used "932 High-Turnover (SitDown Restaurant)" in the ITE Trip Generation Manual. The average daily vehicle trip-generation rate for this type of land use is 127.15 per 1,000 square feet GFA on a weekday.

For the trip-generation rate of the animal hospital at Redmond TOD, the ITE manual has a category "640 Animal Hospital/Veterinary Clinic" but only reports the average vehicle trip-generation rate for the PM weekday peak hour, which is 4.72 per 1,000 square feet GFA. "630 Clinic" is the closest analog to an animal hospital in the ITE manual that provides other trip-generation rates. For 630, the daily average vehicle trip-generation rate on a weekday is 31.45 per 1,000 square feet GFA, and the average vehicle trip-generation rate for the PM weekday peak hour is 5.18 per 1,000 square feet. Therefore, the average daily vehicle trip-generation rate for "640 Animal Hospital/Veterinary Clinic" therefore equals $31.45 *(4.72 / 5.18)$, which is 28.65 per 1,000 sq. $\mathrm{ft}$.

Based on the ITE's trip-generation rates, the Redmond TOD would be expected to generate 1,767 daily vehicle trips (Table 2.4). The number of observed vehicle trips on the survey day was 661, just 37.4 percent of the ITE's expected value. This is consistent with the findings from a District Department of Transportation (DDOT) study of 16 locations in Washington, D.C. (Weinberger et al. 2015).

Table 2.4. The Comparison of Daily Vehicle Trip Generation between ITE Guideline and Redmond TOD

\begin{tabular}{|c|c|c|c|}
\hline & Trip generation rate & Total units & Total daily trips \\
\hline ITE guideline & - & - & 1,767 \\
\hline 223 Mid-Rise Apartment & 4.31 & 312 & $1,344.72$ \\
\hline
\end{tabular}




\begin{tabular}{|l|l|r|r|r|}
\hline & 715 Single Tenant Office Building & 11.65 & 1,905 & 22.19 \\
\hline & 932 High-turnover (sit-down) restaurant & 127.15 & 2,682 & 341.02 \\
\hline & 640 Animal Hospital/Veterinary Clinic & 28.65 & 2,081 & 59.62 \\
\hline Redmond TOD & - & - & $\mathbf{6 6 1}$ \\
\hline
\end{tabular}

\section{Parking Generation}

Parking supply and demand recorded for the Redmond TOD project were compared to the number of parking stalls as well as occupancy rates from the 2010 ITE Parking Generation manual.

\section{Residential}

For the residential component in the ITE Parking Generation manual, "222 High-Rise Apartment" (rental dwelling units) are defined as units located in rental buildings that have five or more levels (floors) and most likely have one or more elevators. This is the best match for the five-story multifamily residential uses at the Redmond TOD. The average parking-supply ratio reported by ITE is 2.0 parking spaces per dwelling unit at central city sites that are not directly in a downtown area.

As shown in Table 2.5, the actual parking supply for the residential units at the Redmond TOD is 1.19 parking spaces per unit or 379 total, which is much lower than ITE's guideline (2.0 spaces per unit or 644 total).

The ITE average peak period parking demand from seven study sites is 1.37 vehicles per dwelling unit with a standard deviation of 0.15 , a range of $1.15-1.52$, an $85^{\text {th }}$ percentile value of 1.52 , and a $33^{\text {rd }}$ percentile value of 1.38. Besides the average rate, the ITE manual also provides the best-fit regression line for estimating total parked vehicles as a function of the total number of dwelling units:

$$
\mathrm{P}=1.04 \mathrm{x}+130
$$

Where $\mathrm{P}=$ parked vehicles and $\mathrm{x}=$ dwelling units

At 1:00 am on the survey day, the actual peak parking demand of the residential units at the Redmond TOD was 278 vehicles. That is much lower than both the ITE average of $427(1.37 * 322 * 0.969$, occupied units only) and the ITE regression estimate of $454(1.04 * 322 * 0.969+130$, occupied units only). The actual residential peak period parking demand at Redmond TOD is 65 percent $(100 * 278 / 427)$ of the ITE's average demand based on the average parking-generation rate and 61percent (100*278/454) of ITE's average demand based on the regression equation.

\section{Commercial}

There is a total of 11,470 square feet of leasable space for commercial uses at the Redmond TOD and 26 parking spaces for all commercial uses (not including eight on-street parking spaces and an on-street loading zone with capacity for two vehicles). The leased space includes 6,668 square feet for a family restaurant, an animal hospital, and a retail financial services establishment. We do not have separate parking supply and demand data for each of these three uses, so we treat them as a whole.

In the ITE Parking Generation manual, "932 family restaurant" is defined as a "high-turnover (sit-down) restaurant without bar or lounge facilities." The average parking-supply ratio at family restaurants is 14.3 
spaces per 1,000 square feet GFA. The average peak period parking demand is 10.6 vehicles per 1,000 square feet GFA during a typical weekday at a suburban location with a standard deviation of 5.42, a range of $2.59-21.78$, an $85^{\text {th }}$ percentile value of 16.3 , and a $33^{\text {rd }}$ percentile value of 7.4.

The ITE's guideline for the average parking-supply ratio for office buildings is 4.0 spaces per 1,000 square feet GFA. The average peak period parking demand is 2.84 vehicles per 1,000 square feet GFA during a typical weekday at a suburban location with a standard deviation of 0.73 , a range of $0.86-5.58$, an $85^{\text {th }}$ percentile value of 3.45 , and a $33^{\text {rd }}$ percentile value of 2.56 .

The average parking-supply ratio that ITE estimates for an animal hospital/veterinary clinic is 2.3 spaces per 1,000 square feet GFA. The peak period parking demand ratio is 1.6 vehicles per 1,000 square feet GFA based on a two-hour observation.

According to the ITE guideline, the parking supply for the three leased commercial spaces at Redmond TOD would be 51 stalls $([14.3 * 2682+4 * 1905+2.3 * 2081] / 1000)$. The actual parking supply for commercial uses at the Redmond TOD is 26 total stalls for all 11,740 square feet of commercial space. We cannot know precisely the actual parking supply just for the leased commercial space, but it would be about 57 percent of the total stalls based on the percentage of total floor area currently leased. That is to say, based on the current leases, about 14 stalls might be associated with the currently leased commercial space. This is only about 27 percent of the ITE's guideline (as shown in Table 2.5).

According to the ITE's guideline, the average total peak period parking demand for the three leased commercial uses would be 37 stalls ([10.6*2682+2.84*1905+1.6*2081]/1000), only for leased spaces). The actual peak parking demand of the commercial uses at Redmond TOD was 12 occupied stalls in the evening on the survey day, which is less than one-third of ITE guideline.

Table 2.5. The Comparison of Parking Supply and Demand Between Redmond TOD Residential and ITE Guideline

\begin{tabular}{|c|c|c|c|c|}
\hline \multicolumn{5}{|c|}{ Residential } \\
\hline & \multicolumn{2}{|c|}{ Supply } & \multicolumn{2}{|c|}{ Peak period demand } \\
\hline & $\begin{array}{l}\text { Parking spaces } \\
\text { per unit }\end{array}$ & $\begin{array}{l}\text { Total parking } \\
\text { spaces }\end{array}$ & Vehicles per unit & $\begin{array}{l}\text { Total parked } \\
\text { vehicles }\end{array}$ \\
\hline $\begin{array}{l}\text { ITE guideline: } 222 \text { High- } \\
\text { Rise Apartment }\end{array}$ & 2.0 & 644 & 1.37 & 441 \\
\hline Redmond TOD Residential & 1.19 & 379 & 0.86 & 278 \\
\hline \multicolumn{5}{|c|}{ Commercial (occupied space only) } \\
\hline & \multicolumn{2}{|c|}{ Supply } & \multicolumn{2}{|c|}{ Peak period demand } \\
\hline & $\begin{array}{l}\text { Parking spaces } \\
\text { per } 1,000 \text { sq. ft. } \\
\text { GFA }\end{array}$ & $\begin{array}{l}\text { Total } \\
\text { parking } \\
\text { spaces }\end{array}$ & $\begin{array}{l}\text { Vehicles per } \\
1,000 \text { sq. ft. GFA }\end{array}$ & $\begin{array}{l}\text { Total } \\
\text { parked } \\
\text { vehicles }\end{array}$ \\
\hline ITE Guideline & - & 51 & - & 37 \\
\hline $\begin{array}{l}932 \text { High-Turnover (sit- } \\
\text { down) Restaurant }\end{array}$ & 14.3 & \multirow{3}{*}{ - } & 10.6 & \multirow{3}{*}{ - } \\
\hline 701 Office Building & 4 & & 2.84 & \\
\hline $\begin{array}{l}640 \text { Animal } \\
\text { Hospital/Veterinary Clinic }\end{array}$ & 2.3 & & 1.6 & \\
\hline Redmond TOD commercial & 3.14 & 14 & 1.8 & 12 \\
\hline
\end{tabular}




\begin{tabular}{|l|r|r|}
\hline \multicolumn{3}{|c|}{ Total } \\
\hline & Supply & \multicolumn{2}{c|}{ Peak period demand } \\
\hline ITE guideline & 695 & $289 * *$ \\
\hline Redmond TOD & 393 & 28 \\
\hline
\end{tabular}

*The peak parking demand of residential and the peak parking demand of commercial occur during different periods during a day. We cannot simply sum them to get a total peak parking demand.

**The most parked vehicles at the TOD for any one hour on the survey day.

In sum, the overall parking supply for the residential and occupied commercial space at Redmond TOD would be 695 spaces, according to ITE guidelines. The actual parking supply for the residential and occupied commercial space is 393 spaces, which is only 56 percent of ITE guideline. The actual peak parking demand of the residential and commercial uses at Redmond TOD was 289 occupied spaces for the one hour of the survey day with the most parked cars. This is 42 percent of the ITE supply guideline and 74 percent of the Redmond TOD's actual supply. We provide these last estimates to suggest what would be theoretically possible with shared residential and commercial parking.

\section{Parking Demands for Different Land Uses}

The parking demands for different land uses during the survey day are shown in Figure 2.4. The peak period of parking demand is different for each land use.

For the transit park-and-ride, demand was very high at midday. More than 90 percent of parking spaces were occupied from 8:00 a.m. to 3:00 p.m. The demand dropped down to less than 20 percent occupancy after 8:00 p.m.

Residential demand for parking peaked overnight, from 10:00 p.m. to 8:00 a.m. Demand started to decrease during the day and reached its lowest point between noon and 4:00 p.m., then started to increase again after 4:00 p.m.

Commercial demand for parking was low during day and increased after 6:00 p.m. Demand for commercial parking peaked at 10:00 p.m.

The peak period for transit parking was daytime, while the peak periods for commercial and residential parking were evening and night. Given this fact, there is a real opportunity for sharing parking spaces among these different uses, something which is not realized at present. 


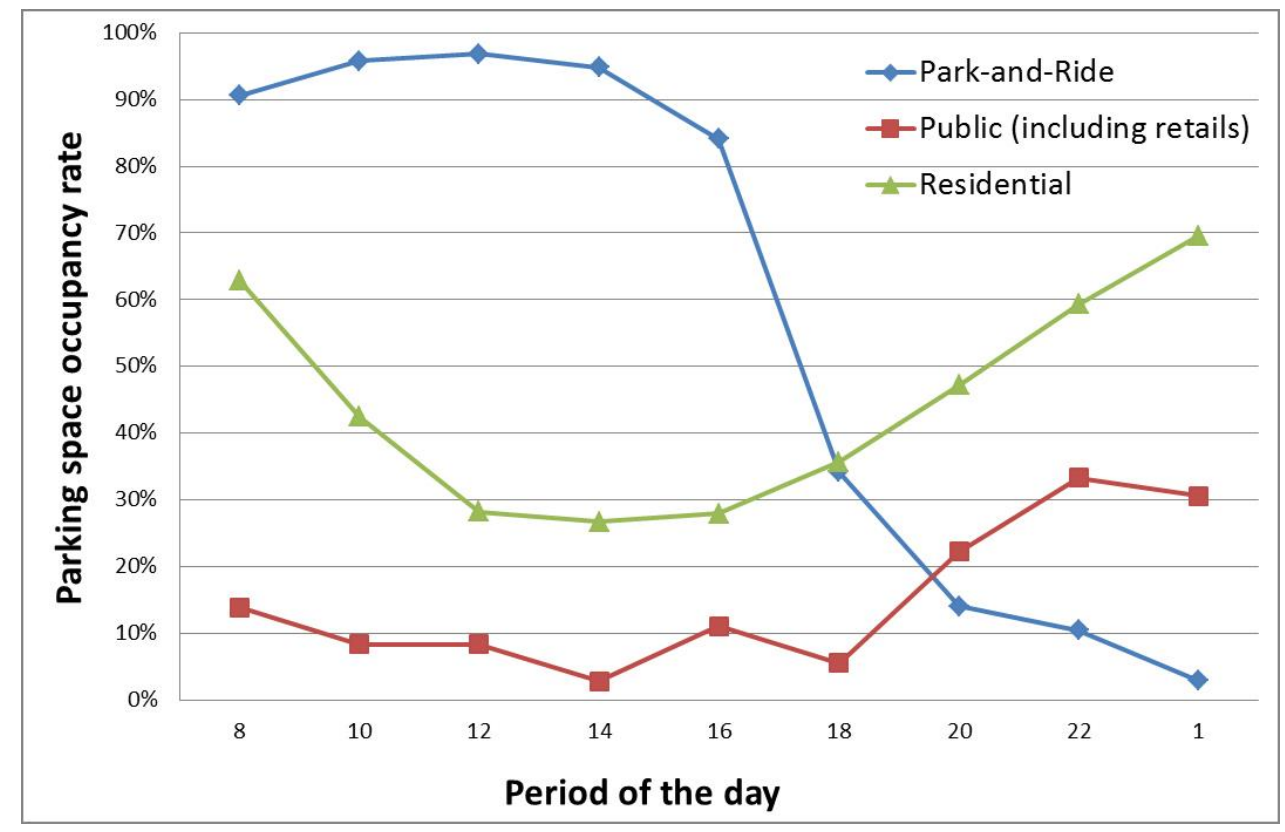

Figure 2.4. Parking Space Occupancy Rate for Different Uses at Redmond TOD

\section{Discussion}

Based on site visits already conducted, and a review of American Community Survey data, we expect that the vehicle trip and parking reduction may be even greater at other sites than at the Redmond TOD. This is because other TOD sites are more urban/less suburban than Redmond TOD, are more exemplary of TOD (being denser, more mixed, and more pedestrian-friendly), and are rail-served, unlike the Redmond TOD, which is bus served.

Still, the vehicle trip and parking reduction at the Redmond TOD site is impressive:

- Mode choices: Redmond TOD has 1.7 times more trips made by walking and 3 times more trips made by transit than the regional average.

- Trip and parking generation: Redmond TOD only generates about 37 percent of the vehicle trips estimated by ITE Trip Generation Manual. The actual residential parking demand at the Redmond TOD is only 65 percent of ITE's average. The actual commercial parking demand at the Redmond TOD is only 27 percent of the ITE average. This is due to mode shifts away from the automobile, and maybe to some degree to internal capture of trips within the mixed-use site.

- Shared parking potential: The peak period of transit parking is daytime, while the peak periods of commercial and residential were evening and night. There is a real opportunity for sharing parking spaces among these different uses, something which is not realized at present. 


\section{Chapter 3: Rhode Island Row TOD, Washington, D.C. Region ${ }^{3}$}

Rhode Island Row is a first-generation TOD located in the Brentwood Neighborhood in the Northeast portion of Washington D.C. Rhode Island Row was the first project in D.C. that sold itself as a TOD. This is the reason the development is categorized as a "first-generation TOD." It set a precedent for development that followed.

Brentwood is about three miles from the center of downtown D.C. The neighborhood is named after an estate that covered roughly the same geography before the turn of the $20^{\text {th }}$ century. Brentwood's population density is much lower than in the rest of the D.C. metropolitan area, with fewer than 5,000 people per square mile, compared to an average of nearly 10,000 people per square mile in D.C. as a whole. Historically, Brentwood has been a middle-class, African-American neighborhood, making it distinct in its racial makeup, with $82 \%$ African-American residents. The median household income is about $\$ 16,000$ lower than the rest of the city, and crime rates are higher.

The TOD is located adjacent to two big-box retailers and a large amount of surface parking, making it an isolated island in a sea of surface parking. However, beyond the immediately adjacent land uses is a main street in the midst of revitalization that gives the development its name. Rhode Island Avenue extends to the northeast of the TOD, coming to a mixed-use neighborhood with restaurants, coffee shops, a small local grocer, and residential and office space above the retail spaces. Many people travel to the neighborhood via the Metro, so the development is their first stop, making the TOD a welcome mat for the entire main street corridor.

Rhode Island Row has contributed to the revitalization of the neighborhood, in part by providing programming like live music, art, and holiday events, such as staged visits from Santa Claus. The development has brought a sense of place to the neighborhood and has been well received by the community, and not only in terms of its economic contributions. The development, its residents, and businesses have contributed to the social capital of the area by providing a new and lively pedestrian space with a mix of uses.

\footnotetext{
${ }^{3}$ For this case study, we conducted a number of interviews of key stakeholders. These included planners from the D.C. Office of Planning, the District Department of Transportation, and a community development coordinator from the Rhode Island Avenue Main Street organization. This process afforded us valuable qualitative data to provide detailed insight into the TOD, its development, and its significance in the context of the greater Washington, D.C. area.
} 


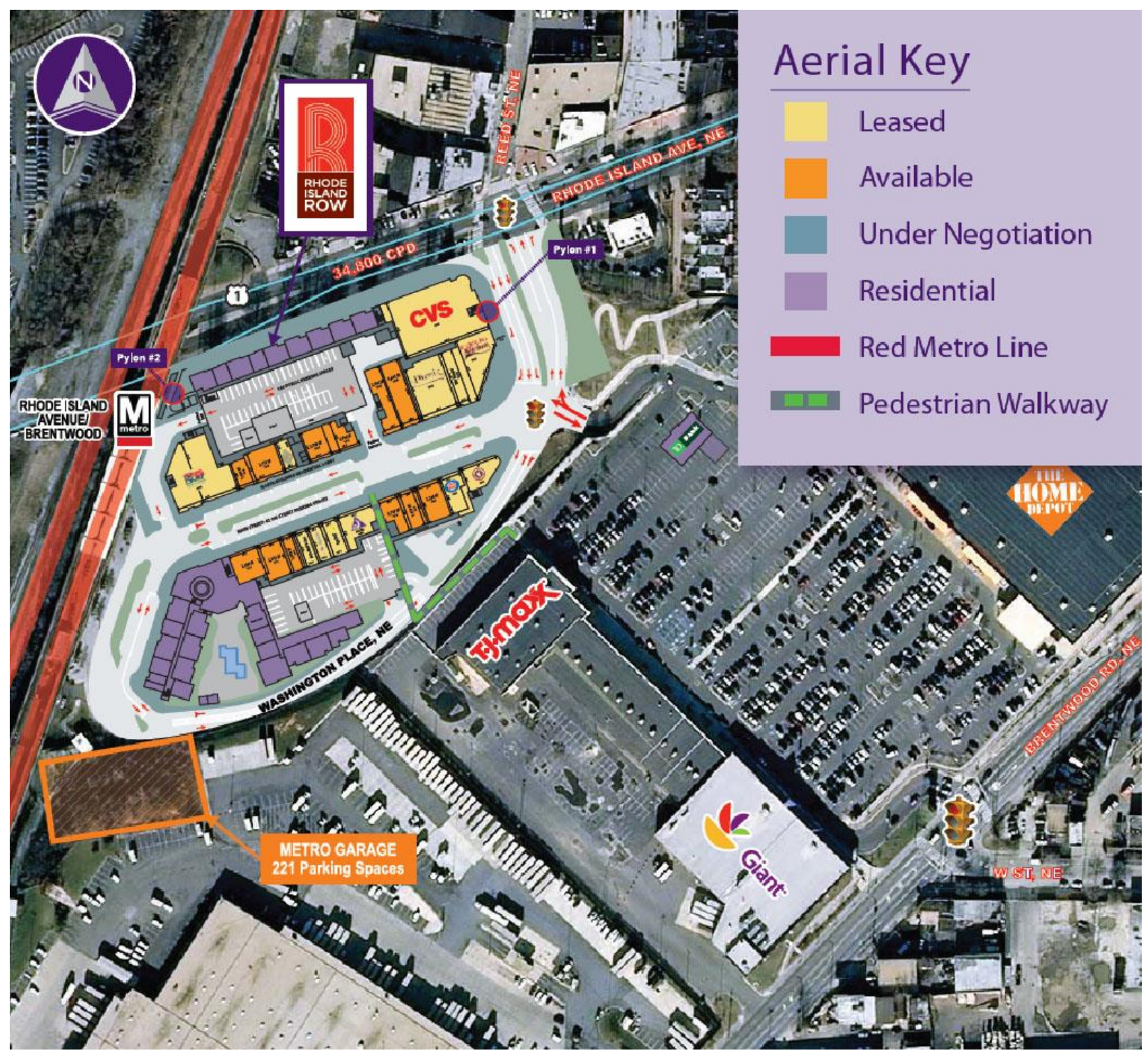

Figure 3.1. Geographic Context (source: http://hrretail.com/\#rhode-island-row)

\section{History}

Prior to the development of Rhode Island Row, the site was a surface parking lot for a Metrorail (Metro) subway station operated by the Washington Metropolitan Area Transit Authority (WMATA). The lot was owned by the city. In their application to amend the city's zoning map and receive preliminary approval of a planned unit development (PUD), the developers - A\&R Development Corporation and Mid-City Urban LLC - described their planned development as a TOD:

The proposed development will be a transit-oriented, mixed-use town center, and predominantly four to five stories in height. The design provides for retail stores on the ground floors oriented along a Main Street with apartments above and in separate buildings. Retail parking will be provided curbside along Main Street, and additional parking will be provided in two garages: one serving the residential apartments; and another serving retail as well as residential uses. 
Immediately to the south of the mixed-use PUD, the Applicant will construct another parking garage for WMATA to replace the parking for Metrorail customers that currently occupies the PUD site.

The rezoning application generated a good deal of opposition from neighborhood residents. The primary concern was parking. Residents feared that removing the park-and-ride lot would lead to commuters taking up limited on-street parking spaces. A public hearing was held so residents could discuss concerns about the rezoning and subsequent development. At this hearing, the issues of existing crime, the perceived potential for new crime brought about by lower-income residents of the development, and the potential impact on the stable older neighborhoods were all highlighted. However, the councilmen and zoning commission recognized the provision of affordable housing as a benefit. The area was rezoned to $\mathrm{C} 2 \mathrm{~B}$, which is a mixed-use commercial zone that incentivizes residential development.

\section{Transit Connection}

A development of this intensity would not be feasible without a strong connection to transit. Rhode Island Row is located along the nation's second most heavily traveled rail system. The Rhode Island Avenue stop was part of the first section of the Metro system completed in 1976, which is now referred to as the Red Line. The development is situated at the Rhode Island Avenue-Brentwood Metro stop. The Red Line offers varying headways, from three to eighteen minutes, with the most frequent service provided during the weekday morning rush. These short headway times provide exceptional destination accessibility and contribute an excellent alternative to automobile transport.

However, Metro is not the only transportation mode serving Rhode Island Row, and it is in fact a multimodal hub. The first components of the built environment that one encounters leaving the train platform and descending to the ground level are the bus bays and the kiss-and-ride and taxi stops. There are a number of feeder buses that serve the rail station, and it is the terminus of a number of additional bus lines. The roadways within the development are designed in a loop to facilitate efficient vehicle circulation as buses, taxis, and personal vehicles drop off and pick up transit riders. 


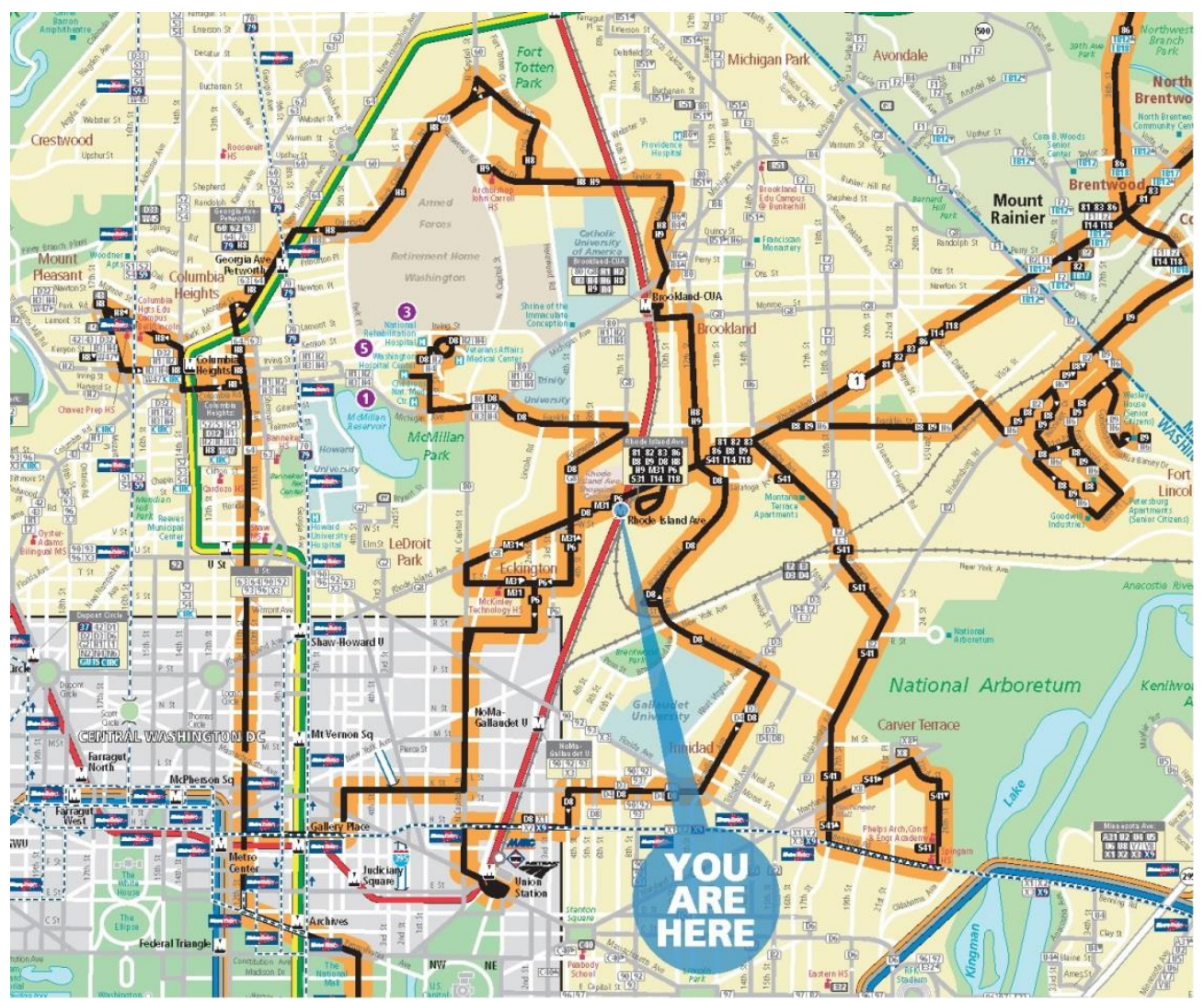

(a) Bus Network Accessible at Station

\begin{tabular}{|c|c|c|c|c|c|c|c|c|c|}
\hline \multicolumn{4}{|c|}{ All trequencies in this table are shown in minutes; check schedules for full details. } & \multicolumn{3}{|c|}{ Monday to Friday } & \multirow{2}{*}{\begin{tabular}{|c|} 
Saturday \\
Day \\
\end{tabular}} & \multirow{2}{*}{$\begin{array}{c}\text { Sunday } \\
\text { Day }\end{array}$} & \multirow{2}{*}{$\frac{\text { Fri/Sat }}{\begin{array}{c}\text { Late } \\
\text { Night }\end{array}}$} \\
\hline Bus Bay & $\begin{array}{l}\text { Take } \\
\text { Route DESTINATION }\end{array}$ & Serving & $\begin{array}{l}\text { Operator } \\
\text { Code }\end{array}$ & $\begin{array}{c}\text { AM } \\
\text { Rush }\end{array}$ & Midday & $\begin{array}{c}\text { PM } \\
\text { Rush }\end{array}$ & & & \\
\hline \multirow{4}{*}{ A } & 81 CHERRY HILL PARK & Rhode Isand Ave, Greenbelt [M & Metro & -- & - & - & - & 60 & - \\
\hline & 82 MT RAINIER & Rhode Is sand Ave to 34th St & Metro & -- & -- & $15-30$ & 30. & 30. & 30 \\
\hline & 83 CHERRY HILL PARK & College Park-U of Md [W & Metro & $15-30$ & 30 & 20 & 60 & -- & - \\
\hline & 86 CALVERTON & $\begin{array}{l}\text { Prince George's Plaza M, } \\
\text { College Park-U of Md (M) }\end{array}$ & Metro & $25-30$ & 60 & 30 & 60 & 60 & -- \\
\hline \multirow[t]{2}{*}{ B } & M31 McKINLEY HIGH SCHOOL & $\begin{array}{l}\text { School days only } \\
\text { Rhode Isand Ave, TSt }\end{array}$ & Metro & 4 trips & - & - & - & -- & -- \\
\hline & P6 ANACOSTIA M & Eckington, Metro Center M, M St & Metro & $15-20$ & 20 & $15-20$ & 30 & $30-35$ & -- \\
\hline \multirow{3}{*}{ C } & DB UNION STATION W & Mt Olvet Rd, Montello Ave, KSt & Metro & $12-18$ & 15 & $10-20$ & 20 & 30 & 30 \\
\hline & D8 WASHINGTON HOSPITAL CENTER & Edgewood St, Franklin St & Metro & $12-18$ & 15 & 20 & 20 & 30 & 30 \\
\hline & S41 SPINGARN HIGH SCHOOL & School days only & Metro & 1 trip & -- & -- & -- & -- & -- \\
\hline \multirow{2}{*}{ (D) } & T14 NEW CARROLLTON 田 & Rhode Isiand Ave, Good Luck Rd & Metro & $20-30$ & 60 & $20-25$ & 60 & 60 & -- \\
\hline & T18 NEW CARROLLTON M & Rhode Isand Ave, Annapolis Rd & Metro & $15-20$ & 30 & 20 & 30 & 45 & -- \\
\hline \multirow[t]{2}{*}{$\mathbf{E}$} & H8 MT PLEASANT & $\begin{array}{l}\text { Brookland-CUA M, } \\
\text { Georgia Ave-Petworth M, } \\
\text { Columbia Heights M }\end{array}$ & Metro & $9-15$ & $20-24$ & 12 & 20 & 25 & 34 \\
\hline & H9 JOHN CARROLL HIGH SCHOOL & School days only & Metro & 2 trips & -- & -- & -- & -- & -- \\
\hline \multirow[t]{2}{*}{ F } & $\begin{array}{ll}\text { B8 FORT LINCOLN } \\
\end{array}$ & $\begin{array}{l}\text { Rhode Isand Ave, Franklin St, } \\
\text { Eladersburg Rd }\end{array}$ & Metro & 10 & - & 13-20 & -- & -- & -- \\
\hline & B9 COLMAR MANOR & Phode Isand Ave, Frarklin St & Metro & -- & 60 & -- & -- & -- & -- \\
\hline
\end{tabular}

(b) Routes Servicing Rhode Island Row with Frequencies 


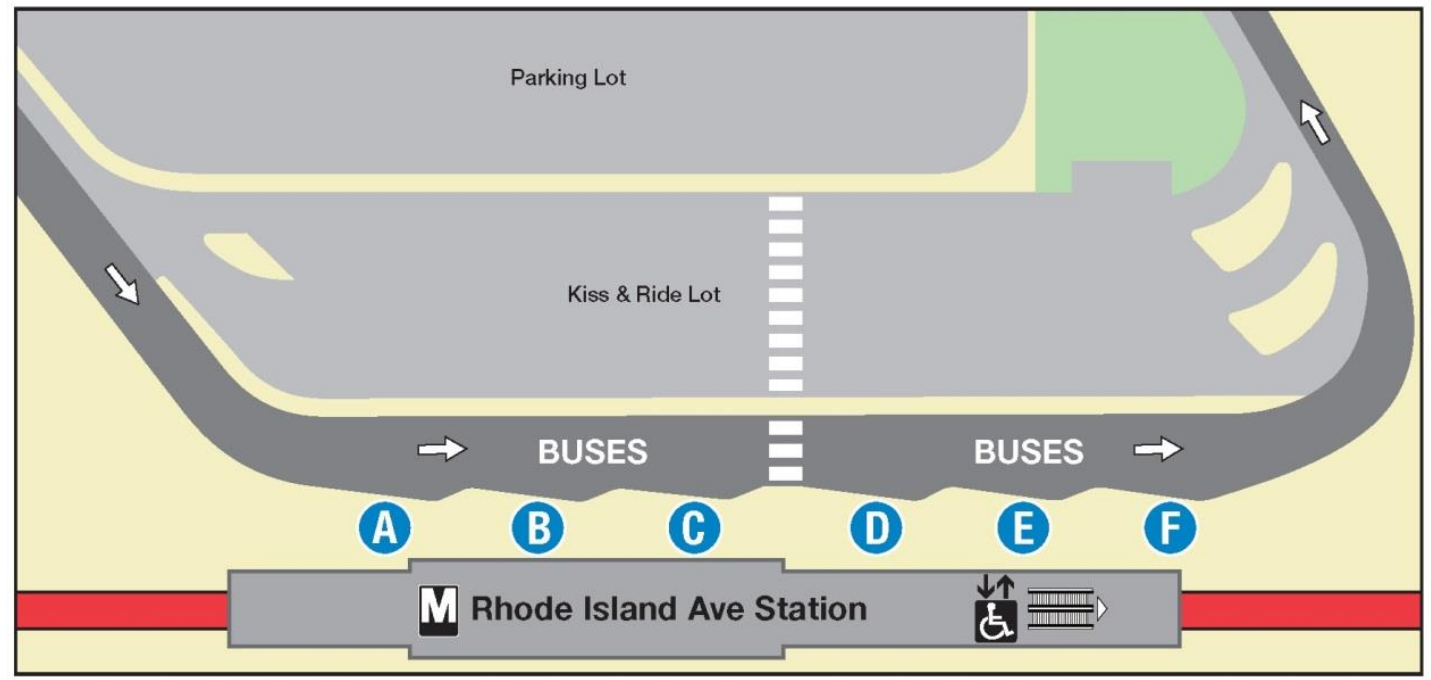

(c) Bus/Rail Interface

Figure 3.3. Rhode Island Row TOD: (a) Bus Network Accessible at Station; (b) Routes Servicing Rhode Island Row with Frequencies; (a) Bus/Rail Interface (source: www.wmata.com)

\section{The Development Itself}

The Rhode Island Row TOD has two buildings, a north building and a south building. The two buildings contain a mix of residential, retail, and office space. There are 272 apartment units, with 20 percent of the units being affordable to low- and moderate-income residents. In addition to residential units, there is nearly 65,000 square feet of retail space and approximately 11,000 square feet of office space.

Apartments at the TOD are 92 percent occupied, while the commercial spaces are approximately 65 percent occupied (see Table 3.1), with a preference for retail leases given to non-credit local businesses (see Table 3.2 for a list of current tenants).

The TOD also has three parking garages, one for the north building, one for the south building, and one exclusively for Metro users. The north parking garage is a five-level structure with 326 stalls, 135 of which are reserved for Metro park-and-ride. The remaining stalls are shared between commercial and residential users. The south parking garage is a three-level structure with 148 stalls, 47 of which are reserved for Metro park-and-ride. The remaining stalls are for residents. There are also 64 on-street parking spaces.

The original agreement between the developers, the zoning commission, planners, and the transit agency was that 50 percent of the parking available in the park-and-ride lot would be replaced. However, at some point, this was negotiated to replace the spaces one-for-one in a new structured parking garage on the southwest edge of the site.

Table 3.1. Development summary of Rhode Island Row TOD project ( 7 acres)

\begin{tabular}{|l|l|l|l|}
\hline Land uses & Description & Unit & Occupancy* \\
\hline Commercial & Ground floor & 70,985 square feet (sq. ft.) & $65.4 \%$ \\
\hline
\end{tabular}




\begin{tabular}{|l|l|l|l|}
\hline Residential & $\begin{array}{l}3 \text { stories above } \\
\text { commercial }\end{array}$ & $\begin{array}{l}\text { 274 units (149 units in north } \\
\text { building and 125 south } \\
\text { building) }\end{array}$ & $\begin{array}{l}\text { 92.0\% (135 units in } \\
\text { north building and } \\
117 \text { units in south } \\
\text { building) }\end{array}$ \\
Occupancy**
\end{tabular}

Note: * by September 16, 2015; **: the peak occupancy at September 16, 2015.

Table 3.2. Commercial Uses in Rhode Island Row

\begin{tabular}{|l|r|}
\hline Land uses & Unit (sq. $\boldsymbol{f t}$.) \\
\hline CVS & 13,545 \\
\hline Carolina Kitchen & 4,207 \\
\hline TKO Burger & 1,804 \\
\hline Phenix Salon Suites & 5,544 \\
\hline DC DMV & 9,642 \\
\hline Chipotle & 2,450 \\
\hline Jersey Mike's & 2,029 \\
\hline Sala Thai & 2,432 \\
\hline Sprint & 1,484 \\
\hline T-Mobile & 1,148 \\
\hline Arte Nail \& Spa & 1,148 \\
\hline Leasing Office & 1,000 \\
\hline
\end{tabular}




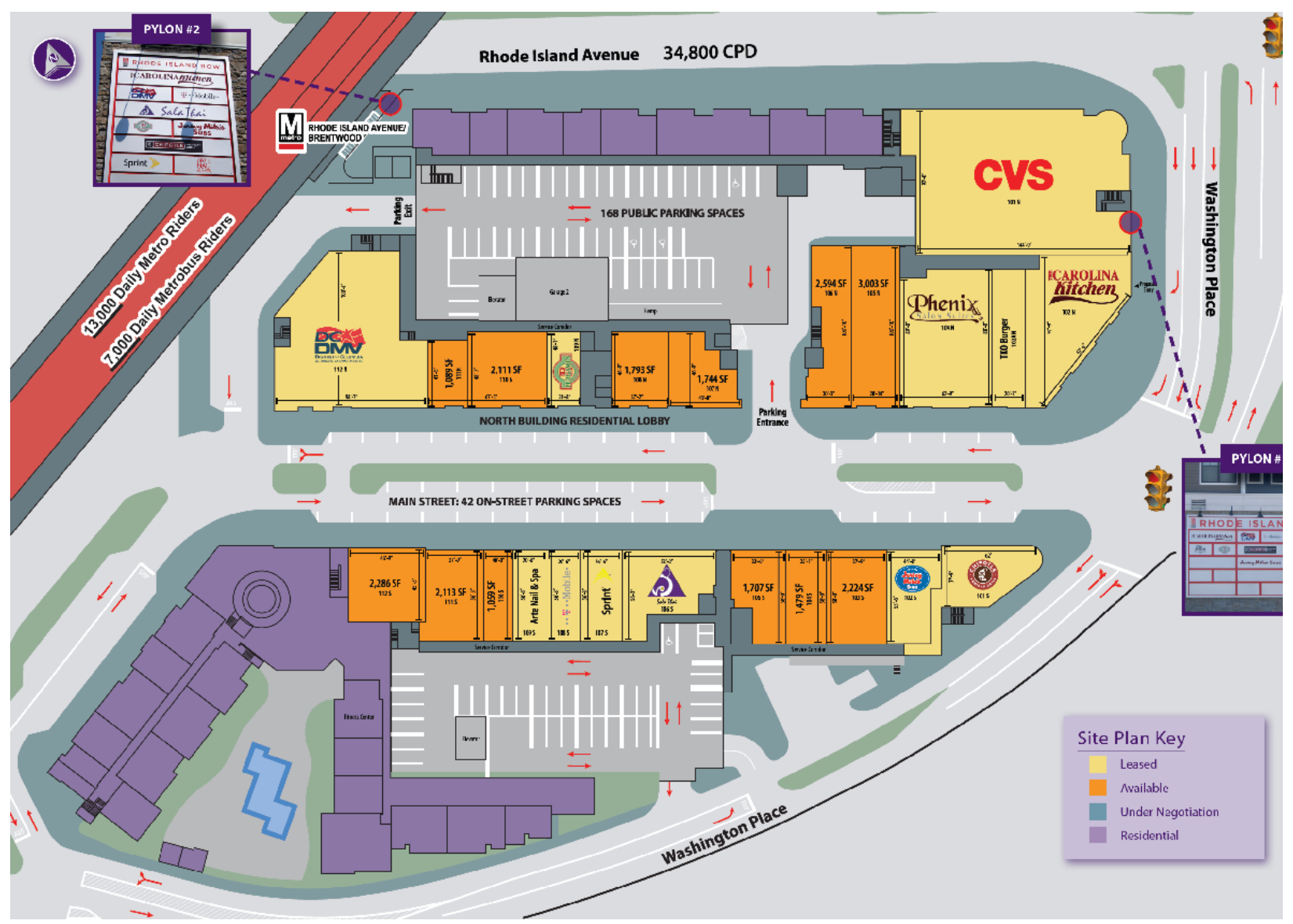

(a) Site Plan 


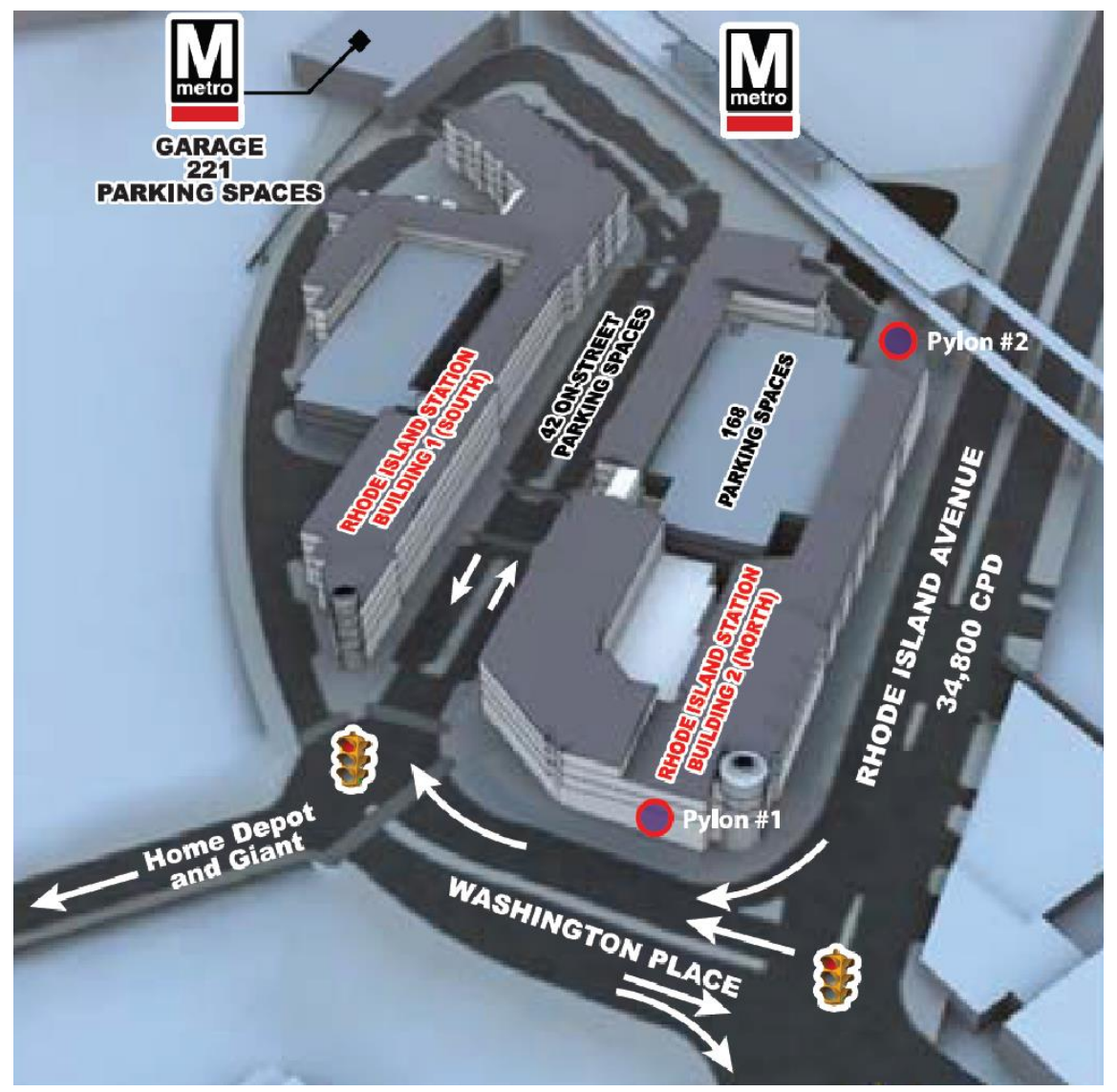

(b) Parking Supplies

Figure 3.2. Rhode Island Row TOD: (a) Site Plan; (b) Parking Supplies (source: www.wmata.com)

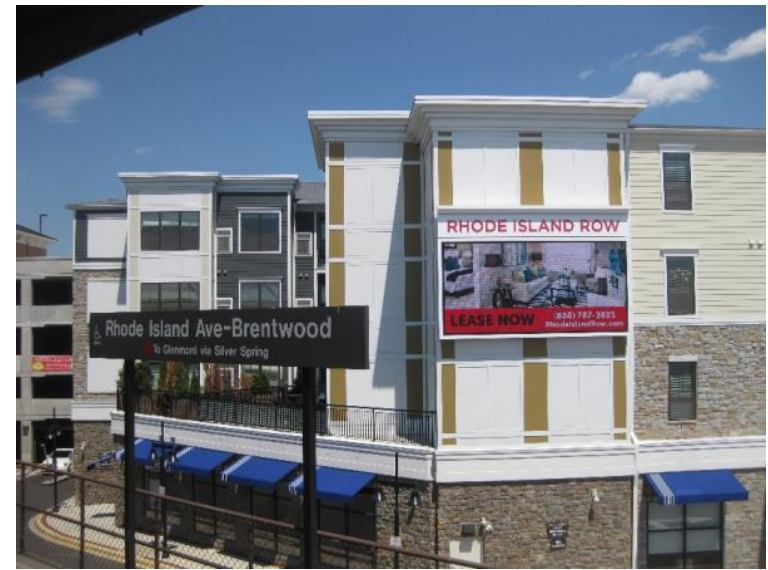

a) North building as seen from Metro platform

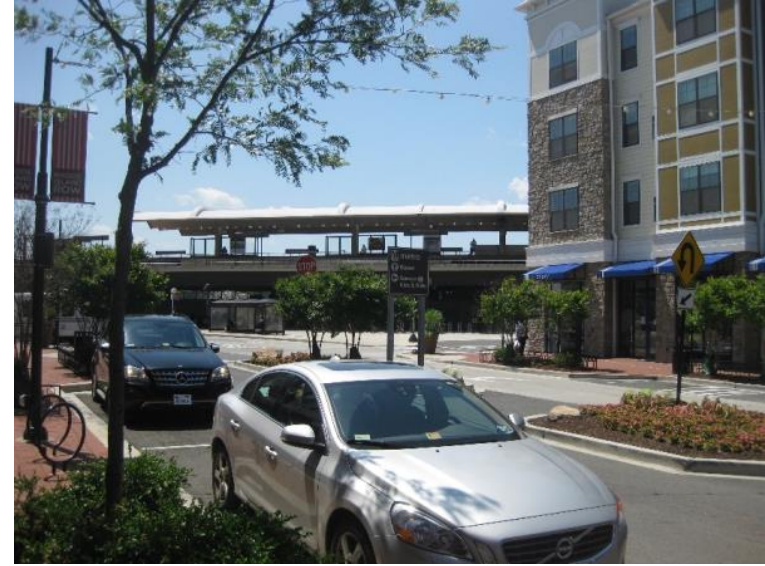

b) Metro platform and bus bays 


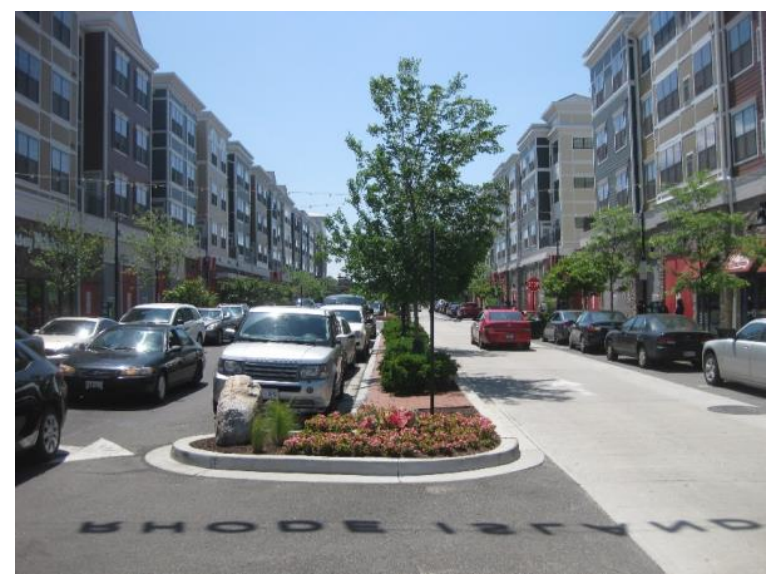

c) Traditional Main Street design

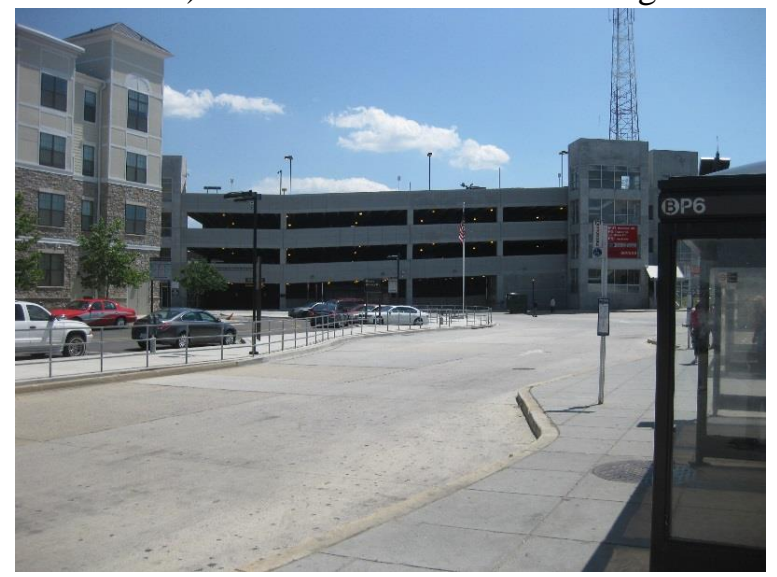

e) Metro park-and-ride structure

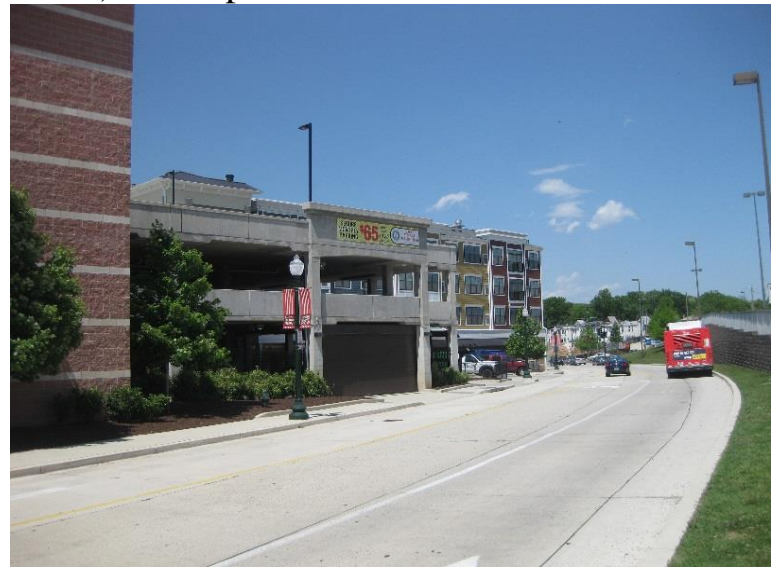

g) South parking garage

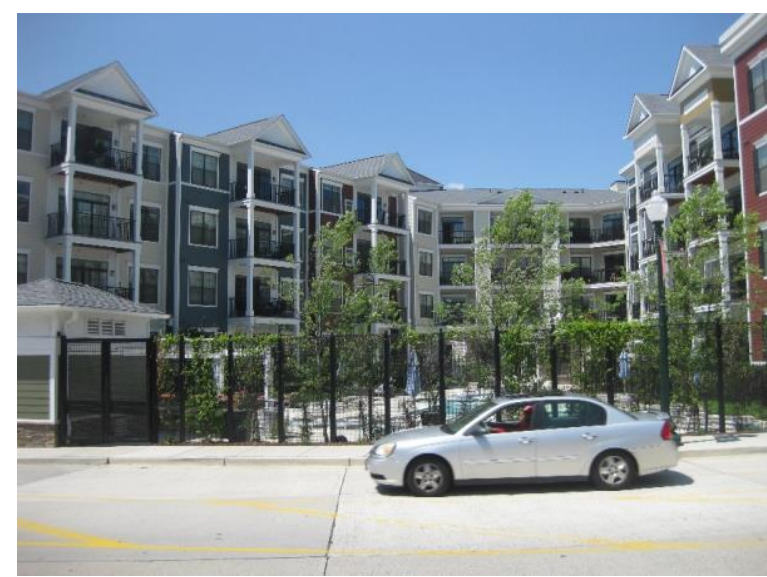

d) Multi-family housing

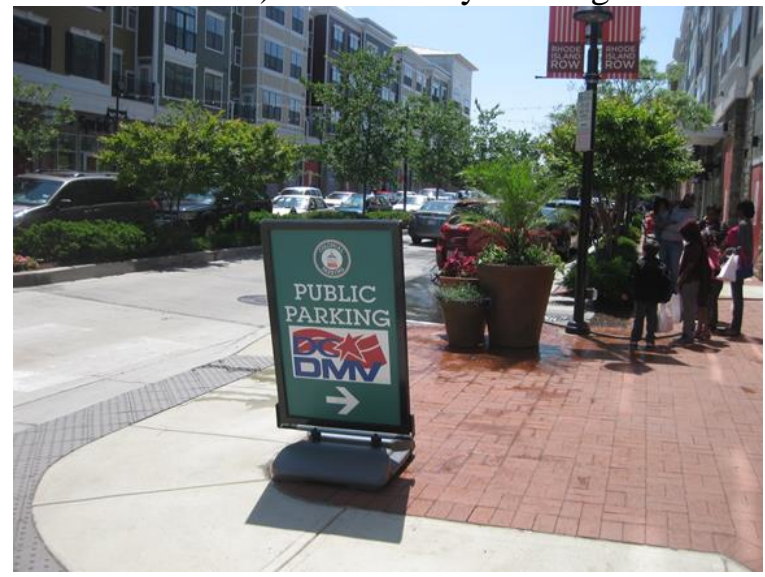

f) North garage entrance

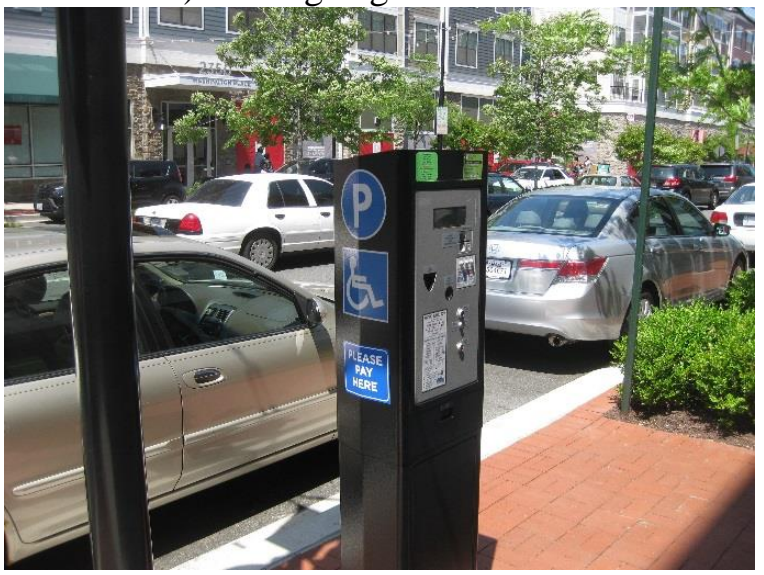

h) On-street paid parking 


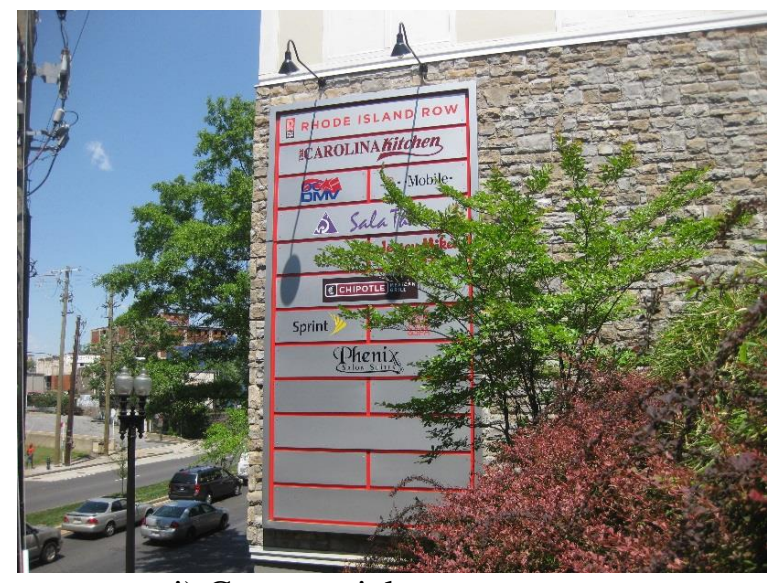

i) Commercial tenants

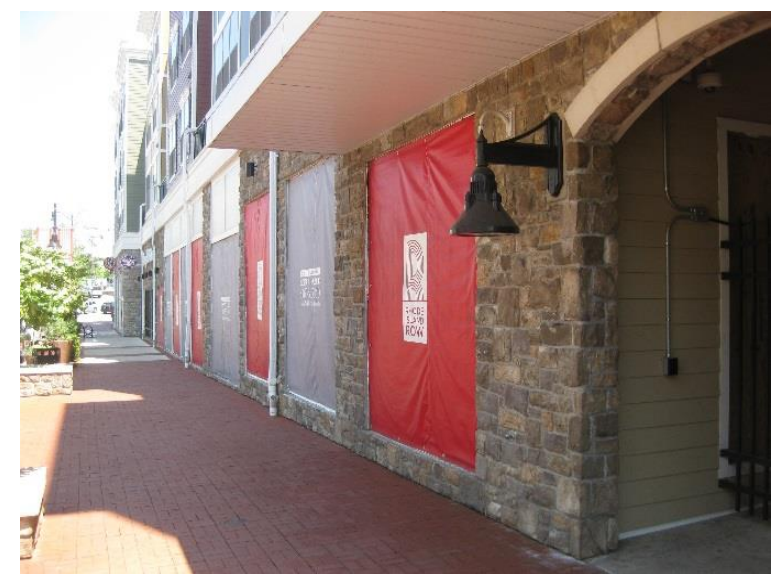

j) Unleased commercial space

Figure 3.4. Rhode Island Row TOD

\section{Impact on the Region}

Thanks to Rhode Island Row, TOD is considered a standard development typology in the D.C. area rather than an anomaly. A recent parking study in the District indicates that parking demand and utilization are far lower than previously established standards. Rogers et al. (2016) found an astonishingly low figure of 0.44 average observed parked cars per occupied housing unit. They also found that among multifamily housing structures surveyed, an average of 0.64 parking stalls were provided per housing unit. This figure is far below what was provided by Rhode Island Row. This shows a clear shift in parking supply provided by contemporary multifamily housing developments in a rapidly growing and densifying urban area. It also reflects a corresponding decline in demand for parking.

Many interviewees attributed the shift in the District's development standards to the success of Rhode Island Row. Although it has been acknowledged that Rhode Island Row does not exemplify every desirable design characteristic that has come to be expected of contemporary transit-oriented development, it has paved the way for new and improved projects that emulate Rhode Island Row. A brand new transit village is planned to be developed on the other side of the tracks, which will continue to make the area a hub for modern mixed-use development that provides on-site amenities while improving accessibility and reducing automobile reliance. The willingness of private enterprise to invest in land directly adjacent to Rhode Island Row also speaks to its continued success.

\section{Data Collection}

The multimodal transportation planning and engineering firm Fehr \& Peers developed a data collection plan and protocols, and managed data collection in the field and subsequent data entry for three types of travel data: (1) a full count of all persons entering and exiting the two buildings that make up Rhode Island Row, (2) a brief intercept survey of a sample of individuals entering and exiting the buildings, (3) parking inventory and occupancy counts of all off-street parking accessory to the commercial and residential uses of the buildings, and the co-located, but separately managed off-street parking facility owned and operated by Metro for all day use by transit riders, and (4) parking inventory and occupancy counts for on-street parking on Rhode Island Row's Main Street. 
The intent of this approach was to develop an accurate measure of total trip generation associated with the commercial and residential uses at the site, as well as complementary travel survey and parking utilization data that provide a picture of the mode of travel, origin/destination, parking location - if applicable - and purpose for all trips to and from the building throughout the course of the day.

All survey and trip count data were recorded on location in Rhode Island Row between 7:00 a.m. and 9:00 p.m. on Wednesday, September 16, 2015. The survey and trip count data were performed by temporary staff (two of whom were students) and professional counting staff from Quality Counts. Parking utilization was surveyed at each facility during this same period by Fehr \& Peers staff. In addition, an "overnight" count of parking occupancy was conducted at all three garages around midnight to determine parking occupancy during the anticipated period of peak utilization associated with the predominant residential use.

For the purpose of counting person trips generated and recording travel patterns, separate teams of surveyors were employed to (a) count people entering/exiting at each building entrance, and (b) conduct intercept surveys. All parking inventory and occupancy counts were conducted by Fehr \& Peers planning staff, who also supervised survey workers at building entrances.

Throughout the survey period, nine people were employed to conduct trip counts. These surveyors were stationed on the public sidewalk in fixed positions where they could easily and continuously observe primary entrances to the buildings and on-street parking locations. Care was taken to eliminate as much as possible double counting that could occur when pedestrians exited the parking garage then entered a commercial doorway or a pedestrian entered/exited a vehicle parked in an on-street stall then entered/exited a commercial doorway. Each counter observed nearby on-street parking to verify that individuals entering/exiting on-street parked vehicles accessed the commercial or residential doorways that he/she was responsible for. Individuals were counted as vehicles and not pedestrians in these circumstances. In addition, the counter ( $\mathrm{N} 3$ on the counter location map) located at the parking garage entrance for the north building observed pedestrians exiting the garage and, to the best of his ability, notified the other counters if the pedestrian entering their respective doorways came from the parking garage and therefore had been counted already at N3. Counters on the north, south, and west sides and the northeast corner of the building tallied the number of people entering and exiting each door by hour. The counter on the southwest corner recorded pedestrians entering/exiting the lone south door, in addition to people entering/exiting the Metro parking facility by bicycle, or motor vehicle - noting vehicle occupancy when visible.

It should be noted that even with all the care taken to eliminate over counting, this most likely occurred during peak times when numerous pedestrians were exiting the parking garage and could not be tracked to specific doorways. Additional confusion was created because Metro users are allowed to park in both the north and south garages, so some Metro-only users might have been counted mistakenly as Rhode Island Row users.

A separate team of surveyors - three all day - were employed to intercept and survey people entering and exiting the buildings. These surveyors were stationed to the south, west, and northeast of the north building and the north and south of the south building, covering primary pedestrian entrances to both 
buildings. The surveyors were instructed to leave their stations as necessary to intercept and attempt to survey individuals seen moving toward an entrance or away from a building exit.

As a first step, surveyors noted whether the subject was observed "coming" or "going" to/from the building, the type and location of entrance/exit used, and the time of intercept by checking a box on the data collection form associated with one of four 15-minute periods per hour.

People leaving the buildings were asked: (1) "How do you plan to get to your next destination?" (e.g., by what mode of travel?), and (2) What is the purpose of your trip? (e.g., "Going home," "Going to work," "Shopping," or "other").

People arriving at the buildings were asked: (1) "How did you get here?" (e.g., by what mode of travel?), and (2) What is the purpose of your trip? (e.g., "home-bound," "work-bound," "shopping," "workrelated," or "other").

Individuals who indicated that they had arrived or would be leaving by automobile were also asked where they had parked their vehicle (i.e., "on-street" or "in the garage").

Surveyors counted and attempted to intercept only individuals observed walking to or from an entrance to the buildings (or, in observation of the garage entrance, only drivers and passengers in vehicles entering/exiting the garage driveway to/from the public street). Individuals waiting for the train or bus, or walking between the rail station and other trip origins/destinations, including the Metro park-and-ride garage, were not counted or surveyed. 


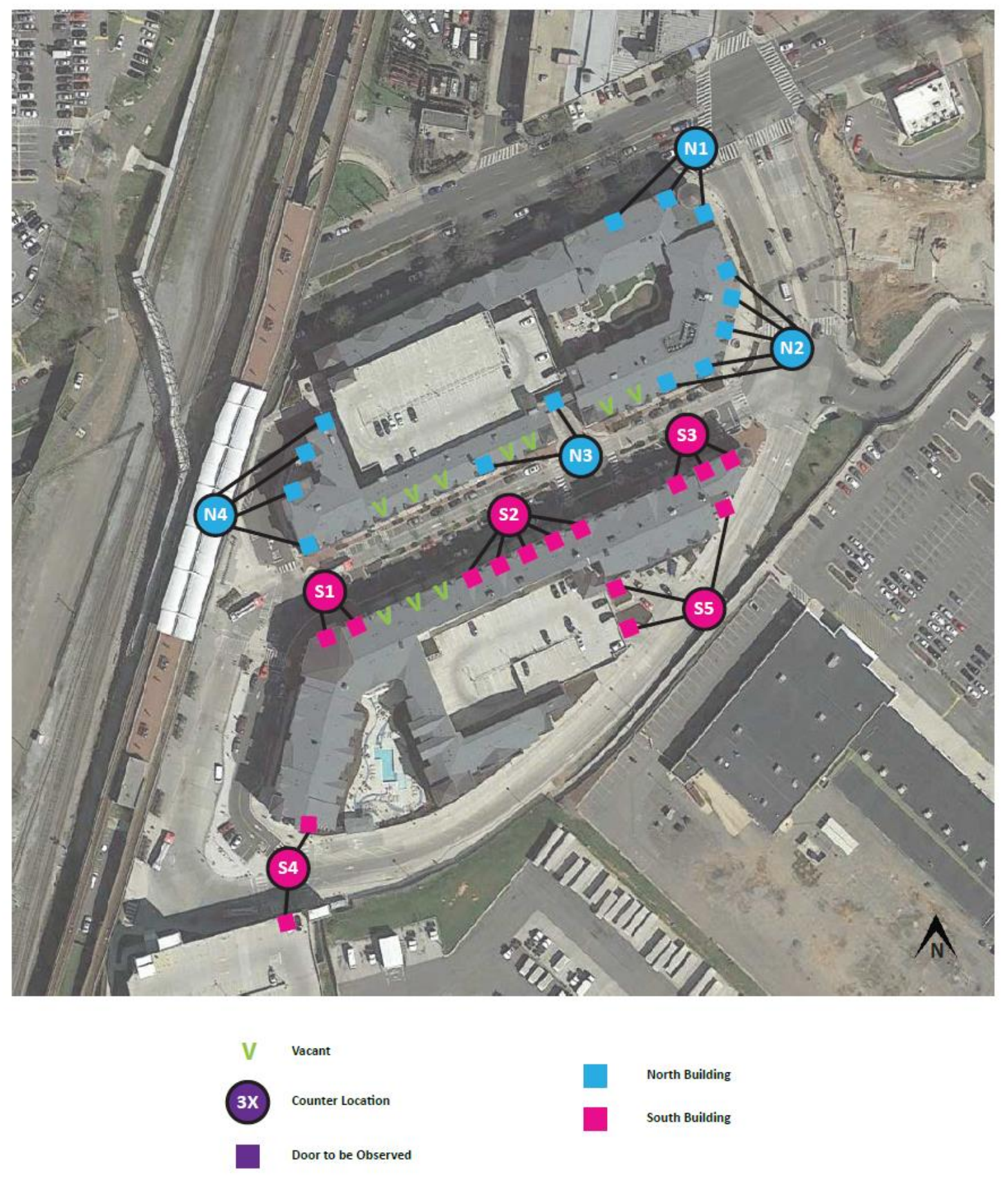

Figure 3.5. Rhode Island Row Counter and Survey Locations

Mode Shares 
In the intercept survey, we had surveyors at building entrances to ask people questions. We received 1,027 valid surveys from 1,047 respondents. One question in the survey was what transportation mode was used to get to/from this development. The mode share from the intercept survey is presented in Table 3.3. We then applied this mode share to the total trip generation counts by entrance to compute the final weighted mode shares.

The final mode shares for Rhode Island Row TOD are 17 percent walk, 0.3 percent bike, 9 percent bus, 27 percent rail, and 43 percent auto (Table 3.3). According to the 2008 Metropolitan Washington Council of Governments regional household travel survey, the regional mode share is 17 percent walk, 1 percent bike, 2 percent bus, 6 percent rail, and 70 percent auto. Compared with the regional mode share, Rhode Island Row TOD has a significant mode shift from auto to transit. Rhode Island Row TOD has about the same percent of walk trips as the regional average, 4.5 times the percentage of bus trips as the regional average, and 4.5 times the percentage of rail trips as the regional average.

Table 3.3. Mode Shares in Rhode Island Row TOD

\begin{tabular}{|c|c|c|c|c|c|c|c|}
\hline \multicolumn{8}{|c|}{ Intercept survey } \\
\hline \multirow[b]{2}{*}{ Entrance } & \multirow[t]{2}{*}{ Count } & \multicolumn{6}{|c|}{ Mode share (\%) } \\
\hline & & Walk & Bike & Bus & Rail & Auto & Other \\
\hline Residential North & 51 & 13.73 & 0.00 & 0.00 & 64.71 & 15.69 & 5.88 \\
\hline Residential South & 89 & 24.72 & 1.12 & 4.49 & 46.07 & 20.22 & 3.37 \\
\hline Commercial North & 545 & 14.31 & 0.00 & 13.58 & 22.57 & 45.69 & 3.85 \\
\hline Commercial South & 362 & 19.61 & 0.83 & 1.93 & 31.22 & 41.99 & 4.42 \\
\hline \multicolumn{8}{|c|}{ Trip generation counts } \\
\hline \multirow[b]{2}{*}{ Entrance } & Count & \multicolumn{6}{|c|}{ Count for modes } \\
\hline & & Walk & Bike & Bus & Rail & Auto & Other \\
\hline Residential North & 105 & 14 & 0 & 0 & 68 & 16 & 6 \\
\hline Residential South & 556 & 137 & 6 & 25 & 256 & 112 & 19 \\
\hline Commercial North & 5,263 & 753 & 0 & 715 & 1,188 & 2,405 & 203 \\
\hline Commercial South & 2,527 & 496 & 21 & 49 & 789 & 1,061 & 112 \\
\hline Final mode share & 8,451 & $16.57 \%$ & $0.32 \%$ & $9.33 \%$ & $27.22 \%$ & $42.53 \%$ & $4.02 \%$ \\
\hline
\end{tabular}

\section{Trip Generation}

Our actual trip generation counts from the survey did not distinguish residential trips and commercial trips. To compare the actual trip generation with ITE's benchmarks, we combine all estimated trips for different uses into a total that can be compared to ITE.

There were 8,451 person trips and 2,152 vehicle trips observed for the whole day of the survey. Those trips were generated by the 252 occupied residential units $(274 * 0.92)$ and 46,433 square feet of leased commercial space

For the trip-generation rate of the residential building at Rhode Island Row TOD, we used the ITE Trip Generation Manual's value for "223 Mid-Rise Apartment," which is defined as "apartments (rental dwelling units) in rental buildings that have between three and 10 levels (floors)." The ITE manual 
reports a trip-generation rate for the peak hour but does not report a daily trip-generation rate for mid-rise apartments. However, the ITE manual reports the daily trip-generation rate for all apartments (" 220 Apartments"). We use this rate to compute the daily trip-generation rate for mid-rise apartments. Here was the process: (1) the average daily vehicle trip-generation rate for "220 Apartments" is 6.65 per dwelling unit on a weekday, 0.55 per dwelling unit at the AM peak hour on a weekday, and 0.67 per dwelling unit at the PM peak hour on a weekday; (2) the average vehicle trip-generation rate for "223 Mid-Rise Apartment" is 0.35 per dwelling unit at the AM peak hour on a weekday and 0.44 per dwelling unit at the PM peak hour on a weekday; (3) the average daily vehicle trip-generation rate for " 223 MidRise Apartment" equals $6.65 *(0.35+0.44) /(0.55+0.67)$, which is 4.31 per dwelling unit.

For the trip-generation rate of the commercial uses at the Rhode Island Row TOD, we used the ITE Trip Generation Manual's values for "880 Pharmacy without Drive-Through" for the pharmacy, "932 HighTurnover (Sit-Down) Restaurant" for the restaurants, "918 Hair Salon" for the salon and spa, "731 State Motor Vehicles Department" for the DMV, "863 Electronics Superstore" for mobile phone stores, and "715 Single Tenant Office Building" for the leasing office. See details in Table 3.4.

Based on the ITE's trip-generation rates, the Rhode Island Row TOD would be expected to generate 5,808 daily vehicle trips (Table 3.4). The number of observed vehicle trips on the survey day was 2,017, only 34.5 percent of the ITE expected value. This is consistent with the findings from a District Department of Transportation (DDOT) study of 16 locations in Washington, D.C.

Table 3.4. The Comparison of Daily Vehicle Trip Generation between ITE Guideline and Rhode Island Row TOD

\begin{tabular}{|c|c|c|c|}
\hline & Trip generation rate & Total units & Total daily trips \\
\hline ITE Guideline & - & - & 5,808 \\
\hline 223 Mid-Rise Apartment & 4.31 & 252 & 1,086 \\
\hline 880 Pharmacy without Drive-Through & 90.06 & 13,545 & 1,220 \\
\hline $\begin{array}{l}932 \text { High-Turnover (Sit-Down) } \\
\text { Restaurant* }\end{array}$ & 127.15 & 12,922 & 1,643 \\
\hline 918 Hair Salon** & 19 & 6,692 & 127 \\
\hline 731 State Motor Vehicles Department & 166.02 & 9,642 & 1,601 \\
\hline 863 Electronics Superstore $* * *$ & 45.04 & 2,632 & 119 \\
\hline 715 Single Tenant Office Building & 11.65 & 1,000 & 12 \\
\hline Rhode Island Row TOD $* * * *$ & - & - & 2,017 \\
\hline
\end{tabular}

* 932 High-turnover (Sit-Down) Restaurant trip-generation rate has conservatively been applied to all five restaurants in Rhode Island Row, although three of them are fast-food restaurants without drivethrough windows. In the ITE Trip Generation Manual, 933 Fast-Food Restaurant without Drive-Through Windows has only one data point and an absurdly high trip-generation rate, 716 vehicle trips per day per 1,000 square feet of gross floor area. 934 Fast-Food Restaurant with Drive-Through Window is the better analog to the fast-food restaurants in Rhode Island Row, but the fast-food restaurants at Rhode Island Row do not have drive-through windows. According to the ITE Trip Generation Manual, such restaurants also have absurdly high trip-generation rates, averaging 496 vehicle trips per day per 1,000 square feet of gross floor area.

** 918 Hair Salon only provides peak hour trip-generation rates not daily rates. We have multiplied by 10 to convert from peak hour to daily trip generation, 10 being the typical ratio of peak to daily.

*** 863 Electronic Superstore has been applied to two mobile phone stores, T-Mobile and Sprint. It is the closest analog to mobile phone stores in the ITE Trip Generation Manual. 
**** The total vehicle trips we observed on the survey day were 2,152. Due to the shared parking between Rhode Island Row TOD and the Metro park-and-ride trips, some of the vehicle trips were generated by the Metro users. Based on the property manager's estimation, there were about 135 metro parkers per day. We subtracted these vehicle trips from the total vehicle trips for the TOD.

\section{Parking Generation}

Parking supply and demand recorded for the Rhode Island Row TOD project were compared to the number of parking stalls, as well as occupancy rates from the 2010 ITE Parking Generation manual.

\section{Residential}

The ITE Parking Generation manual defines "221 Low/Mid-Rise Apartment” (rental dwelling units) as units located in rental buildings that are up to four stories (floors) in height. This is the best match for the three-story multifamily residential uses at the Rhode Island Row TOD. The average parking-supply ratio reported by ITE is 1.4 parking spaces per dwelling unit at both urban and suburban sites.

For the ITE land use category 221: Low/Mid-Rise Apartment (urban location), the average peak period parking demand from 40 study sites is 1.20 vehicles per dwelling unit with a standard deviation of 0.42 , a range of $0.66-2.50$, an $85^{\text {th }}$ percentile value of 1.61 , and a $33^{\text {rd }}$ percentile value of 0.93 . Besides the average rate, the ITE manual also provides the best-fit regression line for estimating total parked vehicles as a function of the total number of dwelling units:

$$
\mathrm{P}=0.92 \mathrm{x}+4
$$

Where $\mathrm{P}=$ parked vehicles and $\mathrm{x}=$ dwelling units

Rhode Island Row has three parking garages, one for Metro park-and-ride, one for the north building, which is shared by residential and commercial users (with some spaces set aside for Metro park-and-ride), and one for the south building (with some spaces set aside for Metro park-and-ride). Because parking is shared in the north garage, we cannot isolate parking supply or demand for residential units in the north building. However, in the south building, most of the spaces are filled by residential users. Only one of three floors (the top floor) is shared by residential users and Metro park-and-ride.

The south garage has 148 spaces on three floors. A total of 47 spaces are reserved for Metro park-andride. As shown in Table 3.5, the actual parking supply for the residential units in the south building of the Rhode Island Row TOD (excluding Metro spaces) is 101 spaces total, or 0.81 parking spaces per unit (101/125), which is only slightly more than half of ITE's guideline of 1.4 spaces per unit.

The peak occupancy of parking spaces in the south garage occurs in the morning from 9:00-10:00 a.m. The number of spaces filled at that hour is 62 , for a peak occupancy rate of only 42 percent. It is reasonable to assume that many of the filled spaces at that hour are Metro parkers. The peak parking demand for residential users was in the early morning hours (12:10 a.m.). We can assume that there are no Metro parkers at that hour. The number of occupied parking spaces at the hour was 51 . The number of units in the south building is 125 units, 117 of which were occupied, for an occupancy rate of 94 percent. Thus, the peak residential parking demand relative to occupied units was 51/117 or 0.44 spaces per occupied unit, a very low peak demand ratio. The actual demand (51 spaces) was much lower than both 
the ITE estimate of 140 spaces $(1.20 * 117$, occupied units only) based on the average parking-generation rate and the ITE estimate of $112(0.92 * 117+4$, occupied units only) based on the regression equation. The actual residential peak period parking demand in the south building at Rhode Island Row TOD was only 36 percent $(100 * 51 / 140)$ of the ITE's average peak demand based on the average parking-generation rate and only 46 percent $(100 * 51 / 112)$ of ITE's average peak demand based on the regression equation.

\section{Mixed Use}

There are 70,985 square feet of leasable space for commercial uses at the Rhode Island Row TOD, of which 46,433 square feet were leased at the time of this study in 2015 . There are 149 apartments in the north building, 135 of which were occupied at the time of this study. Commercial users park in the north garage in spaces shared with residential users and Metro park-and-ride. Levels 1 and 2 are for residential and commercial users, level 3 is for residential, commercial, and Metro users, and levels 4 and 5 are for residential and Metro users. There are 326 spaces total, 237 of which are available for commercial and residential users. Commercial users also park on the street in front to the commercial uses themselves. There are 64 on-street parking spaces, 46 of which are effectively available to commercial users ( 4 of the 64 spaces are carshare spaces and 14 are Metro spaces). We do not have separate parking supply and demand data for each of these uses, so we treat them as a whole. The assumption is that residential users in the north building all park in the north parking garage. We know all the commercial users park in the north parking garage, since the south garage requires monthly parking passes.

Table 3.5 lists residential and commercial uses parking in the north garage and peak parking demands for the closest analogs in the ITE Parking Generation manual. Two of the restaurants in Rhode Island Row, Carolina Kitchen and Sala Thai, fall into the category of 932: High-Turnover (Sit-Down) Restaurant without Bar or Lounge Facilities. The average parking-supply ratio for these uses is 14.3 spaces per 1,000 square feet GFA. The average peak period parking demand is 5.55 spaces per 1,000 square feet GFA during the weekday at an urban location with a standard deviation of 2.69 , a range of $3.13-12.41$, an $85^{\text {th }}$ percentile value of 6.37 , and a $33^{\text {rd }}$ percentile value of 3.86 .

Other land uses in Rhode Island Row were similarly matched to land uses in the ITE Parking Generation manual. These uses are 933: Fast-Food Restaurant without a Drive-Through Window (three restaurants), 863: Electronic Superstore (the closest analog to the two mobile-phone stores), 730: Government Office Building (the closest analogue to the 731: state motor vehicle department), and 701: Office Building (the closest analogue to the leasing office). From ITE's Trip Generation Manual, a state motor vehicle department generates 2.4 times as many vehicle trips as a general government office building. Therefore, we will assume that the former generates 2.4 times the peak parking demand of the latter.

There is nothing comparable to hair salon in the ITE Parking Generation manual. One of our lessees falls into that category (Arte Nail \& Spa). "701: Office Building" is the closest analog to hair salon in the ITE Parking Generation manual (it is not a very good analog, but it is the best we can do and has a tripgeneration rate that is very similar). For 701, the parking supply rate is 4 spaces per 1,000 square feet GFA and the weekday peak parking demand rate is 2.47 vehicles per 1,000 square feet GFA. We have multiplied those rates by 1.29 to get the rates for hair salon, 1.29 being the ratio of the trip-generation rate (in weekday PM peak hour of generator) for "918: Hair Salon" to "701: Office Building”. So for hair 
salon, the parking supply rate is 5.18 spaces per 1,000 square feet GFA and the weekday peak parking demand rate is 3.18 vehicles per 1,000 square feet GFA.

According to the ITE manual, the parking supply for these mixed uses would be 466 spaces $(1.4 * 149+14.3 * 6.639+12.7 * 6.283+2.3 * 2.632+3.3 * 9.642+4 * 4.000+5.18 * 5.544)$. The actual parking supply at the Rhode Island Row TOD is 237 total spaces for all commercial uses and the north building residential. We cannot know precisely the actual parking supply just for the leased commercial space and the north building residential, but it would be less than 237 spaces. Therefore, the actual parking supply is at most about 51 percent of the ITE parking supply guideline (as shown in Table 3.5).

According to the ITE's guideline, the average total peak period parking demand for the commercial uses and the north building residential units would be 323 spaces

$(1.2 * 135+5.55 * 6.639+8.2 * 6.283+1.91 * 2.632+4.15 * 9.642+2.47 * 4.000+3.18 * 5.544)$ for just the leased commercial spaces. The actual peak parking demand of the commercial uses and the north building residential at Rhode Island Row TOD was 187 occupied spaces on the survey day, which is 58 percent of the ITE peak parking demand estimate.

Table 3.5. Comparison of Parking Supply and Demand between Rhode Island Row TOD and ITE Guidelines

\begin{tabular}{|c|c|c|c|c|}
\hline \multicolumn{5}{|c|}{ Residential } \\
\hline & \multicolumn{2}{|c|}{ Supply } & \multicolumn{2}{|c|}{ Peak period demand } \\
\hline & $\begin{array}{l}\text { Parking spaces } \\
\text { per unit }\end{array}$ & $\begin{array}{l}\text { Total parking } \\
\text { spaces }\end{array}$ & $\begin{array}{l}\text { Vehicles per } \\
\text { unit }\end{array}$ & $\begin{array}{l}\text { Total parked } \\
\text { vehicles }\end{array}$ \\
\hline $\begin{array}{l}\text { ITE guideline: } 221 \\
\text { Low/Mid-Rise Apartment }\end{array}$ & 1.4 & 191 & 1.20 & 126 \\
\hline $\begin{array}{l}\text { Rhode Island Row TOD } \\
\text { residential (south building) }\end{array}$ & 0.81 & 101 & 0.44 & 51 \\
\hline \multicolumn{5}{|c|}{ Mixed use (occupied space only) } \\
\hline & \multicolumn{2}{|c|}{ Supply } & \multicolumn{2}{|c|}{ Peak period demand } \\
\hline & $\begin{array}{l}\text { Parking spaces } \\
\text { per } 1,000 \text { sq. } f t . \\
\text { GFA }\end{array}$ & $\begin{array}{l}\text { Total parking } \\
\text { spaces }\end{array}$ & $\begin{array}{l}\text { Vehicles per } \\
\text { unit or } 1,000 \\
\text { sq. ft. GFA }\end{array}$ & $\begin{array}{l}\text { Total parked } \\
\text { vehicles }\end{array}$ \\
\hline ITE guideline & - & 466 & - & 323 \\
\hline \begin{tabular}{|l}
221 Low/Mid-Rise \\
Apartment
\end{tabular} & 1.4 & 208 & 1.20 & 162 \\
\hline $\begin{array}{l}932 \text { High-Turnover } \\
\text { (Sit-Down) } \\
\text { Restaurant without } \\
\text { Bar or Lounge } \\
\text { Facilities } \\
\end{array}$ & 14.3 & 95 & 5.55 & 37 \\
\hline \begin{tabular}{|l|}
933 Fast-Food \\
Restaurant without a \\
Drive-Through \\
Window \\
\end{tabular} & 12.7 & 80 & 8.20 & 52 \\
\hline $\begin{array}{l}863 \text { Electronic } \\
\text { Superstore }\end{array}$ & 2.3 & 6 & 1.91 & 5 \\
\hline $\begin{array}{l}730 \text { Government } \\
\text { Office Building }\end{array}$ & 3.3 & 32 & 4.15 & 40 \\
\hline
\end{tabular}




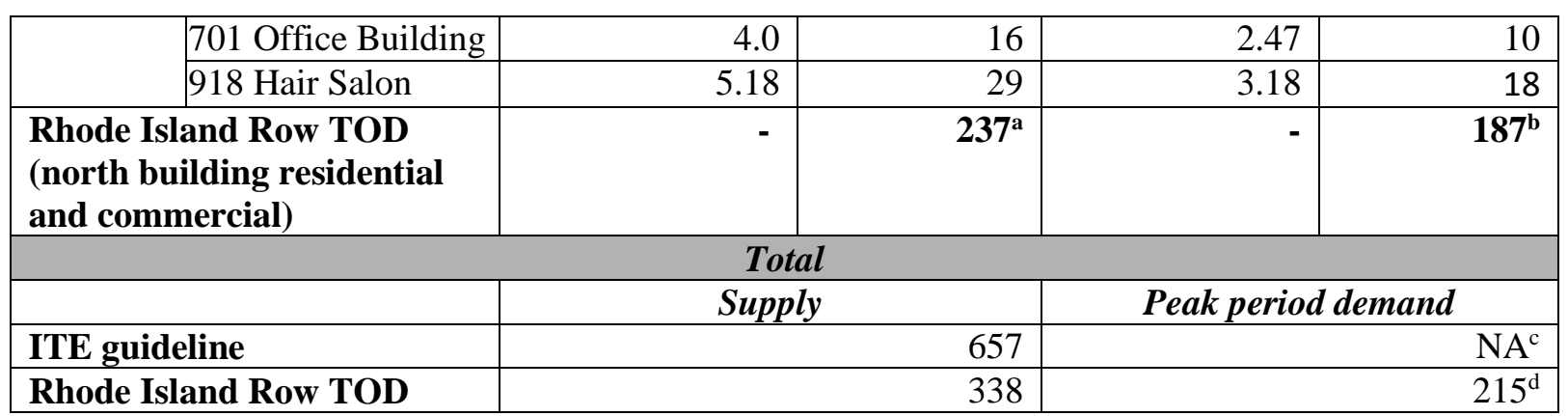

${ }^{a}$ This value is the sum of north garage parking spaces (326) plus on-street spaces (46) minus spaces in levels 3-5 reserved for Metro park-and-ride (135). This is overestimated by unknown amount. The actual parking supply for the occupied mixed uses should be less than this value.

${ }^{b}$ This value is the sum of north garage peak parking demand (242 occupied spaces at 1:40 p.m.) plus peak on-street parking demand (45 occupied spaces at 2:00 p.m.) minus Metro parkers (100 occupied spaces as estimated by the project Parking Manager).

${ }^{c}$ The peak parking demand of residential and the peak parking demand of commercial are different periods during a day. We cannot simply sum them to get a total peak parking demand.

${ }^{d}$ The most parked vehicles at the TOD for any one hour on the survey day.

In sum, the overall parking supply for residential and commercial users at Rhode Island Row TOD would be 657 spaces, according to ITE guidelines. However, the overall actual parking supply for the residential and commercial uses is 338 spaces, which is 51 percent of the ITE's guideline. The peak parking demand of the residential and commercial uses at Rhode Island Row was 215 occupied spaces for the one hour on the survey day with the most parked cars. This is only 33 percent of the ITE supply guidelines and 64 percent of the Rhode Island Row TOD's actual supply. We provide these last estimates to suggest what would be theoretically possible with shared residential and commercial parking.

\section{Parking Demands for Different Land Uses}

At the Rhode Island Row TOD, the Metro park-and-ride has its own parking structure. Parking garages in TOD itself are shared among residential, commercial, and Metro users. The parking demands for the Metro users and the development during the survey day are shown in Figure 3.6.

For the Metro park-and-ride, demands were very high at midday. More than 90 percent of the parking spaces were occupied from 9:00 a.m. to 3:00 p.m. The demands dropped quickly after that to around 30 percent occupancy after 8:00 p.m.

The TOD parking garage parking demands were also high at midday. More than 60 percent of the parking spaces were occupied from 9:00 a.m. to 2:00 p.m. Demand dropped to around 35 percent occupancy after 8:00 p.m.

Parking demand at both the Metro park-and-ride and the Rhode Island Row TOD parking garages are at their highest during the daytime. The TOD spaces vacated by residents during the day are filled by Metro parkers. However, we still donot see the full benefits of shared parking because many of the parking spaces in the two TOD garages are reserved for Metro parkers. This accounts for the fact that the parking occupancy rate for the two TOD garages never exceeds 68 percent. If there were true shared parking between TOD residents and Metro parkers, the peak occupancy rate would be higher. 


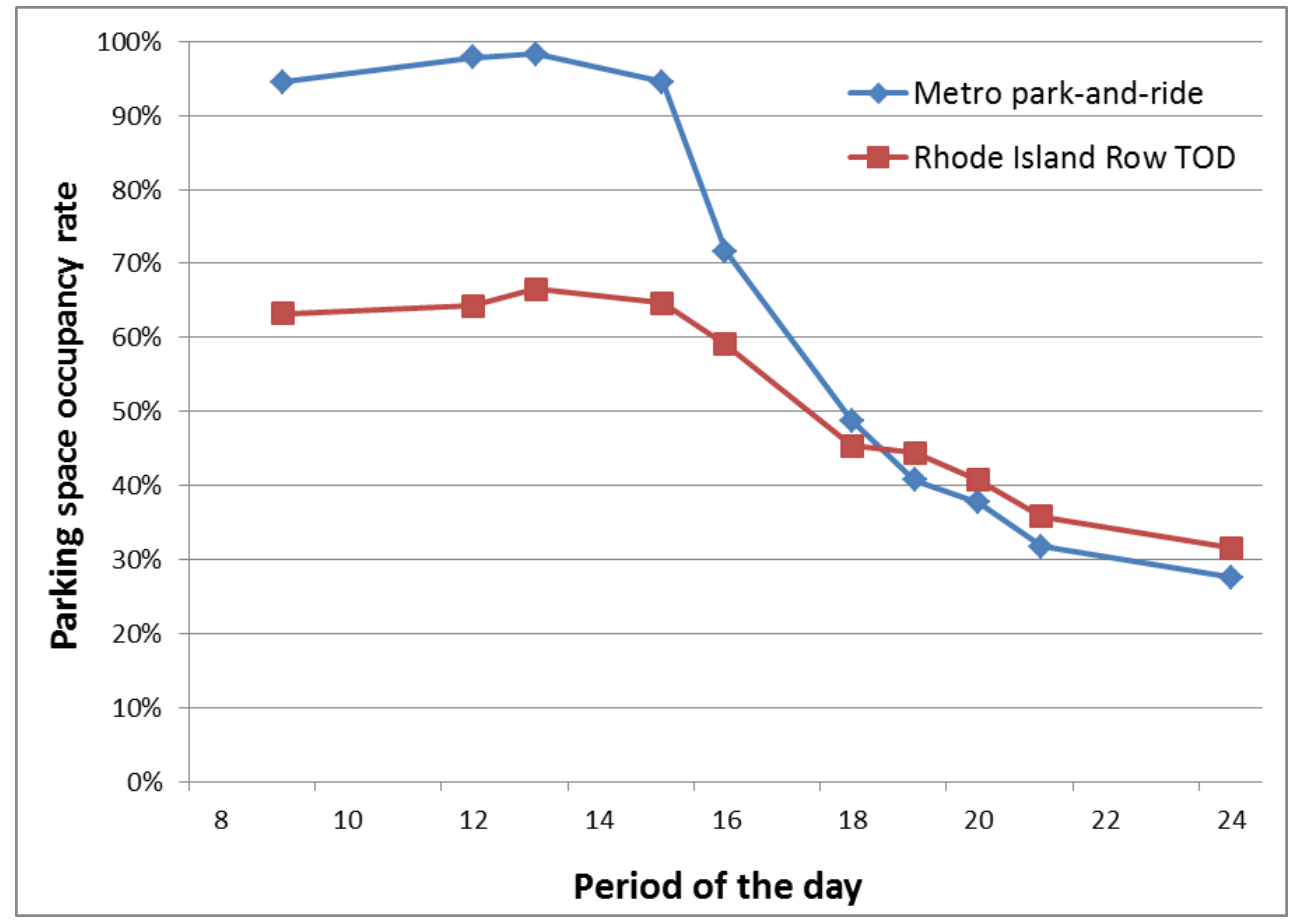

Figure 3.6. Parking Space Occupancy Rate for Different Uses at Rhode Island Row TOD

\section{Discussion}

Although figures differ somewhat, it is clear that Rhode Island Row experiences similar forces driving trip- and parking-generation rates as those at play at Redmond in the Seattle region. The reduction in vehicle trips observed at Rhode Island Row is remarkable, and very consistent with our findings at Redmond. Vehicle trips were 34.5 percent of estimates based on the ITE's Trip Generation Manual.

While mode shares for walk, bike, and bus were in line with D.C. regional averages, significant differences existed with rail and auto modes. The regional average for automobile mode share is 70 percent, but our team observed this mode to only make up just 43 percent of surveyed trips at Rhode Island Row. We deduce that this discrepancy in auto mode is attributable to the noticeably larger mode share of rail. Even in well-served Washington, D.C., the average regional rail mode share of 6 percent is miniscule in comparison to the 27 percent recorded by our survey.

The story is equally compelling with parking supply and occupancy rates at Rhode Island Row. The first dramatic findings are parking supply rates much lower than those suggested by ITE. For example, the south building provides just half of ITE's recommended parking supply. With such unprecedentedly low parking provision, one would expect high occupancy rates. While parking occupancies over 90 percent were observed at the midday peak in the Metro park-and-ride garage, the parking spaces available for other uses were nowhere near ITE's predicted peak-period demand. Similarly, the peak residential parking demand, determined on that day to be at 12:10 am, was found to be just 0.44 spaces per unit. This is only 36-46 percent of ITE's estimate, depending on which ITE method (regression equation or average parking-generation rate) is employed. However, shared parking opportunities are more limited than those suggested by varying peak periods at Redmond. 
The findings of the Rhode Island Row case study corroborate our findings from the first case study, Redmond. We see auto mode share replaced by transit, parking supply is well below ITE guidelines, and reduced parking supply has not produced shortages. In fact, parking-generation rates are so far below ITE estimates for developments of similar size and use that high parking vacancies are the norm for most hours at both TOD garages. 


\section{Chapter 4: Fruitvale Village TOD, San Francisco Region ${ }^{4}$}

Fruitvale Transit Village is a mixed-use development located at Fruitvale Station on the Bay Area Rapid Transit (BART) heavy rail system. The development is bordered by East 12th Street to the northeast, 33rd Avenue to the northwest, the BART tracks to the southwest, and 35th Avenue to the southeast. East 12th Street has many commercial establishments directly across from the TOD, including the Fruitvale Public Market.

The station platform spills passengers out into a pedestrian plaza. Retail businesses line the plaza, with numerous pedestrian amenities such as street trees, street furniture, water features, and wayfinding. Apartments sit above the retail uses, and offices back up to them. On the southeast side of the development, the last remnants of the original park-and-ride lot still remains. This sea of parking seems to stand out in an otherwise dense urban setting where buildings front the streets with very small setbacks. It serves as a land bank for the Phase II of the development.

Other case studies in this report show less than full occupancy rates for retail spaces, but all the residential and commercial spaces at Fruitvale were fully occupied at the time of this study in 2015. The norm is for residential units to rent out first, with commercial space lagging behind. The advantage of this case study is that the longer term trends of commercial occupancy can be examined. Fruitvale's developer and manager, The Unity Council, decided early on that local businesses were to come first when it came to renting retail space. In fact, an explicit policy states that only 20 percent of retail space may be rented to chain businesses and restaurants. This restriction made it a challenge to fill retail space at first. The configuration of retail and office space was also a handicap. Many of the businesses that initially showed interest found the transit village did not provide the same exposure they had grown accustomed to. However, more than a decade after the village was created, occupancy rates of all categories are much improved.

${ }^{4}$ For this case study, we interviewed Tiffany Wright of The Unity Council. 


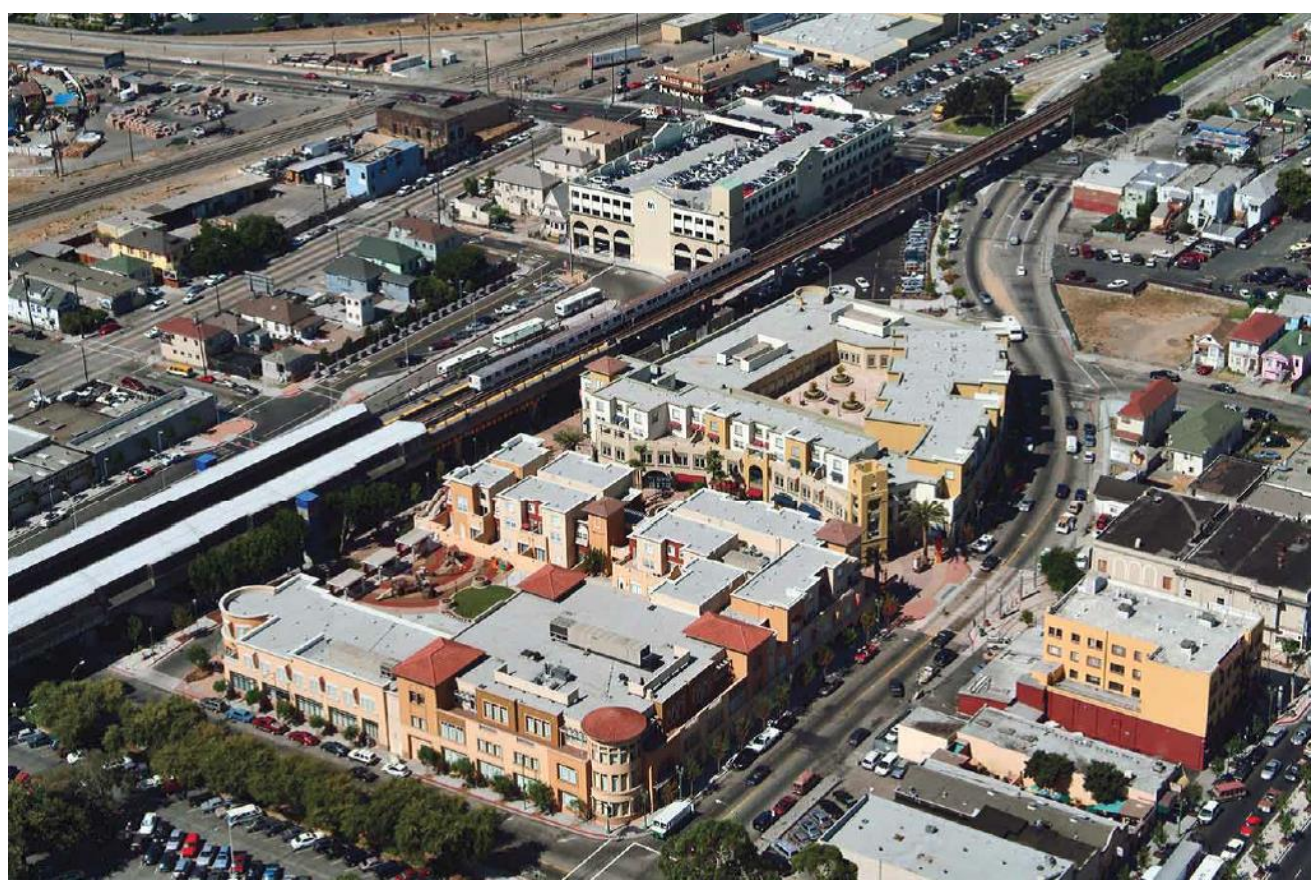

Figure 4.1. Aerial View of the Project

\section{History}

Fruitvale Transit Village is located in the Fruitvale District of Oakland, California. After the San Francisco earthquake of 1906, many African-American and Latino residents of the city relocated to West Oakland. During the mid-20 $0^{\text {th }}$ century, many of these neighborhoods fell victim to urban renewal, where large portions of major cities in the U.S. - usually inhabited by minorities - were cleared to make room for redevelopment and highways. This dispossessed minority population relocated once again to East Oakland, of which Fruitvale is the center.

The district was the home of the Bay Area's Chicano Movement in the late 1960s, and much of the transit village reflects this rich history. Partido Nacional de la Raza Unida is a political party primarily concerned with Chicano nationalism. The party saw a need for improved access to healthcare for the underserved Latino community, so they created a free clinic to serve their people. La Clinica de la Raza is the modern incarnation of this effort, and is one of the many tenants of Fruitvale Village.

BART owned two park-and-ride lots that were used mainly by suburban commuters to park for the day and ride BART into San Francisco. In 1991, there was talk of building a new parking structure to accommodate these suburban commuters. The local residents, frustrated with the decline of their neighborhood, voiced strong opposition to the proposal. The neighborhood had once been a vibrant shopping area but declined as local businesses lost market share to competing shopping centers in nearby suburbs. The Spanish Speaking Unity Council, a nonprofit community development corporation often referred to simply as The Unity Council, organized public opposition to the proposal. In response, BART withdrew its proposal. What ensued was a collaborative process, including local business owners, community leaders, BART, and local officials. The Unity Council saw the transit station as a valuable 
asset of the district that would leverage private investment in a transit village. This project would be "a catalyst for change," a template for future projects around the district.

Community groups were invited to take part in the planning and design of the new transit village. The Unity Council was awarded grants from the City of Oakland as well as the U.S. Department of Transportation, effectively making the council the official leader of the planning and design process. Beyond The Unity Council, the University of California at Berkeley, BART, the City of Oakland, the Metropolitan Transportation Commission, the Federal Transit Administration, the U.S. Department of Housing and Urban Development, and the U.S. Environmental Protection Agency were all involved. A design symposium was held, taking advantage of architectural and design expertise from UC Berkeley. The design team produced different site plans with input from workshop participants, especially community members. Finally, a meeting was held at which community members reached a consensus on a final site plan (Figure 4.2).

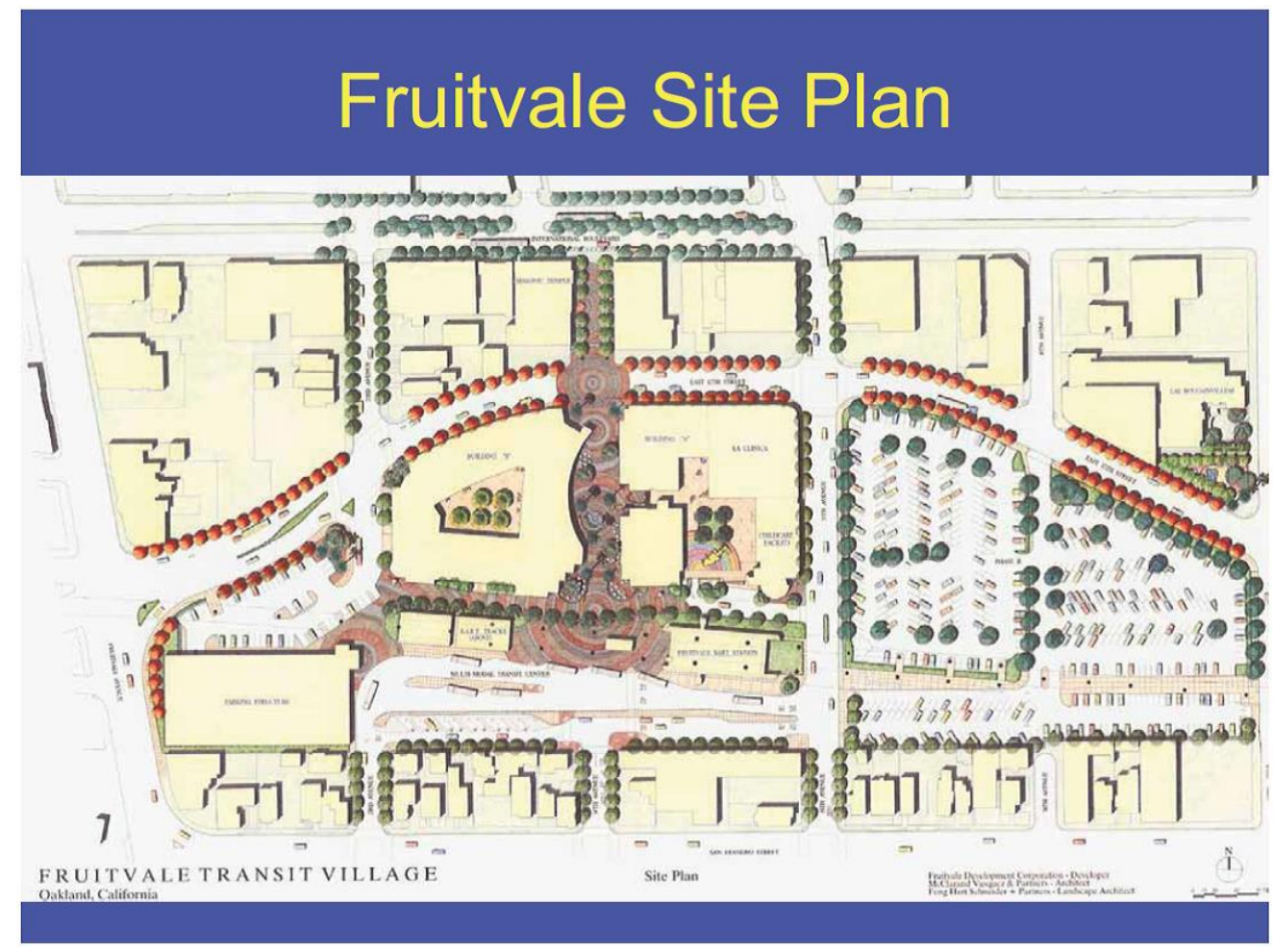

\section{Figure 4.2. Fruitvale Village Original Site Plan}

A case study by the Federal Highway Administration (FHWA) describes the transformation of the project to become something larger than could be administered by The Unity Council on its own:

As the scale of the Transit Village project continued to grow by leaps and bounds, the project's three central players decided to formalize their relationship. In 1994, The Unity Council, BART, and the City of Oakland signed a Memorandum of Understanding establishing the Fruitvale Policy Committee to guide further planning and development activities at the station. The Policy Committee was a very different approach to project development for BART and one of several ways that BART exhibited flexibility and innovation during the planning and design phase of the project. 
Beyond the memorandum of understanding and the Fruitvale Policy Committee (FPC), The Unity Council also created the Fruitvale Development Corporation (FDC) to act as the project developer. A competitive bidding process is the typical protocol of BART, but in this case, it was decided that The Unity Council would be the best entity to be granted development rights. Their ability to raise funds and facilitate an inclusive design process, and their stature within the community, were overriding considerations.

Specific agency policies at BART created challenges during the development process. One of these was BART's policy of retaining land ownership around stations for effective long-range planning. The FDC needed a large, contiguous piece of land to develop a feasible, coherent transit village, but most of the land on which the proposed development was to be built was held by BART. In order to loosely comply with their policy, BART agreed to a land swap that retained the value of their holdings while granting the FDC access to the land immediately adjacent to the station.

Parking supply was also a challenge. The land used for the transit village was a park-and-ride lot, and BART's policy was for one-to-one parking replacement anytime station parking spaces were given up for alternative uses. A solution was reached through an agreement between BART and Union Pacific, which owned an adjacent parcel. Union Pacific granted access to the land so that BART could build the originally proposed parking structure, but in a less prominent location with respect to the station (Figure 4.3). This was also made possible with a $\$ 7.4$ million grant from the Federal Transit Administration.

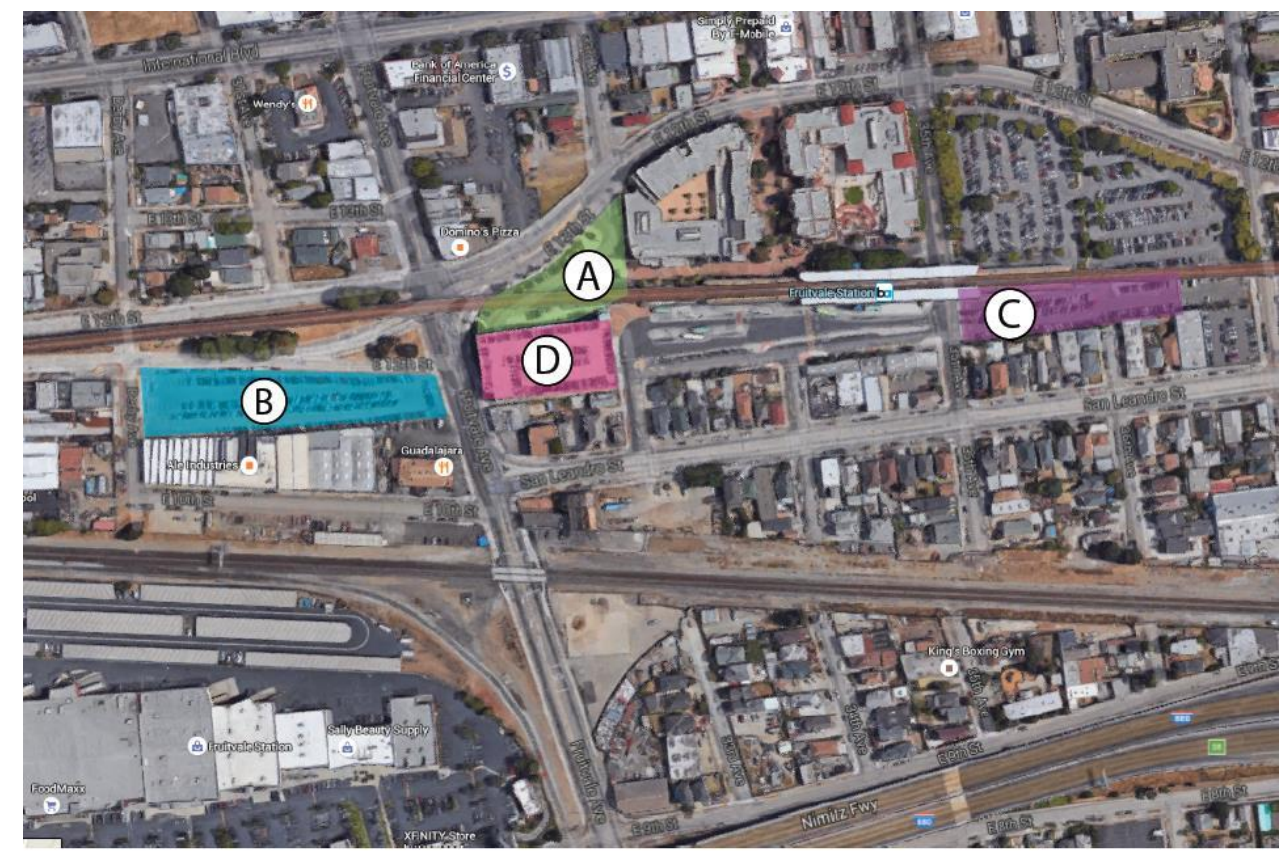

BART Parking Locations
(A) Lot adjacent to BART garage
(B) Lot west of Fruitvale Avenue
(C) Lot south of BART tracks
(D) BART garage

Figure 4.3. BART-Owned Parking Facilities 
Land use regulations were also a challenge. The City of Oakland had to amend its zoning code to allow for the density planned at Fruitvale Village. An overlay zone was created which permitted higher densities around transit stations, offered density bonuses, and reduced prescribed parking minimums. Such a land use policy would be progressive even in today's planning environment, but in the 1990s, it was way ahead of its time.

\section{Transit Connection}

Fruitvale Transit Village is served by BART's Blue, Orange, and Green lines, with very frequent service and high accessibility to much of the Bay Area (Figure 4.4). Service extends late into the evening, and six-minute headways are common for most hours of the day. Fruitvale Station also acts as a hub for AC Transit. AC Transit is an Oakland-based bus service provider, with service mostly in Alameda and Contra Costa counties. The Fruitvale AC Transit hub is served by 14 AC Transit bus lines, with late/early and frequent service. This extensive provision of bus service greatly contributes to the overall accessibility of the Fruitvale Station. Additionally, bike parking and storage lockers make connecting to transit via active transportation modes more convenient. A bike garage is housed in the northeast building of the transit village. It was initially supported and is administered and maintained by a partnership among BART, The Unity Council, the City of Oakland, and Alameda Bicycle.

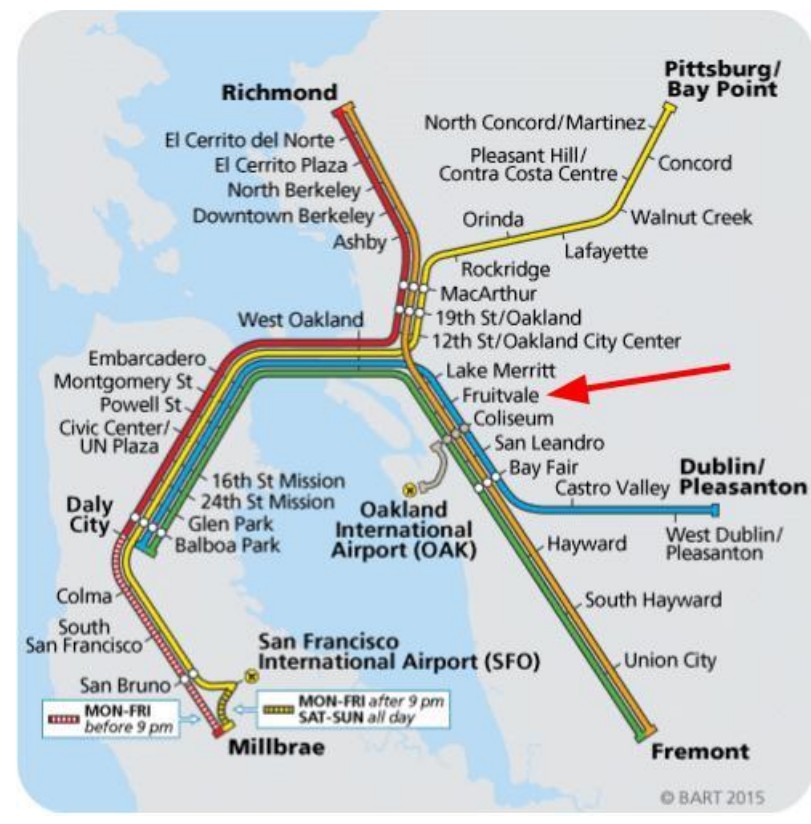

(a) BART rail system map

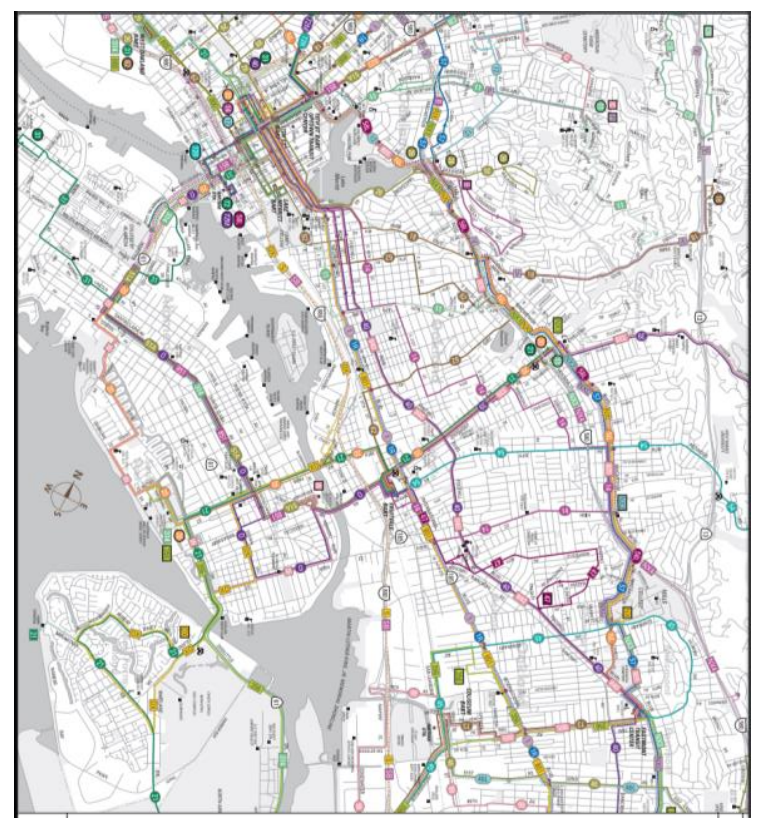

(b) AC Transit Oakland bus system map

\section{Figure 4.4. Transit Services at Fruitvale Village}

\section{The Development Itself}

The Fruitvale Transit Village currently consists of two buildings, one in the northwest portion of the site, the other in the southeast. The buildings are separated by a pedestrian plaza and ringed by streets, sidewalks, and the rail line itself (Figure 4.5). The first phase of development broke ground in 1999 and finished in 2004. This first phase constitutes the study area for this case study. At the time of data collection in late 2015, Phase II had not yet begun. 
The first phase consists of 47 residential units, 101,000 square feet of office space, and 40,000 square feet of retail space. The northwest building, also referred to by its east coordinates, $3301 \mathrm{E}$. 12th Street, is the home to the Cesar Chavez Library, the Fruitvale Senior Center, a large bicycle garage, and about half the development's residential units. The southeast building, 3411 E. 12 Street, houses The Unity Council, a Head Start Center, La Clinica de la Raza, and the remainder of the residential units. The majority of residential units are market rate, with 10 out of 47 considered affordable.

Table 4.1 Development Summary of Fruitvale Village TOD Project

\begin{tabular}{|l|l|l|l|}
\hline Land uses & Description & Unit & Occupancy \\
\hline Residential & Third floor & $\begin{array}{l}47 \text { units (34 one-bedroom units } \\
\text { including 4 affordable units and } \\
13 \text { two-bedroom units including 6 } \\
\text { affordable units) }\end{array}$ & $100 \%$ \\
\hline Office & Second floor & 39,104 sq. ft. & $100 \%$ \\
\hline $\begin{array}{l}\text { Other commercial } \\
\text { uses }\end{array}$ & Ground floor & Unit & $100 \%$ \\
\hline Parking & Description & Occupancy* \\
\hline $\begin{array}{l}\text { BART Park-and- } \\
\text { Ride garage }\end{array}$ & 5-level parking structure & 516 stalls & $100 \%$ \\
\hline $\begin{array}{l}\text { BART Park-and- } \\
\text { Ride Lot A }\end{array}$ & $\begin{array}{l}\text { BART-owned garage- } \\
\text { adjacent lot (permit only) }\end{array}$ & 51 stalls & $100 \%$ \\
\hline $\begin{array}{l}\text { BART Park-and- } \\
\text { Ride Lot B }\end{array}$ & $\begin{array}{l}\text { BART-owned lot west of } \\
\text { Fruitvale Ave }\end{array}$ & 216 stalls & $99.5 \%$ \\
\hline $\begin{array}{l}\text { BART Park-and- } \\
\text { Ride Lot C }\end{array}$ & $\begin{array}{l}\text { BART-owned lot south of } \\
\text { tracks, between 35th Ave } \\
\text { and 37th Ave (fee only) }\end{array}$ & 79 stalls & $100 \%$ \\
\hline $\begin{array}{l}\text { Fruitvale Village } \\
\text { Building \#1 (3301 } \\
\text { East 12th Street) } \\
\text { Garage }\end{array}$ & $\begin{array}{l}\text { Parking garage with } \\
\text { shared parking }\end{array}$ & $\begin{array}{l}84 \text { stalls (4 accessible stalls and 4 } \\
\text { stalls for CitiBank) } \\
1 \text { parking space per unit } \\
\text { (incorporated into rent) } \\
\text { Additional residential parking for } \\
\text { \$90 per month per stall }\end{array}$ & $89.3 \%$ \\
\hline $\begin{array}{l}\text { Fruitvale Village } \\
\text { Building \#2 (3411 } \\
\text { East 12th Street) } \\
\text { Garage }\end{array}$ & $\begin{array}{l}\text { Parking garage with } \\
\text { shared parking }\end{array}$ & $\begin{array}{l}\text { 72 stalls (4 accessible stalls and } \\
10 \text { stalls for La Clínica) } \\
\text { (incorporated into rent) } \\
\text { Additional residential parking for } \\
\text { \$90 per month per stall }\end{array}$ & $77.8 \%$ \\
\hline
\end{tabular}

* The peak occupancy on November 5, 2015.

Table 4.2. Commercial Uses in Fruitvale Village TOD

\begin{tabular}{|c|c|c|c|}
\hline Land uses & Lessee & Unit (sq.ft.) & \\
\hline \multirow{7}{*}{ Office } & La Clínica de la Raza & 20,555 & \multirow{7}{*}{100,830} \\
\hline & Cesar Chavez Library & 15,120 & \\
\hline & Westcoast Children's Clinic & 9,698 & \\
\hline & De Colores Head Start & 16,517 & \\
\hline & SEIU-USWW Union Office & 13,390 & \\
\hline & Fruitvale-San Antonio Senior Center & 8,548 & \\
\hline & ARISE High School (260 students) & 17,002 & \\
\hline
\end{tabular}




\begin{tabular}{|l|l|r|}
\hline \multirow{5}{*}{} & ARISE High Annex & 3,744 \\
\cline { 2 - 3 } & Bay Dental & 2,034 \\
\cline { 2 - 3 } & Elegant Smiles & 1,309 \\
\cline { 2 - 3 } & Peralta Service Corporation & 1,289 \\
\cline { 2 - 3 } Other & Subway & 1,319 \\
\cline { 2 - 3 } & Property Management Office & 977 \\
\cline { 2 - 3 } & Citibank & 3,031 \\
\cline { 2 - 3 } & CS Edge & 1,547 \\
\cline { 2 - 3 } & Metro PCS & 944 \\
\cline { 2 - 3 } & Fruitvale Optometry & 911 \\
\cline { 2 - 3 } & State Farm Insurance & 889 \\
\cline { 2 - 3 } & Papa John's Pizza & 989 \\
\cline { 2 - 3 } & Emil's Burger & 1,147 \\
\cline { 2 - 3 } & WCCC Admin & 1,477 \\
\cline { 2 - 3 } & Market One & 1,578 \\
\cline { 2 - 3 } & Lee's Garden Restaurant & 2,063 \\
\cline { 2 - 3 } & PowderFace Beignets \& Coffee & 1,369 \\
\cline { 2 - 3 } & Ibrow & 892 \\
\cline { 2 - 3 } & Community Check Cashing & 1,362 \\
\cline { 2 - 3 } & Mira Law & 1,697 \\
\cline { 2 - 3 } & WCCC Accounting & 1,599 \\
\cline { 2 - 3 } & AN's Jewelry & 1,361 \\
\cline { 2 - 3 } & Obelisco's Mexican Restaurant & 2,621 \\
\cline { 2 - 3 } & ARISE High Art studio & 1,237 \\
\cline { 2 - 3 } & WCCC Annex & 1,718 \\
\hline
\end{tabular}

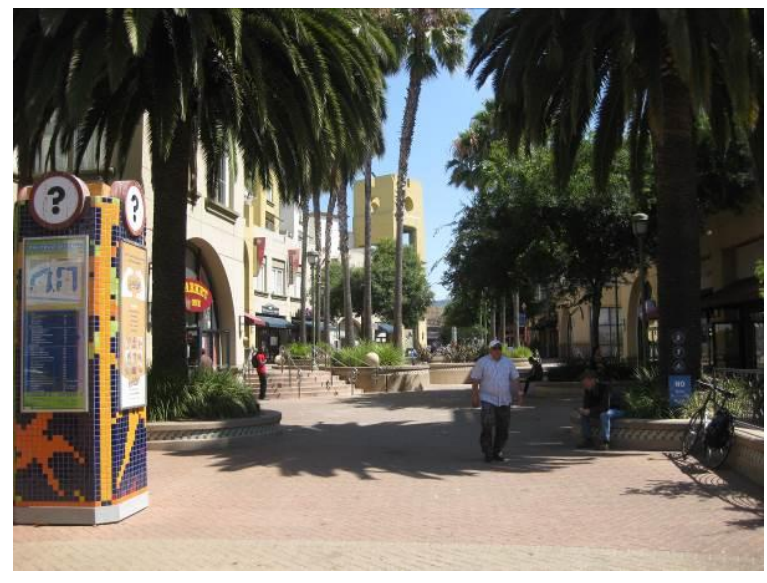

(a) Fruitvale's pedestrian plaza

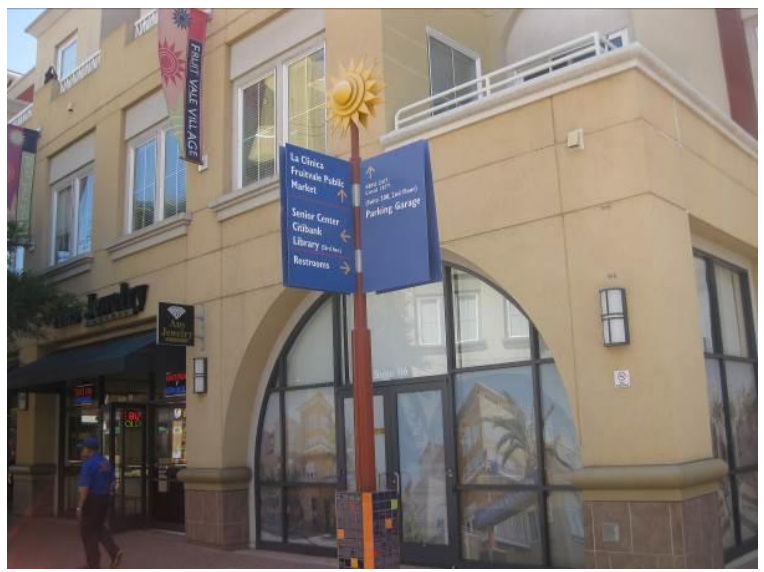

(b) Apartments above shops 


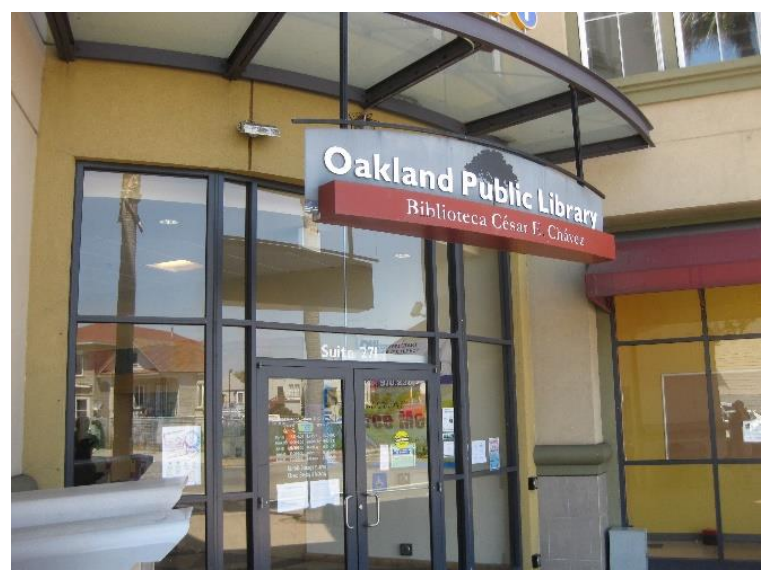

(c) One of six major "office" uses

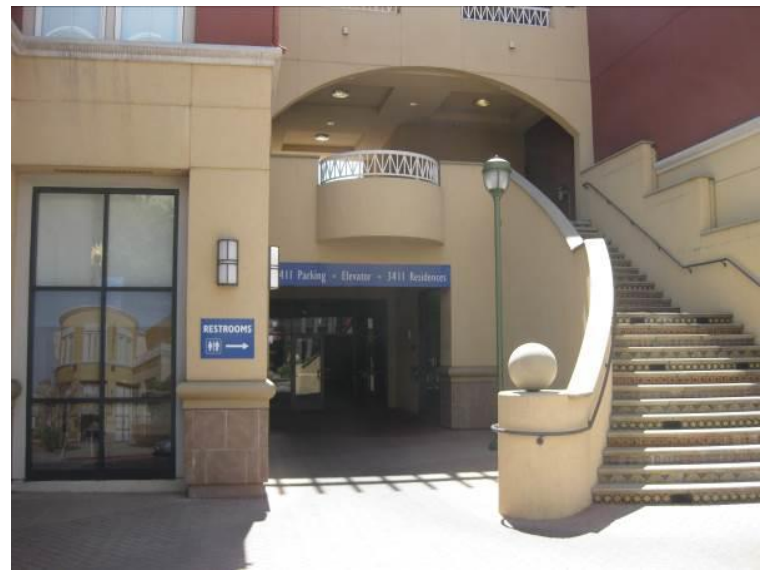

(e) Residential entrance to building 3411

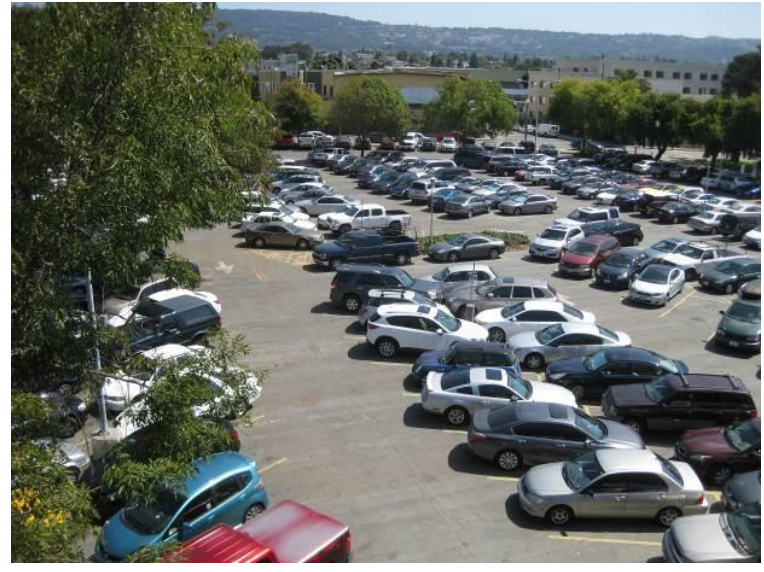

(g) Parking lot under redevelopment

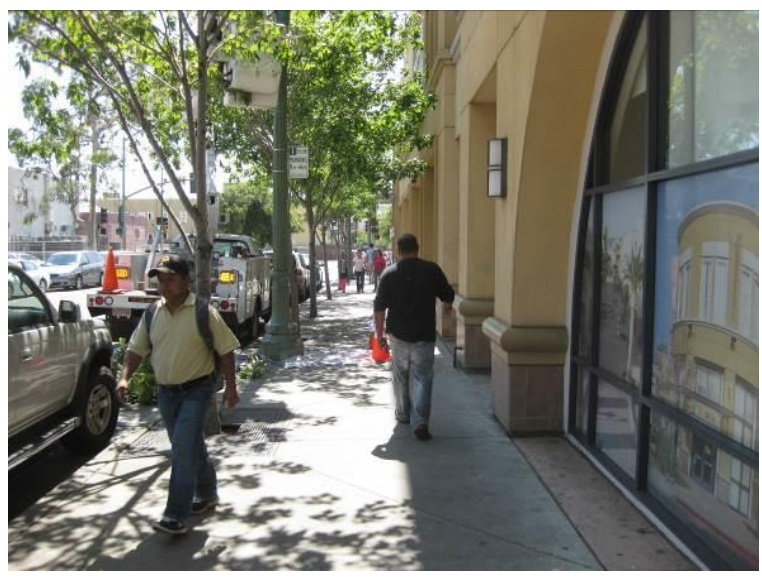

(d) Street frontage on E. $12^{\text {th }}$ Street

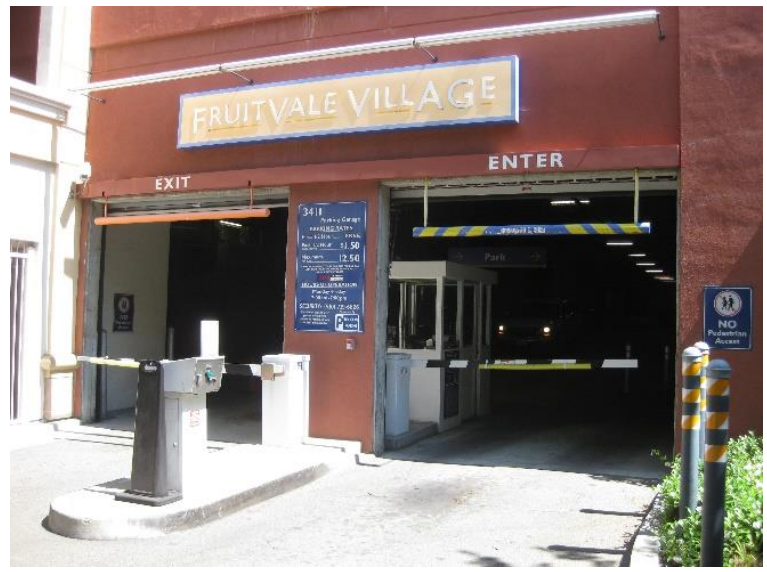

(f) Shared parking garage entrance for 3411

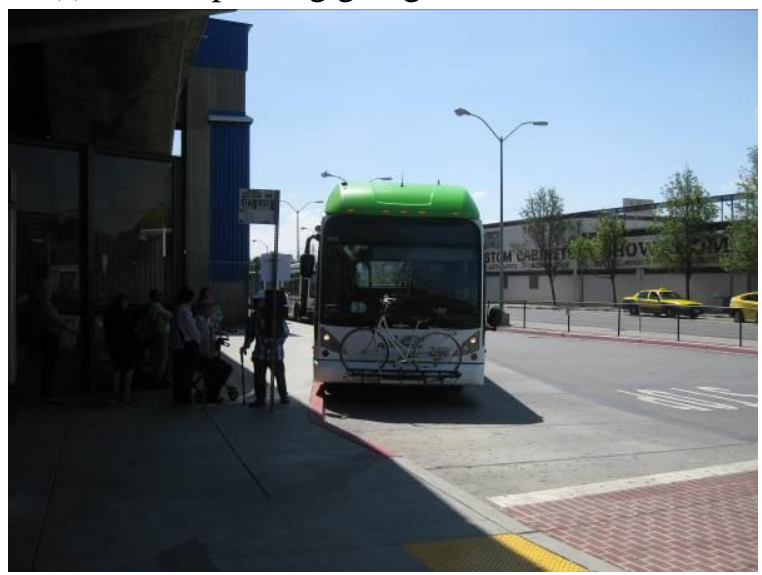

(h) AC Transit Bus-BART interface 


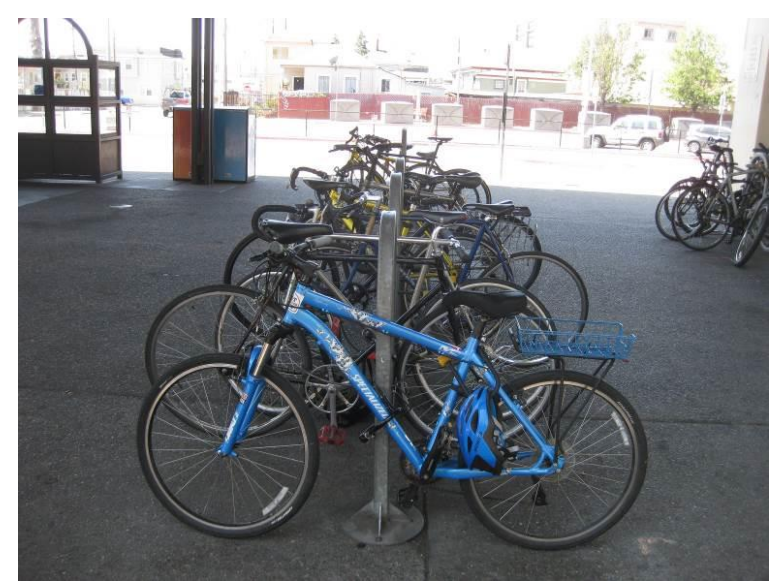

(i) Covered bike parking at BART station

Figure 4.5. Fruitvale Village TOD

\section{Phase II}

Phase II of the Fruitvale Transit Village project, although not a part of this study as it has not yet been constructed, is noteworthy because it will change both the makeup of the development and, possibly, the character of the community. For Phase II, The Unity Council has filed plans with the city to move forward with 94 mixed-income units that will rise on the surface parking lot southeast of the existing Phase I Fruitvale Village buildings. The entire second phase of the project will ultimately include 275 units, most of which will be market rate. Unlike the existing part of Fruitvale Village, no commercial space is proposed for the second phase.

Parking is an interesting component of Phase II. Where certain other case studies presented in this report have provided more than one space per residential unit, the original proposal for Phase II only included one space per unit. Even more surprisingly, this figure has since been cut in half. This is a drastic reduction in parking supply, and far below not only ITE suggested levels, but even more daring than the most progressive projects visited in this report that gamble on unprecedentedly low parking allotments.

Such a proposal demonstrates progress on two fronts. First, the FDC is showing confidence in recent observations, for which this report hopes to provide empirical support, that standard parking requirements are excessive for well-designed TODs. Second, it shows that municipalities are displaying faith in this notion. A developer with a wild idea of providing such a reduction in parking supply would not be able to test her wild idea if not for the support of the municipality and its respective zoning ordinance.

\section{Data Collection}

The multimodal transportation planning firm Nelson/Nygaard developed a data collection plan and protocols, and managed data collection in the field and subsequent data entry for three types of travel data: (1) a full count of all persons entering and exiting the Fruitvale Transit Village, (2) a brief intercept survey of a sample of individuals entering and exiting the building, and (3) parking inventory and occupancy surveys of all off-street parking accessory to the commercial and residential uses of the Fruitvale Transit Village, and the adjacent off-street parking facilities owned and operated by Bay Area Rapid Transit (BART) for all day use by transit riders. 
The intent of this approach was to develop an accurate measure of total trip generation associated with the commercial and residential uses at the site, as well as complementary travel survey and parking utilization data that provide a picture of the mode of travel, origin/destination, parking location - if applicable - and purpose for all trips to and from the building throughout the course of the day.

All survey and trip count data were recorded on location at the Fruitvale Transit Village between 7:30 a.m. and 8:00 p.m. on Thursday, November 5, 2015. Parking utilization was surveyed at each facility approximately every two hours during this period. In addition, an "overnight" count of parking occupancy was conducted at both Fruitvale Transit Village garages and BART park-and-ride garage and lots between 12:00 a.m. and 1:00 a.m. on early Friday morning to determine parking occupancy during the anticipated period of peak utilization associated with the predominant residential use.

For the purpose of counting person trips generated and recording travel patterns, separate teams of surveyors were employed to (a) count people entering/exiting at each building entrance, and (b) conduct intercept surveys of individuals entering, exiting, and passing through the development (Figure 4.6). Intercept surveys were conducted by temporary agency employees as well as planning students from schools around the Bay Area. All parking inventory and occupancy counts were conducted by NelsonlNygaard planning staff, who also supervised survey workers at building entrances.

Throughout the survey period, 13 to 14 people were employed to conduct trip counts. ${ }^{5}$ These surveyors were stationed on public sidewalks in fixed positions where they could easily and continuously observe primary entrances to the building. Counters - stationed on the sidewalk surrounding the building and throughout the pedestrian plaza between the development's two buildings - tallied the number of people entering and exiting each door by hour. Counters stationed at the southern side of the two buildings recorded people entering/exiting the Fruitvale Transit Village parking facility by motor vehicle, bicycle, or another mode - noting vehicle occupancy when visible.

A separate team of surveyors - four all day- were employed to intercept and survey people entering and exiting the building. These surveyors were initially stationed along Avenida de la Fuente, the pedestrian plaza between the two Fruitvale Transit Village buildings, where the vast majority of pedestrian traffic is concentrated. Surveyors were eventually instructed to leave their stations as necessary to intercept and attempt to survey individuals seen moving toward an entrance or away from a building exit.

As a first step, the surveyor recorded the time of intercept by checking a box on the data collection form associated with one of four 15-minute periods per hour. Next, the surveyor noted whether the subject was "arriving" at or "leaving" the building, and the type of entrance/exit used.

People leaving the building were asked: (1) "How do you plan to get to your next destination?" (e.g., by driving alone, walking, taking BART, etc.), and (2) What is the purpose of your trip? (e.g., "Going home," "Going to work," "Shopping," etc.).

\footnotetext{
${ }^{5}$ Although there were 16 counter locations initially identified, several counters did not show up on the day of the survey and trip count, requiring two counters to cover four locations in the morning and one counter to cover two locations in the afternoon.
} 
People arriving at the building were asked: (1) "How did you get here?” (e.g., by driving alone, walking, taking BART, etc.), and (2) What is the purpose of your trip? (e.g., "I live here/coming home," "coming to work," "shopping," etc.).

Individuals who indicated that they had arrived by, or would be leaving by, automobile were also asked where they had parked their vehicle (e.g., "on-street," in the "[Fruitvale Transit Village] garage," in a "BART lot/garage," or at an "other" location/facility).

Surveyors were instructed to count and attempt to intercept only individuals observed walking to or from an entrance to the Fruitvale Transit Village (or, when observing the garage entrance, only drivers and passengers in vehicles entering/exiting the garage driveway to/from the public street). Individuals merely walking past the development or walking between the BART station and other trip origins/destinations, including the BART garage, were not counted or surveyed unless these instructions were disregarded by the counter or surveyor.

The estimated total person trip count, and hence the total vehicle count, is overestimated by an unknown amount. This is because travelers may have been counted entering or exiting the garage then again on the sidewalk or in the plaza. The mode shares are likely accurate because travelers would not have agreed to participate in the intercept survey more than once. But the same person could have been counted more than once. With so many retail, office, school, and social service uses, there is also the likelihood that people were over-counted walking from one use to another. In particular, Arise High School, located on the second floor of the Fruitvale Transit Village development, had many students coming and going to various shops within the development between classes. Our counts (and intercept surveys) did not distinguish internal trips from external trips. That is to say, there is doubtless some internal capture in the project with this much commercial activity, but there was no way to judge the magnitude from our counts. 
To the extent that travelers were over-counted, there is a conservative bias to our results.

\section{Fruitvale Village Counter Locations}

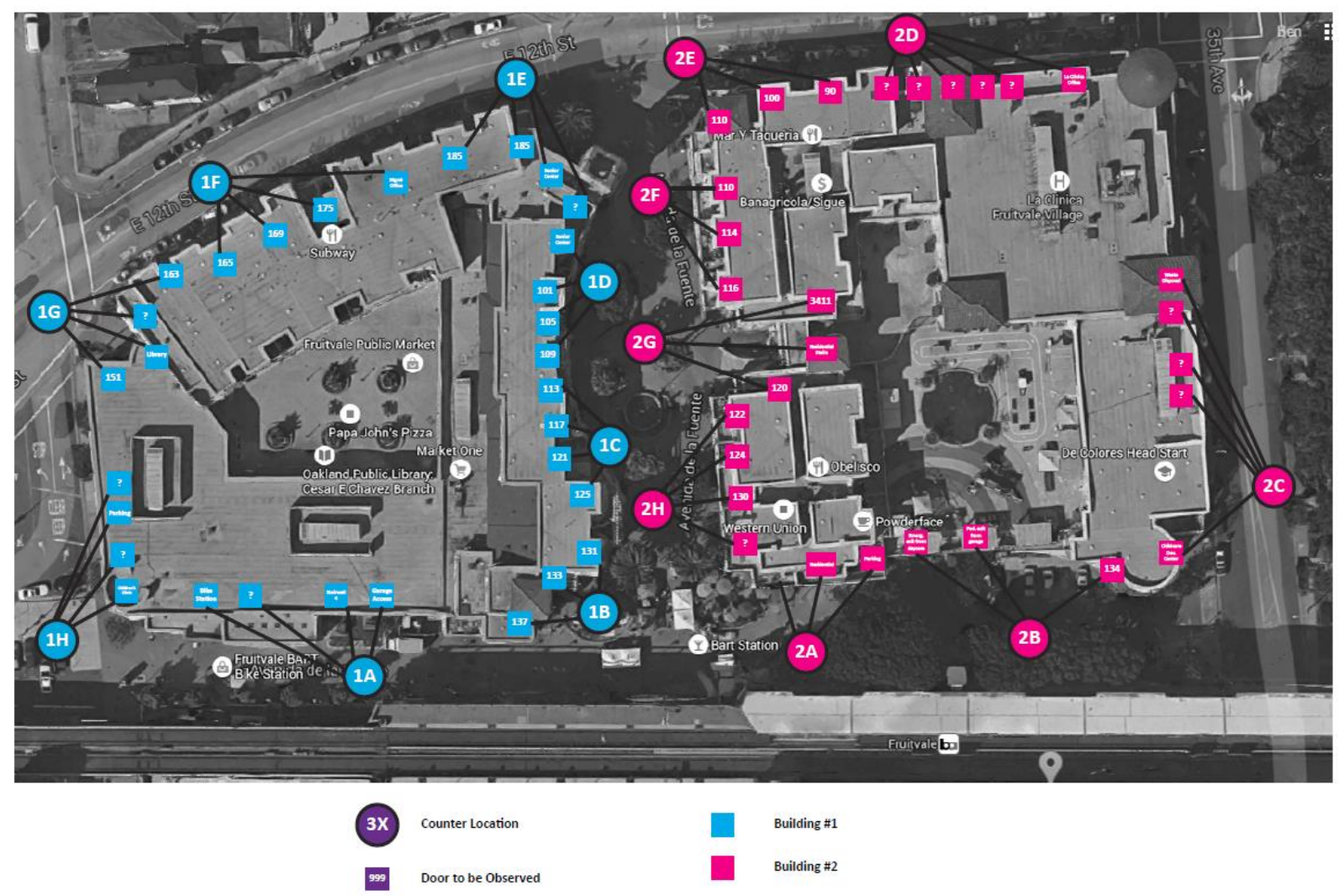

Figure 4.6. Surveyor Location Map

\section{Mode Shares}

In the intercept survey, we had one surveyor at each entrance to the development to ask people questions. We received 1,036 valid surveys from 1,243 respondents. One question in the survey was what transportation mode was used to get to this development. The mode share from the intercept survey is presented in Table 4.3. We applied this mode share to the total trip-generation counts by entrance to compute the final weighted mode shares.

The final mode shares for Fruitvale Village TOD are 28 percent walk, 4 percent bike, 15 percent bus, 26 percent rail, and 23 percent auto (Table 4.3). According to 2009 National Household Travel Survey, the San Francisco-Oakland-San Jose region mode shares are 13.6 percent walk, 1.5 percent bike, 1.8 percent bus, 0.6 percent rail, and 81.6 percent auto. Compared with the region mode shares, Fruitvale Village TOD shows a significant mode shift from auto to walk, bike, and transit. Fruitvale Village TOD exhibits approximately double the share of walk trips as the regional average, 2.6 times the share of bike trips, 8.3 times the percentage of bus trips, and 43 times the percentage of rail trips.

Table 4.3. Mode Shares in Fruitvale Village TOD 


\begin{tabular}{|l|r|r|r|r|r|r|r|}
\hline \multicolumn{1}{|c|}{ Entrance } & \multirow{2}{*}{ Count } & \multicolumn{7}{c|}{ Modercept survey } \\
\cline { 3 - 9 } & & Walk & Bike & \multicolumn{1}{c|}{ Bus } & Rail & Auto & Other \\
\hline Parking Garage & 12 & $0.00 \%$ & $0.00 \%$ & $0.00 \%$ & $16.67 \%$ & $83.33 \%$ & $0.00 \%$ \\
\hline Residential Sidewalk & 604 & $24.50 \%$ & $4.80 \%$ & $14.24 \%$ & $31.79 \%$ & $20.86 \%$ & $3.81 \%$ \\
\hline Residential Plaza & 420 & $35.95 \%$ & $3.81 \%$ & $17.62 \%$ & $18.57 \%$ & $21.67 \%$ & $2.38 \%$ \\
\hline \multicolumn{7}{|c|}{ Trip generation counts } \\
\hline \multirow{2}{*}{ Entrance } & \multirow{2}{*}{ Count } & \multicolumn{7}{|c|}{ Count for modes } \\
\cline { 3 - 9 } & & Walk & Bike & Bus & Rail & Auto & Other \\
\hline Parking Garage & 492 & 0 & 0 & 0 & 82 & 410 & 0 \\
\hline Residential Sidewalk & 9,534 & 2,336 & 458 & 1357 & 3031 & 1989 & 363 \\
\hline Residential Plaza & 6,532 & 2,348 & 249 & 1151 & 1213 & 1415 & 156 \\
\hline Final mode share & 16,558 & $28.29 \%$ & $4.27 \%$ & $15.15 \%$ & $26.12 \%$ & $23.04 \%$ & $3.13 \%$ \\
\hline
\end{tabular}

\section{Trip Generation}

Our actual trip generation counts from the survey did not distinguish residential trips and commercial trips. To compare the actual trip generation with ITE's benchmarks, we combine all estimated trips for different uses into a total that can be compared to ITE.

There were 16,558 person trips and 3,056 vehicle trips observed for the whole day of the survey. Those trips were generated by 47 occupied residential units and 139,934 square feet of leased commercial space.

We used the ITE Trip Generation Manual's value for "221 Low-Rise Apartment," which is defined as "apartments (rental dwelling units) are units located in rental buildings that have one or two levels (floors)," to calculate the trip-generation rate of the residential building at Fruitvale Village TOD. The average daily vehicle trip-generation rate is 6.59 per dwelling units on a weekday.

For the trip-generation rate of the office uses at the Fruitvale Village TOD, we used " 492 Health/Fitness Club" for the senior center (Fruitvale-San Antonio Senior Center), "530 High School" for the school (ARISE High School), "565 Day Care Center" for the early childhood development services (De Colores Head Start), "590 Library" for the library (Cesar Chavez Library), "630 Clinic" for the two clinics (La Clínica de la Raza and Westcoast Children's Clinic), and "714 Corporate Headquarters Building" for the labor union (SEIU-USWW Union Office). We considered all other commercial uses a shopping center and used "826 Specialty Retail Center" for its trip-generation rate. Many smaller lessees occupy very little space and lack appropriate ITE land use categories, so we treated Fruitvale's other commercial uses (called "retail" by the property manager) as a specialty retail center to calculate ITE trip-generation rates. The ratio of retail space to residential units is much greater for Fruitvale than other TODs studied.

Fruitvale Village TOD would be expected to generate 5,899 daily vehicle trips based on the ITE's tripgeneration rates (Table 4.4). Actual vehicle trips observed on the survey day were 3,056, which is 51.8 percent of the ITE's expected value.

Table 4.4. The Comparison of Daily Vehicle Trip Generation between ITE Guideline and Fruitvale Village TOD

\begin{tabular}{|l|l|l|r|}
\hline & Trip generation rate & Total units & Total daily trips \\
\hline ITE guideline & - & - & 5,899 \\
\hline
\end{tabular}




\begin{tabular}{|l|l|r|r|}
\hline 221 Low-Rise Apartment & 6.59 & 47 & 310 \\
\hline 492 Health/Fitness Club & 32.93 & 8,548 & 281 \\
\hline 530 High School & $1.71^{*}$ & $260^{*}$ & 444 \\
\hline 565 Day Care Center & 74.06 & 16,517 & 1,223 \\
\hline 590 Library & 56.24 & 15,120 & 850 \\
\hline 630 Clinic & 31.45 & 30,253 & 951 \\
\hline 714 Corporate Headquarters Building & 7.98 & 13,390 & 107 \\
\hline 826 Specialty Retail Center & 44.32 & 39,104 & 1,733 \\
\hline Fruitvale Village TOD & - & - & $3,056^{* *}$ \\
\hline
\end{tabular}

*This is the trip-generation rate per student; there are 260 students in the school.

**The total vehicle trips were estimated by multiplying the share of person trips by drive alone, HOV driver, and car share from the intercept survey by the total number of person trips from the 100 percent count on the survey day.

\section{Parking Generation}

Parking supply and demand recorded for the Fruitvale Village TOD project were compared to the number of parking stalls and occupancy rates from the 2010 ITE Parking Generation manual.

\section{Residential}

The ITE Parking Generation Manual defines "221 Low/Mid-Rise Apartment" as rental dwelling units located in rental buildings up to four stories (floors) in height. This is the best match for the one-story multifamily residential uses on a three-story building at the Fruitvale Village TOD. The average parkingsupply ratio reported by ITE is 1.4 parking spaces per dwelling unit at both urban and suburban sites (derived from 68 study sites).

For the ITE land use category 221: Low/Mid-Rise Apartment (urban location), the average peak period parking demand from 40 study sites is 1.20 vehicles per dwelling unit with a standard deviation of 0.42 , a range of $0.66-2.50$, an $85^{\text {th }}$ percentile value of 1.61 , and a $33^{\text {rd }}$ percentile value of 0.93 . Besides the average rate, the ITE manual also provides the best-fitting regression line for estimating total parked vehicles as a function of the total number of dwelling units:

$$
\mathrm{P}=0.92 \mathrm{x}+4
$$

Where $\mathrm{P}=$ parked vehicles and $\mathrm{x}=$ dwelling units

Fruitvale Village has two parking garages for the development. Both are shared by residential and commercial users. While all 47 dwelling units (23 units in Building A and 24 units in Building B) receive the right to use a single space per dwelling unit as part of their monthly rent, spaces in the garages are not reserved for residential or commercial users. Therefore, parking supply is impossible to quantify. The actual number of parking stalls available to residents is somewhere between 1.0 per unit and the total number of stalls in the garages. Some residents may not even have an automobile and hence may not use any stalls. Further complicating matters, residents have the option of paying $\$ 90$ a month to park a second vehicle.

Based on the number of parking spaces occupied from midnight-1 am, which presumably includes only residential parkers (no commercial parkers at that hour), we estimate that the 23 units in Building A (east 
building) occupy 25 parking spaces, and the 24 units in Building B (west building) occupy 23 spaces. This means that two rental units from Building A are paying for extra spaces beyond the one space per unit that comes with the rent. The peak occupancy of parking spaces in the garages occurs in the morning (midnight-1:00 a.m.). Thus, the peak residential parking demand relative to supply is 25/23, or 1.09, for Building A and 23/24, or 0.96, for Building B. The actual demand (48 spaces) is a little bit less than the ITE average of 56 (1.20 spaces per unit $* 47$ occupied units) and almost the same with the ITE regression estimate of $47(0.92 * 47+4)$. The actual residential peak period parking demand at Fruitvale Village TOD is 86 percent $(100 * 48 / 56)$ of ITE's average demand.

\section{Mixed Use}

There is a total of 139,934 square feet of leasable space for commercial uses at the Fruitvale Village TOD, all of which was leased at the time of this study. There are 47 apartments total, all of which were occupied at the time of this study. There are two parking garages that are available to commercial and residential users. We do not have separate parking supply and demand data for each use, so we treat them as a whole. There is a total of 156 parking spaces in the two garages.

Table 4.5 lists residential and commercial uses parking in the garages and peak parking demands for the closest analog in the ITE Parking Generation manual. All the land uses in Fruitvale Village were similarly matched to land uses in the ITE Parking Generation manual. These uses are "221 Low/Mid-Rise Apartment”, “492 Health/Fitness Club”, "530 High School”, "565 Day Care Center”, "590 Library”, “630 Clinic", and "701Office Building" (the closest analogue to the labor union: SEIU-USWW Union Office). We considered all other commercial uses shopping center and used "820 Shopping Center" to calculate a parking-generation rate. See details in Table 4.5.

Parking supply for these mixed uses is 690 spaces, according to the ITE manual $(1.4 * 47+5.7 * 8.548+0.1 * 260+3.5 * 16.517+3.5 * 15.12+6.4 *(20.555+9.698)+4 * 13.39+4.9 * 39.104)$. The actual parking supply at Fruitvale Village TOD is 156 spaces for all residential and commercial uses, only about 23 percent of the ITE guideline (see Table 4.5).

Average total peak period parking demand for all residential and commercial uses is 493 spaces, according to ITE's guidelines $(1.2 * 47+5.27 * 8.548+0.09 * 260+3.16 * 16.517+2.61 * 15.12+4.94 *(20.555$ $+9.698)+2.47 * 13.39+2.55 * 39.104)$. The actual peak period parking demand of the commercial uses and residential at Fruitvale Village TOD was 131 occupied spaces on the survey day, just 27 percent of the ITE estimate.

Table 4.5. Comparison of Parking Supply and Demand Between Fruitvale Village TOD and ITE Guidelines

\begin{tabular}{|l|r|r|r|r|}
\hline \multicolumn{4}{|c|}{ Residential } \\
\hline & \multicolumn{2}{|c|}{ Supply } & \multicolumn{2}{c|}{ Peak period demand } \\
\cline { 2 - 5 } & $\begin{array}{l}\text { Parking spaces per } \\
\text { unit }\end{array}$ & $\begin{array}{l}\text { Total parking } \\
\text { spaces }\end{array}$ & Vehicles per unit & $\begin{array}{l}\text { Total parked } \\
\text { vehicles }\end{array}$ \\
\hline $\begin{array}{l}\text { ITE guideline: 221 } \\
\text { Low/Mid-Rise Apartment }\end{array}$ & 1.4 & 66 & 1.20 & 52 \\
\hline $\begin{array}{l}\text { Fruitvale Village TOD } \\
\text { (Building A) }\end{array}$ & NA $^{\mathrm{a}}$ & $\mathrm{NA}^{\mathrm{a}}$ & 1.09 & 25 \\
\hline
\end{tabular}




\begin{tabular}{|c|c|c|c|c|}
\hline $\begin{array}{l}\text { Fruitvale Village TOD } \\
\text { (Building B) }\end{array}$ & $\mathrm{NA}^{\mathrm{a}}$ & $\mathrm{NA}^{\mathrm{a}}$ & 0.96 & 23 \\
\hline \multicolumn{5}{|c|}{ Mixed use (occupied space only) } \\
\hline & \multicolumn{2}{|c|}{ Supply } & \multicolumn{2}{|c|}{ Peak period demand } \\
\hline & $\begin{array}{l}\text { Parking spaces per } \\
1,000 \text { sq.ft. GFA }\end{array}$ & $\begin{array}{l}\text { Total parking } \\
\text { spaces }\end{array}$ & $\begin{array}{l}\text { Vehicles per } \\
1,000 \text { sq. ft. GFA }\end{array}$ & $\begin{array}{l}\text { Total parked } \\
\text { vehicles }\end{array}$ \\
\hline ITE guideline & - & 690 & - & 493 \\
\hline $\begin{array}{l}221 \text { Low/Mid-Rise } \\
\text { Apartment }\end{array}$ & 1.4 & 66 & 1.20 & 56 \\
\hline 492 Health/Fitness Club & 5.7 & 49 & 5.27 & 45 \\
\hline 530 High School & $0.1^{\mathrm{b}}$ & 26 & $0.09^{\mathrm{b}}$ & 19 \\
\hline 565 Day Care Center & 3.5 & 58 & 3.16 & 52 \\
\hline 590 Library & 3.5 & 53 & 2.61 & 39 \\
\hline 630 Clinic & 6.4 & 194 & 4.94 & 149 \\
\hline 701Office Building & 4.0 & 54 & 2.47 & 33 \\
\hline 820 Shopping Center & $4.9^{\mathrm{c}}$ & 192 & 2.55 & 100 \\
\hline Fruitvale Village TOD & - & 156 & - & 131 \\
\hline \multicolumn{5}{|c|}{ Total } \\
\hline & \multicolumn{2}{|l|}{ Supply } & \multicolumn{2}{|c|}{ Peak period demand } \\
\hline ITE guideline & & 690 & & $\mathrm{NA}^{\mathrm{d}}$ \\
\hline Fruitvale Village TOD & & 156 & & $131^{\mathrm{e}}$ \\
\hline
\end{tabular}

${ }^{a}$ Residents are permitted to park one vehicle per unit with their lease agreements. They can park additional vehicles at $\$ 90$ monthly per vehicle. However, there are no reserved spaces for residents and only a handful of reserved spaces for certain commercial uses. The rest of the parking is shared.

${ }^{\mathrm{b}}$ Per student.

${ }^{\mathrm{c}}$ Parking supply ratio for community shopping center.

${ }^{\mathrm{d}}$ The peak parking demand of residential and the peak parking demand of commercial are different periods during a day. We cannot simply sum them to get a total peak parking demand.

${ }^{\mathrm{e}}$ The most overall parked vehicles at the TOD at one hour of the survey day.

In sum, the overall parking supply for the residential and occupied commercial space at Fruitvale Village TOD is be 690 spaces, according to the ITE guideline. But the actual parking supply for all residential and occupied commercial space is 156 spaces, only 23 percent of the ITE guideline. Actual peak parking demand for all uses at Fruitvale Village TOD was 131 occupied spaces for the one hour on the survey day with the most cars. This is only 19 percent of the ITE supply guideline and 84 percent of the Fruitvale Village TOD's actual supply.

\section{Parking Demands for Different Land Uses}

At Fruitvale Village TOD, the BART park-and-ride parking structure and lots are independent. However, it is not possible to distinguish residential from commercial uses in the parking garages for the development, so we consider them as a whole. Parking demand for BART users and the developments during the survey day are shown in Figure 4.7.

For the BART park-and-ride, demand was high at midday. Almost 100 percent of the parking spaces were occupied from 11:00 a.m. to 2:00 p.m. Demand dropped quickly after that, reaching a low of 5 percent occupancy at midnight. 
Parking demand at the TOD garage was also high at midday. More than 80 percent of the parking spaces were occupied from 11:00 a.m. to 2:00 p.m. Demand dropped to around 30 percent occupancy after 8:00 p.m., when most of parked vehicles likely represent residential demand.

Parking demand at both the BART park-and-ride and the Fruitvale Village TOD garages were high during daytime. Overall parking occupancy rates at Fruitvale Village TOD are higher than at Redmond TOD. This finding clearly shows the benefit of sharing parking among different users at TODs.

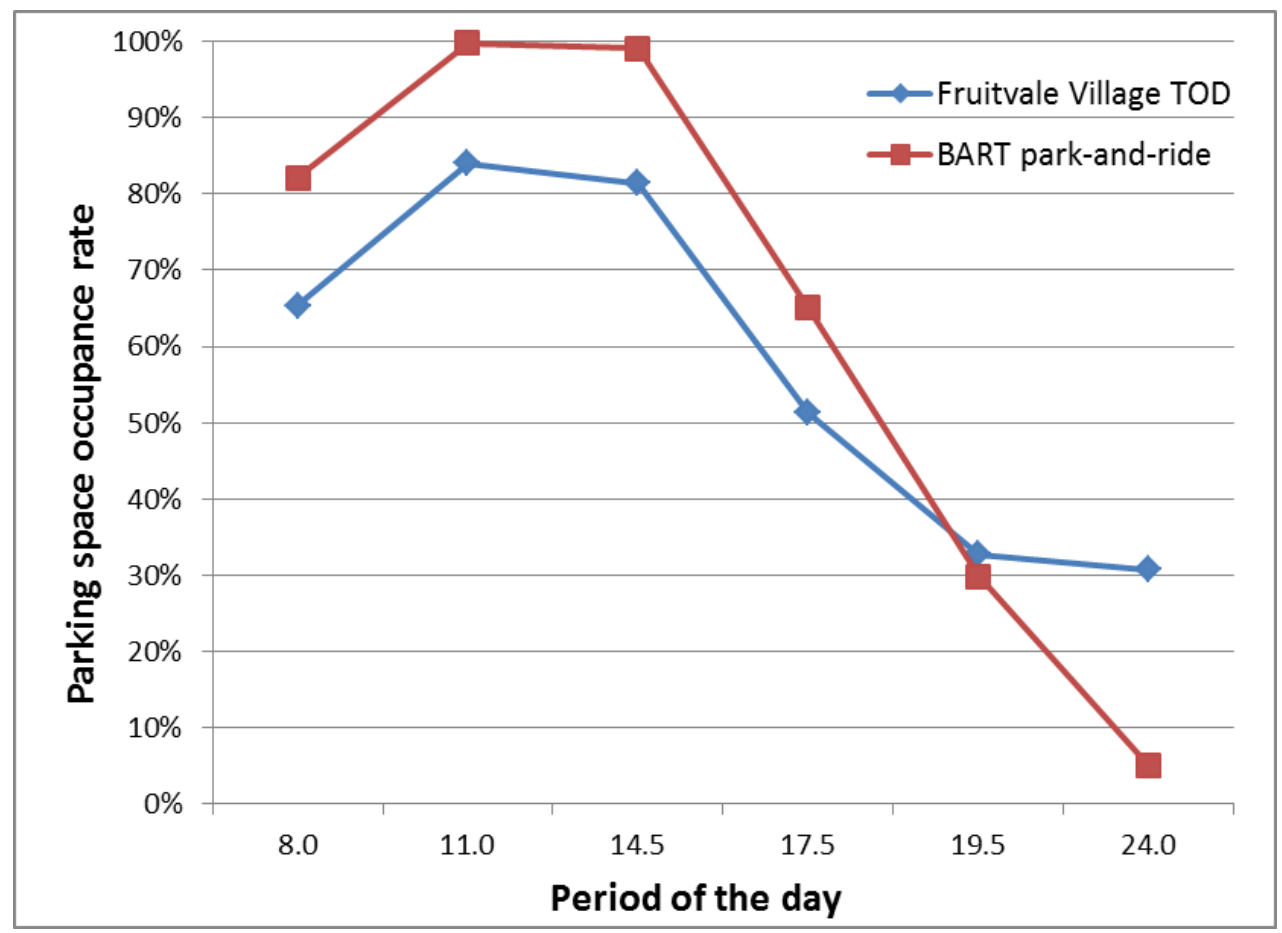

Figure 4.7. Parking Space Occupancy Rate for Different Uses at Fruitvale Village TOD

\section{Discussion}

The results of data analysis for this case study are somewhat surprising. First, walk mode share is much higher than any previous TODs studied in this report. Fruitvale has a walk-mode share of over 28 percent. This site was also the only location that has a bike-mode share higher than the nationwide average (over 4 percent). Additionally, transit-mode share is markedly higher than the previous two case studies. The combined mode share for transit was an impressive 42 percent. These high shares for active transportation modes mean that little room is left for the automobile. Fruitvale TOD has an automobile-mode share of only 23 percent. This is one third the San Francisco regional average of 81 percent, and it is the lowest observed auto-mode share of any TOD in the report.

Vehicle trip-generation rates for Fruitvale are somewhat anomalous, though. Fruitvale showed vehicle trip-generation rates a little over one half of ITE estimates, where the previous two case studies generated just over one third of ITE estimates. The high vehicle trip-generation rate at Fruitvale is especially perplexing when considering its high rates of travel by non-auto modes. The most obvious explanation for the dichotomy of low auto mode share but comparatively higher vehicle trip generation would be that 
Fruitvale is a vibrant retail center, and as such, is producing more daily trips relative to ITE estimates than our other case studies. One potential validation of such an assertion is the fact that Fruitvale is performing much better in terms of commercial and retail occupancy than the other sites. Being the oldest of our study sites, it seems reasonable to suggest that TOD retail and commercial occupancy improves over time as the market adjusts and the customer base becomes more accustomed to the different development pattern and its associated relationship to transportation.

Parking generation is yet another important point of comparison between Fruitvale and the two preceding case studies. Midday parking occupancy rates for the BART park-and-ride structure neared 100 percent. This is comparable to the findings from Rhode Island Row, which is the most similar peer TOD to Fruitvale, as it is also served by a heavy rail line with frequent service. However, residential parking occupancy rates were much lower at Fruitvale than at Rhode Island Row or Redmond. This is consistent with the exceptionally low auto mode share observed. In total, parking-generation rates at Fruitvale were only 27 percent of ITE's estimate for a similar development within a suburban, auto-oriented context. This remarkably low parking-generation rate is far below the values found at other study sites. 


\section{Chapter 5: Englewood TOD, Denver Region'}

The Englewood TOD, part of CityCenter Englewood, is located in Englewood, Colorado, a first-ring suburb south of Denver. CityCenter Englewood is directly served by Englewood Station on the region's light-rail Southwest Line. It is among the first such projects in the U.S. to replace an enclosed regional shopping mall with an open air, mixed-use development. This 55-acre planned unit development (PUD) focuses on a central public place with civic and cultural uses, retail and office space, apartments, a public library, and a light-rail transit station. The TOD portion of CityCenter is 38 acres on the western portion of the site, abutting the rail line. At 41 units per net acre and 15 units per gross acre, Englewood TOD is the least dense of the TODs studied (except Fruitvale Village, which is largely nonresidential). The remainder of the CityCenter site is occupied by big-box retailers, including a Wal-Mart.

Englewood TOD seems more auto-oriented than the other TODs studied. Streets enclose the development, with West Hampden Avenue (US-285) to the south, South Santa Fe Drive (US-85) to the west, West Floyd Avenue to the north, and South Elati Street to the east. South Inca Street runs through the development. The City's comprehensive plan identifies US-85 and US-285 as major arterials serving the region, while West Floyd Avenue, South Elati Street, and South Inca Street are minor collectors. Due to the variety and amount of activity in the TOD site, traffic congestion is a frequent occurrence in the area. The surrounding land uses include commercial to the east, industrial to the south and west along the rail line, and single-family residential to the north.

The goal of a PUD is to group varied and compatible land uses, and Englewood planned CityCenter as three main zones (see Figure 5.1). Zone 1 consists of 12 parcels that make up the mixed-use, transitoriented component of the development. Zone 2 covers three parcels that are predominantly retail in nature, but design standards connect it with Zone 1 . Zone 1 is the big box portion. Zone 3, the primarily automobile-centric entrance, links the old town center to Zones 1 and 2. It is treated as part of the Englewood TOD.

${ }^{6}$ For this case study, we interviewed Harold Stitt of the City of Englewood. He supplied extensive reports and graphic materials. 


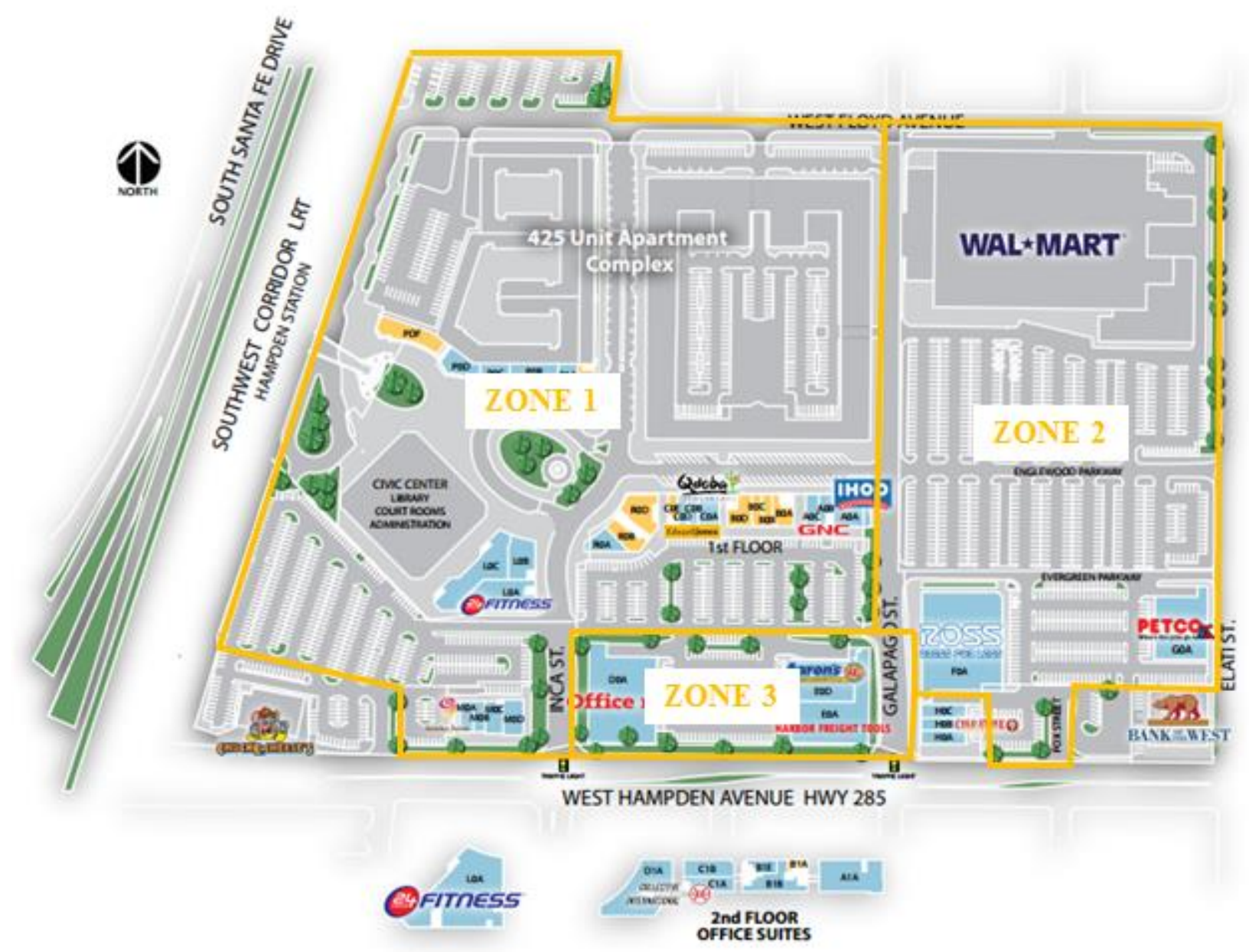

Figure 5.1. CityCenter Englewood with Its Three Zones of Development

\section{History}

The Cinderella City Mall opened in 1968 as the largest indoor mall west of the Mississippi River. Its 1.3million square feet stood on what is now the site of CityCenter Englewood. In 1974, the Cinderella City Mall accounted for nearly 52 percent of Englewood's municipal sales tax revenue. The Cinderella City Mall thrived for many years, but by the early 1990s, it succumbed to competition from newer suburban malls. Near its end, the mall accounted for only 2.6 percent of the city's tax revenue. 


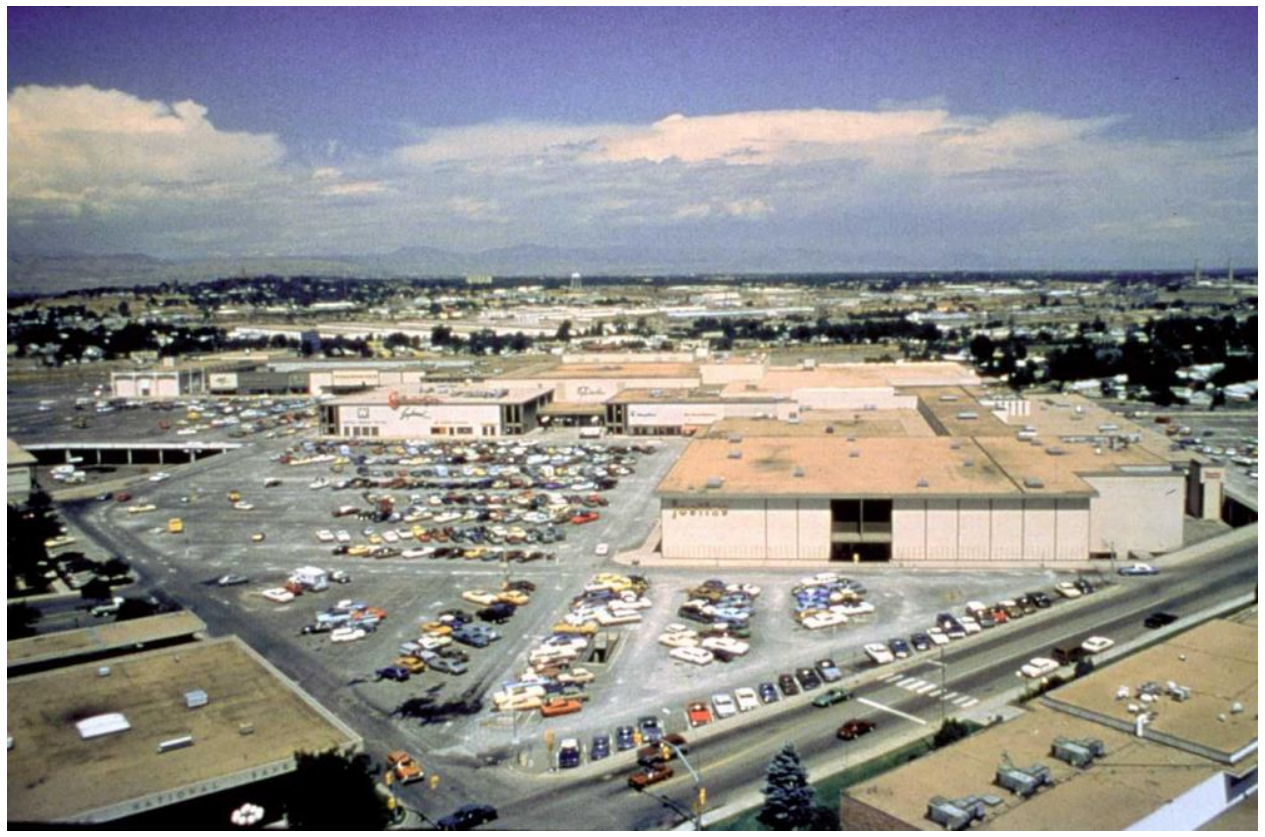

Figure 5.2. Aerial View of Cinderella City Mall

This decline prompted Englewood to brainstorm different uses for the site. In 1993, the city asked MAS Marketing to study future community needs and hired Clarion Associates to begin public discussions on the future of the site. The study findings and subsequent discussions influenced Englewood to issue a request for proposals in 1994. Most of the proposals envisioned demolishing the mall and replacing it with big-box retail stores. In January 1995, a city advisory group recommended a proposal by MillerKitchell for an entertainment/retail complex.

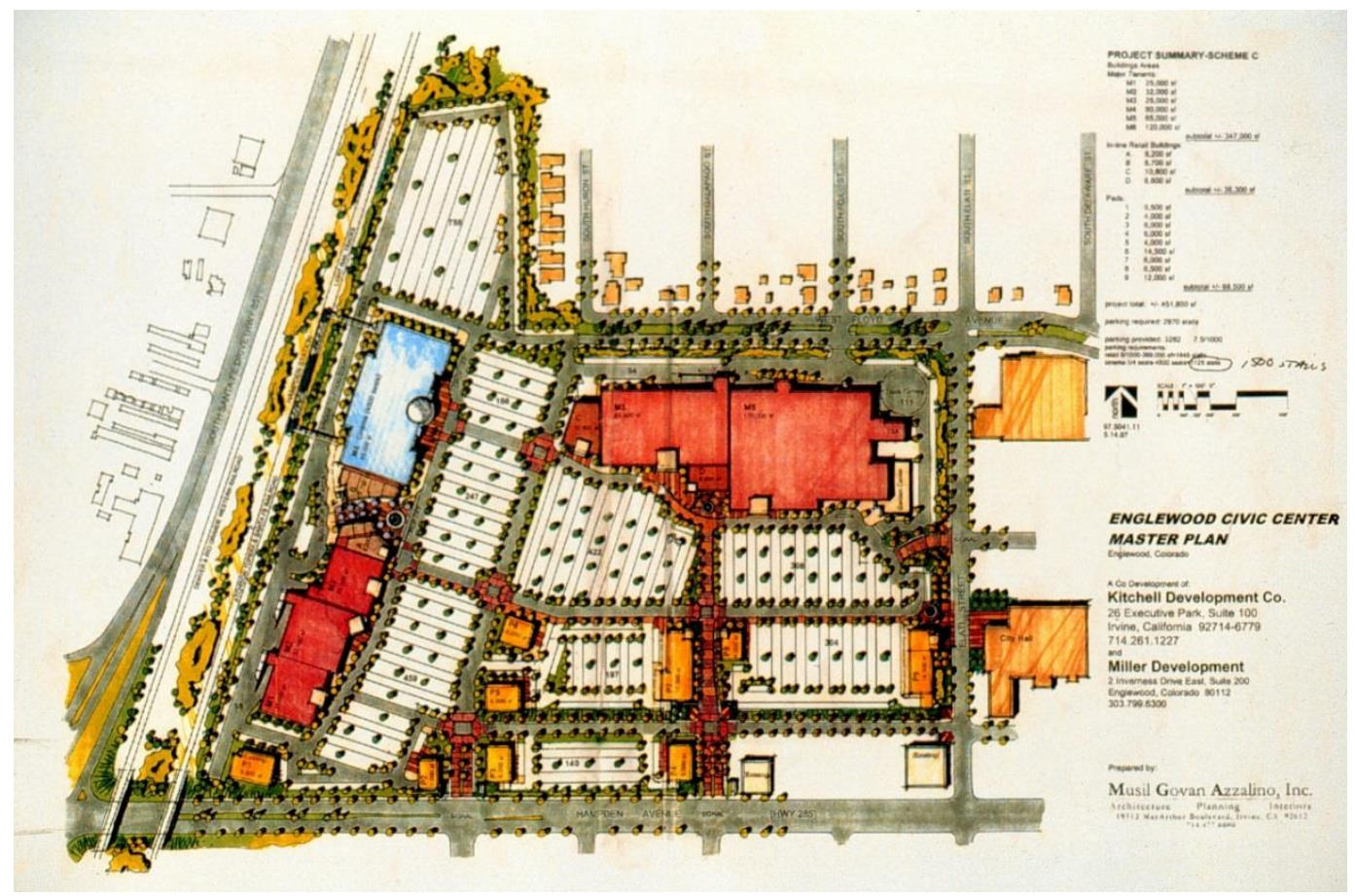




\section{Figure 5.3. Original Miller-Kitchell Plan}

By 1996, market conditions had changed, and the public was less supportive of a predominantly retailoriented project. Also, the Regional Transportation District (RTD) had finalized plans for a seven-mile extension of Denver's light rail (LRT) system that would reach southwest to touch Englewood. This decision inspired the city to consider the potential of a transit-oriented development on the site.

In 1997, the city's nonprofit redevelopment agency, the Englewood Environmental Foundation (EEF), acquired the Cinderella City Mall property and assumed the role of master planner and master developer. As master developer, EEF undertook a $\$ 3$ million asbestos and greyfield site cleanup to reduce the risk to potential developers and financial backers. The cost was split with the previous owners.

Also in 1997, Englewood hired RNL Design to conduct a study of community needs that could be met by the TOD. Identified needs included municipal office space, increased library space, public open space, and arts and cultural activities.

By 1998, the demolition of the Cinderella City Mall had begun, with TOD construction beginning shortly thereafter and completed by 2001. In 2000, the Southwest Light Rail Transit Line opened. Figure 5.4 is a timeline of the transformation from the Cinderella City Mall to the TOD.

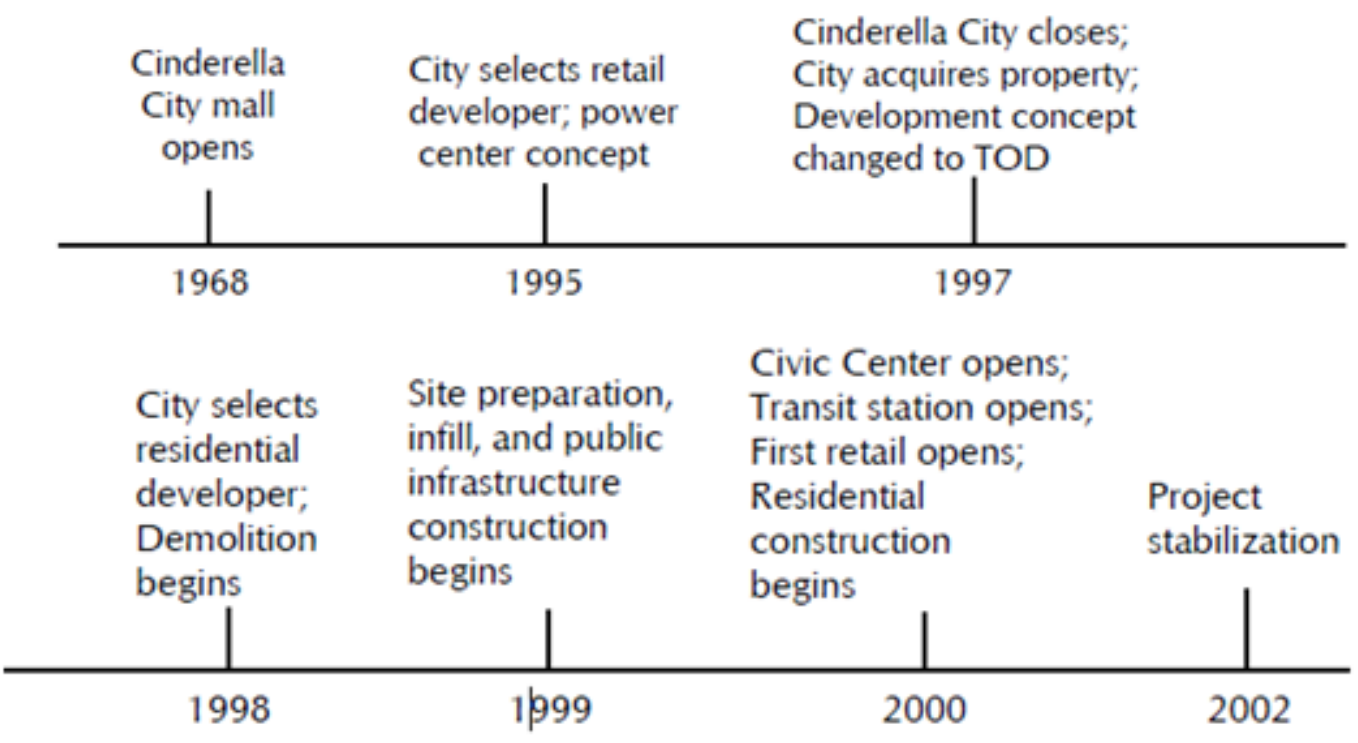

Figure 5.4. Timeline of the Mall-TOD Conversion

The actual of redevelopment of the site stretched the city's resources. While partnership agreements with private developers were advantageous to get the project going, Englewood wanted to retain control and act as the master developer of the project to ensure the community's best interests. Thus, to help fund the development, Englewood issued \$22 million in certificates of participation (COPs) instead of relying on general obligation bonds and tax increment financing (TIF). Government-issued bonds would have required a public vote. Instead, Englewood spent \$11 million of the money raised through COPs renovating Foley Department Store into a new civic building. The other $\$ 11$ million went to streets, parks, plazas, and other basic infrastructure for the site. 
To help finance the rest of the development, Englewood leased and sold portions of the redevelopment site. The city's partnerships and their financial contributions are listed in Table 5.1.

\section{Table 5.1. Initial Private and Private Investments in CityCenter Englewood}

\begin{tabular}{|l|l|r|}
\hline Funding Source & Type & \multicolumn{1}{c|}{ Revenue } \\
\hline City of Englewood & General Fund monies and COPs & $\$ 18,500,000$ \\
\hline Regional Transportation District & Transit improvements & $\$ 5,700,000$ \\
\hline Miller-Weingarten & Long-term lease & $\$ 4,200,000$ \\
\hline Trammell Crow Residential & Purchased property & $\$ 5,000,000$ \\
\hline Wal-Mart & Purchased property & $\$ 3,400,000$ \\
\hline & & TOTAL \\
\hline
\end{tabular}

Englewood initially hired Calthorpe Associates, a firm famous for its New Urbanist plans, to design the original TOD with a mix of uses, but then used a local firm to design the final project (see Figure 5.5). When the site was a mall, it was zoned B-1, general business district, Englewood rezoned it as a PUD when planning the TOD to accommodate flexible redevelopment and a mix of uses.
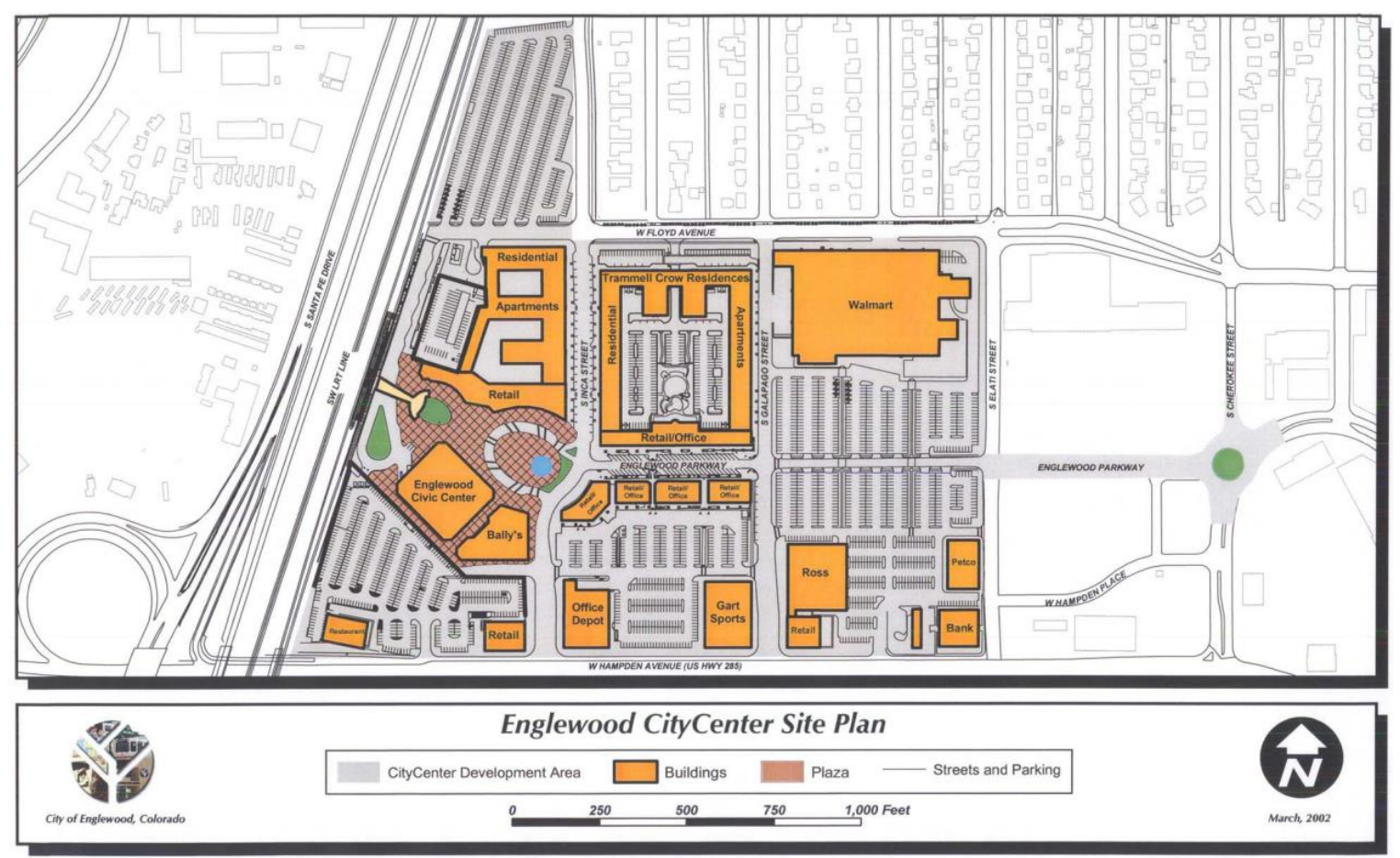

Figure 5.5. Final Site Plan (http://www.englewoodgov.org/home/showdocument?id=659)

\section{Transit Connection}

Both light rail and bus lines serve the Englewood TOD. Denver RTD connects downtown Denver with two light-rail lines, the $\mathrm{C}$ Line and the D Line (see Figure 5.6). Both run parallel to US-85. The D Line was part of Denver's first phase of LRT development, while the C Line opened later, in 2002. The C Line runs 30-minute headways during weekdays with no service on weekends. The D Line has 15-minute headways during peak hours, runs longer hours during the weekdays, and has service on weekends. After 
the Englewood station opened, bus routes throughout the city adjusted to provide better connectivity and complementarity to the LRT system.

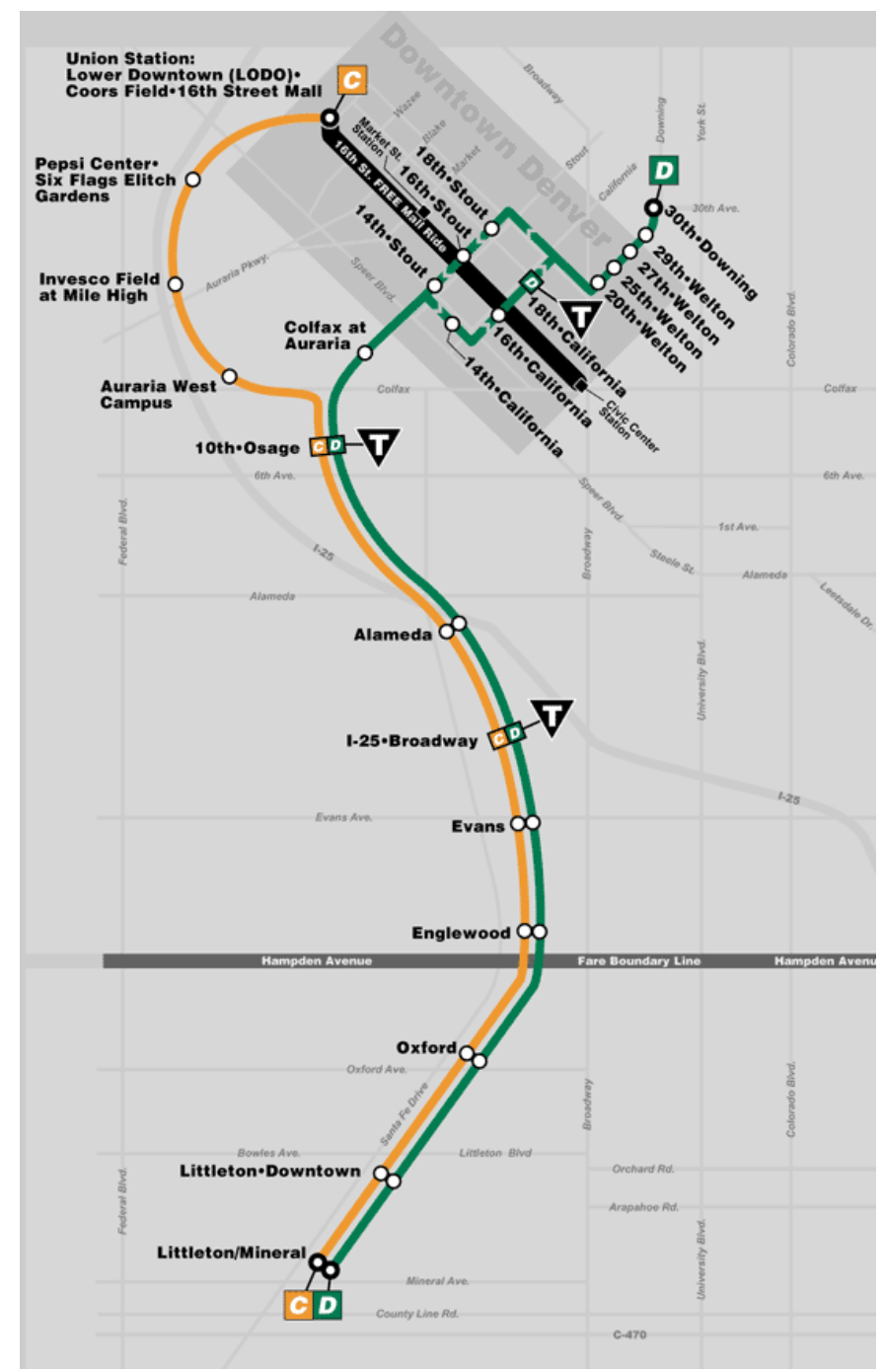

Figure 5.6. Rail Map. Source: RTD Denver Website

Half a dozen bus routes, including South Broadway (0), South Downing (12), Yale Crosstown (27), Hampden Crosstown (35), Sheridan Crosstown (51), and Pine Junction/Conifer/DTC Regional (U), serve the Englewood TOD. The city has also organized a free shuttle bus directly connecting CityCenter with downtown and the hospital district to the east. The shuttle operates only on weekdays with 15-minute headways. Most RTD buses run on 30-minute headways, but some serve 15-minute headways during peak hours. While transfer information from bus to rail is not yet available, an RTD Light Rail Passenger Survey conducted in 2000 found that 29 percent of passengers accessed the light rail by bus. The remainder of passengers drove alone (48\%), walked (12\%), carpooled (7\%), biked (2\%), or used another mode $(2 \%)$ to reach LRT stations. 
Both rail and bus ridership have been steady since the TOD opened. In 2000, the year it opened, a weekday ridership count found 1,626 passengers heading northbound (toward Denver) and 157 passengers heading southbound.

For cyclists, the site boasts 24 bike racks and 32 bike lockers to encourage bike use. While the design of the TOD itself is considerate of pedestrians and bicyclists, the connectivity to the site appears to be lacking for these mode users. In fact, Englewood's 2003 comprehensive plan identifies the need for improved pedestrian access across US-285 (Hampden Avenue) to CityCenter. Both the new comprehensive plan for the city and its grant-funded bicycle routes improvements plan emphasize linking the TOD with better biking and pedestrian infrastructure over time.

\section{The Development Itself}

CityCenter Englewood consists of more than 800,000 square feet of development, including 438 residential units, 330,000 square feet of retail (including big box), 300,000 square feet of offices, 50,000 square feet of restaurant space, and a light rail station. A former department store is now a 135,000 square foot civic center hosting a library, municipal courts, city offices, and a museum (see Figure 5.7). Englewood Parkway is the "main street" of CityCenter, running east-west down the center of the development. Englewood Parkway's design includes traffic calming treatments such as on-street angled parking, bulb outs and crosswalks, small buffers, and pedestrian uses such as benches. The heart of the TOD is a two-acre public piazza that opens to the light-rail station via a 110-foot steel truss bridge. At the base of the bridge is an outdoor amphitheater that provides performance space for music, films, dance, and community activities.

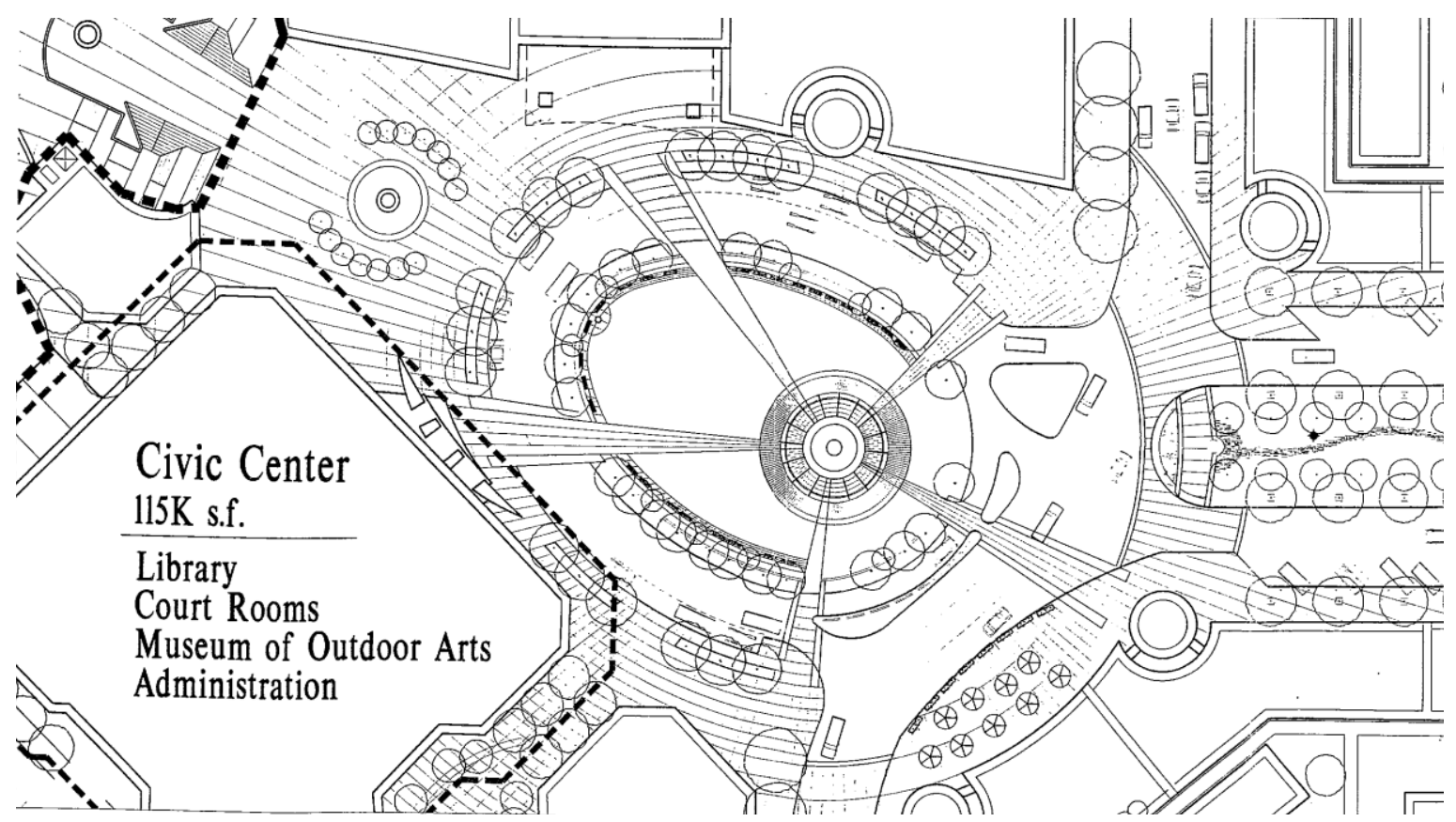

Figure 5.7. Civic Center and Piazza

Two large mixed-use buildings contain residential units and a variety of retail and other commercial uses. Both are three stories high in a perimeter block housing style with internal courtyards. The buildings are 
adjacent to each other with South Inca Street between them. The western residential building faces south to the main pedestrian retail corridor that leads to the transit station. Opposite the western mixed-use building are four commercial buildings containing restaurants, retail spaces, a pharmacy, and medical offices.

Residential occupancy rate for CityCenter is in line with the Denver market at upwards of 95 percent. The TOD's office occupancy rate is 100 percent, which is above the rate for both Denver ( 90 percent) and Englewood (80 percent) as a whole. Table 5.2 compares the average rents in CityCenter to the rest of Englewood. Average rents are almost twice as high in CityCenter.

Table 5.2. Average Market Rents for CityCenter and Englewood (Source: City of Englewood; Raising the Bar Urban Land)

\begin{tabular}{|l|c|c|}
\hline \multicolumn{1}{|c|}{ Space } & CityCenter & City of Englewood \\
\hline Class A Office & $\$ 21.00-\$ 25.00$ gross & $\$ 13.50-\$ 17.00$ \\
\hline Retail & $\$ 18.00-\$ 20.00 \mathrm{NNN}$ & $\$ 8.50-\$ 14.00 \mathrm{NNN}$ \\
\hline Residential & $\$ 1,005-\$ 1,735$ per month & $\$ 500-\$ 750$ \\
\hline
\end{tabular}

Tables 5.3 and 5.4 summarize land use within the Englewood TOD. These figures inform our analyses of trip and parking generation. They do not include the big box retailers in Zone 2.

Table 5.3. Development Summary of Englewood TOD (38 acres)

\begin{tabular}{|c|c|c|c|}
\hline Land uses & Description & Unit & Occupancy* \\
\hline Commercial & & 332,884 sq. ft. & $93 \%(309,546)$ \\
\hline \multirow[t]{2}{*}{ Residential } & \multirow[t]{2}{*}{3 stories } & $\begin{array}{l}211 \text { units (801 Apartment } \\
\text { Complex, northeast block) }\end{array}$ & $98.5 \%$ (208 units) \\
\hline & & $\begin{array}{l}227 \text { units (901 Apartment } \\
\text { Complex, west block) }\end{array}$ & $97.7 \%$ (222 units) \\
\hline Parking & Description & Unit & Occupancy*** \\
\hline $\begin{array}{l}\text { Regional } \\
\text { Transportation District } \\
\text { (RTD) Park-and-Ride }\end{array}$ & Surface parking & $\begin{array}{l}595 \text { stalls (for RTD light } \\
\text { rail and bus users, no } \\
\text { overnight parking } \\
\text { allowed) }\end{array}$ & $\begin{array}{l}99 \% \text { (only } \\
\text { handicap spaces } \\
\text { were vacant) }\end{array}$ \\
\hline $\begin{array}{l}\text { West Block North } \\
\text { (WBN) Parking } \\
\text { Structure }\end{array}$ & $\begin{array}{l}\text { 4-level parking structure, } \\
\text { which is gate controlled - } \\
\text { key car access only }\end{array}$ & $\begin{array}{l}354 \text { stalls for residents of } \\
901 \text { Apartment Complex } \\
\text { and employees of } \\
\text { retail/office (which is } \\
\text { small amount) }\end{array}$ & $62.7 \%$ \\
\hline $\begin{array}{l}\text { West Block South } \\
\text { (WBS) Parking } \\
\text { Structure }\end{array}$ & $\begin{array}{l}\text { 2-level parking - parking is } \\
\text { free }\end{array}$ & $\begin{array}{l}738 \text { stalls shared among } \\
\text { retail, office, and RTD } \\
\text { users ( } 315 \text { stalls for RTD } \\
\text { users) }\end{array}$ & $86 \%$ \\
\hline $\begin{array}{l}\text { Southeast Block (SEB) } \\
\text { Surface Parking }\end{array}$ & $\begin{array}{l}\text { Surface parking. Parking is } \\
\text { free. } 2 \text { hour parking in } \\
\text { some locations, others are } \\
\text { not limited }\end{array}$ & $\begin{array}{l}365 \text { stalls for retail and } \\
\text { office uses }\end{array}$ & $47.7 \%$ \\
\hline
\end{tabular}




\begin{tabular}{|l|l|l|l|}
\hline $\begin{array}{l}\text { Northeast Block } \\
\text { (NEB) Surface Parking }\end{array}$ & $\begin{array}{l}\text { Surface parking for resident } \\
\text { of 801 Apartment Complex } \\
\text { and visitors }\end{array}$ & $\begin{array}{l}248 \text { stalls inside gate and } \\
56 \text { stalls outside of gate }\end{array}$ & $91.1 \%$ \\
\hline $\begin{array}{l}\text { Englewood Parkway } \\
\text { (EP) On-Street Parking }\end{array}$ & On-street 2 hour parking & $\begin{array}{l}65 \text { stalls (50 stalls on the } \\
\text { North and South side for } \\
\text { retail, office, and } \\
\text { residential, 15 stalls in the } \\
\text { Circle for retail and office) }\end{array}$ & $78.5 \%$ \\
\hline $\begin{array}{l}\text { Inca St On-Street (IS) } \\
\text { Parking }\end{array}$ & On-street 2 hour parking & $\begin{array}{l}\text { 42 stalls (primarily } \\
\text { residential users, but open } \\
\text { to all public) }\end{array}$ & $90.5 \%$ \\
\hline
\end{tabular}

*On October 13, 2015

**The peak occupancy on October 13, 2015

Table 5.4. Commercial Uses in Englewood TOD

\begin{tabular}{|c|c|c|c|}
\hline Land uses & Lessee & Unit (sq.ft.) & Total Unit (sq. ft.) \\
\hline \multirow[t]{3}{*}{ Civic Center } & Englewood Public Library & 31,000 & \multirow{3}{*}{139,000} \\
\hline & $\begin{array}{l}\text { Museum of Outdoor Arts \& Hampden } \\
\text { Hall }\end{array}$ & 14,855 & \\
\hline & Government administration offices & 93,145 & \\
\hline \multirow{28}{*}{ Businesses } & IHOP & 4,243 & \multirow{28}{*}{170,546} \\
\hline & Nails & 1,404 & \\
\hline & GNC & 1,430 & \\
\hline & City Center Dental & 7,209 & \\
\hline & Community Care & 3,424 & \\
\hline & Tableaux Interiors & 548 & \\
\hline & XL Edge & 1,367 & \\
\hline & Qdoba & 2,253 & \\
\hline & Edward Jones & 1,132 & \\
\hline & Collective Licensing International & 2,915 & \\
\hline & XL Edge & 3,364 & \\
\hline & Office Depot & 22,857 & \\
\hline & Collective Licensing International & 10,284 & \\
\hline & Harbor Freight Tools & 15,048 & \\
\hline & Aaron's & 9,700 & \\
\hline & Dr. Newman Optometrist & 2,392 & \\
\hline & UniFocus & 2,303 & \\
\hline & Nixon's Café & 1,543 & \\
\hline & State Farm & 1,371 & \\
\hline & Lifetime Family Practice & 1,200 & \\
\hline & King Liquor & 1,494 & \\
\hline & Let it Bead & 950 & \\
\hline & CO Chiropractor & 1,150 & \\
\hline & Cuttn It Loose & 1,994 & \\
\hline & 24 Hour Fitness & 27,216 & \\
\hline & Max Four & 8,600 & \\
\hline & Blondies Fire House Grill & 3,610 & \\
\hline & Jamba Juice & 1,543 & \\
\hline
\end{tabular}




\begin{tabular}{|l|l|r|}
\hline \multirow{3}{*}{} & Fit Kitchen & 1,335 \\
\cline { 2 - 3 } & Doctors Express & 2,185 \\
\cline { 2 - 3 } & Tokyo Joes & 2,701 \\
\cline { 2 - 3 } & Chuck E. Cheese's & 12,179 \\
\cline { 2 - 3 } & Bleum & 3,008 \\
\cline { 2 - 3 } & MCPN & 2,339 \\
\cline { 2 - 3 } & Creator Mundi & 2,704 \\
\cline { 2 - 3 } & BRI Colorado & 1,551 \\
\hline
\end{tabular}

\section{Parking Situation}

The total number of parking spaces within CityCenter, including the spaces in the Wal-Mart parking lot, is approximately 2,810. This may seem like a large amount of parking, but the number of spaces would have been closer to 3,400 if the City and the RTD had not negotiated shared parking. Walker Parking Consultants analyzed the type and quantity of the development's program elements and their parking requirements for different times of the day. The study concluded that certain uses (retail, civic, and cultural) would peak during daytime hours while others (restaurants and the health club) would peak in the evening. This study was one of the guides to parking standards for CityCenter.

The surface park-and-ride lot to the north of the station contains 610 spaces. The parking garage south of the civic center has 800 spaces in the parking garage, 300 of which are available to transit users. The 500 remaining spaces in the garage are for the civic center and its adjacent retail uses. There is another primarily residential parking garage on the site, but the rest of the spots are surface lots. Figure 5.8 shows a parking map of the types of parking available in the TOD. There is a dramatic difference between this map and the site plans of the other TODs studied, which place parking in structures.

A development agreement between Wal-Mart and EEF stipulated that certain parking ratios would be maintained across the entire CityCenter Englewood site, including 1.5 spaces per dwelling unit. These parking ratios, in many cases, were greater than those recommended by the Walker Parking Study and the City's own parking requirements. It is clear that, at least in terms of parking negotiations, Wal-Mart had the upper hand and viewed the CityCenter Englewood TOD as just another suburban infill development which, coincidentally, happened to be adjacent to a light rail transit line.

There is an upside to the large amount of surface parking at CityCenter Englewood. Surface parking can be considered as land banking for a more transit-centric and less auto-centric future. In that future, the vast acreage of RTD park-and-ride lot could shrink considerably and become potential office or residential infill sites filled with transit patrons of all stripes. Likewise, a big box is just that, a box, four walls and a roof. In the CityCenter Englewood case, if and when Wal-Mart departs for a more fertile landscape, the 13 acres become a major urban infill site just begging for mixed-use development. 


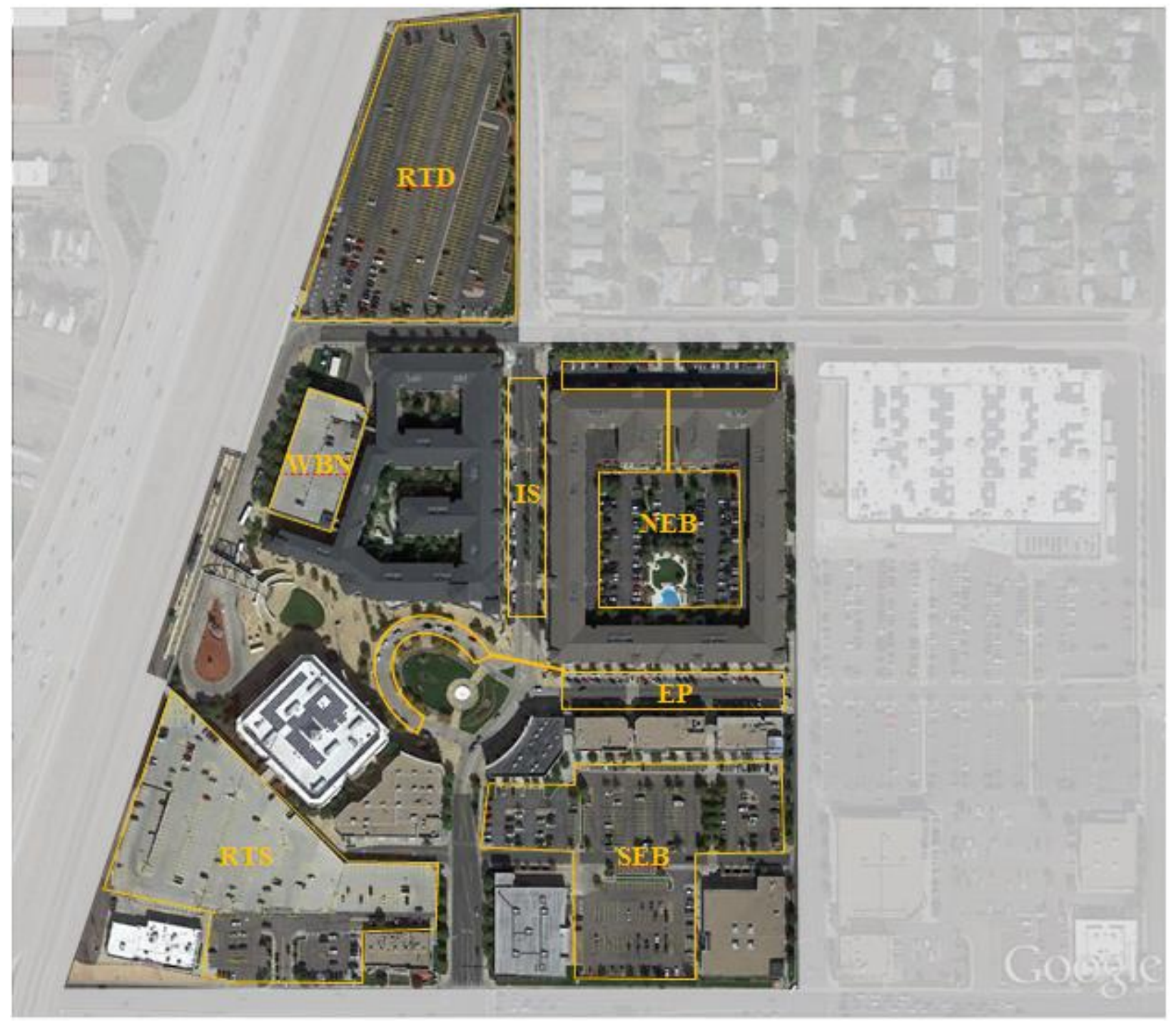

Figure 5.8. Parking spaces at Englewood TOD
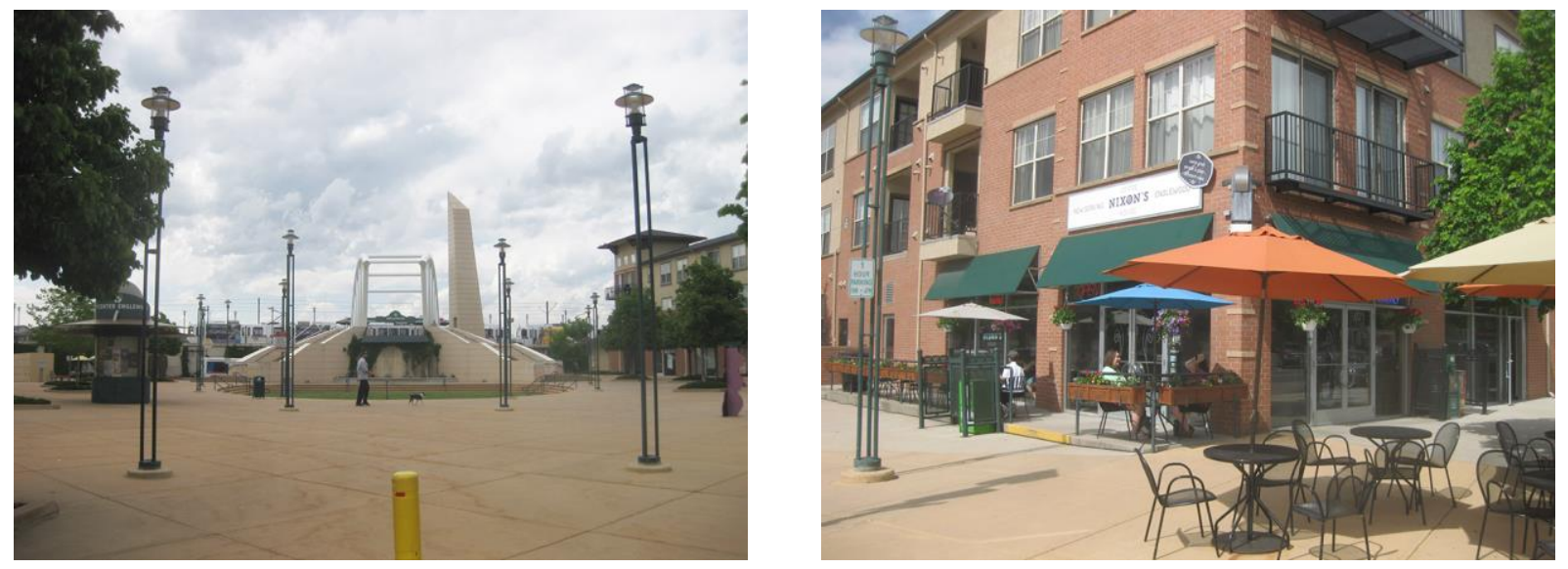
(a) Piazza, amphitheater, and bridge to station

(b) Apartments above shops

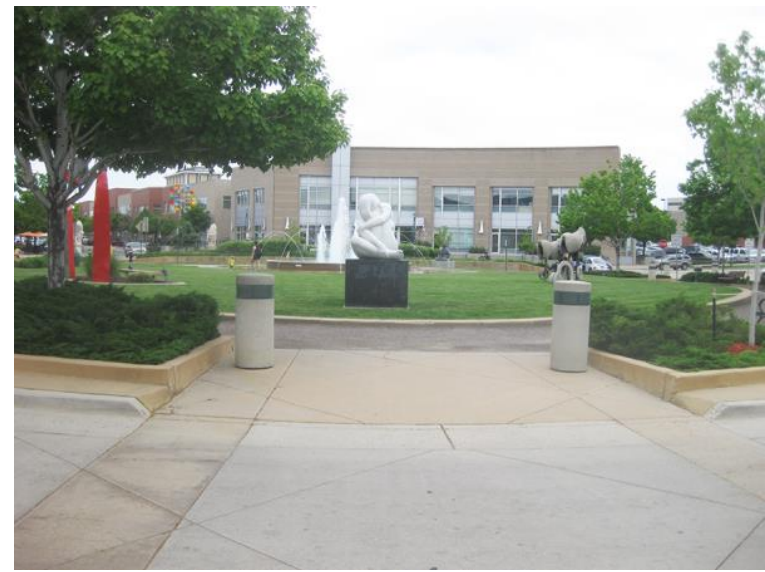

(c) Central park and public art gallery

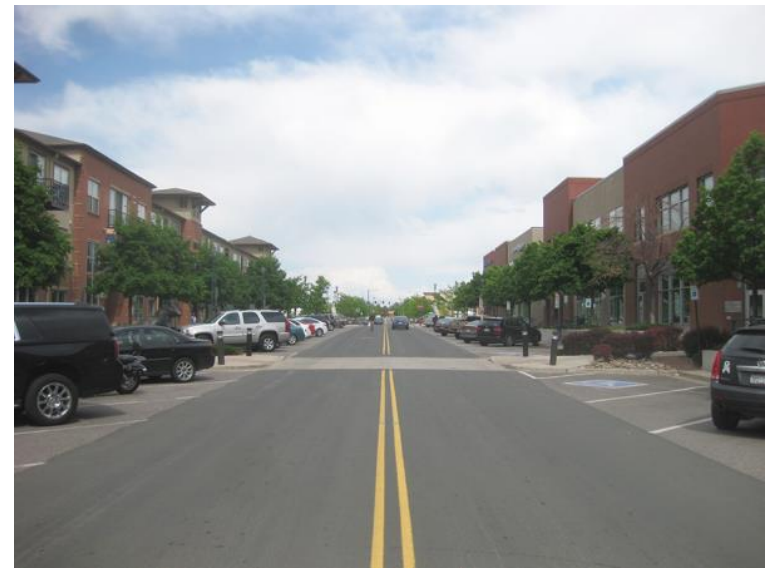

(e) Traffic calmed Englewood Parkway

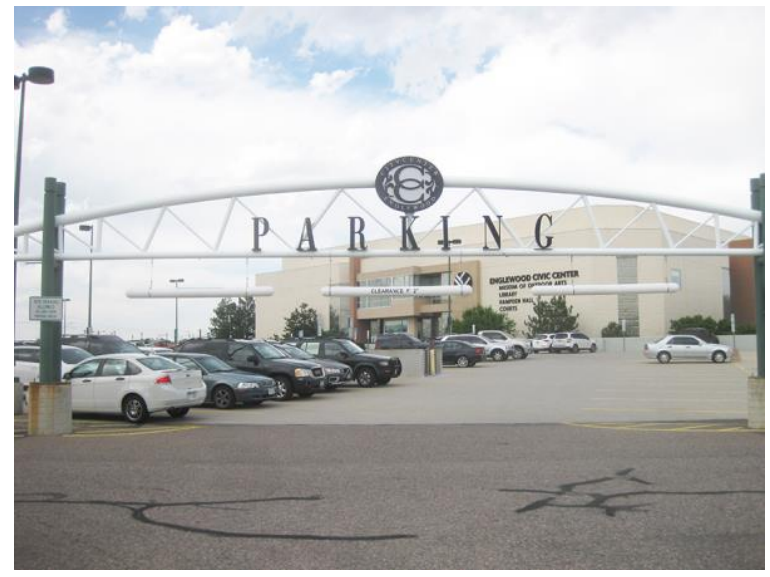

(g) Free parking behind Civic Center

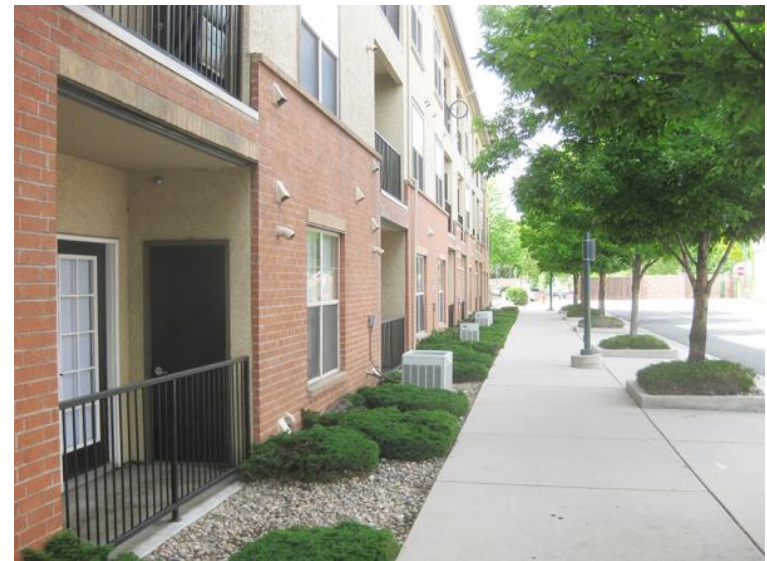

(d) Apartments turning back on big box retail

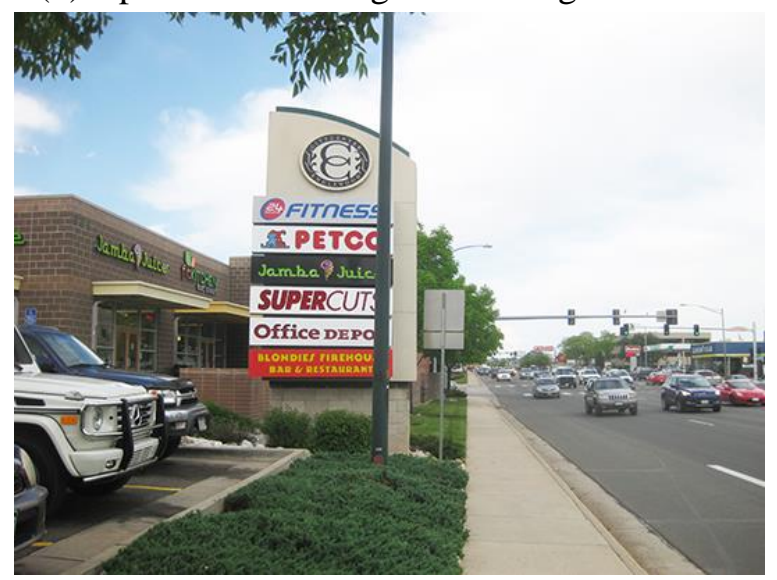

(f) Auto-oriented development along US-285

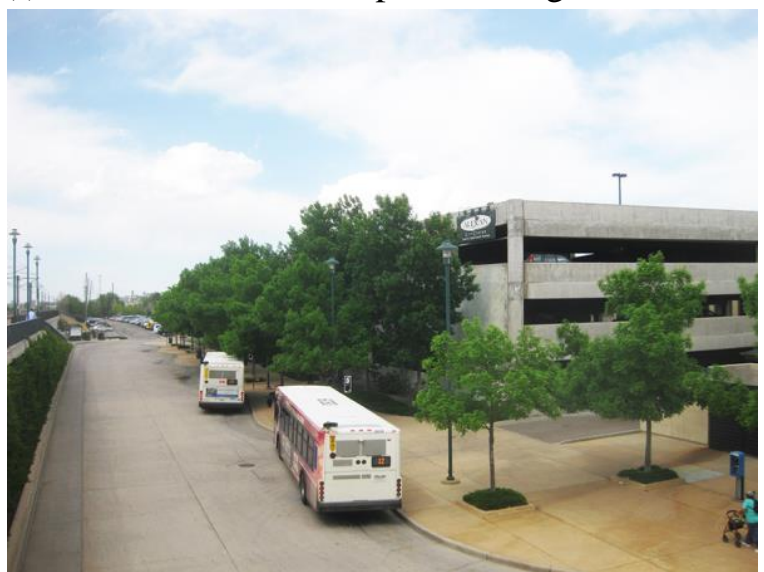

(h) Bus transfer area seen from station 


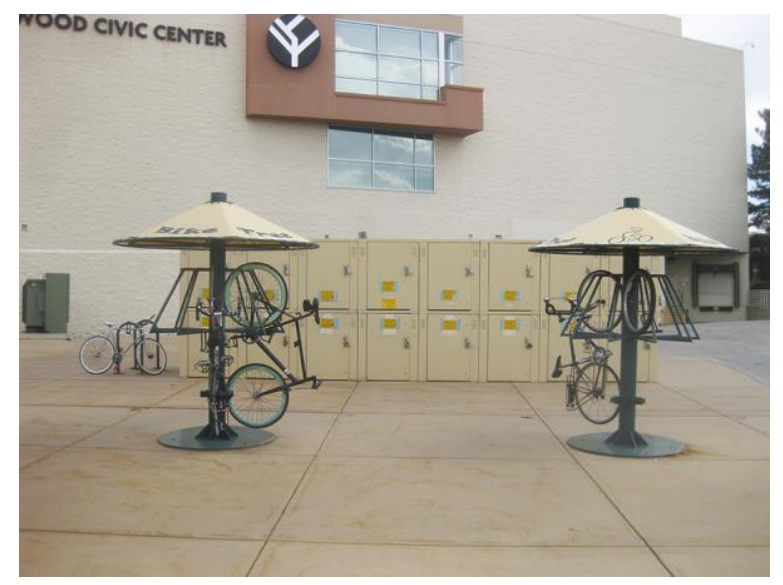

(i) Bike parking at station

Figure 5.9. Englewood TOD

\section{Data Collection}

The multimodal transportation planning and engineering firm of Fehr \& Peers developed a data collection plan and protocols, and managed data collection in the field and subsequent data entry for four types of travel data: (1) a full count of all persons entering and exiting the twelve buildings (unless captured by the vehicle accesses) that make up Englewood, (2) a brief intercept survey of a sample of individuals entering and exiting the buildings, (3) parking inventory and occupancy counts of all off-street parking accessory to the commercial and residential uses of the buildings, and the co-located, but separate off-street parking facility owned and operated by the Regional Transportation District (RTD) for all day use by transit riders, and (4) parking inventory and occupancy counts for on-street parking on Englewood Parkway.

The intent of this approach was to develop an accurate measure of total trip generation associated with the commercial and residential space at the site, as well as a complementary sample of travel survey and parking utilization data that could be weighted by hour to provide a picture of the mode of travel, origin/destination, parking location - if applicable- and purpose of all trips to and from the building throughout the course of the day.

All survey and trip count data were recorded on location in Englewood, between 7:00 am and 9:00 pm on Tuesday, October 13, 2015. The survey and trip count data were performed by temporary staff. Professional counting staff from All Traffic Data assisted with recording video counts at four vehicle driveway locations. The video counts were later used by Fehr \& Peers staff to count the entering and exiting vehicles and the occupancy therein. In addition, to determine parking occupancy during the anticipated period of peak utilization associated with the residential use, an "overnight" count of parking occupancy was conducted at all surface parking lots, on-street parking areas, and the one parking garage around midnight. Some of the temporary staff were not always dedicated to performing their tasks at a high level, which required the Fehr \& Peers' supervisor to stay on top of this staff to ensure the more accurate data collection. In two cases, the temporary staff were asked to leave because of their lack of commitment to accurately collect the data. In these situations, we were able to cover the vacant spots with the other staff in the respective areas. The professional counting staff performed at a higher level with less supervision required. 
For the purpose of counting person trips generated and recording travel patterns, separate teams of surveyors were employed to (a) count people entering/exiting at each building entrance, and (b) conduct intercept surveys. All parking inventory and occupancy counts were conducted by Fehr \& Peers planning staff, who also supervised survey workers at building entrances.

Throughout the survey period, 28 people were employed to conduct trip counts. These surveyors were stationed on the public sidewalk in fixed positions where they could easily and continually observe all primary entrances to the buildings, off-street parking lot and garage entrances, and on-street parking locations. Two surveyors (Fehr \& Peers staff) were full-time floaters and traveled amongst all the survey locations to ensure accuracy, answer questions, and to relieve the surveyors for periodic breaks. Care was taken to eliminate as much as possible the double counting of an individual that could occur from pedestrians exiting the parking garage and then entering a commercial doorway and/or a pedestrian entering/exiting a vehicle parked in on-street and surface parking stalls and then entering/exiting a commercial doorway. Each counter observed nearby on-street parking to verify if individuals entering/exiting on-street parked vehicles accessed the commercial or residential doorways that he/she was responsible for - individuals would be counted as a vehicle and not a pedestrian in these circumstances.

The counter locations are illustrated in Figure 5.10. For the West Block (WB), the camera location WB1 recorded vehicles entering/exiting the driveway on Hampden Avenue. The camera was strategically placed to capture video of the vehicle occupancy when visible. This camera also captured pedestrians entering/exiting the Chuck E Cheese establishment. The WB2 counter tallied the number of people entering/exiting the retail establishments on the southeast corner if they accessed from off the sidewalk on Hampden Avenue. Otherwise most users at this location had parked in the adjacent parking garage/lot and were therefore not counted since they were captured in the vehicle counts. The WB3 counter tallied pedestrians entering/exiting the fitness center, but not those who had parked in the adjacent parking lot/garage. WB3 also counted the vehicles (and occupancy) entering/exiting the parking driveway on Inca Street. Counters WB4, WB5, and WB6 recorded pedestrians entering/exiting their respective commercial and residential doors, as well as observing and counting the adjacent on-street parking stalls. If a vehicle parked in the on-street stall they would be counted as a vehicle (with occupancy noted) and not as a pedestrian when entering/exiting the respective doorways. The counter (WB7/PNR1) on the north side of the West Block recorded vehicles entering/exiting the West Block parking garage as well as the six RTD park-n-ride (PNR) lot accesses - noting vehicle occupancy when visible. The camera location PNR2 recorded vehicles entering/exiting the north access to the RTD lot on Inca Street. The camera was strategically placed to capture video of the vehicle occupancy when visible. The Northeast Block (NEB) counters at locations NEB1, NEB2, NEB3, and NEB6 recorded pedestrians entering/exiting their respective commercial and residential doors, as well as observing and counting the adjacent on-street parking stalls. If a vehicle parked in the on-street stall they would be counted as a vehicle (with occupancy noted) and not as a pedestrian when entering/exiting the respective doorways. Counters NEB4 and NEB5 recorded pedestrians entering/exiting the residential doors and also counted vehicles and occupancy, when visible, at the residential-only parking accesses. The Southeast Block (SEB) counters at locations SEB1, SEB2, and SEB3 recorded pedestrians entering/exiting their respective commercial and office doors, as well as observing and counting the adjacent on-street parking stalls. If a vehicle parked in the on-street stall they would be counted as a vehicle (with occupancy noted) and not as a pedestrian when entering/exiting the respective doorways. The camera locations at SEB4 and SEB5 recorded 
vehicles entering/exiting the driveways on Galapago Street and Inca Street, respectively. The cameras were strategically placed to capture video of the vehicle occupancy when visible. The SEB6 counter tallied the number of people entering/exiting the retail establishments on the south end if they accessed from off the sidewalk on Hampden Avenue. If customers entered/exited these two buildings from the surface parking lot, they were not counted since they were already captured from the SEB4 and SEB5 camera locations.

It should be noted that even with all the care taken to eliminate over-counting, this most likely occurred when individuals entered and exited more than one commercial doorway on-site and during peak times when numerous pedestrians were exiting the parking areas and couldn't be tracked to the doorways.

A separate team of surveyors - two all day - were employed to intercept and survey people entering and exiting the buildings. One surveyor was stationed in-between the Northeast Block and Southeast Blocks. The second surveyor was stationed in the West Block area. Both surveyors roamed the entire area of these blocks to capture individuals traveling to/from a mix of uses. The surveyors covered all primary pedestrian entrances to the main buildings, but were instructed to leave their stations, as necessary to intercept and attempt to survey individuals seen moving toward an entrance, or away from a building exit.

As a first step, surveyors noted whether the subject was observed "coming" or "going" to/from the building, and the type and location of entrance/exit used, and recorded the time of intercept by checking a box on the data collection form associated with one of four 15-minute periods per hour.

People leaving the buildings were asked: (1) "How do you plan to get to your next destination?" (e.g. by what mode of travel?), and (2) What is the purpose of your trip? (e.g., "Going home," "Going to work," "Shopping," or "other").

People arriving at the buildings were asked: (1) "How did you get here?" (e.g. by what mode of travel?), and (2) What is the purpose of your trip? (e.g., "home-bound," "work-bound," "shopping," "workrelated," or "other").

Individuals who indicated that they had arrived, or would be leaving by automobile were also asked where they had parked their vehicle (i.e., "on-street", "in the garage", or "other").

Surveyors counted and attempted to intercept only those individuals observed walking to or from an entrance to the buildings (or, in observation of the garage or surface parking lot entrances, only those drivers and passengers in vehicles entering/exiting the garage/lot driveway to/from the public street). Individuals waiting for the train or bus, or walking between the rail station and other trip origins/destinations, including the RTD park-and-ride lot, were not counted or surveyed. 


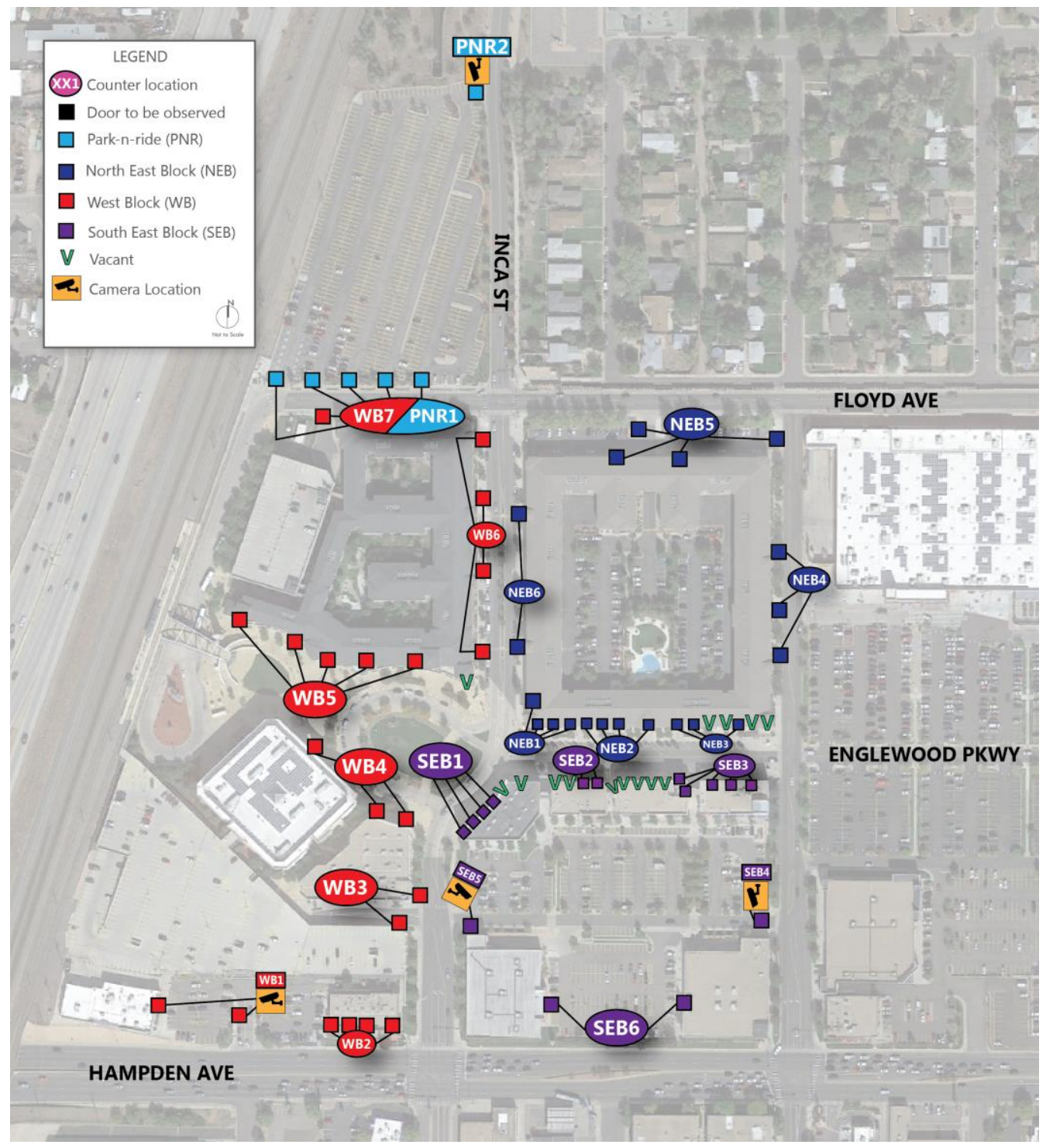

Figure 5.10. Englewood Counter and Survey Locations

\section{Mode Shares}

In the intercept survey, we had surveyors at building entrances to ask people questions. We received 530 valid surveys from 543 respondents. One question in the survey was what transportation mode was used to get to/from this development. The mode shares from the intercept survey are presented in Table 5.5. We then applied these mode shares to the total trip-generation counts by entrance to compute the final weighted mode shares.

The final mode shares for Englewood TOD are 19.2 percent walk, 3.8 percent bike, 3.3 percent bus, 13.6 percent rail, and 59.7 percent auto (Table 5.5). According to the 2009 Denver Regional Council of Governments' household travel survey, the regional mode shares are 5.7 percent walk, 0.9 percent bike, 2.1 percent bus, 0.8 percent rail, and 88.3 percent auto. Compared to the regional mode shares, Englewood TOD has a significant mode shift from automobiles to walking and transit. Englewood TOD 
has 3.4 times the percentage of walk trips as the regional average, 1.6 times the percentage of bus trips, and 17 times the percentage of rail trips.

Table 5.5. Mode Shares in Englewood TOD

\begin{tabular}{|c|c|c|c|c|c|c|c|}
\hline \multicolumn{8}{|c|}{ Intercept survey } \\
\hline \multirow[b]{2}{*}{ Entrance } & Count & \multicolumn{6}{|c|}{ Mode share (\%) } \\
\hline & & Walk & Bike & Bus & Rail & Auto & Other \\
\hline West Block & 183 & 15.3 & 3.8 & 6.0 & 9.3 & 65.0 & 0.5 \\
\hline Southeast Block & 127 & 24.4 & 3.1 & 0.0 & 12.6 & 59.8 & 0.0 \\
\hline Northeast Block & 220 & 19.5 & 5.0 & 2.7 & 24.5 & 48.2 & 0.0 \\
\hline \multicolumn{8}{|c|}{ Trip generation counts } \\
\hline \multirow[b]{2}{*}{ Entrance } & Count & \multicolumn{6}{|c|}{ Count for modes } \\
\hline & & Walk & Bike & Bus & Rail & Auto & Other \\
\hline West Block & 6,398 & 979 & 245 & 385 & 594 & 4,160 & 35 \\
\hline Southeast Block & 4,704 & 1,148 & 148 & 0 & 593 & 2,815 & 0 \\
\hline Northeast Block & 2,971 & 581 & 149 & 81 & 729 & 1,431 & 0 \\
\hline Final mode shares & 14,073 & $19.2 \%$ & $3.8 \%$ & $3.3 \%$ & $13.6 \%$ & $59.7 \%$ & $0.2 \%$ \\
\hline
\end{tabular}

\section{Trip Generation}

Our actual trip generation counts from the survey did not distinguish residential trips and commercial trips. To compare the actual trip generation with ITE's benchmarks, we combine all estimated trips for different uses into a total that can be compared to ITE.

There were 14,073 person trips and 9,460 vehicle trips observed the day of the survey. Those trips were generated by 430 occupied residential units $(438 * 0.982)$ and 309,546 square feet of leased commercial space.

To calculate a trip-generation rate for the residential building at Englewood TOD, we used the ITE Trip Generation Manual value for "223 Mid-Rise Apartment," which is defined as "apartments (rental dwelling units) in rental buildings that have between three and 10 levels (floors)." The ITE manual reports a trip-generation rate for the peak hour but does not report a daily trip-generation rate for mid-rise apartments. However, the ITE manual does report a daily trip-generation rate for all apartments ("220 Apartments"). We used this rate to compute the daily trip-generation rate for mid-rise apartments. Here was the process: (1) the average daily vehicle trip-generation rate for "220 Apartments" is 6.65 per dwelling unit on a weekday, 0.55 per dwelling unit at the AM peak hour on a weekday, and 0.67 per dwelling unit at the PM peak hour on a weekday; (2) the average vehicle trip-generation rate for "223 Mid-Rise Apartment" is 0.35 per dwelling unit at the AM peak hour on a weekday and 0.44 per dwelling unit at the PM peak hour on a weekday; and (3) the average daily vehicle trip-generation rate for " 223 Mid-Rise Apartment" therefore equals $6.65^{*}(0.35+0.44) /(0.55+0.67)$, which is 4.31 per dwelling unit.

For the commercial uses at the Englewood TOD, we calculated a trip-generation rate using the ITE Trip Generation Manual values for "590 Library" for the Englewood Public Library and "733 Government Office Complex" for the government administration offices in the civic center. 
We were forced to choose an analog for the trip-generation rate of the museum at Englewood TOD. The ITE manual has a category "580 Museum," but it does not provide an average daily vehicle tripgeneration rate. The manual reports the average vehicle trip-generation rate for the AM peak hour on a weekday, which is 0.35 per 1,000 square feet GFA. "590 Library" is the closest analog to museum in the ITE manual. For 590, the daily average vehicle trip-generation rate on a weekday is 56.24 per 1,000 square feet GFA and the average vehicle trip-generation rate for the AM peak hour on a weekday is 4.47 per 1,000 square feet Therefore, the average daily vehicle trip-generation rate for " 580 Museum" equals $56.24 *(0.35 / 4.47)$, which is 4.40 per 1,000 square feet This is very similar to what we would get if we assumed a daily trip-generation rate 10 times the AM peak hour trip-generation rate, the common default value.

We considered all other commercial uses a shopping center and used "820 Shopping Center" for its tripgeneration rate. We treated the other commercial uses as a shopping center because there are so many lessees, some occupying very little space, and many without appropriate ITE land use categories. Also the ratio of retail space to residential units is much greater for Englewood than other TODs studied, except for Fruitvale.

Based on ITE's trip-generation rates, the Englewood TOD would be expected to generate 13,544 daily vehicle trips (Table 5.6). The number of actual vehicle trips we observed on the survey day was 9,460, just 68.4 percent of the ITE expected value. This is the highest percentage of the ITE value found in any of the TODs included in this study ${ }^{7}$. Englewood TOD has an abundance of free surface and structured parking, and the Denver transit system is less fully developed than those of the other regions studied. Also, with only two stories of apartments (plus ground-floor retail), the TOD does not achieve a density that would have increased transit mode share and made retail more successful.

Table 5.6. The Comparison of Daily Vehicle Trip Generation between ITE Guideline and Englewood TOD

\begin{tabular}{|c|c|c|c|}
\hline & Trip generation rate & Total units & Total daily trips \\
\hline ITE guideline & - & - & 13,544 \\
\hline 223 Mid-Rise Apartment & 4.31 & 430 & 1,853 \\
\hline 580 Museum & 4.40 & 14,855 & 65 \\
\hline 590 Library & 56.24 & 31,000 & 1,743 \\
\hline 733 Government Office Complex & 27.92 & 93,145 & 2,601 \\
\hline 820 Shopping Center & 42.70 & 170,546 & 7,282 \\
\hline Englewood TOD & - & - & 9,460 \\
\hline
\end{tabular}

\section{Parking Generation}

7

\begin{tabular}{|l|r|r|r|}
\hline Regions & Road Density & \multicolumn{1}{|c|}{ Transit Frequency } & Vehicle Mile per capita \\
\hline Denver & 5.79 & 8,924 & 23.87 \\
\hline Los Angeles & 6.11 & 13,866 & 20.37 \\
\hline San Francisco & 7.78 & 13,901 & 38.20 \\
\hline Seattle & 4.86 & 12,693 & 34.75 \\
\hline Washington, D.C. & 7.90 & 7,926 & 38.91 \\
\hline
\end{tabular}


Parking supply and demand recorded for the Englewood TOD project are compared to the number of parking stalls as well as occupancy rates from the 2010 ITE Parking Generation manual.

\section{Residential}

To get parking generation rates for the residential component of the TOD, we consult the ITE Parking Generation Manual's, "221 Low/Mid-Rise Apartment," defined as rental dwelling units located in buildings up to four stories (floors) in height. This is the best match for the three-story multifamily residential uses at the Englewood TOD. The average parking-supply ratio reported by ITE is 1.4 parking spaces per dwelling unit at both urban and suburban sites (derived from 68 study sites).

For the ITE land use category 221: Low/Mid-Rise Apartment (urban location), the average peak period parking demand from 40 study sites is 1.20 vehicles per dwelling unit, with a standard deviation of 0.42 , a range of $0.66-2.50$, an $85^{\text {th }}$ percentile value of 1.61 , and a $33^{\text {rd }}$ percentile value of 0.93 . Besides the average rate, the ITE manual also provides the best-fitting regression line for estimating total parked vehicles as a function of the total number of dwelling units:

$$
\mathrm{P}=0.92 \mathrm{x}+4
$$

Where $\mathrm{P}=$ parked vehicles and $\mathrm{x}=$ dwelling units

There are two apartment complexes at Englewood TOD: 801 Apartment Complex with 211 units (208 units occupied) and 901 Apartment Complex with 227 units (222 units occupied). Each of them has its own parking garage or lot. The West Block North Parking Structure is designated for the 901 Apartment Complex and the employees of retail and office. We are not sure how many spaces are designated for retail and office employees, but we were told it is a small number. Therefore, we consider all of them to be residential parking. On-street parking along South Inca Street is between the two apartment complexes and open to public, but we were told the primary users are residents. We observed that the peak parking demand in this parking area was at midnight on the survey day, which supports the idea that it is used mainly by residents. So we consider this parking area to be residential parking, too. Englewood Parkway's on-street parking spaces are shared between residential and commercial users. We do not know how many spaces are designated for residential uses. Therefore, we exclude this parking area for the parking supply analysis. We include the number of vehicles parked in this area at midnight on the survey day for the peak parking demand analysis because, presumably, only residential parkers (no commercial parkers) used it at this hour.

As shown in Table 5.7, the actual parking supply for the residential units at Englewood TOD is 700 spaces, or 1.60 parking spaces per unit $((304+354+42) /(211+227))$. This is slightly more than ITE's guideline of 1.4 spaces per unit.

The peak occupancy of parking spaces in all the residential parking areas was at midnight. At that hour, there were spaces filled at the 801 Apartment Complex parking lot, for an occupancy rate of 91 percent, 222 spaces filled at the 901 Apartment Complex parking garage, for an occupancy rate of 63 percent, 38 spaces filled at the South Inca Street on-street parking area, and 19 spaces filled in the shared portion of the Englewood Parkway on-street parking area. Thus, the peak parking demand for the residential portion of Englewood TOD relative to occupied units is 556 spaces, or 1.29 spaces/occupied unit 
$((277+222+38+19) /(208+222))$. At Englewood TOD, actual demand (556 spaces) is higher than both the ITE estimate of $516(1.20 * 430$, occupied units only), based on the average parking-generation rate, and the ITE estimate of $400(0.92 * 430+4$, occupied units only), based on the regression equation.

\section{Commercial}

There is a total of 332,884 square feet of leasable space for commercial uses at the Englewood TOD, 309,546 square feet of which were leased at the time of this study. There are three parking areas that are available to commercial users: West Block (WB) South Parking Structure, Southeast Block (SEB) Surface Parking, and Englewood Parkway (EP) on-street parking. RTD users have access to 315 spaces in the West Block (WB) South Parking Structure. We do not have separate parking demand data for RID transit users and commercial users. However, because transit users' parking demand of is similar to commercial users' parking demand - high demand during the day and low demand during the night - we assume that the peak parking demand of transit users is in the same proportion as the parking supply for transit users. We estimate the peak parking demand for commercial users by subtracting transit users' peak parking demand from the total peak demand in the WB South Parking Structure. Part of Englewood Parkway's on-street parking is shared by commercial and residential users. We do not have separate parking supply and demand data for this area, either. But we do know the peak parking demand during the day on the survey day; therefore, we treat everyone parked in this area during the daytime peak hour as commercial users.

Table 5.7 lists commercial uses parking supply and peak parking demands for the closest analogs in the ITE Parking Generation manual. These uses are 580: Museum (Museum of Outdoor Arts \& Hampden Hal), 590: Library (Englewood Public Library), 730: Government Office Building (the government administration offices in the Civic Center), and 820: Shopping Center (all the other commercial uses at Englewood TOD).

According to the ITE manual, the parking supply for these commercial uses should be 1,296 spaces $(3 * 14.855+3.5 * 31+3.3 * 93.145+4.9 * 170.546)$. The actual parking supply at the Englewood TOD is 853 spaces for all commercial uses. We cannot know precisely the actual parking supply just for the leased commercial space, but it would be about 93 percent of the total spaces based on the percentage of total floor area currently leased. This is to say, based on the current leases, about 793 spaces might be associated with currently leased commercial space. This is 61 percent of the ITE parking supply guideline (as shown in Table 3.7).

According to the ITE guidelines, the average total peak period parking demand for Englewood TOD's leased commercial spaces would be 917 spaces $(0.98 * 14.855+2.61 * 31+4.15 * 93.145+2.55 * 170.546)$. The actual peak parking demand of the commercial uses at the Englewood TOD was 589 occupied spaces on the survey day, which is 64 percent of the ITE peak parking demand estimate.

Table 5.7. Comparison of Parking Supply and Demand between Englewood TOD and ITE Guidelines

\begin{tabular}{|l|c|c|}
\hline \multicolumn{3}{|c|}{ Residential } \\
\hline & Supply & Peak period demand \\
\hline
\end{tabular}




\begin{tabular}{|c|c|c|c|c|}
\hline & $\begin{array}{l}\text { Parking spaces } \\
\text { per unit }\end{array}$ & $\begin{array}{l}\text { Total parking } \\
\text { spaces }\end{array}$ & $\begin{array}{l}\text { Vehicles per } \\
\text { unit }\end{array}$ & $\begin{array}{l}\text { Total parked } \\
\text { vehicles }\end{array}$ \\
\hline $\begin{array}{l}\text { ITE guideline: } 221 \\
\text { Low/Mid-Rise Apartment }\end{array}$ & 1.4 & 602 & 1.20 & 458 \\
\hline $\begin{array}{l}\text { Englewood TOD: } 801 \text { and } \\
901 \text { Apartment Complexes }\end{array}$ & 1.60 & 700 & 1.29 & 556 \\
\hline \multicolumn{5}{|c|}{ Commercial (occupied space only) } \\
\hline & \multicolumn{2}{|c|}{ Supply } & \multicolumn{2}{|c|}{ Peak period demand } \\
\hline & $\begin{array}{l}\text { Parking spaces } \\
\text { per } 1,000 \text { sq. ft. } \\
\text { GFA }\end{array}$ & $\begin{array}{l}\text { Total parking } \\
\text { spaces }\end{array}$ & $\begin{array}{l}\text { Vehicles per } \\
\text { unit or } 1,000 \\
\text { sq. ft. GFA }\end{array}$ & $\begin{array}{l}\text { Total parked } \\
\text { vehicles }\end{array}$ \\
\hline ITE guideline & - & 1,296 & - & 917 \\
\hline 580 Museum & 3.0 & 45 & 0.98 & 15 \\
\hline 590 Library & 3.5 & 109 & 2.61 & 81 \\
\hline $\begin{array}{l}730 \text { Government Office } \\
\text { Building }\end{array}$ & 3.3 & 307 & 4.15 & 387 \\
\hline 820 Shopping Center* & 4.9 & 836 & 2.55 & 435 \\
\hline Englewood TOD & - & 793 & - & 589 \\
\hline \multicolumn{5}{|c|}{ Total } \\
\hline & \multicolumn{2}{|c|}{ Supply } & \multicolumn{2}{|c|}{ Peak period demand } \\
\hline ITE guideline & & 1,898 & & NA** \\
\hline Englewood TOD & & 1,493 & & $870^{* * *}$ \\
\hline
\end{tabular}

*Parking supply ratio for community shopping center is used. Average peak period parking demand on a non-Friday weekday (non-December) is used.

**The peak parking demand of residential and the peak parking demand of commercial are different periods during a day. We cannot simply sum them to get a total peak parking demand.

***The most parked vehicles at the TOD for any one hour on the survey day.

In sum, the overall parking supply for the residential and occupied commercial space at Englewood TOD should be 1,898 spaces, according to the ITE guideline. The overall actual parking supply for the residential and occupied commercial space is 1,493 spaces, just 79 percent of the ITE guideline. The actual peak period parking demand of the residential and commercial uses at Englewood TOD was 870 occupied spaces for the one hour of the survey day with most parked cars. This is only 46 percent of the ITE supply guidelines and 58 percent of the Englewood TOD's actual supply. We provide these last estimates to suggest what would be theoretically possible with shared residential and commercial parking.

\section{Parking Demands for Different Land Uses}

At the Englewood TOD, there are seven parking lots and structures. We categorized them into three different uses: RTD park-and-ride, residential parking, and commercial (retail and office) parking. The West Block North Parking Structure is designated for the residents of 901 Apartment Complex and the employees of its retail and office uses. We are not sure how many spaces are filled by the retail and office employees, but we were told that it is a small number. Therefore, we considered all of them to be residential parking. For the West Block South Parking Structure, we assume that the parking demand of RTD transit users and commercial users falls in the same proportion as their parking supply. We exclude on-street parking along Englewood Parkway from this analysis because it is shared between residential and commercial users and we do not have data showing demand from each group. Parking demand from 
the RTD transit users and from residential and commercial users during the survey day are shown in Figure 5.11 Demand for RTD park-and-ride was high at midday. About 90 percent of the parking spaces were occupied from 9:00 a.m. to 2:00 p.m. Demands dropped quickly, reaching a low of less than 10 percent occupancy after 8:00 p.m.

Demand for residential parking was low at midday. Just 40 percent of the residential parking spaces were occupied from 8:00 a.m. to 2:00 p.m. Demand started to increase after 2:00 p.m. and peaked at midnight. The peak occupancy rate was 77 percent.

Demand for commercial parking was highest at midday but still far short of capacity. About 60 percent of the parking spaces were occupied from 10:00 a.m. to 2:00 p.m. Demand dropped to less than 20 percent occupancy after 8:00 p.m. From the standpoint of commercial parking, Englewood TOD is over-parked. There would clearly be benefits to having more parking shared among uses.

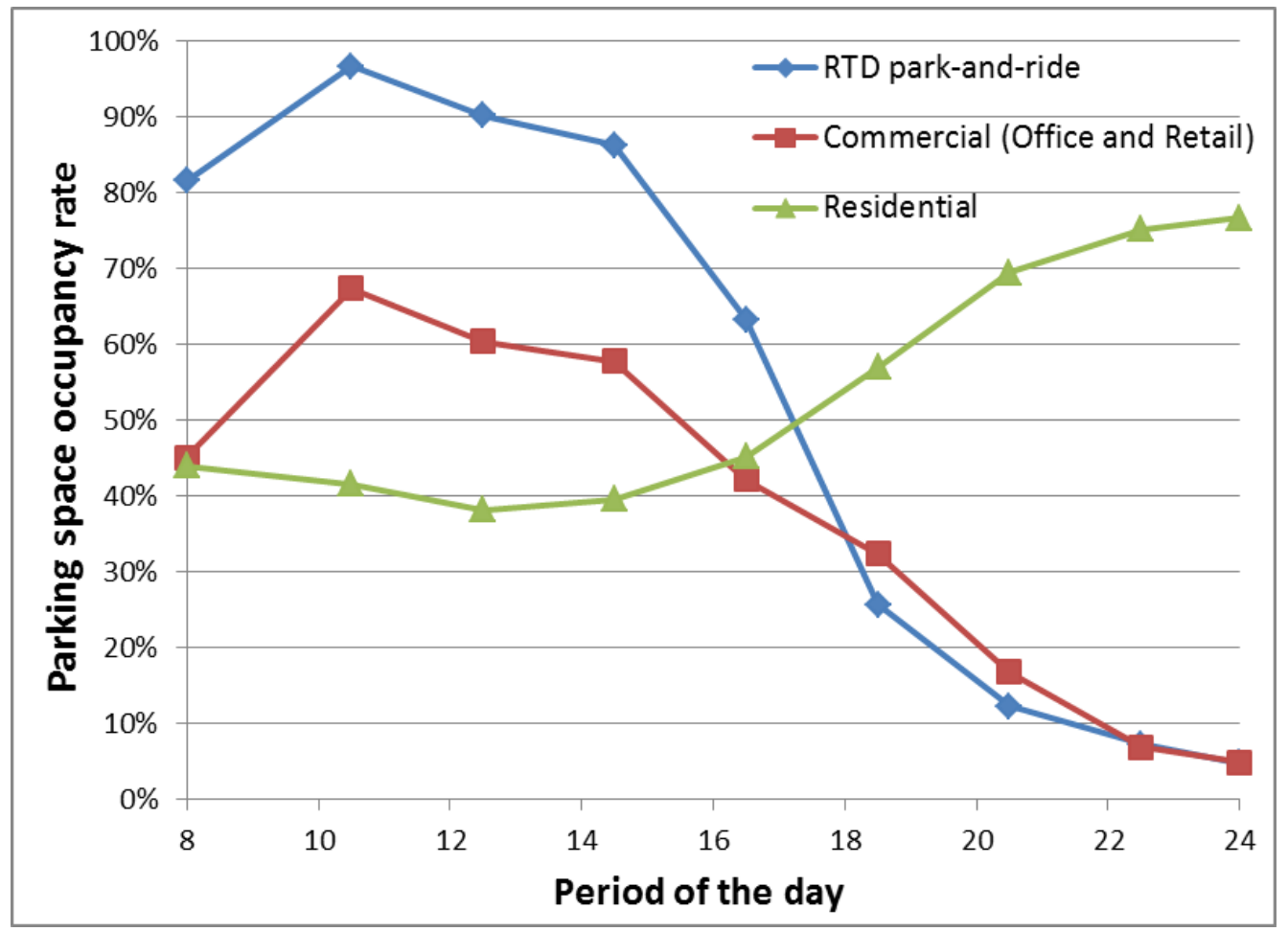

Figure 5.11. Parking Space Occupancy Rate for Different Uses at Englewood TOD

\section{Discussion}

The Englewood TOD site is unique compared to the other TODs studied, as it is the only one that replaced an enclosed regional mall with a mixed-use TOD. Englewood city staff use the term "hybrid" to describe their TOD. The need for sales tax revenue drove the design of CityCenter Englewood and led the city to include big-box retail in the design. Zone 1, the western-most zone, is the only portion of the project that can be really called transit-oriented. Zone 2, the big-box portion, is occupied by a Wal-Mart with the typical sea of parking in front. This same quest for sales tax revenue, and the availability of principal arterial frontage along the southern boundary of the project, caused this portion of the project 
(Zone 3) to be highway oriented as well. Only Zone 2 was excluded from our counts and the intercept survey.

The inclusion of big-box retailers dilutes the benefits of TOD with respect to Zone 1. Wal-Mart insisted (as a condition of locating there) that the residential development be parked at 1.5 spaces per dwelling unit, rather than the 1 space per dwelling unit that the city favored. Wal-Mart did not want parking from the apartment complex spilling into the Wal-Mart parking lot. To some degree, which Don Shoup and others have discussed, the oversupply of parking creates its own demand. Unlike some of the TODs studied, the abundance of free parking at Englewood has led to peak parking rates for residential development similar to ITE's.

With respect to parking, Englewood TOD is an interesting anomaly. While generally over-parked, the ground floor retail on the western most portion of the site has remained mostly vacant for lack of adequate parking. From on-site observations by the principal investigator of this project, there just does not appear to be enough transit traffic to make these spaces viable commercially. Yet, the only parking available to would-be patrons of shops in these locations is on-street parallel parking in the roundabout. The parking garage at northwestern edge of the project is not shared, but rather is restricted to residential users. This is in contrast to Rhode Island Row and Fruitvale, for example, where commercial patrons can park in the same garage with residential users. The development is saved, in a sense, by the civic center on the southwestern side of the roundabout, which is a lively place with the nearby library, courts, museum, and city offices. But even the civic center doesn't generate a lot of street activity because its parking garage is behind the building.

Although the reductions in trip and parking generation are not as large at Englewood as the other TODs studied, the Englewood case study is still instructive. First, it shows that even a relatively auto-oriented TOD can achieve walking and transit mode shares better than regional the average and reduce both trip and parking generation relative to ITE rates. The Englewood TOD generates vehicle trips at 68 percent of ITE rates and generates peak parking demands for the commercial uses at 64 percent of ITE rates.

Second, this case study shows that TODs may not achieve their full potential if designed for the automobile in a hybrid configuration like Englewood's. The need for sales tax revenue from CityCenter Englewood comes at a cost in transportation terms. Users of this report can estimate the cost by comparing the mode shares in this case study to the others, and by comparing the trip and parking reductions in this case study to the others.

Finally, this case study shows that the failure to create shared parking across the development is a lost opportunity. None of our case studies provides shared parking to the extent they might, but Englewood only has shared parking in the civic center parking garage (and on-street). The fact that commercial uses do not share parking with residential uses on the western end of the site is particularly unfortunate. To some degree, the better performance (higher lease rates) of commercial uses on the eastern side of the TOD may, ironically, be due to greater auto orientation. Angle parking along this section of Englewood Parkway provides more parking for commercial patrons, and this section of Englewood Parkway is more easily accessed from US-285 via South Inca Street. 


\section{Chapter 6: Wilshire/Vermont TOD, Los Angeles Region}

The Wilshire/Vermont TOD is located in Los Angeles' Koreatown neighborhood, approximately three miles west of downtown. It sits on the northeast corner of Wilshire Boulevard and Vermont Avenue above a Los Angeles County Metropolitan Transportation Authority (Metro) subway station and adjacent to two of the region's busiest bus corridors. The area is also part of the Wilshire Center commercial district, which stretches from downtown along Wilshire Boulevard toward the west-side suburbs of Century City, Beverly Hills, and Santa Monica. The setting is arguably the most urban of those studied, and at 140 dwelling units per net and gross acre, the TOD is undeniably the densest of those studied.

The area has gone through several cycles of redevelopment throughout its history. Development spread west from downtown Los Angeles along Wilshire Boulevard in the early 20th century, and the district quickly became a playground for the Hollywood elite. In the 1930s, the now-demolished Ambassador Hotel hosted some of the first Academy Awards ceremonies, and the neighborhood still is home to the largest concentration of art-deco buildings in the city. However, the area's economic fortunes had declined by the late 1960s, and Korean immigrants attracted by low rents and a welcoming atmosphere began moving into the area and opening businesses.

Today, Koreatown is one of the most densely populated and ethnically diverse neighborhoods in the city. More than 120,000 people live in Koreatown's 2.7 square miles, giving it an average population density of more than 42,000 people per square mile, according to the Los Angeles Times' Mapping L.A. project. Despite the neighborhood's name and history as an ethnic Korean enclave, more than half the current residents are Latino, about one third are Asian, and the rest are a mix of white, black, and other ethnic groups. The area remains a magnet for immigrants, though. More than two-thirds of Koreatown residents were born outside the U.S., one of the highest proportions in the city. The median income is among the lowest in the city, while the proportion of single residents is higher than average. 


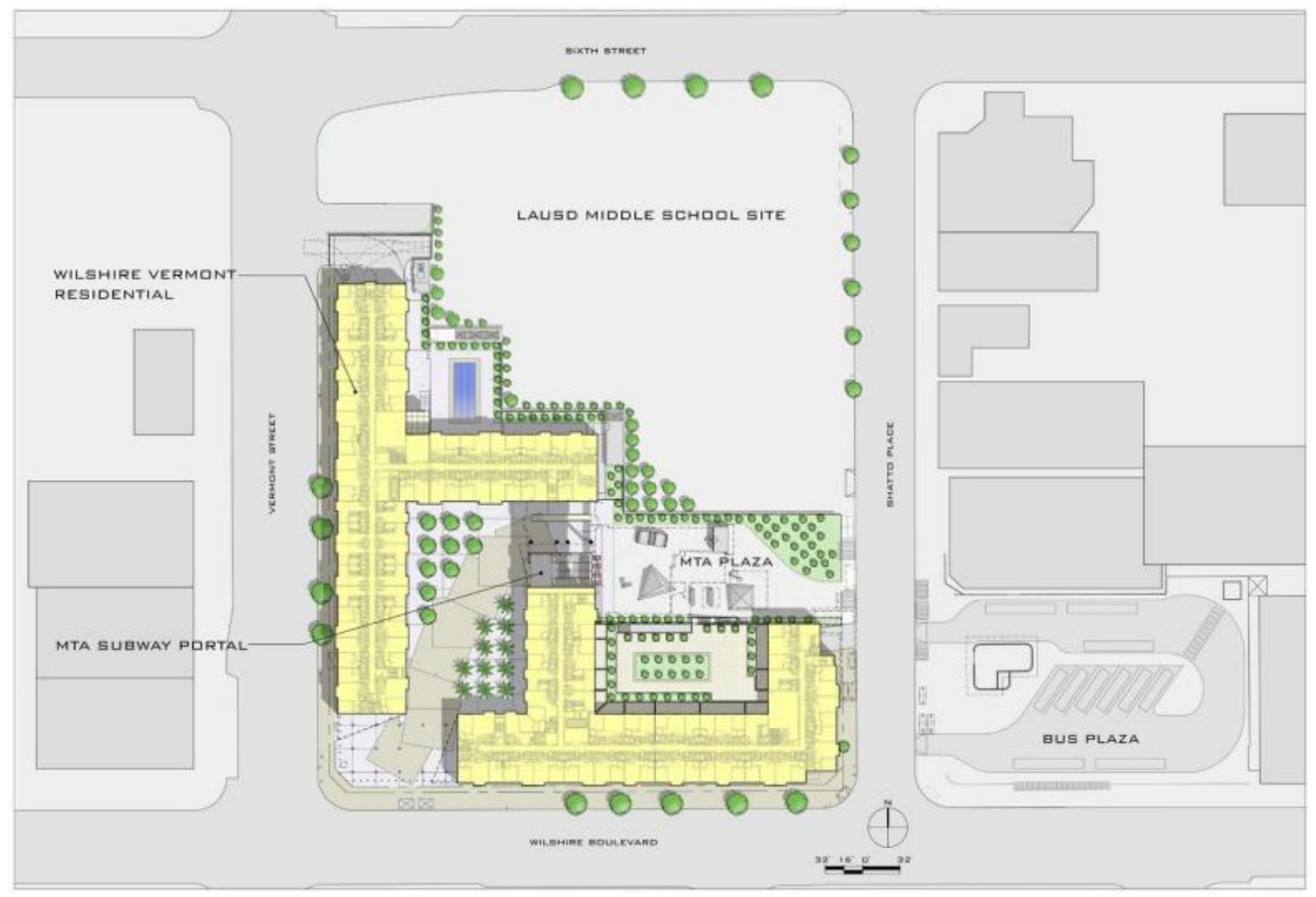

Figure 6.1. Wilshire/Vermont TOD Site Plan

\section{History}

The TOD occupies almost an entire city block that formerly housed an office building, a Metro bus plaza, and a subway portal. Interest in redevelopment started in the late 1990s with the construction of Metro's Red Line, a heavy-rail subway that connects downtown to North Hollywood. Metro also planned to redistribute bus stops to surrounding streets after opening Wilshire-Vermont Station in 1999. These reconfigurations meant that the land at ground level was no longer needed for transit purposes, making it eligible for Metro's Joint Development Program (JDP), which redevelops Metro-owned real estate by leasing it out for commercial uses.

Metro does not develop all JDP properties as TODs. In fact, Wilshire-Vermont Station is only the second - the first was at Hollywood and Highland. But the agency recognized from the beginning that the block had a lot going for it from both residential and retail perspectives.

First, the Federal Transit Administration encourages TOD near its projects, and it had provided funding for the Red and Purple Lines, so Metro was leaning toward TOD already.

Second, the station's location in an ethnically diverse neighborhood with a high demand for housing meant that the developer could draw potential residents and retail customers from multiple populations. This made the area more attractive for private investment. 
Finally, the Community Redevelopment Agency of the City of Los Angeles (CRA/LA) had designated large sections of Koreatown and the Wilshire Center commercial district as a redevelopment area in 1995. The designation authorized the use of tax-increment financing (TIF) to make physical improvements to the neighborhood. CRA/LA did not fund the TOD project directly, but it did make the area more attractive in general for both residents and developers.

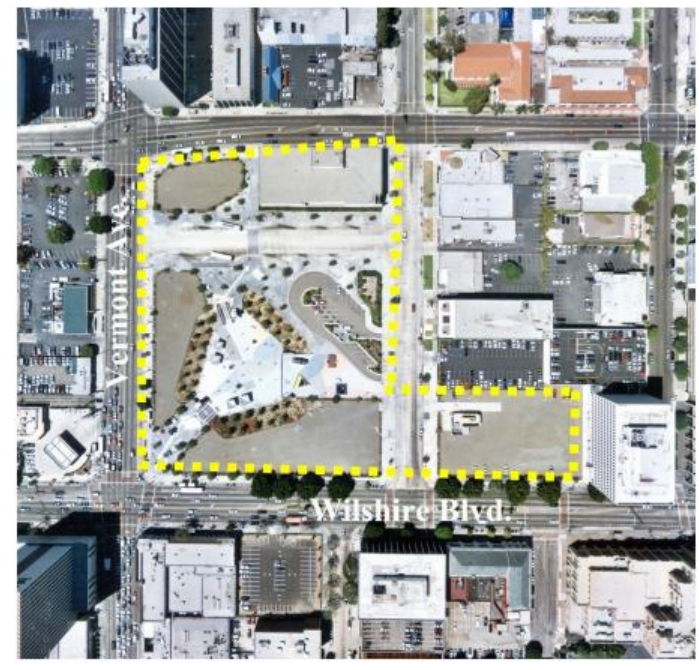

(a) Before the Project

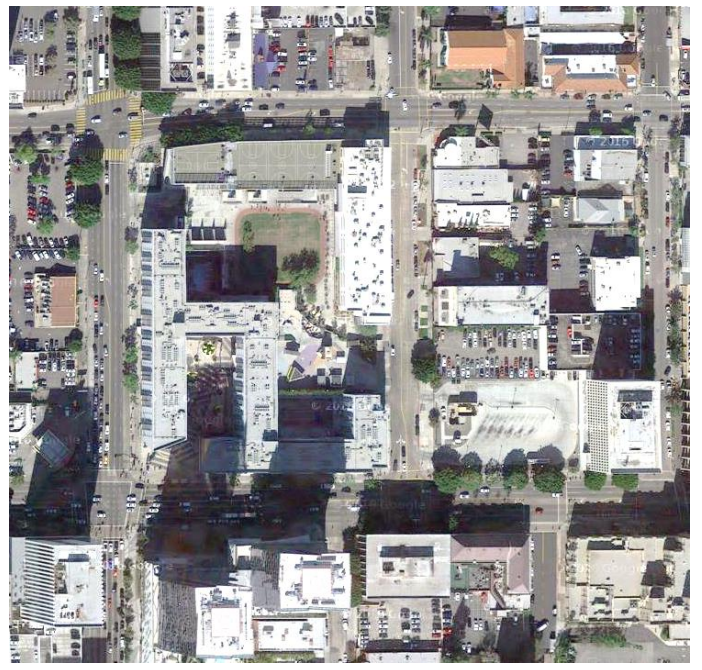

(b) After the Project

Figure 6.2. Wilshire/Vermont TOD: (a) Before the TOD Project; (b) After the TOD Project

\section{Transit Connection}

Wilshire/Vermont is one of the city's premier transit corners. The area is served by two subway lines and a number of bus lines. The heavy-rail subway lines - Metro's Red Line and Purple Line - both connect to Union Station in downtown Los Angeles via tracks running underneath Wilshire Boulevard. The tracks diverge at Wilshire/Vermont Station, with the Red Line heading north to terminate at North Hollywood Station and the Purple Line continuing west to the Wilshire/Western Station.

Wilshire Boulevard and Vermont Avenue are also two of the busiest bus corridors in the city. Local buses, as well as express Metro Rapid, DASH, and Foothill Transit buses all serve Wilshire/Vermont Station, with nearly 10,000 passenger boardings and 10,000 alightings per day. A bus plaza and transfer station provides connections one block to the east. 


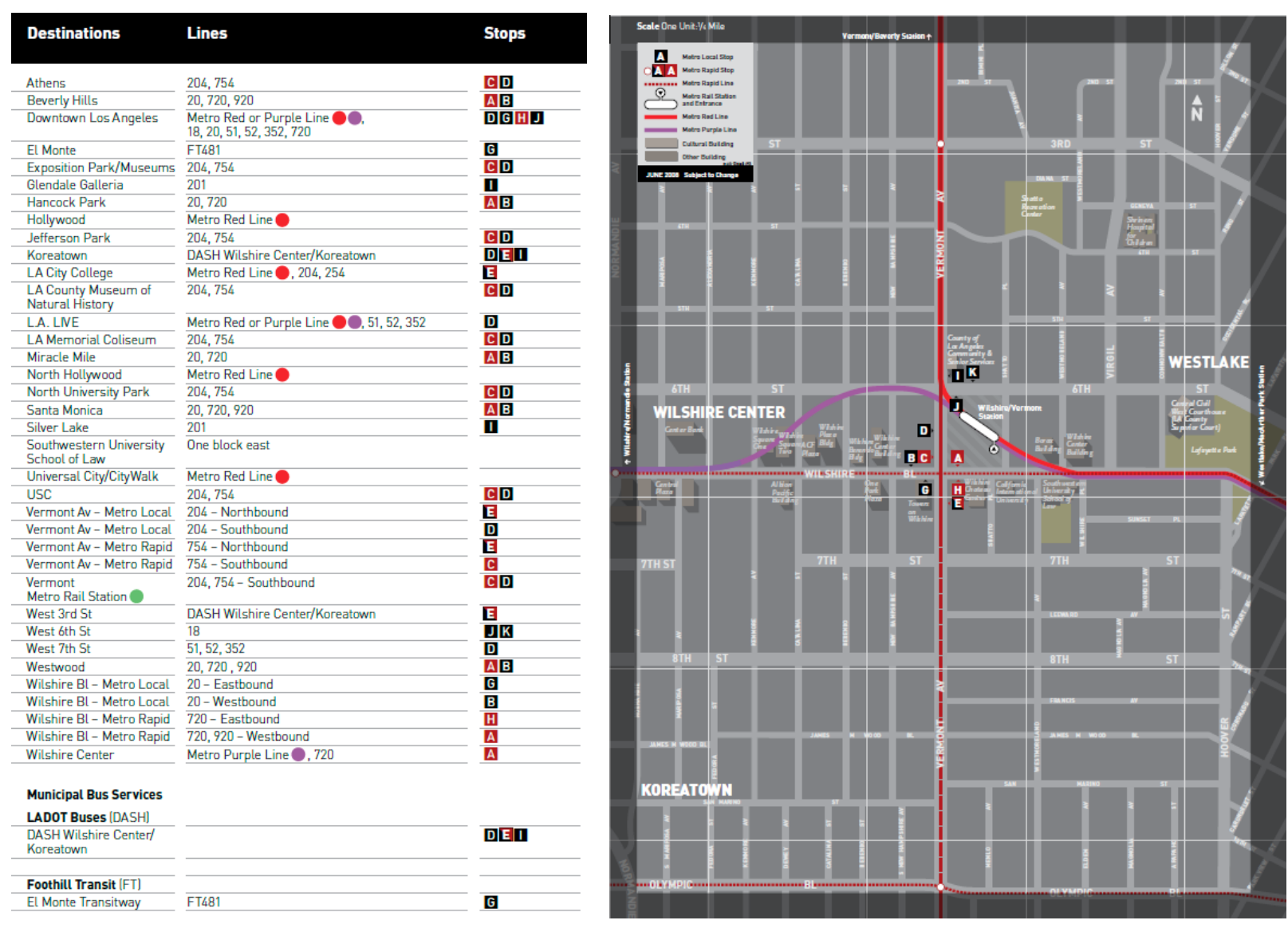

\section{Figure 6.3. Transit Connections at Wilshire/Vermont Station}

Metro's main concern when constructing the subway lines in the late 1990s was capitalizing on the neighborhood's high transit demand. Initial designs for the rail station featured two underground levels, one for the main transit plaza and one for the train platforms, with retail at ground level on a few scattered parcels. This design not only restricted retail development to a handful of ground-level pads with limited parking, but handicapped access to the platforms was difficult because it required multiple elevator rides.

Redesigning the project to accommodate residential and retail development also led to a redesign of the station itself. The developers, Mack Urban (formerly MacFarlane Partners) and Urban Partners LLC, came up with the idea of raising the transit plaza to ground level and surrounding it with buildings to free up space underground for two levels of parking and a single level for the subway platforms. The redesign also improved access to the station for all users by opening up more entrances and simplifying navigation.

\section{The Development Itself}

The mixed-use Wilshire Vermont Station Apartments consist of two connected seven-story residential buildings with ground floor retail surrounding a pedestrian plaza. Parking is underground in a two-floor garage. The building has 449 apartments and 36,500 square feet of retail space. Apartments range from 500 -square-foot studios to 1,060-square-foot two-bedroom units. At 140 units per acre, this TOD is the densest of those studied. 
Twenty percent of the residential units are set aside for low-income residents, who are defined as people making 50 percent or less of the area's median income. The affordable-housing component was a requirement of an interest-free loan provided by the State of California to the developers.

The residential portion of the development is currently at 97 percent occupancy. Seventeen of the nineteen retail units are leased. Both residential and retail portions of the TOD leased out quickly when it opened. "That's not always the case with all our projects," said Greg Angelo, director, countywide planning and development - real estate, for Metro. More typically, "the housing leases quickly, the retail, not so much." However, retail spaces at Wilshire Vermont Station Apartments have commanded strong rents since the development opened in 2007.

Table 6.2. Commercial Uses in Wilshire/Vermont TOD

\begin{tabular}{|l|r|}
\hline Land uses & Unit (sq. ft.) \\
\hline Ila Optometry & 1,371 \\
\hline The Coffee Bean \& Tea Leaf & 1,625 \\
\hline Palace Beauty & 1,498 \\
\hline Onails & 1,395 \\
\hline Metro Fresh & 1,699 \\
\hline MTA Outpost & 2,397 \\
\hline Yogurt land & 1,269 \\
\hline Dr Midas Medical Clinic & 1,491 \\
\hline Gamestop & 1,476 \\
\hline T-Mobile & 2,149 \\
\hline Subway & 1,200 \\
\hline Wasabi Japanese Noodle House & 1,858 \\
\hline Chipotle Mexican Grill & 2,357 \\
\hline UPS & 1,025 \\
\hline Shiloh & 1,150 \\
\hline Chase Bank & 4,059 \\
\hline
\end{tabular}

A new middle school opened in 2009 adjacent to the apartments on the northeast corner of the block. Young Oak Kim Academy focuses on science, technology, engineering and mathematics (STEM), and is the only middle school in the Los Angeles United School District (LAUSD) to educate boys and girls in single-sex classrooms. Metro originally planned for the school to be developed alongside the mixed-use building next to it, but repackaged the deal after learning that LAUSD could not get construction financing with just a ground lease. The agency sold the land to LAUSD, which developed that portion of the block separately.

The building's design has been generally well received. A hand-painted, 8,200 square foot mural, Hand Holding a Bowl of Rice, by artist April Greiman, provides visual character from Wilshire Boulevard and has become a local landmark. But the pedestrian plaza itself was not initially successful. A 2007 review by the Los Angeles Times criticized the lack of shade and character in the plaza. A subsequent redesign softened the space and added color with palm trees and other vegetation in brightly colored planters. 
There is no official transit parking located on-site. However, if a transit user wanted to park in the retail/residential visitors area, they could. That being said, the parking officials there said they see very little (if any) transit parking usage.

The one-bedroom and studio apartments get one parking space with their rental agreement. The twobedroom apartments get two parking spaces. There is no extra charge for parking - it is bundled into the rental price already. If a resident does not have a vehicle, there is no cost savings for not using the associated parking space. This is another example where unbundled parking would probably lead to lower parking occupancy and greater economic efficiency by sending the right market signals to apartment dwellers.

Table 6.1. Development Summary of Wilshire/Vermont TOD Project (this is a heavy rail served TOD and there is no park-and-ride)

\begin{tabular}{|l|l|l|l|}
\hline Land uses & Description & Unit & \multicolumn{1}{|c|}{ Occupancy* } \\
\hline Commercial & Ground floor & 37,021 square feet (sq. ft.) & $\begin{array}{l}75.7 \% \text { (28,019 sq. } \\
\text { ft.) }\end{array}$ \\
\hline Residential & $\begin{array}{l}\text { 6 stories above } \\
\text { commercial }\end{array}$ & $\begin{array}{l}449 \text { units (90 units are } \\
\text { affordable) }\end{array}$ & $96.2 \%$ (432 units) \\
\hline Parking & Description & Unit & Occupancy** \\
\hline $\begin{array}{l}\text { Wilshire-Vermont } \\
\text { Garage: public }\end{array}$ & $\begin{array}{l}\text { Level 1 of a 3-level } \\
\text { parking garage. Open } \\
\text { to retail and } \\
\text { residential visitors }\end{array}$ & 71 stalls & $107 \% * * *$ \\
\hline $\begin{array}{l}\text { Wilshire-Vermont } \\
\text { Garage: residential**** }\end{array}$ & $\begin{array}{l}\text { Level 1 to 3 of a 3- } \\
\text { level parking garage. } \\
\text { Only open to } \\
\text { residents }\end{array}$ & 495 stalls & $70.5 \%$ \\
\hline
\end{tabular}

*On November 17, 2015.

**The peak occupancy at November 17, 2015.

***This is more than 100 percent because businesses offer valet parking (i.e. double park, tandem park, etc.) during peak times.

****A portion of the visitor stalls are currently reserved for residents, while about 100 additional residential stalls are under construction.

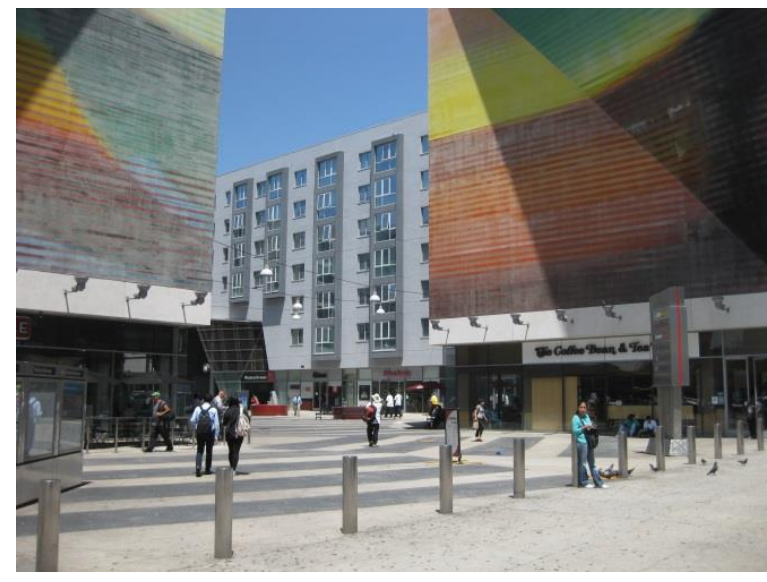

(a) Entrance to the TOD

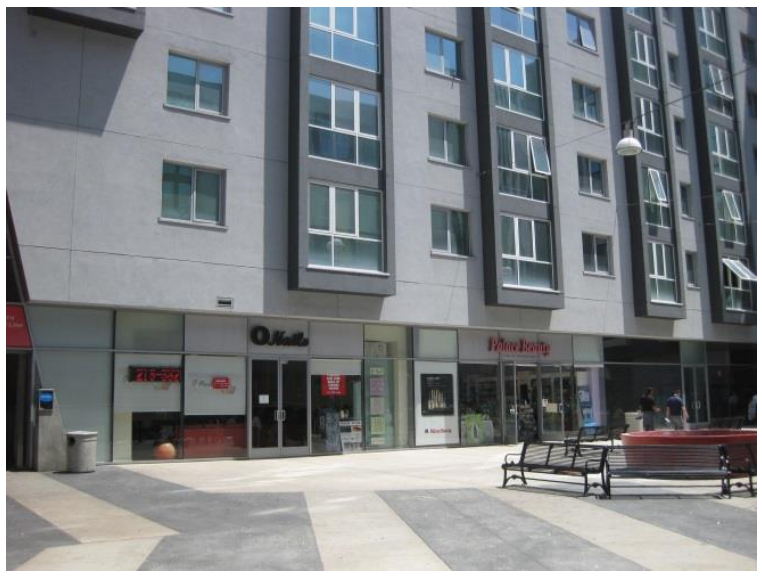

(b) Apartments with ground floor retail 


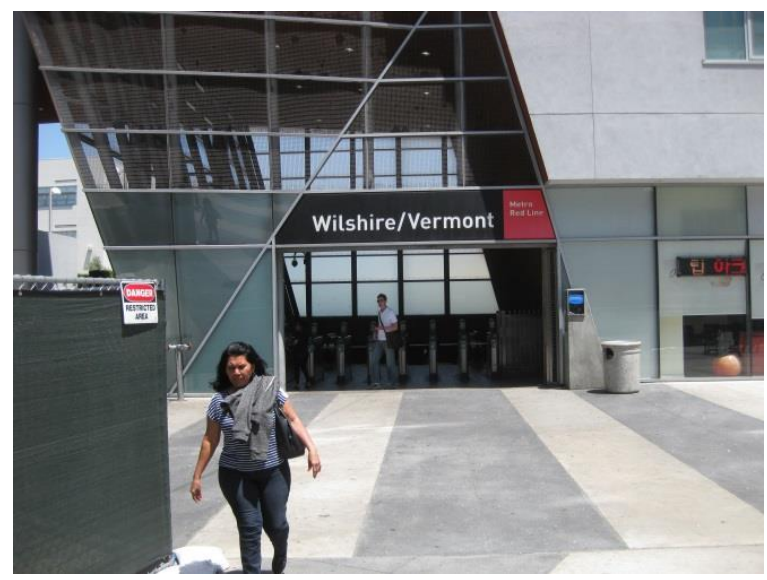

(c) Entrance to Metro station

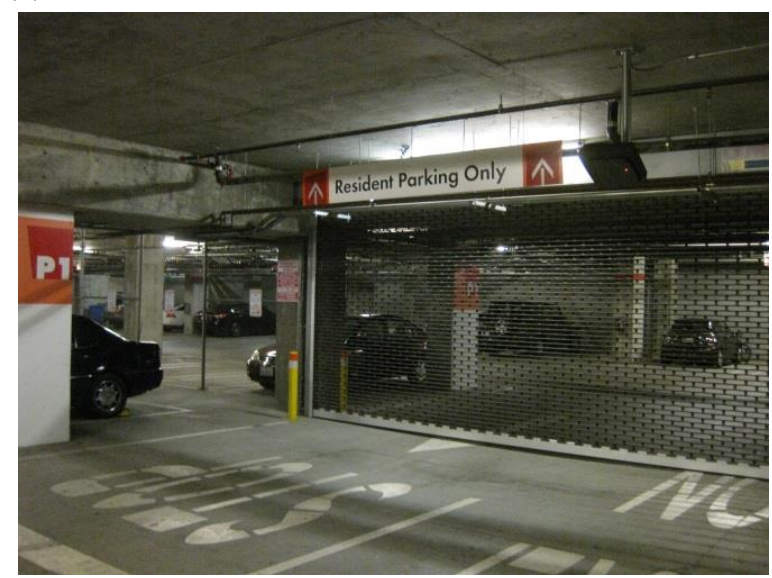

(e) Restricted access residential parking

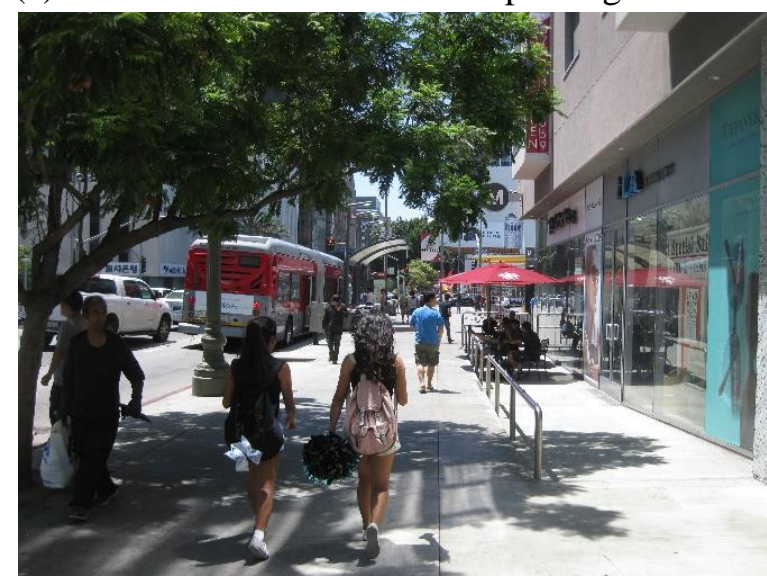

(g) Wilshire Boulevard with bus service

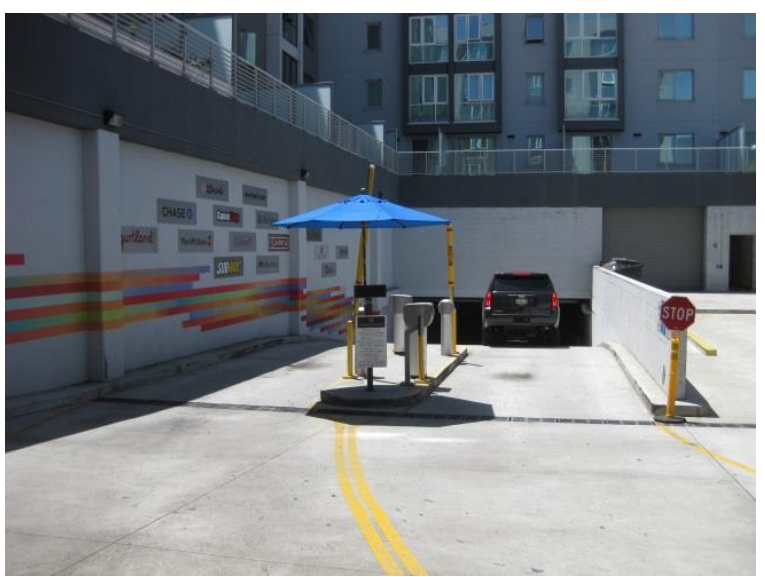

(d) Entrance to the parking garage

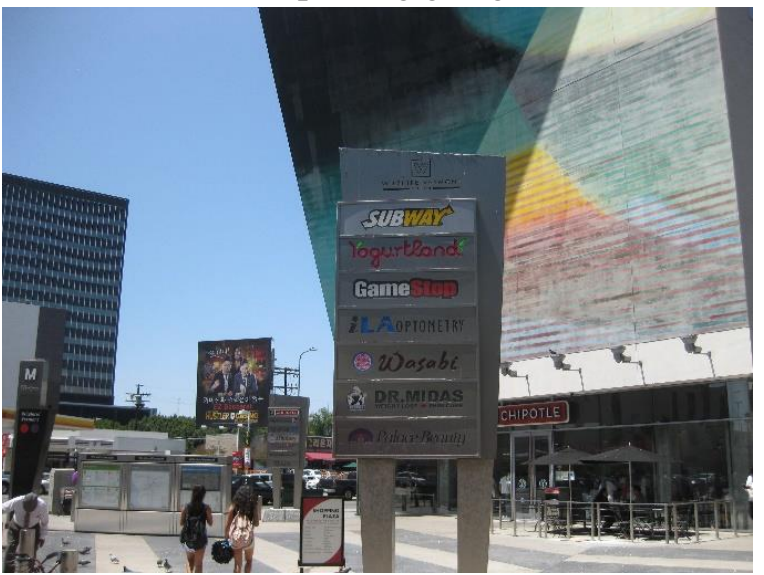

(f) Commercial uses

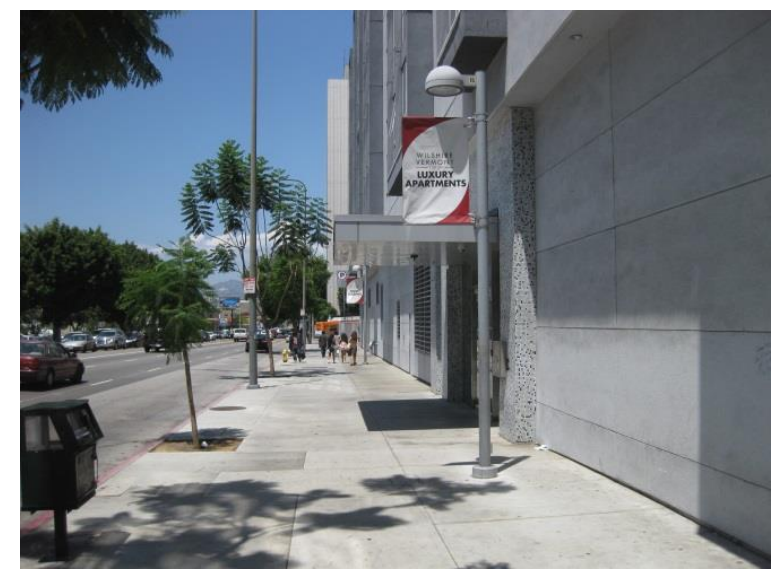

(h) Vermont Avenue residential entrance

\section{Figure 6.4. Wilshire/Vermont TOD}

\section{Data Collection}

The multimodal transportation planning and engineering firm of Fehr \& Peers developed a data collection plan and protocols, and managed data collection in the field and subsequent data entry for three types of travel data: (1) a full count of all persons entering and exiting the Wilshire/Vermont building, (2) a brief 
intercept survey of a sample of individuals entering and exiting the building, (3) parking inventory and occupancy counts of all off-street parking accessory to the commercial and residential uses of the building.

The intent of this approach was to develop an accurate measure of total trip generation associated with the commercial and residential space at the site, as well as a complementary sample of travel survey and parking utilization data that could be weighted by hour to provide a picture of the mode of travel, origin/destination, parking location- if applicable- and purpose for all trips to and from the building throughout the course of the day.

All survey and trip count data were recorded on location at Wilshire/Vermont TOD in Los Angeles, California, between 7:00 am and 9:00 pm on Tuesday, November 17, 2015. The survey and trip count data were performed by temporary staff in two shifts - a morning shift and an afternoon shift. We employed a total of 18 temporary staff (all of whom were planning or engineering students from the local universities - University of California, Los Angeles and University of Southern California) and four professional counting staff throughout the day. Professional counting staff were from National Data \& Surveying Services. Parking utilization was surveyed during this same period and was performed by two Fehr \& Peers staff. In addition, to determine parking occupancy during the anticipated period of peak utilization associated with the residential use, an "overnight" count of parking occupancy was conducted in the parking garage around midnight. Since the temporary staff were university students studying engineering and planning, they were very dedicated to the purpose of the project and determined to collect accurate data. The professional counting staff performed at a higher level with less supervision required.

For the purpose of counting person trips generated and recording travel patterns, separate teams of surveyors were employed to (a) count people entering/exiting at each building entrance, and (b) conduct intercept surveys. Fehr \& Peers planning staff supervised survey workers at building entrances. Surveyors were stationed on the public sidewalk in fixed positions where they could easily and continually observe all primary entrances to the building and the parking garage entrance (the second garage entrance was closed for construction). The only on-street parking available in the area was located to the east on Shatto Place. The on-street parking was 1-2 hour parking with a few being paid metered parking. From observations it didn't appear those on-street parking spaces were heavily utilized by Wilshire/Vermont users and therefore were not counted as part of this study. Instead, the on-street parking on Shatto Place was mainly utilized by the nearby Young Oak Kim Academy and businesses on the eastside.

Two surveyors (Fehr \& Peers staff) were full-time floaters and traveled amongst all the survey locations to ensure accuracy, answer questions, and to relieve the surveyors for periodic breaks. Care was taken to eliminate as much as possible the double counting of an individual that could occur from pedestrians entering/exiting the parking garage elevator located in the plaza of Wilshire/Vermont and then entering/exiting a commercial doorway. Residential users had direct elevator access from the parking garage to their residential units and therefore did not need to access to plaza area to enter the residential units. One surveyor (RC8 on Figure 6.5) was a designated floater whose responsibility it was to observe, to the best of his ability, all pedestrians accessing the parking garage elevator at the plaza level and then notify the respective counter of the doorway entered that they need not count that pedestrian (entering or exiting) since they were counted in their vehicle when entering/exiting the parking garage. 
All counters locations are illustrated in Figure 6.5. The surveyor (P1) on Shatto Place counted all vehicles entering/exiting the parking garage and the vehicle occupancy when visible. As noted previously, the second parking garage access located on Vermont Avenue was closed for construction. The other surveyors (RC1-RC7) recorded the number of pedestrians entering/exiting the commercial and residential doorways within the plaza, on Vermont Avenue and on Wilshire Boulevard.

It should be noted that even with all the care taken to eliminate over-counting, this most likely occurred when individuals entered and exited more than one commercial doorway on-site and during peak times when numerous pedestrians were exiting the parking garage elevator and couldn't be tracked to all the doorways. Although the number of metro users that park at Wilshire/Vermont is relatively low, there are some that do so. These metro-only users could also add to the over-counting because they were counted as vehicles entering/exiting the parking garage even though they may not have utilized any of the commercial uses on-site.

A separate team of surveyors - two all day - were employed to intercept and survey people entering and exiting the building. One surveyor was stationed in the plaza area while the other was stationed on the Wilshire Boulevard frontage. Both surveyors roamed the entire area as needed to capture individuals. Care was taken to not intercept the metro users who were traveling through (not stopping at any of the commercial uses on-site) the plaza between the metro rail station and the bus stop on Wilshire Boulevard. The surveyors covered all primary pedestrian entrances to the main building, but were instructed to leave their stations, as necessary to intercept and attempt to survey individuals seen moving toward an entrance, or away from a building exit.

As a first step, surveyors noted whether the subject was observed "coming" or "going" to/from the building, and the type and location of entrance/exit used, and recorded the time of intercept by checking a box on the data collection form associated with one of four 15-minute periods per hour.

People leaving the building were asked: (1) "How do you plan to get to your next destination?" (e.g. by what mode of travel?), and (2) What is the purpose of your trip? (e.g., "Going home," "Going to work," "Shopping," or "other").

People arriving at the building were asked: (1) "How did you get here?" (e.g. by what mode of travel?), and (2) What is the purpose of your trip? (e.g., "home-bound," "work-bound," "shopping," "workrelated," or "other").

Individuals who indicated that they had arrived, or would be leaving by automobile were also asked where they had parked their vehicle (i.e., "on-street", "in the garage", or "other").

Surveyors counted and attempted to intercept only those individuals observed walking to or from an entrance to the building. Individuals waiting for the train or bus, or walking between the rail station, bus stop and other trip origins/destinations not within Wilshire/Vermont were not counted or surveyed. 


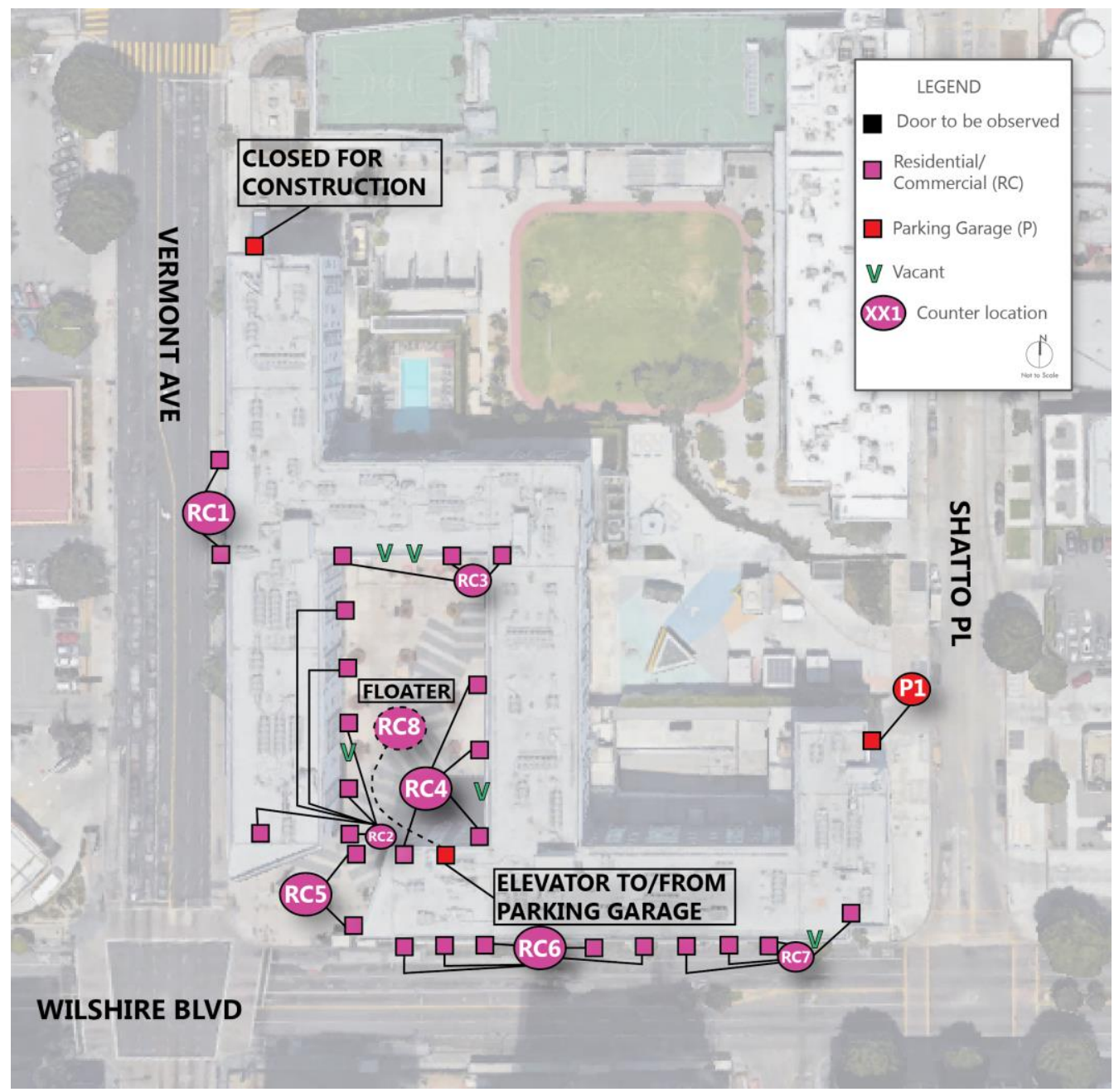

Figure 6.5. Wilshire/Vermont Counter and Survey Locations

\section{Mode Shares}

In the intercept survey, we had one surveyor at each entrance to the development to ask a sample of people questions. We received 516 valid surveys from 541 respondents. One question in the survey was what transportation mode was used to get to this development. The mode share from the intercept survey is presented in Table 6.3. We then applied this mode share to the total trip-generation counts by entrance to compute the final weighted mode share.

The final mode share for Wilshire/Vermont TOD is 27 percent walk, 2 percent bike, 21 percent bus, 20 percent rail, and 26 percent auto (see Table 6.3). According to the 2009 National Household Travel Survey, the Los Angeles--Riverside--Orange County region mode shares are 11.7 percent walk, 1 percent bike, 2 percent bus, 0.1 percent rail, and 84.4 percent auto. Compared with the regional mode shares, Wilshire/Vermont TOD has a significant mode shift from auto to walk, bike, and transit.

Wilshire/Vermont TOD has about 2.3 times the walk trips as the regional average, 2 times the bike trips, 10 times the percentage of bus trips, and 200 times the percentage of rail trips. 
Table 6.3. Mode Shares in Wilshire/Vermont TOD

\begin{tabular}{|l|r|r|r|r|r|r|r|r|}
\hline \multicolumn{2}{|c|}{ Entrance } & \multirow{2}{*}{ Count } & \multicolumn{7}{c|}{ Mode share (\%) } \\
\cline { 3 - 9 } & & Walk & Bike & Bus & Rail & Auto & \multicolumn{1}{c|}{ Other } \\
\hline Residential/Commercial & 436 & $36.93 \%$ & $2.98 \%$ & $28.44 \%$ & $27.06 \%$ & $0 *$ & $4.59 \%$ \\
\hline Parking Garage & 25 & 0 & 0 & 0 & 0 & 100 & 0 \\
\hline \multicolumn{7}{|c|}{ Trip generation counts } \\
\hline \multirow{2}{*}{ Entrance } & \multirow{2}{*}{ Count } & \multicolumn{7}{|c|}{ Count for modes } \\
\cline { 3 - 10 } & & Walk & Bike & Bus & Rail & Auto & Other \\
\hline Residential/Commercial & 8,179 & 3020 & 244 & 2326 & 2214 & 0 & 375 \\
\hline Parking Garage & 2,863 & & 0 & 0 & 0 & 0 & 2,863 & 0 \\
\hline Final mode share & 11,043 & $27.35 \%$ & $2.21 \%$ & $21.07 \%$ & $20.05 \%$ & $25.93 \%$ & $3.40 \%$ \\
\hline
\end{tabular}

*In fact, 80 people (15.50\%) intercepted on the plaza and appearing in the residential/commercial totals reported that they came or left by automobile. Because only a handful of people intercepted on the plaza were drop-offs, and none reportedly parked on the street, we believe that all of them were double counted. These are people who were counted when parking in the garage, then counted again on the plaza level. They have been subtracted out.

\section{Trip Generation}

Our actual trip-generation counts from the survey did not distinguish residential trips and commercial trips. To compare the actual trip generation with ITE's benchmarks, we combine all estimated trips for different uses into a total that can be compared to ITE.

There were an estimated 11,043 person trips and 2,218 vehicle trips observed the day of the survey. Those trips were generated by the 432 occupied residential units $\left(449^{*} 0.96\right)$ and 28,019 square feet of leased commercial space.

To determine the trip-generation rate of the residential building at Wilshire/Vermont TOD, we used the ITE Trip Generation Manual's value for "223 Mid-Rise Apartment," which is defined as "apartments (rental dwelling units) in rental buildings that have between three and 10 levels (floors)." The ITE manual reports a trip-generation rate for the peak hour but does not report a daily trip-generation rate for mid-rise apartments. However, the ITE manual reports the daily trip-generation rate for all apartments ("220 Apartments"). We used this rate to compute the daily trip-generation rate for mid-rise apartments. Here was the process: (1) the average daily vehicle trip-generation rate for "220 Apartments" is 6.65 per dwelling unit on a weekday, 0.55 per dwelling unit at the AM peak hour on a weekday, and 0.67 per dwelling unit at the PM peak hour on a weekday; (2) the average vehicle trip-generation rate for "223 Mid-Rise Apartment" is 0.35 per dwelling unit at the AM peak hour on a weekday and 0.44 per dwelling unit at the PM peak hour on a weekday; (3) the average daily vehicle trip-generation rate for " 223 MidRise Apartment” equals $6.65 *(0.35+0.44) /(0.55+0.67)$, which is 4.31 per dwelling unit.

To determine the trip-generation rate of the commercial uses at the Wilshire/Vermont TOD, we used the ITE Trip Generation Manual's values for "630 Clinic" for the clinic (Dr Midas Medical Clinic), "710 General Office Building" for the Los Angeles County Metropolitan Transportation Authority office (MTA Outpost), "715 Single Tenant Office Building” for the real estate agency (Shiloh), "720 Medical- 
Dental Office Building" for the optometry store (Ila Optometry), and "863 Electronic Superstore" for the mobile phone store (T-Mobile) and the videogame store (Gamestop).

"852 Convenience Market (Open 15-16 Hours)" is the ITE land use category for the convenience store (Metro Fresh) in Wilshire/Vermont. However, 852 Convenience Market (Open 15-16 Hours) does not provide a daily trip-generation rate. Therefore, we computed the daily trip-generation rate for convenience market (open 15-16 hours) as follows: (1) the average daily vehicle trip-generation rate for "851 Convenience Market (Open 24 Hours)" is 737.99 per 1,000 square feet on a weekday, 73.10 per 1,000 square feet in the AM peak hour on a weekday, and 53.42 per 1,000 square feet in the PM peak hour on a weekday; (2) the average vehicle trip-generation rate for " 852 Convenience Market (Open 1516 Hours)" is 32.60 per 1,000 square feet in the AM peak hour on a weekday and 36.22 per 1,000 square feet in the PM peak hour on a weekday; (3) the average daily vehicle trip-generation rate for " 852 Convenience Market (Open 15-16 Hours)" therefore equals $737.99 *((32.60+36.22) /(73.10+53.42))$, which is 401.43 per 1,000 square feet.

The "911 Walk-in Bank" is the ITE land use category for the bank (Chase Bank) in Wilshire/Vermont. However, 911 Walk-in Bank does not provide a daily trip-generation rate. Therefore, we computed the daily trip-generation rate for the walk-in bank as follows: (1) the average daily vehicle trip-generation rate for "912 Drive-in Bank" is 148.15 per 1,000 square feet on a weekday and the trip-generation rate for "912 Drive-in Bank" is 24.30 per 1,000 square feet in the hour between 4 and 6 pm of the peak hour adjacent street traffic vehicle trip on a weekday; (2) the trip-generation rate for "911 Walk-in Bank" is 12.13 per 1,000 square feet in the hour between 4 and $6 \mathrm{pm}$ of peak hour adjacent street traffic vehicle trip on a weekday; (3) the average daily vehicle trip-generation rate for "911 Walk-in Bank" therefore equals $148.15^{*}(12.13 / 24.30)$, which is 73.95 per 1,000 square feet.

We found that "918 Hair Salon" is the best analog for the beauty and nail stores (Palace Beauty and Onails) and that "920 Copy, Print and Express Ship Store" is the best analog for the express ship store (UPS) at Wilshire/Vermont. However, both 918 Hair Salon and 920 Copy, Print and Express Ship Store only provide weekday PM peak hour trip-generation rates, not daily rates. Therefore, we multiplied by 10 to convert from weekday PM peak hour to daily trip generation, 10 being the typical ratio of peak to daily.

932 High-turnover (Sit-Down) Restaurant trip-generation rate has conservatively been applied to two restaurants in Wilshire/Vermont (Chipotle Mexican Grill and Wasabi Japanese Noodle House). The daily trip-generation rate is 127.15 per 1,000 square feet on a weekday.

"933 Fast-Food Restaurant without Drive-Through Windows" is the ITE land use category for the fast food restaurant (Subway) and "936 Coffee/Donut Shop without Drive-Through Window" is the ITE land use category for the coffee shop (The Coffee Bean \& Tea Leaf) in Wilshire/Vermont. However, those two land uses do not provide daily trip-generation rates. Instead, they provide only weekday AM and PM peak hour trip-generation rates. Therefore, we multiplied the daily trip generation for 932 High-turnover (SitDown) Restaurant by ratios of 10 to get the daily trip generation for those two land uses as we have done previously. 
"933 Fast-Food Restaurant without Drive-Through Window" provides the best analog to the yogurt shop (Yogurtland) in Wilshire/Vermont. We multiplied by 10 to convert from weekday PM peak hour to daily trip-generation rates, 10 being the typical ratio of peak to daily.

Based on ITE's trip-generation rates, the Wilshire/Vermont TOD would be expected to generate 5,180 daily vehicle trips (Table 6.4). The actual number of vehicle trips we observed on the survey day was 2,228, which is 43 percent of ITE's expected value. This result is anomalous. Compared to Redmond TOD and Rhode Island Row TOD, Wilshire/Vermont TOD has a lower automobile mode share, but a higher vehicle trip-generation rate relative to ITE's estimate. How could this be? This is possible only if Wilshire/Vermont has a higher overall person trip-generation rate due to its urban setting and greater accessibility. It has long been speculated that urban developments might have higher trip-generation rates (by all modes) than suburban developments. To our knowledge, this is the only second study to document this phenomenon (Steiner 1998).

Table 6.4. Comparison of Daily Vehicle Trip Generation between ITE Guideline and Wilshire/Vermont TOD

\begin{tabular}{|c|c|c|c|}
\hline & Trip generation rate & Total units & Total daily trips \\
\hline ITE Guideline & - & - & 5,180 \\
\hline 223 Mid-Rise Apartment & 4.31 & 432 & 1,862 \\
\hline 630 Clinic & 31.45 & 1,491 & 47 \\
\hline 710 General Office Building & 11.03 & 2,397 & 26 \\
\hline 715 Single Tenant Office Building & 11.65 & 1,150 & 13 \\
\hline 720 Medical-Dental Office Building & 36.13 & 1,371 & 50 \\
\hline $\begin{array}{l}852 \text { Convenience Market (Open 15-16 } \\
\text { Hours) }\end{array}$ & 401.43 & 1,699 & 682 \\
\hline 863 Electronics Superstore & 45.04 & 3,625 & 163 \\
\hline 911 Walk-in Bank & 73.95 & 4,059 & 300 \\
\hline 918 Hair Salon & 19.3 & 2,893 & 56 \\
\hline 920 Copy, Print and Express Ship Store & 66.3 & 1,025 & 68 \\
\hline $\begin{array}{l}932 \text { High-Turnover (Sit-Down) } \\
\text { Restaurant }\end{array}$ & 127.15 & 4,215 & 536 \\
\hline $\begin{array}{l}933 \text { Fast-Food Restaurant without Drive- } \\
\text { Through Window (Yogurt shop) }\end{array}$ & 186 & 1,269 & 236 \\
\hline $\begin{array}{l}933 \text { Fast-Food Restaurant without Drive- } \\
\text { Through Window }\end{array}$ & 463.13 & 1,200 & 556 \\
\hline $\begin{array}{l}936 \text { Coffee/Donut Shop without Drive- } \\
\text { Through Window }\end{array}$ & 359.71 & 1,625 & 585 \\
\hline Wilshire/Vermont TOD & - & - & 2,228 \\
\hline
\end{tabular}

\section{Parking Generation}

Parking supply and demand recorded for the Wilshire/Vermont TOD project are compared to the number of parking stalls as well as occupancy rates from the 2010 ITE Parking Generation manual.

\section{Residential}


For the residential component in the ITE Parking Generation manual, "222 High-Rise Apartment" (rental dwelling units) are defined as units located in rental buildings that have five or more levels (floors) and most likely have one or more elevators. This is the best match for the 6-story multifamily residential uses at the Wilshire/Vermont TOD. The average parking-supply ratio reported by ITE is 2.0 parking spaces per dwelling unit in a central city, but not downtown (CND). All study sites were within three blocks of transit service.

For the ITE land use category 222: High-Rise Apartment (CND), the average peak period parking demand from seven study sites is 1.37 vehicles per dwelling unit, with a standard deviation of 0.15 , a range of $1.51-1.52$, an $85^{\text {th }}$ percentile value of 1.52 , and a $33^{\text {rd }}$ percentile value of 1.38 . Besides the average rate, the ITE manual also provides the best-fit regression line for estimating total parked vehicles as a function of the total number of dwelling units:

$$
\mathrm{P}=1.04 \mathrm{x}+130
$$

Where $\mathrm{P}=$ parked vehicles and $\mathrm{x}=$ dwelling units

Wilshire/Vermont has a three-level parking garage, with parking for residents segregated from parking for retail customers and residential visitors. As shown in Table 6.5, actual parking supply for the residential units is 495 spaces, or 1.1 parking spaces per unit (495/449), which is only slightly more than half ITE's standard of 2.0 spaces per unit.

Demand for residential parking peaks around midnight. The number of occupied parking spaces at that hour is 349 , for a peak occupancy rate of 70.5 percent. The overall apartment occupancy rate is 96.2 percent (432 out of 449 units). Thus, peak residential parking demand relative to occupied units is $349 / 432$ or 0.81 spaces/unit. Actual demand (349 spaces) is much lower than both the ITE prediction of $592(1.37 * 432$, occupied units only) and the ITE regression estimate of $579(1.04 * 432+130$, occupied units only). Actual peak-period demand for residential parking at Wilshire/Vermont TOD is 59 percent $(100 * 349 / 592)$ of the ITE's predicted demand based on the average parking-generation rate, and 60 percent $(100 * 349 / 579)$ of ITE's average demand based on the regression equation.

\section{Commercial}

There is 37,021 square feet of leasable space for commercial uses at the Wilshire/Vermont TOD, of which 28,019 square feet were leased at the time of this study. Commercial users park in the garage in stalls shared with residential visitors. Peak demand for commercial parking falls in the late afternoon around 5:15 p.m. The number of occupied parking spaces at that hour is 76, for a peak occupancy rate of 107 percent. This is more than the parking supply because during the peak time businesses offer valet parking for customers, and the valets often double park or tandem park vehicles.

Table 6.5 lists commercial uses with parking in the garage and peak parking demands for the closest analog in the ITE Parking Generation manual. We found the most similar land use categories in the ITE Parking Generation manual for the following land uses in Wilshire/Vermont:

- “630: Clinic” (Dr. Midas Medical Clinic); 
- “701: Office Building” (the closest analogue to Shiloh, a real estate agency, and MTA Outpost, a Metro customer-service center);

- "720: Medical-Dental Office Building" (the closest analogue to the Ila Optometry);

- "851: Convenience Market (Open 24 Hours)" (the closest analog to Metro Fresh, the convenience store, although it is not open 24 hours);

- "863: Electronic Superstore" in an urban area (the closest analog to T-Mobile, a mobile phone store and Gamestop, a video game store);

- “920: Copy, Print and Express Ship” (UPS);

- “933: Fast-Food Restaurant without a Drive-Through Window” for Subway and Yogurt Land, non-hamburger restaurants.

The bank in Wilshire/Vermont (Chase Bank) is a walk-in bank. The ITE Parking Generation manual offers a parking-generation rate for drive-in banks, but not for walk-in banks. Notably, the ITE's Trip Generation Manual's entry for "911 Walk-in Bank" generates half as many vehicle trips as "912 Drive-in Bank." Therefore, we assume that the former needs half the parking supply and generates half the peak parking demand of the latter.

There is no entry for a hair salon in the ITE Parking Generation manual. Two of our lessees fall into that category (Palace Beauty and Onails). "701: Office Building" is the closest analog to hair salon in the ITE Parking Generation manual (it is not a very good analog, but it is the best we can do, and it has a tripgeneration rate that is very similar). For 701, the parking supply rate is four spaces per 1,000 square feet GFA and the weekday peak parking demand rate is 2.47 vehicles per 1,000 square feet GFA. We have multiplied those rates by 1.29 to get the rates for hair salon, 1.29 being the ratio of the trip-generation rate (in weekday PM peak hour of generator) for "918: Hair Salon" to "701: Office Building". So for hair salon, the parking supply rate is 5.18 spaces per 1,000 square feet GFA and the weekday peak parking demand rate is 3.18 vehicles per 1,000 square feet GFA.

Two of the restaurants in Wilshire/Vermont (Wasabi Japanese Noodle House and Chipotle Mexican Grill) fall into the category of "932: High-Turnover (Sit-Down) Restaurant without Bar or Lounge Facilities". The average parking-supply ratio at family restaurants is 14.3 spaces per 1,000 square feet GFA. The average peak period parking demand is 5.55 spaces per 1,000 square feet GFA during the weekday at an urban location with a standard deviation of 2.69, a range of 3.13-12.41, an $85^{\text {th }}$ percentile value of 6.37 , and a $33^{\text {rd }}$ percentile value of 3.86 .

One of the restaurants in the Wilshire/Vermont TOD (The Coffee Bean \& Tea Leaf) falls into the category of "936 Coffee/Donut Shop without Drive-Through Window." The average peak period demand for parking is 13.56 spaces per 1,000 square feet GFA during the weekday. However, the average parking-supply ratio is not provided. "936 Coffee/Donut Shop without Drive-Through Window" has 1.65 times as many average peak period parking demand as the "933 Fast-Food Restaurant without a DriveThrough Window." Therefore, we will assume that the former needs 1.65 times average parking supply of the latter.

According to the ITE manual, the parking supply for these commercial uses should be 213 spaces $(6.4 * 1.491+4.0 *(1.15+2.397)+4.0 * 1.371+5.7 * 1.699+2.3 *(1.476+2.149)+4.2 * 4.059+5.18 *(1.498+1.395)$ $+8.1 * 1.025+14.3 *(1.858+2.357)+12.7 *(1.269+1.2)+21 * 1.625)$. We cannot know precisely the actual 
parking supply for the leased commercial space alone, but based on the percentage of total floor area currently leased, it would be about 75.7 percent of the total number of parking stalls. This is to say, based on the current leases, about 54 stalls might be associated with the currently leased commercial space. This is only about 25 percent of the ITE parking supply guideline (as shown in Table 6.5).

According to the ITE guideline, the average total peak period parking demand for the leased commercial uses should be 119 spaces $(4.94 * 1.491+2.47 *(1.15+2.397)+3.2 * 1.371+3.11 * 1.699+1.91 *(1.476+2.149)$ $+2.0 * 4.059+3.18 *(1.498+1.395)+3.0 * 1.025+5.55 *(1.858+2.357)+8.2 *(1.269+1.2)+13.56 * 1.625)$.

Commercial users' actual peak demand for parking at Wilshire/Vermont TOD was 76 vehicles on the survey day, which is 64 percent of the ITE peak parking demand estimate.

Table 6.5. Comparison of Parking Supply and Demand Between Wilshire/Vermont TOD and ITE Guidelines

\begin{tabular}{|c|c|c|c|c|}
\hline \multicolumn{5}{|c|}{ Residential } \\
\hline & \multicolumn{2}{|c|}{ Supply } & \multicolumn{2}{|c|}{$\begin{array}{l}\text { Peak period demand } \\
\text { (occupied units only) }\end{array}$} \\
\hline & $\begin{array}{l}\text { Parking spaces per } \\
\text { unit }\end{array}$ & $\begin{array}{l}\text { Total parking } \\
\text { spaces }\end{array}$ & Vehicles per unit & \begin{tabular}{|l|} 
Total parked \\
vehicles
\end{tabular} \\
\hline $\begin{array}{l}\text { ITE guideline: } 222 \text { High- } \\
\text { Rise Apartment }\end{array}$ & 2.0 & 898 & 1.37 & 586 \\
\hline $\begin{array}{l}\text { Wilshire/Vermont TOD } \\
\text { residential }\end{array}$ & 1.10 & 495 & 0.81 & 349 \\
\hline \multicolumn{5}{|c|}{ Commercial (occupied space only) } \\
\hline & \multicolumn{2}{|c|}{ Supply } & \multicolumn{2}{|c|}{ Peak period demand } \\
\hline & $\begin{array}{l}\text { Parking spaces per } \\
1,000 \text { sq.ft. GFA }\end{array}$ & $\begin{array}{l}\text { Total parking } \\
\text { spaces }\end{array}$ & $\begin{array}{l}\text { Vehicles per unit or } \\
1,000 \text { sq. ft. GFA }\end{array}$ & $\begin{array}{l}\text { Total parked } \\
\text { vehicles }\end{array}$ \\
\hline ITE guideline & - & 213 & - & 119 \\
\hline 630 Clinic & 6.4 & 10 & 4.94 & 7 \\
\hline 701 Office Building & 4.0 & 14 & 2.47 & 9 \\
\hline $\begin{array}{l}720 \text { Medical-Dental Office } \\
\text { Building }\end{array}$ & 4.0 & 5 & 3.2 & 4 \\
\hline $\begin{array}{l}851 \text { Convenience Market } \\
\text { (Open 24 Hours) }\end{array}$ & 5.7 & 10 & 3.11 & 5 \\
\hline 863 Electronic Superstore & 2.3 & 8 & 1.91 & 7 \\
\hline 911 Walk-in Bank & 4.2 & 17 & 2.0 & 8 \\
\hline 918 Hair Salon & 5.18 & 15 & 3.18 & 9 \\
\hline $\begin{array}{l}920 \text { Copy, Print and } \\
\text { Express Ship Store }\end{array}$ & 8.1 & 8 & 3.0 & 3 \\
\hline $\begin{array}{l}932 \text { High-Turnover (Sit- } \\
\text { Down) Restaurant without } \\
\text { Bar or Lounge Facilities }\end{array}$ & 14.3 & 60 & 5.55 & 23 \\
\hline $\begin{array}{l}933 \text { Fast-Food Restaurant } \\
\text { without a Drive-Through } \\
\text { Window }\end{array}$ & 12.7 & 31 & 8.2 & 20 \\
\hline $\begin{array}{l}936 \text { Coffee/Donut Shop } \\
\text { without Drive-Through } \\
\text { Window } \\
\end{array}$ & 21.0 & 34 & 13.56 & 22 \\
\hline
\end{tabular}




\begin{tabular}{|c|c|c|c|c|}
\hline $\begin{array}{l}\text { Wilshire/Vermont TOD } \\
\text { commercial }\end{array}$ & - & 54 & - & $76^{*}$ \\
\hline \multicolumn{5}{|c|}{ Total } \\
\hline & \multicolumn{2}{|c|}{ Supply } & \multicolumn{2}{|c|}{ Peak period demand } \\
\hline ITE guideline & & 1,111 & \multicolumn{2}{|r|}{ NA** } \\
\hline Wilshire/Vermont TOD & & 549 & & $367 * * *$ \\
\hline
\end{tabular}

*This is more than the parking supply because businesses offer valet parking (i.e. double park, tandem park, etc.) during peak periods.

**Demand for residential and commercial parking peak during different periods. Therefore, we cannot simply sum them to get total peak parking demand.

***The most parked vehicles at the TOD for any one hour on the survey day.

In sum, the overall parking supply for the residential and occupied commercial space at Wilshire/Vermont TOD would be 1,111 stalls, according to the ITE guideline. Actual parking supply for all residential and occupied commercial space is 549 stalls, which is 49 percent of the ITE guideline. Actual peak parking demand for all residential and commercial uses at Wilshire/Vermont TOD was 367 occupied spaces at the hour of the survey day with the most parked cars. This is just 33 percent of the ITE supply guideline and 67 percent of the Wilshire/Vermont TOD's actual supply. We provide these last estimates to suggest what would be theoretically possible with shared residential and commercial parking.

\section{Parking Demands for Different Land Uses}

At Wilshire/Vermont TOD, there is no parking for Metro users. The parking garage has separate parking for residents and for public uses (retail and residential visitors). The parking demands for the development during the survey day are shown in Figure 6.6.

The occupancy rate for residential parking was about 60 percent in the morning. Then demand dropped during the day to less than 40 percent. Demand started to increase after 5 pm peaked at midnight. The peak occupancy rate was 70 percent.

For the public uses (retail and residential visitors), demand increased during the morning until the parking was fully occupied at about 2:00 p.m. Demand dropped after that to around 50 percent occupancy after 9:00 p.m. and 25 percent at midnight.

This finding clearly shows the benefit of sharing parking among different users at TODs. 


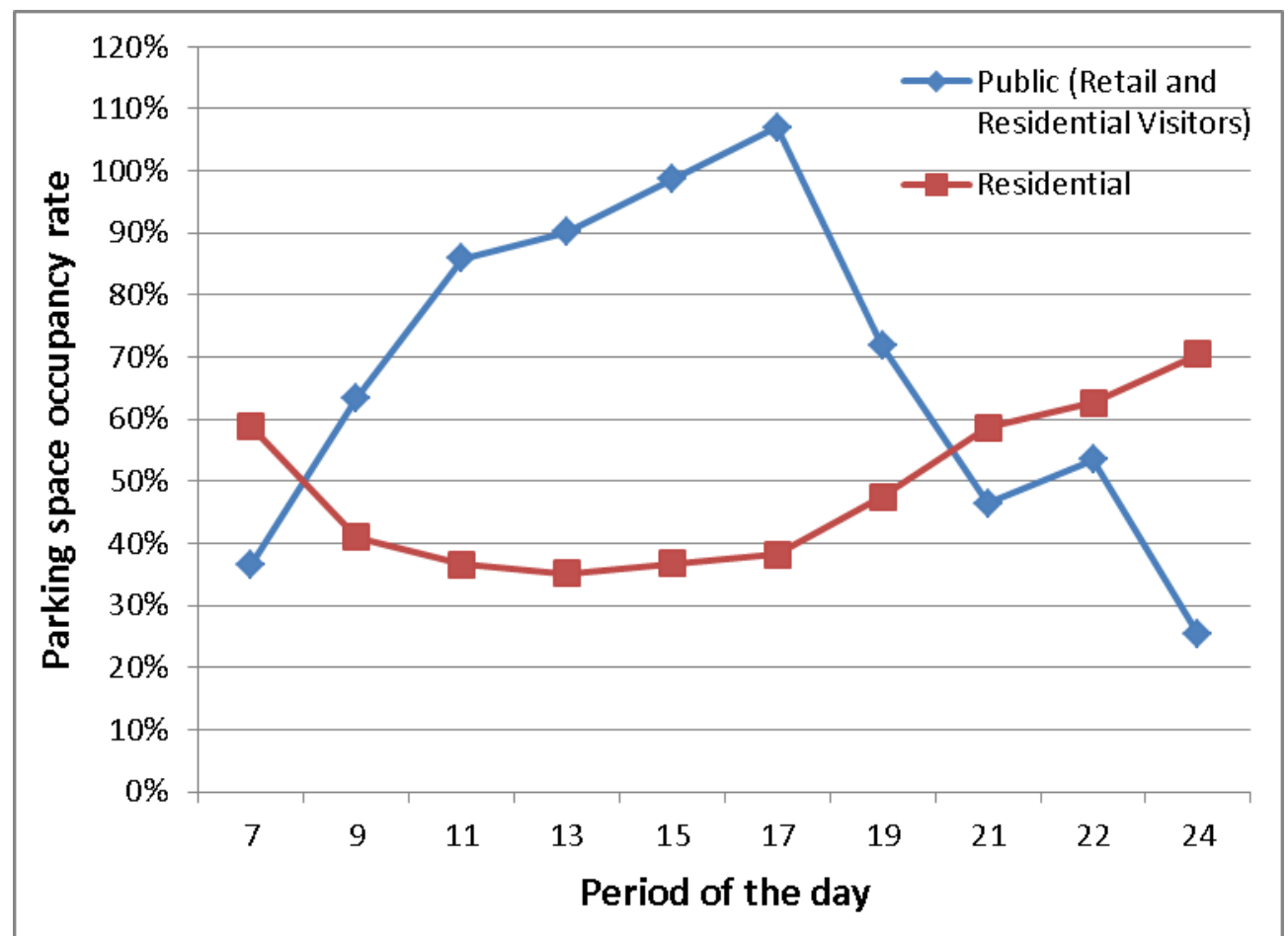

Figure 6.6. Parking Space Occupancy Rate for Different Uses at Wilshire/Vermont TOD

\section{Discussion}

The Wilshire/Vermont TOD is unique among the TODs studied. It is located in the most urban setting, only three miles from downtown Los Angeles. It is served by two heavy-rail subway lines and 13 bus lines provided by Metro, DASH, and Foothill Transit. The surrounding streets, Wilshire Boulevard and Vermont Avenue, are two of the busiest bus corridors in Los Angeles. Wilshire/Vermont TOD has the tallest building of the TODs studied: six stories of apartments above ground-floor commercial. And Wilshire/Vermont is the only TOD studied without a park-and-ride for transit users.

The urban setting of Wilshire/Vermont TOD is reflected in its mode shares. The TOD has a high walk mode share of 27 percent. At the same time, both the bus and rail mode shares are more than 20 percent. The combined mode share for transit is an impressive 41 percent. The bus mode share at this site is the highest among TODs studied. Like Fruitvale TOD, the high shares of active transportation leave little room for the automobile at Wilshire/Vermont TOD. The automobile mode share is only 26 percent, which is less than one third of Los Angeles' regional average of 84 percent.

Wilshire/Vermont TOD has a very low auto share, but not a commensurate reduction in vehicle trips. The actual number of vehicle trips we observed on the survey day was 43 percent of ITE's expected value. Compared to Redmond and Rhode Island Row, Wilshire/Vermont has a lower automobile mode share, but a higher vehicle trip-generation rate relative to ITE's estimates. This is possible only if Wilshire/Vermont has a higher overall person-trip generation rate, due to its urban setting and greater accessibility. The parking supply rates for both residential and commercial uses are lower than those suggested by ITE. The parking supply for commercial uses is only one third of ITE's guideline. The peak parking demand at the Wilshire/Vermont TOD is only 59 percent of ITE's average for residential use and 64 percent of ITE's average for commercial use. 


\section{Chapter 7: Conclusion}

As far as we can determine, this is the first study to estimate peak parking-generation rates for TODs, defined as dense, mixed-use developments proximate to high-quality transit. It is only the second study to estimate vehicle trip-generation rates for such developments. And it is one of the first to estimate mode shares for such developments. Summary statistics are shown in Tables 7.1 through 7.5. There is a certain logic or predictability to the summary statistics. See individual case study chapters for detailed information on how these summary statistics were derived.

\section{Mode Shares}

From Table 7.1, walk mode shares fall within a fairly narrow band, from 16.6 percent at Rhode Island Row to 28.3 percent at Fruitvale. They mostly reflect the environment in which the TOD is located, and secondarily the number of commercial trip attractions contained within the TOD. Wilshire/Vermont and Fruitvale are in the most urban settings. They have dense neighborhoods nearby and many commercial trip attractions on site. In contrast, Rhode Island Row and Englewood abut big-box retail development, which supports few if any walk trips. Redmond, which also has a relatively low walk mode share, has neighborhoods nearby that should generate walk trips, but also has the smallest number of commercial trip attractions of the TODs surveyed.

Bike mode shares are small for all TODs studied, although all but Rhode Island Row do exceed the national average for bike mode share. The mean bike mode share for this five-TOD study is only 2.5 percent. For planning purposes, it is safe to assume a small bike mode share for any planned TOD. It will not have much effect on overall vehicle trip and parking generation whether you assume a 1 percent bike mode share, the national average, or a 4 percent bike mode share, the highest for our five TODs. The bike mode share model of Tian et al. (2015) might be used to check whether the bike mode share assumed is, in fact, realistic.

Bus mode shares vary from a low of 3.3 percent at Englewood to a high of 21.1 percent at Wilshire/Vermont. All TODs studied, including Englewood, are served by multiple bus lines and have bus transfer operations adjacent to the TODs. All but bus-only Redmond TOD provide relatively seamless transfers from rail to bus and bus to rail. It is a matter of climbing off one vehicle, walking a very short distance, and climbing on another vehicle. The bus transfer area at Englewood is not nearly as amenityrich as at other TODs; there are no benches or shelters. At the other extreme, Wilshire/Vermont lies at the intersection of two major bus corridors. Density and related vehicle ownership may also have something to do with the contrasting mode shares. To the visitor, three-story Englewood reads very differently than seven-story Wilshire/Vermont; with ground floor retail both places, it is the difference between two stories of residential and six stories of residential.

Finally, rail transit proves its dominance over bus transit at three of the four locations where both are present. The exception is Wilshire/Vermont, where they have nearly identical mode shares. And, of course, there is no comparison for Redmond because it has only bus service. The smallest rail mode share is 13.6 percent at Englewood. The largest shares are 27.2 percent at Rhode Island Row and 26.1 percent at Fruitvale. Not surprisingly, these two TODs are located in Washington, D.C. and San Francisco, the regions with the best rail systems. In terms of ridership, Washington, D.C.'s Metro system ranks second 
in the U.S. behind New York City, while San Francisco's BART system ranks fifth. In terms of system route miles, they rank second and third in the United States, respectively.

Table 7.1. Average Mode Shares for TODs Studied

\begin{tabular}{|l|r|r|r|r|r|r|r|}
\hline \multirow{2}{*}{ TOD } & \multirow{2}{*}{ Count } & \multicolumn{6}{c|}{ Count for modes } \\
\cline { 5 - 9 } & & Walk & \multicolumn{1}{c|}{ Bike } & \multicolumn{1}{c|}{ Bus } & Rail & \multicolumn{1}{l|}{ Auto } & Other \\
\hline Redmond & 1,981 & $18.9 \%$ & $1.7 \%$ & $13.0 \%$ & $\mathrm{NA}$ & $64.9 \%$ & $1.5 \%$ \\
\hline Rhode Island Row & 8,451 & $16.6 \%$ & $0.3 \%$ & $9.3 \%$ & $27.2 \%$ & $42.5 \%$ & $4.0 \%$ \\
\hline Fruitvale & 16,558 & $28.3 \%$ & $4.3 \%$ & $15.2 \%$ & $26.1 \%$ & $23.0 \%$ & $3.1 \%$ \\
\hline Englewood & 14,073 & $19.2 \%$ & $3.8 \%$ & $3.3 \%$ & $13.6 \%$ & $59.7 \%$ & $0.2 \%$ \\
\hline Wilshire/Vermont & 11,043 & $27.4 \%$ & $2.2 \%$ & $21.1 \%$ & $20.1 \%$ & $25.9 \%$ & $3.4 \%$ \\
\hline Simple Averages & $\mathrm{NA}$ & $22.1 \%$ & $2.5 \%$ & $12.4 \%$ & $21.8 \%$ & $43.2 \%$ & $2.4 \%$ \\
\hline
\end{tabular}

\section{Vehicle Trip Generation}

Vehicle trip generation at the TODs in this study occurs at much lower rates than predicted by ITE guidelines. Table 7.2 shows that the number of vehicle trips at TODs range from one-third below to twothirds below ITE rates. The biggest reductions are at Rhode Island Row and Redmond, where the numbers of vehicle trips are, respectively, 34.7 and 37.4 percent of the number of trips predicted by the ITE Trip Generation Manual. These numbers represent a 65.3 percent reduction and a 62.6 percent reduction in vehicle trip-making relative to ITE's suburban, auto-oriented developments.

Similarly, vehicle trips at Wilshire/Vermont and Fruitvale are about half what is predicted by ITE. These are the most urban of the TODs in the sample. Off-site retail and housing options abound near both developments, and mode shares for walking are correspondingly high. Mode shares for transit use are also high, and auto mode shares are by far the lowest of the five TODs studied, a fact we will return to momentarily.

The smallest reduction is at Englewood. But even here, vehicle trips fall to 69.8 percent of the number predicted by ITE, a 30.2 percent reduction. That is, even in a relatively auto-oriented TOD like Englewood, with an abundance of free parking, vehicle trip reductions are substantial relative to the suburban norm.

Table 7.2. Average Vehicle Trip Reductions Relative to ITE Rates

\begin{tabular}{|l|r|r|r|r|}
\hline \multicolumn{1}{|c|}{ TOD } & $\begin{array}{c}\text { ITE vehicle } \\
\text { trips }\end{array}$ & $\begin{array}{c}\text { Actual vehicle } \\
\text { trips }\end{array}$ & \% of ITE trips & \% reduction \\
\hline Redmond & 1,767 & 661 & $37.4 \%$ & $62.6 \%$ \\
\hline Rhode Island Row & 5,808 & 2,017 & $34.7 \%$ & $65.3 \%$ \\
\hline Fruitvale & 5,899 & 3,056 & $51.8 \%$ & $48.2 \%$ \\
\hline Englewood & 13,544 & 9,460 & $69.8 \%$ & $30.2 \%$ \\
\hline Wilshire/Vermont & 5,180 & 2,228 & $43.0 \%$ & $57.0 \%$ \\
\hline
\end{tabular}


When the percentage of ITE vehicle trips from Table 7.2 is plotted again the percentage of automobile trips from Table 7.1, the resulting graph, Figure 7.1, has two interesting features. First, as one might expect, the percentages rise together in what appears, from certain data points, to be a linear manner from $(0,0)$ to $(100,100)$. If, as the ITE Trip Generation Manual itself says (see Chapter 1), the sites for which ITE trip-generation rates are calculated are overwhelmingly auto-oriented, then the upper right corner of the graph, where both variables are equal to 100 percent, represents the suburban norm captured by ITE. Conversely, the lower left corner, where both variables are equal to zero, represents a hypothetical development with no auto use at all (perhaps a rare Manhattan development). In such a development, there would likewise be no vehicle trip generation.

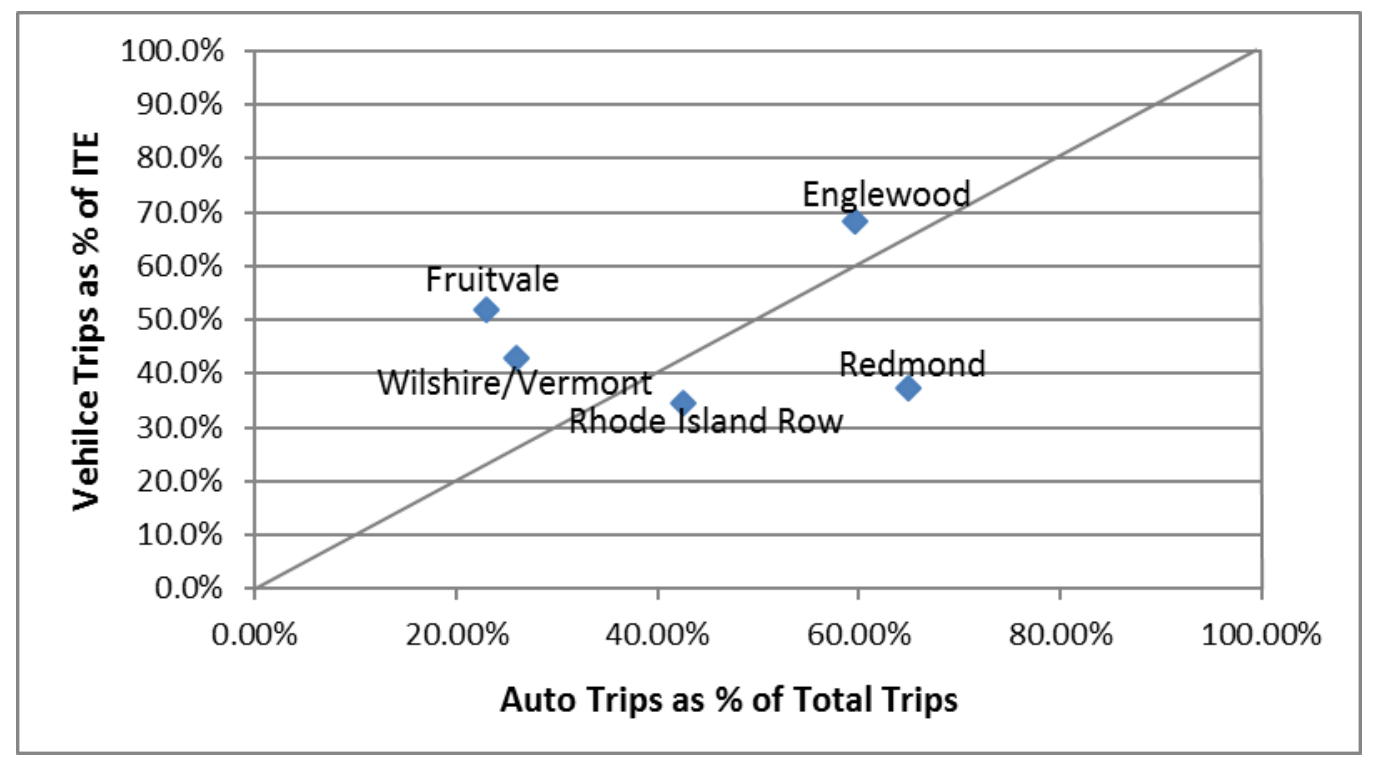

Figure 7.1. Vehicle Trip Generation vs. Auto Mode Share

But Figure 7.1 has another interesting feature. One of the data points, that of Fruitvale Village, lies well above the 45-degree line. This highly urban and commercial heavy site seems to generate more vehicle trips than it should, given its mode shares. Why would this be the case? One explanation, offered in Chapter 4, is that some trips within the development were double counted. People may have been counted entering or exiting one of the garages, then again on the plaza or sidewalk.

There is also another, more interesting, possibility. Development at Fruitvale, and to a lesser extent, Wilshire/Vermont, may be generating more person trips in total than their suburban counterparts, and hence more vehicle trips for any given mode split. Internal trips alone may boost the trip-generation rates of these two developments. People may have been counted entering or exiting one of the commercial establishments, and again exiting or entering another commercial establishment on an internal trip. They also may have been counted entering or exiting one of the "office" uses such as the library or the high school, and again exiting or entering one of the commercial establishments. Our on-site staff made particular note of students from the high school at Fruitvale patronizing the commercial establishments on their breaks.

It has long been speculated that urban developments might have higher trip-generation rates (by all modes) than their suburban counterparts due to the greater accessibility and hence lower generalized cost 
of travel at urban sites (Boarnet and Crane 2001). The practical implication is that one cannot simply apply ITE trip-generation rates to highly urban developments, then discount by a percentage for non-auto mode share. The policy implication is that these sorts of urban, transit-served developments may not produce as large a reduction in vehicle trips as a simple mode choice analysis would suggest (although, in terms of vehicle trip reduction relative to ITE rates, they still perform well).

Redmond TOD represents the opposite case. It is well below the 45-degree line in Figure 7.1. It has a high auto mode share, the highest in our sample of TODs, but the second lowest percentage of vehicle trips relative to ITE. Because ITE data represent trip generation in auto-oriented, suburban contexts, we would expect suburban Redmond TOD to have vehicle trip-generation rates very similar to ITE's, perhaps discounted by the percentage of walk and transit trips. We checked and double-checked the data provided by the consulting firm NelsonlNygaard and did not make an error in transferring it from their spreadsheets. Could vehicle trips have been undercounted by our consultant? It is possible but seems unlikely, given that lower volumes of people coming and going created fewer challenges for the counters at this site than at the other TODs. Could person-trip generation rates be lower at Redmond TOD than at the ITE sites, the reverse situation compared to Fruitvale? We speculated that Fruitvale's trip rates were higher than ITE's because of better accessibility. Could the accessibility at Redmond be worse than the ITE norm, and hence the overall person trip rates be lower? This also seems unlikely when comparing suburban development to suburban development. If anything, Redmond should be above the 45-degree line in Figure 7.1, albeit toward the upper right hand corner. We are left with no explanation for the anomalous Redmond results.

\section{Parking Generation}

Parking generation is much more complicated than vehicle trip generation. There is both supply of and demand for parking. There is residential, commercial, and mixed use parking. And, of course, there are ITE guidelines and actual parking numbers for our TOD sites. There are also issues such as shared parking between different land uses, bundled parking (guaranteed parking spaces as part of a rent payment) for residential uses, and paid parking for commercial uses. There are so many comparisons that could be made that we risk simply creating confusion, so we will try to keep it as simple as possible.

The bottom line of this section is clear. In almost all cases, the TODs in the sample supply much less parking than is called for in ITE guidelines. Despite these supply restrictions, demand for parking at TODs is well below the supply. That is to say, TODs are generally over-parked. But there are exceptions, as discussed below. Readers are referred to the individual case study chapters for more detailed discussions of parking supply and demand at the five TODs.

All of the featured TODs have apartments in multi-story buildings, so that is the land use category to which we compare TOD residential supplies to the ITE supply guideline. As noted in the individual chapters, supply is relatively easy to measure except where there is shared parking. In Redmond, Englewood, and Wilshire/Vermont, and in the south garage at Rhode Island Row, residential users have their own parking garages or lots, or have sections of garages reserved for them. Only in Fruitvale, and in the north garage at Rhode Island Row, is parking shared with commercial uses. Also, for computing supply per dwelling unit, we use the total number of residential parking spaces and the total number of apartments, not just the occupied apartments. The total number of apartments is easier to determine. 
In Table 7.3, we present supply numbers on a per dwelling unit basis (the common way of representing residential parking). The supply of parking stalls for residential use at TODs ranges from 0.81 stalls per dwelling unit at Rhode Island Row (57.9 percent of the ITE guideline) to 1.60 stalls per dwelling unit at Englewood (114.3 percent of the ITE guideline). Englewood actually provides more residential parking than ITE would suggest because of the agreement between the City of Englewood and the big-box retailer Wal-Mart, which was concerned that residential parking would spill over into the retailer's parking lot (see Chapter 6).

Now for a comparison of actual demand for residential parking at TODs to the supply at TODs. Peak demand for residential parking is trickier to estimate than parking supply. Unlike supply, we use only occupied apartments to compute the number of parking spaces per dwelling unit. We also make the assumption, where parking is shared, that residential parking demand peaks in the late night/early morning hours when apartment dwellers are presumably all at home, and commercial and transit users presumably have left. The peak demand for parking ranges from 0.44 spaces per occupied dwelling unit at Rhode Island Row (south garage) to 1.29 spaces per occupied dwelling unit at Englewood. From Table 7.3, the occupancy of residential parking spaces (peak demand divided by actual supply) ranges from 54.3 percent at Rhode Island Row (south garage) to 80.6 percent at Englewood.

Table 7.3. Residential Parking Supplies as a Percentage of ITE, and Residential Peak Parking Demand as a Percentage of Actual Supplies

\begin{tabular}{|l|r|r|r|r|r|}
\hline \multicolumn{1}{|c|}{ TOD } & $\begin{array}{c}\text { ITE supply } \\
\text { (spaces per } \\
\text { unit) }\end{array}$ & $\begin{array}{c}\text { TOD } \\
\text { supply } \\
\text { (spaces } \\
\text { per unit) }\end{array}$ & $\begin{array}{c}\text { TOD peak } \\
\text { demand } \\
\text { (occupied } \\
\text { spaces per } \\
\text { unit) }\end{array}$ & $\begin{array}{c}\text { TOD } \\
\text { supply } \\
\text { as \% of } \\
\text { ITE supply }\end{array}$ & $\begin{array}{c}\text { TOD peak } \\
\text { demand } \\
\text { as \% of } \\
\text { TOD supply }\end{array}$ \\
\hline Redmond & 2.0 & 1.19 & 0.86 & $59.5 \%$ & $72.3 \%$ \\
\hline Rhode Island Row & 1.4 & 0.81 & 0.44 & $57.9 \%$ & $54.3 \%$ \\
\hline Fruitvale & 1.4 & $\mathrm{NA}$ & 1.02 & $\mathrm{NA}$ & $\mathrm{NA}$ \\
\hline Englewood & 1.4 & 1.6 & 1.29 & $114.3 \%$ & $80.6 \%$ \\
\hline Wilshire/Vermont & 2.0 & 1.10 & 0.81 & $55.0 \%$ & $73.6 \%$ \\
\hline Average & 1.55 & 1.18 & 0.87 & $71.7 \%$ & $70.2 \%$ \\
\hline
\end{tabular}

Now on to commercial parking supplies and demands. As with residential parking, commercial parking supplies are well below ITE guidelines, but peak parking demand uses up most of the reduced parking supplies. For commercial parking, we can only report on aggregates, since parking is shared by the individual commercial uses in these multiuse projects. For Redmond, Englewood, and Wilshire/Vermont, commercial parking is separate from residential, and we can therefore compute statistics specific to commercial parking supply and demand. For parking supplies, we apply ITE supply rates to the specific square footage of leased commercial uses present within the development. For parking demand, we do the same with ITE peak demand rates (see individual case study chapters for examples). Unlike residential parking demand, which peaks at night, commercial parking demand peaks during the day.

For Rhode Island Row (north garage) and Fruitvale, commercial uses share parking with residential uses, and we can only compute statistics for the resulting mix of parking users. For mixed-use parking garages, 
we apply ITE supply rates to both residential and occupied commercial uses within the development. With residential parking, we assume that residential demand peaks in the early morning. For mixed uses, we use the actual daily peak parking volume (the one hour across the day when the number of parked cars is greatest) to represent the peak parking demand.

From Table 7.4, actual parking supplies for commercial and mixed-use garages and lots in our TODs range from 22.6 percent of ITE supplies at Fruitvale to 61.2 percent of ITE supplies at Englewood. These are huge reductions relative to ITE supplies. As noted in the Englewood case study, even relatively autooriented Englewood TOD conserves on parking.

With these reduced supplies, the TODs in our sample use most of their parking supplies during the peak hour. Peak demand for commercial/mixed-use parking garages and lots ranges from a low of 74.3 percent of parking supply at Englewood to 140.7 percent of supply at Wilshire/Vermont. Wilshire/Vermont is able to exceed the actual supply of parking spaces by using tandem, valet parking.

Table 7.4. Commercial/Mixed Use Parking Supplies as a Percentage of ITE, and Commercial/Mixed Use Peak Parking Demand as a Percentage of Actual Supplies

\begin{tabular}{|l|r|r|}
\hline \multicolumn{1}{|c|}{ TOD } & $\begin{array}{c}\text { Commercial/mixed use parking } \\
\text { supply as \% of ITE guideline }\end{array}$ & $\begin{array}{c}\text { Commercial/mixed use peak parking } \\
\text { demand as \% of actual supply }\end{array}$ \\
\hline Redmond & $27.5 \%$ & $85.7 \%$ \\
\hline Rhode Island Row & $50.8 \%$ & $78.9 \%$ \\
\hline Fruitvale & $22.6 \%$ & $84.0 \%$ \\
\hline Englewood & $61.2 \%$ & $74.3 \%$ \\
\hline Wilshire/Vermont & $25.4 \%$ & $140.7 \%$ \\
\hline
\end{tabular}

A final set of comparisons captures the potential of these exemplary developments to conserve on parking relative to ITE supply guidelines. This is the most extreme comparison, comparing peak demand for these mixed-use developments to supplies.

For this final comparison, we sum parking utilization across residential, commercial, and mixed-use parking areas for the hour when occupancy is at its highest for residential and commercial uses. We do not include transit park-and-ride parking in this comparison. At all TODs studied, transit users have their own garages or lots. The one exception is Englewood, where transit users share parking with commercial users in the civic center garage (see Chapter 6).

The first comparison (aggregate peak demand to aggregate actual supply) indicates the degree to which these developments are over-parked relative to their theoretical potential. From Table 7.5, at the overall peak hour, only 58.3 to 84.0 percent of parking spaces are filled. The latter is for Fruitvale, which has shared parking for residential and commercial uses. Due to limited shared parking, even these exemplary developments (except Fruitvale) do not achieve their full potential. This fact is discussed in the next section.

The second comparison (aggregate peak demand to aggregate ITE parking supplies) indicates just how wildly over-parked these developments would be if parking were built to ITE guidelines rather than 
scaled back for alternative mode use (walking and transit use). From Table 7.5, at the overall peak hour, parked cars would fill only 19.0 to 45.8 percent of parking spaces if built to ITE standards.

Table 7.5. Aggregate Parking Supplies as a Percentage of ITE Supplies, and Aggregate Peak Parking Demand as a Percentage of Actual Supplies

\begin{tabular}{|l|r|r|}
\hline \multicolumn{1}{|c|}{ TOD } & $\begin{array}{c}\text { Aggregate peak parking demand } \\
\text { as \% of ITE guideline }\end{array}$ & $\begin{array}{c}\text { Aggregate peak parking demand as \% } \\
\text { of actual supply }\end{array}$ \\
\hline Redmond & $41.6 \%$ & $73.5 \%$ \\
\hline Rhode Island Row & $32.7 \%$ & $63.6 \%$ \\
\hline Fruitvale & $19.0 \%$ & $84.0 \%$ \\
\hline Englewood & $45.8 \%$ & $58.3 \%$ \\
\hline Wilshire/Vermont & $33.0 \%$ & $66.8 \%$ \\
\hline
\end{tabular}

\section{Variables and Parking Policies}

Developments are often characterized in terms of D variables. The Ds all have an effect on travel demand (Ewing and Cervero 2010). The first three Ds - development density, land use diversity, and urban design - were coined by Cervero and Kockelman (1997). Two additional Ds — destination accessibility and distance to transit - were included in later research (Ewing and Cervero 2001; Ewing and Cervero 2010). Other Ds include demand management and demographics.

The five TODs studied in this project are more or less exemplary when it comes to the Ds. All contain a diverse land use mix, though Fruitvale could use more residential development and Redmond, in particular, could use more commercial development. All have public space and other pedestrian-friendly features, making them well-designed. All minimize distance to transit, literally abutting transit stations. Fruitvale and Rhode Island Row are served by two of the best rail systems in the nation, and thus have exemplary destination accessibility via transit. Wilshire/Vermont has exemplary bus accessibility as well. Several provide affordable housing, and thus attract the demographics most likely to use transit.

In terms of density, these developments (except Wilshire/Vermont) would be classified as low rise (five or fewer stories). The commercial floor area ratio is moderately high only at Fruitvale (see Table 1). Even density of residential development would be considered high only at Wilshire/Vermont and Redmond (see Table 1). The three-story development at Englewood, Fruitvale, and Rhode Island Row represent lost opportunities from a transit standpoint.

A sixth D, demand management (parking management), is mixed at the TODs studied. For one thing, there is a dearth of shared parking, though opportunities abound. Only Fruitvale and the north garage at Rhode Island Row share residential and commercial parking in the sense that the same spaces can be used at different hours by different users. In other cases, residential and commercial users may occupy the same garage, but with spaces reserved for one use or another (commercial at Redmond, residential at Wilshire/Vermont). And only Englewood shares parking between TOD and transit park-and-ride users. Again, they may share a garage as at Rhode Island Row, but spaces are reserved for transit park-and-ride users. At all surveyed developments, transit has its own, exclusive park-and-ride garage and/or lot. We 
are not implying that some reserved parking isn't warranted for marketing reasons, but the extent of reserved parking in these otherwise smart developments comes as a surprise.

Another area in which parking policies are not always smart is in bundled residential parking. A parking space/permit comes with each apartment in Englewood and Wilshire/Vermont, whether the renters want it and use it or not. Parking is effectively free. Fruitvale has a hybrid parking policy, where the first space/permit comes with the apartment. The second space (if renters want one) costs them $\$ 90$ per month. Very few renters opt for the second space, evidence that unbundled parking suppresses parking demand. Only in Redmond and Rhode Island Row is parking totally unbundled. In Redmond, reserved parking spaces are leased for $\$ 95$ per month (\$90 at the time of our study); and in Rhode Island Row, reserved parking spaces are leased for $\$ 150$ per month.

A third area in which parking policies are not always smart is in free commercial parking, the counterpart of bundled residential parking. Redmond and Englewood have free commercial parking. Of the other three, Rhode Island Row charges commercial parkers $\$ 2$ per hour or a maximum of $\$ 24$ per day (or $\$ 4.50$ for early birds). Comparable charges for Fruitvale Village are $\$ 3$ per hour and a maximum of $\$ 12.50$ per day; and for Wilshire/Vermont, the charge is $\$ 6$ per hour and a maximum of $\$ 30$ per day. All in all, except at Wilshire/Vermont, parking charges are modest.

In terms of parking policies, Englewood is the least progressive and has the highest vehicle trip generation rate relative to ITE. Imagine how much further parking supplies could be reduced if residential, commercial, and transit parking were shared, residential parking were unbundled, and commercial parking were on a pay basis.

\section{Study Limitations}

The limitations of this study are acknowledged elsewhere but summarized here. The first and most important is the small sample size. These are truly case studies, as opposed to a cross-sectional sample. Due to labor-intensiveness of data collection (two people at each entry point to a TOD, one to count and the other to survey), our sample is limited to five TODs. Only one of our TODs is exclusively bus-based, Redmond TOD. Only one is served by LRT, Englewood TOD. Only one is predominately commercial, Fruitvale (although Englewood has ample strip commercial along its southern boundary).

Related to this is limited external validity. External validity is the extent to which the results of a study can be generalized to other situations, in our case, to other TODs. In particular, these TODs are exemplary in that they meet the definitional criteria we established at the outset. In particular, the fact that they literally abut transit stations suggests that they represent the best case for TOD, except perhaps in a downtown setting. We discuss the application of our results to other TODs in the following section. Let it suffice to say that, unless a planned or proposed TOD shares essential characteristics with a TOD in our sample, generalization will be hazardous.

A third limitation is an inability to account for internal capture of trips within these TODs. Internal trips are trips that begin and end within a mixed-use development. Such trips obviously have much less impact on the environment and are generally subtracted from total trip-generation rates in traffic-impact studies. Our TODs are small and, we argue elsewhere, likely have low internal capture rates. It is hard to imagine, except perhaps at Englewood, anyone doing anything but walking within our sample of TODs. But as we 
expand our sample to larger TODs, we will want to ask a third question in our intercept surveys beyond the current two (those two being mode of travel and purpose of trip). We will want to ask whether the origin or destination is within the development.

A fourth limitation is related to the phenomenon of residential self-selection. Residential self-selection occurs when people who would use transit anyway elect to live in a TOD. The literature strongly suggests that not everyone living in a TOD does so for the transit connection. But many probably do. If there is ever a case where self-selection is likely to be powerful, it is at developments that offer immediate, highquality transit options. While the transportation statistics from these case studies can be used to plan individual TODs, which will likewise benefit from self-selection, these statistics probably (due to selfselection) overstate the benefit to the region as a whole in having TODs. Again, these self-selectors would be inclined to use transit anyway, so there is not as much impact on regional mode shares or vehicle trips or perhaps even parking demand as our statistics imply.

There are other limitations, such as the fact that our vehicle counts are typically from 7:00 in the morning until 9:00 at night, rather than the full 24 hours as with ITE. Another is that the seventh D variable, demographics, may be different for these TODs than others because most of the developments in our sample offer some affordable (as opposed to market rate) housing. But we still contend that this study has important practical planning implications, as discussed in the next section.

\section{Applications to TOD Planning}

How might the statistics in Tables 7.1 through 7.5 be used to plan for other TODs? Our statistics represent default values, to be used when better estimates are not available. If a TOD already exists and is, for example, being expanded (like Fruitvale's), planners would not use our default values but would want instead to conduct the same types of counts and intercept surveys we did to estimate the performance characteristics of the expanded TOD. The same idea would apply to new developments going in near existing TODs. Planners probably would want to conduct studies at those TODs to get the best possible estimates for new developments nearby. Redmond TOD and Rhode Island Row TOD, and their respective transit stations, have spawned nearby developments that may mirror the statistics of these particular TODs, perhaps with small adjustments since the new developments are not directly adjacent to the stations, as our sampled TODs are.

For planned TODs around other stations, in the same or other regions, our statistics may be used in tandem with regional travel model forecasts for a particular TOD or its respective traffic analysis zone. Regional travel models can capture the effects of transit service at a particular site, but typically do not capture the full effects of the D variables on travel demand. By D variables we mean development density, land use diversity, street design, destination accessibility, and distance to transit for a particular TOD. These are known to affect travel choices (Ewing and Cervero 2010; Ewing et al. 2010; Tian et al. 2015). On the other hand, our mode shares, trip generation rates, and parking generation rates are actual (not modeled) values that reflect all the D variables of particular TODs, but are particular to these developments and their contexts. Whether they apply to TODs with different $\mathrm{D}$ variables and different contexts will always be debatable. That is why we say that both modeled regional travel model forecasts and actual trip and parking generation rates for TODs should be considered in the planning of other TODs. 
One other source of travel data for mixed-use developments (MXDs) might be used to obtain independent estimates for TODs. For a sample of 412 MXDs in 13 diverse regions of the U.S., Tian et al. (2015) estimated models relating internal capture rates and external walk, bike, and transit mode shares to D variables for the developments and their surroundings. This study built on earlier research by Ewing et al. (2010). It would not be difficult to estimate these outcome variables for any given TOD. This would provide a "third" independent estimate of TOD travel characteristics around which to triangulate.

Perhaps conservatively, one could set a floor on alternative mode shares and percentages trip and parking reductions equal to the minimum values for our five TODs, or could set a cap on these equal to the maximums from this study. Also, one could look for the best match to a particular TOD being proposed from among our sample of TODs. As an example, a TOD proposed for a Salt Lake station area might be matched to Englewood TOD in Denver, since the metropolitan regions are most similar and both regions have LRT (light rail transit) rather than HRT (heavy rail transit). This would be particularly appropriate if the planned TOD were large and relatively auto-oriented, like Englewood TOD. Conversely, if the TOD were compact and pedestrian-oriented, largely commercial, and inclusive of affordable housing, one might match to Fruitvale Village, despite differences in rail systems (LRT vs. HRT) and metropolitan regions (Salt Lake City vs. San Francisco). Obviously, any application of these statistics would ideally involve triangulation in light of regional travel demand model forecasts and MXD model estimates.

The preceding discussion leads to a re-acknowledgement of the main limitation of this study, and a partial solution to the problem of finding an appropriate match for any new TOD that might be proposed. The only way to increase the external validity (generalizability) of this effort is to expand the sample of TODs studied, particularly including larger TODs with higher internal capture rates. In theory, at some point, we would have a sample of TODs large enough for statistical analysis. Trip and parking reductions relative to ITE could be modeled in terms of D variables for the TODs themselves, their contexts, and their type of transit service (HRT, LRT, CRT, streetcar, and bus only). However, given the high cost of the associated data collection efforts, we doubt our collective efforts will ever produce a statistical sample. So the best we can hope for is a mix of TODs that represents most of the common variations on the TOD theme. We think it particularly important that more LRT systems be represented in the sample, since these are systems that seem to be generating most of the TOD activity.

In this vein, we call for additional research on trip and parking generation at TODs. TODs, as we have defined them, are an increasingly common development type. In our home region of Salt Lake City alone, there are plans for nine TODs similar to those studied, including adjacency to rail stations. As of 2016, we are currently seeking funding to estimate trip and parking generation rates for two larger TODs on LRT systems, City Creek Center in Salt Lake City and Orenco Station in Portland. But creating a respectable sample of TODs with trip and parking data is too big a task to take on alone. 


\section{References}

Arrington, G.B., Cervero, R.: Effects of TOD on housing, parking, and travel (TCRP Report 128). Transportation Research Board, Washington, DC (2008)

Boarnet, M., Crane, R.: Travel by Design: The Influences of Urban Form on Travel. Oxford University Press, New York (2001)

Cervero, R.: Transit-based housing in California: evidence on ridership impacts. Transport Policy 1(3), 174-183 (1994)

Cervero, R., Adkins, A., Sullivan, C.: Are Suburban TODs Over-Parked? Journal of Public Transportation 13(2), 3 (2010)

Cervero, R., Arrington, G.B.: Vehicle trip reduction impacts of transit-oriented housing. Journal of Public Transportation 11(3), 1 (2008)

Cervero, R., Ferrell, C., Murphy, S.: Transit oriented development and joint development in the United States: A literature review. Transit Cooperative Research Program Research Results Digest, 52 (2002)

Cervero, R., Kockelman, K.: Travel demand and the 3Ds: density, diversity, and design. Transportation Research Part D: Transport and Environment 2(3), 199-219 (1997)

Cervero, R., Landis, J.: Twenty years of the Bay Area Rapid Transit system: Land use and development impacts. Transportation Research Part A: Policy and Practice 31(4), 309-333 (1997)

Cervero, R., Murphy, S., Ferrell, C., Goguts, N., Tsai, Y.: Transit-oriented development in the United States: Experiences, challenges, and prospects (Report No. 102) Transit Cooperative Research Program, Washington, DC (2004)

Chatman, D.G.: Does TOD need the T? On the importance of factors other than rail access. Journal of the American Planning Association 79(1), 17-31 (2013)

Dunphy, R., Cervero, R., Dock, F.C., NmcAvey, M., Porter, D.R., Swenson, C.J.: Developing Around Transit: Strategies and Solutions that Work. Urban Land Institute, Washington, DC (2004)

Edgar, S., Carr, C.R., Connors, M., Counts, D., Morrison, C., Priebe, J.: Best Practices For Addressing Access And Parking Needs Of Nonresident Users Of Rail And Intermodal Transportation Stations In Transit-Oriented Developments (No. NCHRP Project 20-68A, Scan 10-02) http://www.domesticscan.org/wp-content/uploads/NCHRP20-68A_10-02.pdf (2013). Accessed 23 June 2015

Ewing, R. Bartholomew, K.: Pedestrian- and transit-oriented design. Urban Land Institute, Washington, DC (2013)

Ewing, R., Cervero, R.: Travel and the built environment: a meta-analysis. Journal of the American planning association 76(3), 265-294 (2010)

Ewing, R., Cervero, R.: Travel and the built environment: a synthesis. Transportation Research Record: Journal of the Transportation Research Board 1780, 87-114 (2001)

Ewing, R., Greenwald, M., Zhang, M., Walters, J., Feldman, M., Cervero, R., ... \& Thomas, J.: Traffic generated by mixed-use developments - Six-region study using consistent built environmental measures. Journal of Urban Planning and Development 137(3), 248-261 (2010)

Faghri, A., Venigalla, M.: Measuring Travel Behavior and Transit Trip Generation Characteristics of Transit-Oriented Developments. Transportation Research Record: Journal of the Transportation Research Board 2397, $72-79$ (2013) 
Guo, Z.: Does residential parking supply affect household car ownership? The case of New York City.

Journal of Transport Geography 26, 18-28 (2013)

Handy, S., Shafizadeh, K., Schneider, R.: California Smart-Growth Trip Generation Rates Study. University of California, Davis for the California Department of Transportation. http://nacto.org/docs/usdg/smart_growth_trip_generation_rates_handy.pdf (2013). Accessed 23, June 2015

Institute of Transportation Engineers (ITE): Trip generation handbook, 2nd edition. ITE, Washington, DC (2004)

Institute of Transportation Engineers (ITE): Trip generation manual, 9th edition. ITE, Washington, DC (2012)

Institute of Transportation Engineers (ITE): Parking generation, 3rd edition. ITE, Washington, DC (2010)

Lund, H.M., Cervero, R., Wilson, R.W.: Travel characteristics of transit-oriented development in California. California Department of Transportation, Sacramento, CA (2004)

Lund, H.M., Willson, R., Cervero, R.: A re-evaluation of travel behavior in California TODs. Journal of Architectural and Planning Research 23(3), 247-263 (2006)

Martin, P., Hurrell, W.: Station Parking and Transit-Oriented Design: Transit Perspective. Transportation Research Record: Journal of the Transportation Research Board 2276, 110-115 (2012)

Puget Sound Regional Council (PSRC): PSRC'S 2014 Regional Travel Study: Key Comparisons Of 1999, 2006, And 2014 Travel Survey Findings. http://www.psrc.org/assets/12548/RegionalTravelSurveysComparison.pdf (2015). Accessed 23 June 2015

Reconnecting America: Briefing Report Number 3: Case Studies for Transit Oriented Development. Prepared for Local Initiatives Support Corporation Phoenix. http://www.instituteccd.org/uploads/iccd/documents/phoenix_3_tod.pdf (2009). Accessed 23 June 2015

Rogers, J., Emerine, D., Haas, P., Jackson, D., Kauffmann, P., Rybeck, R., Westrom, R.: Estimating Parking Utilization in Multi-Family Residential Buildings in Washington, DC. In Transportation Research Board 95th Annual Meeting, No. 164427 (2016)

Rowe, D., Bae, C. H., Shen, Q.: Evaluating the impact of transit service on parking demand and requirements. Transportation Research Record: Journal of the Transportation Research Board 2245, 56-62 (2011)

San Francisco Bay Area Metropolitan Transportation Commission (SFBAMTC): Characteristics of Rail and Ferry Station Area Residents in San Francisco Bay Area. http://www.mtc.ca.gov/planning/smart_growth/stars/Executive_Summary_BATS2000_Station_Area _Residents_Study.pdf (2006). Accessed 23 June 2015

Serafin, E., Swierk, R., Smith, Y., Meek, J.: A Parking Utilization Survey of Transit-Oriented Development Residential Properties in Santa Clara County. http://www.reconnectingamerica.org/assets/Uploads/VTA-TODParkingSurveyReport-VolI.pdf (2010). Accessed 1 March 2016

Tian, G., Ewing, R., White, A., Hamidi, S., Walters, J., Goates, J.P., Joyce, A.: Traffic Generated by Mixed-Use Developments-13-Region Study Using Consistent Built Environment Measures. Transportation Research Record: Journal of the Transportation Research Board 2500, 116-124 (2015)

Weinberger, R.: Death by a thousand curb-cuts: Evidence on the effect of minimum parking requirements on the choice to drive. Transport Policy 20, 93-102 (2012) 
Weinberger, R., Dock, S., Cohen, L., Rogers, J., Henson, J.: Predicting Travel Impacts of New Development in America's Major Cities: Testing Alternative Trip Generation Models, In Transportation Research Board 94th Annual Meeting (No. 15-4800) (2015)

Weinberger, R., Seaman, M., Johnson, C.: Residential off-street parking impacts on car ownership, vehicle miles traveled, and related carbon emissions: New York City case study. Transportation Research Record: Journal of the Transportation Research Board 2118, 24-30 (2009)

Willson, R.: Reading Between the regulations: Parking requirements, planners' perspectives, and transit. Journal of Public Transportation 3(1), 111-128 (2000)

Willson, R.: Parking policy for transit-oriented development: lessons for cities, transit agencies, and developers. Journal of Public Transportation 8(5): 5 (2005)

Willson, R., Menotti, V.: Commuter parking versus transit-oriented development: evaluation methodology. Transportation Research Record: Journal of the Transportation Research Board 2021, 118-125 (2007)

Zamir, K., Nasri, A., Baghaei, B., Mahapatra, S., Zhang, L.: Effects of Transit-Oriented Development on Trip Generation, Distribution, and Mode Share in Washington, DC, and Baltimore, Maryland. Transportation Research Record: Journal of the Transportation Research Board 2413, 45-53 (2014)

Zhang, M., Mulholland, K., Zhang, J., Gomez-Sanchez, A.J.: Getting the Parking Right for TransitOriented Development. Texas: Center for Transportation Research, University of Texas. http://swutc.tamu.edu/publications/technicalreports/161027-1.pdf (2012). Accessed 23, June 2015 